\title{
VIETNAM IN INTERNATIONAL INSTITUTIONS
}

By

Thi Binh Khong

\begin{abstract}
A thesis
submitted to the Victoria University of Wellington in fulfilment of the requirements for the degree of Doctor of Philosophy
\end{abstract}

Victoria University of Wellington

(2014) 


\begin{abstract}
This thesis investigates how socialization in three selected institutions, namely the Association of Southeast Asian Nations (ASEAN), the ASEAN Regional Forum (ARF) and the UN Security Council (UNSC) has led to pro-norm behaviour on the part of Vietnamese officials. This behavioural change was evidenced by their support for the creation of an ASEAN Human Rights Body, the adoption of Preventive Diplomacy Papers in the ARF and internalization of the Responsibility to Protect as an emerging norm at the Security Council. Empirical findings in the thesis show that socialization occurred across three case-studies, eliciting pro-norm behaviour on the part of state officials, though to varying degrees. These findings confirm the plausibility of socialization as a source of cooperative behaviour among state agents within social environments. In addition, they provide insights into the slow but increasingly active and substantive cooperation in political and security areas where Vietnam has historically been reluctant. The thesis concludes with a suggestion that socialization could be an extremely useful framework for investigating how far Vietnam might go beyond verbal support for new norms, given the country has recently embarked on a new phase of integration. Vietnam now attaches great importance to the implementation of international commitments that it has made, and considers this a guiding principle for the country's new integration strategy. Socialization processes could yield insights about the likely extent of norm internalization and compliance in this new period.
\end{abstract}




\section{TABLE OF CONTENTS}

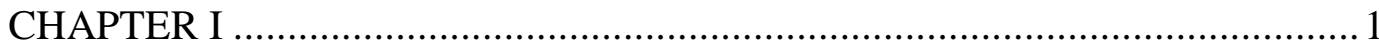

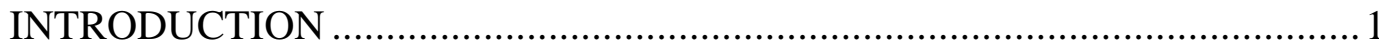

Background and research questions .................................................. 1

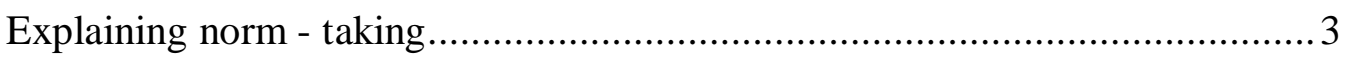

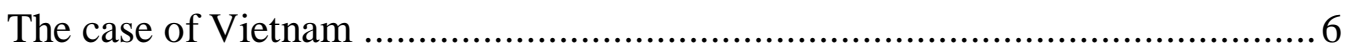

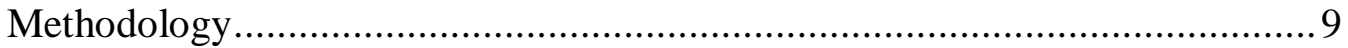

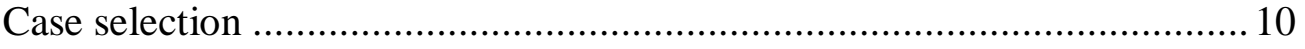

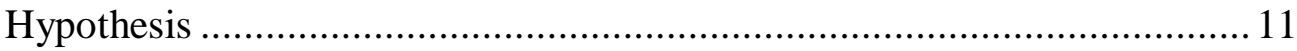

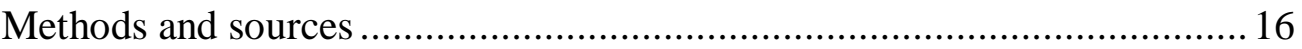

Structure of the thesis ..................................................................... 20

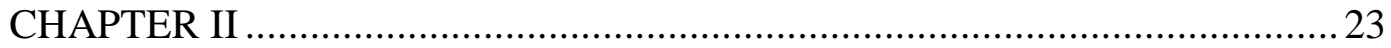

INSTITUTIONAL EFFECTS: A CONSTRUCTIVIST APPROACH ................23

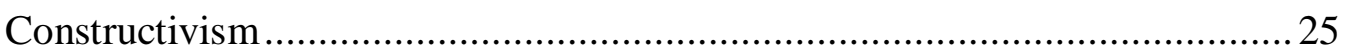

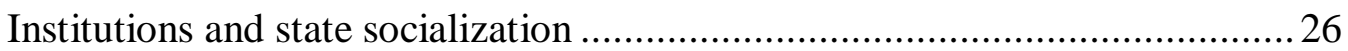

Socialization theory and the Asia-Pacific region......................................... 30

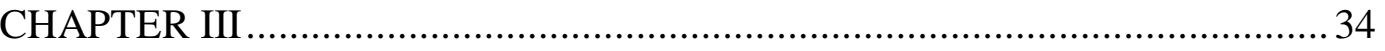

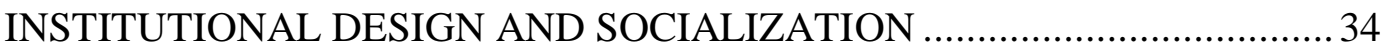

The Association of Southeast Asian Nations …............................................ 37

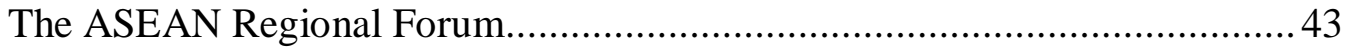

The United Nations Security Council ....................................................... 46

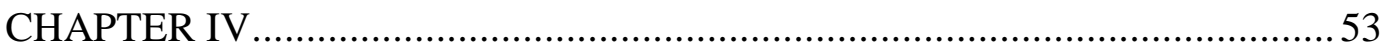

ASEAN AND THE CREATION OF A HUMAN RIGHTS BODY ..................53

ASEAN and the idea of a Human Rights Body ......................................... 54

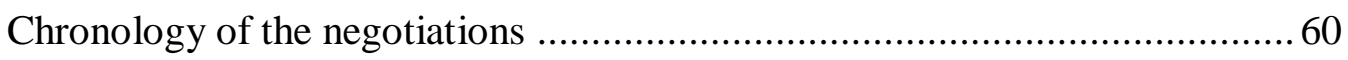

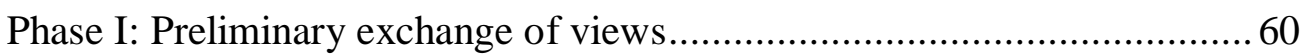

Phase II: Whether to establish an ASEAN Human Rights Body ................ 63 
Phase III: The TOR and functions of the HRB ......................................... 69

A balanced option reached .................................................................... 73

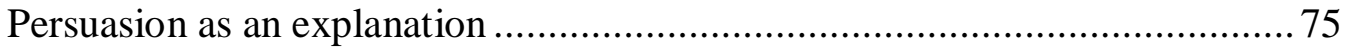

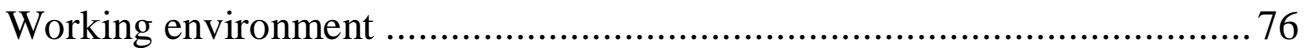

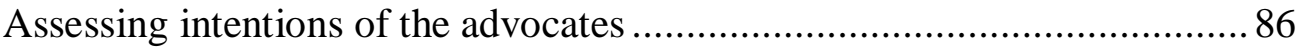

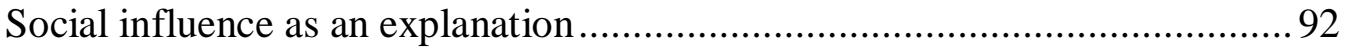

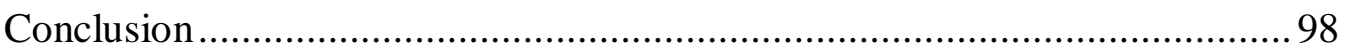

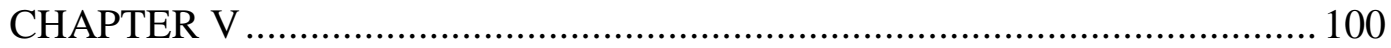

THE ASEAN REGIONAL FORUM AND PREVENTIVE DIPLOMACY ...... 100

PD deliberations and Vietnam's participation: A chronology ...................... 102

PD deliberations in inter-sessional year 1999-2000 ................................. 104

PD deliberations in inter-sessional year 2000-2001 ............................... 111

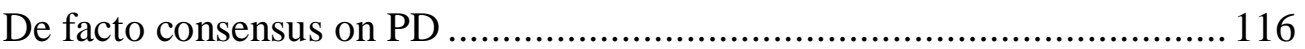

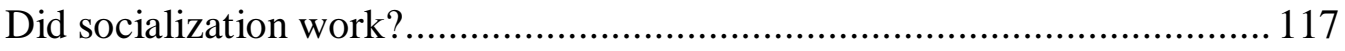

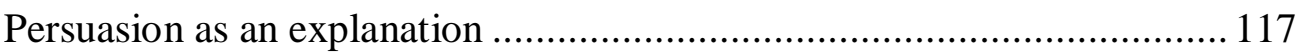

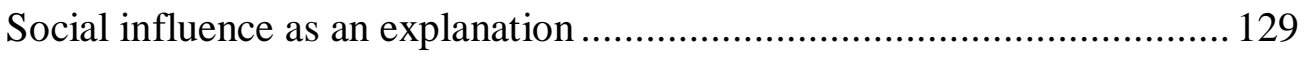

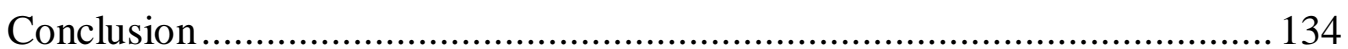

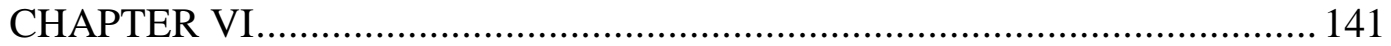

THE UNITED NATIONS SECURITY COUNCIL AND THE

RESPONSIBILITY TO PROTECT ....................................................... 141

The evolution of RtoP and Vietnam's position ........................................ 143

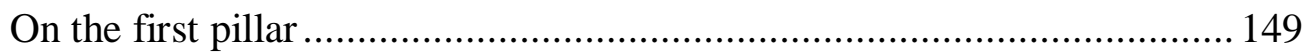

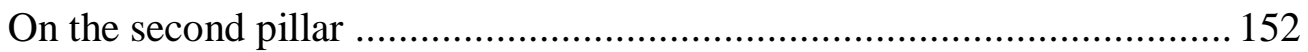

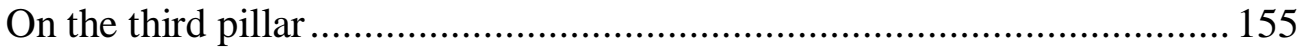

An increased comfort level with RtoP ............................................... 160

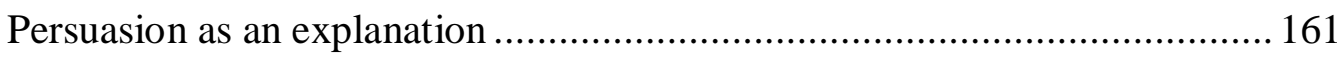

Attitudinal change as result of discussions on RtoP ................................. 164

Attitudinal change as result of involvement in possible RtoP situations .... 169

Social influence as an explanation ........................................................... 173

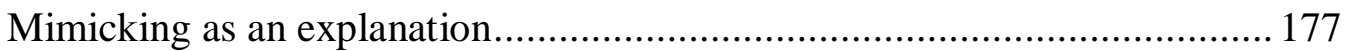

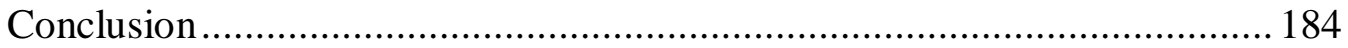




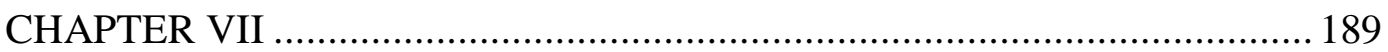

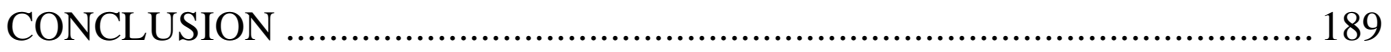

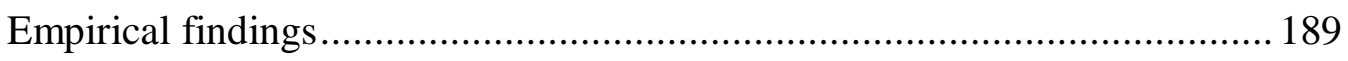

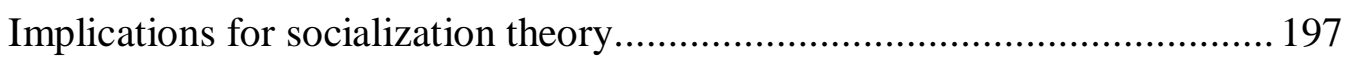

Beyond 2010: The new strategy of international integration ....................... 202

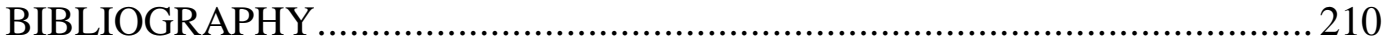




\section{ABBREVIATIONS}

\begin{tabular}{|c|c|}
\hline $\mathrm{ADB}$ & Asian Development Bank \\
\hline ADMM & ASEAN Defence Ministers Meeting \\
\hline APEC & Asia-Pacific Economic Forum \\
\hline $\mathrm{ARF}$ & ASEAN Regional Forum \\
\hline ARF ISG & ARF Inter-sessional Group \\
\hline ARF SOM & ARF Senior Officials Meeting \\
\hline ASC & ASEAN Standing Committee \\
\hline ASEAN & Association of Southeast Asian Nations \\
\hline ASEM & Asia-European Meeting \\
\hline ASO & Annual Security Outlook \\
\hline CBMs & Confidence Building Measures \\
\hline CLMV & Cambodia, Laos, Myanmar and Vietnam \\
\hline CPV & Communist Party of Vietnam \\
\hline CSCAP & Council for Security Cooperation in Asia-Pacific \\
\hline DAV & Diplomatic Academy of Vietnam \\
\hline EAS & East Asia Summit \\
\hline EU & European Union \\
\hline EEPs & Experts/Eminent Persons \\
\hline EPG & Eminent Persons Group \\
\hline HLTF & High Level Task Force \\
\hline HPA & Hanoi Plan of Action \\
\hline $\mathrm{HRB}$ & Human Rights Body \\
\hline \multirow[t]{2}{*}{ ICISS } & International Commission on Intervention and State \\
\hline & Sovereignty \\
\hline IMF & International Monetary Fund \\
\hline MOFA & Ministry of Foreign Affairs \\
\hline NAM & Non-Aligned Movement \\
\hline
\end{tabular}




$\begin{array}{ll}\text { NATO } & \text { North Atlantic Treaty Organization } \\ \text { PD } & \text { Preventive Diplomacy } \\ \text { PMC } & \text { Post Ministerial Conference } \\ \text { RtoP } & \text { Responsibility to Protect } \\ \text { TOR } & \text { Terms of Reference } \\ \text { UK } & \text { United Kingdom } \\ \text { UN } & \text { United Nations } \\ \text { UNESCO } & \text { United Nations Educational, Scientific and Cultural } \\ & \text { Organization } \\ \text { UNSC } & \text { United Nations Security Council } \\ \text { US } & \text { United States } \\ \text { VAP } & \text { Vientiane Action Program } \\ \text { WB } & \text { World Bank } \\ \text { WSOD } & \text { World Summit Outcome Document } \\ \text { WTO } & \text { World Trade Organization }\end{array}$




\section{ACKNOWLEDGEMENTS}

I feel deeply moved when writing these lines. What is still fresh in my mind today is the picture of a long railway that a professor used to illustrate the road that a $\mathrm{PhD}$ student has to travel to reach the destination. Now I have gone through such a long road and completed one important work in my academic career. On this occasion, I would like to express my sincere thanks to those that without their support and assistance this thesis would not have been completed.

First of all, I would like to express my deepest gratitude to the two supervisors, Associate Professor David Capie and Associate Professor Ben Thirkell-White for their careful supervision and warm encouragement throughout the study process. Discussions with David and Ben have been illuminating and I greatly benefited from their insightful and constructive comments and suggestions. More significantly, what I have learned from them is the way to conduct an independent research work that I believe the most important goal for those who want to become professional researchers.

For financial support, I am indebted to the Ministry of Education and Training of Vietnam and Victoria University of Wellington for providing me a joint-scholarship over the past four years. My special thanks also go to the Research Committee of the Faculty of Humanities and Social Sciences at Victoria. The Committee has provided me with large grants to conduct two field trips in Vietnam to collect data.

I would also like to thank many of my colleagues and friends at the Ministry of Foreign Affairs of Vietnam (MOFA) and the Diplomatic Academy of Vietnam (DAV) affiliated with it. My deepest appreciation goes to Dang Dinh Quy, Nguyen Vu Tung, Hoang Anh Tuan and Nguyen Hung Son who had encouraged me to pursue this challenging intellectual endeavour and provided me 
with enormous help while collecting data in Vietnam. Support from other colleagues and friends at MOFA in general and at the DAV in particular is also invaluable. Without their help I could not access the primary sources needed for the thesis. Also with these colleagues and friends I had open and insightful discussions on topics under examination.

The last words are for my family. I am deeply grateful to my parents who always support and encourage me. I am also grateful to my daughter, Hong Anh who came to New Zealand with me since the first day. I also owe an important debt to my husband for his support and assistance. Last but not least, I would like to thank my close friends, Tuyen Bui and her children who have been by my side over the past four years. Together, we make a big family and share unforgettable memories. 


\section{CHAPTER I}

\section{INTRODUCTION}

\section{Background and research questions}

Vietnam today is an increasingly active and important actor on the world stage. A major part of this new activism has been greater participation in regional and global institutions. ${ }^{1}$ While Vietnam's increased involvement in international institutions is not a wholly new phenomenon, ${ }^{2}$ the extent to which it has been affected by participation in these groups remains understudied. This thesis explores Vietnam's involvement in three important political and security institutions it joined in the post-Cold War period. In particular, it investigates if and how socialization inside these groups has changed Vietnam's behaviour to become more cooperative - a shift manifested in norm-taking - on some key political and security issues, where historically it has been reluctant to deepen cooperation.

The thesis is framed around the following questions: what did Vietnamese officials learn from participation in discussions and deliberations at these regional

\footnotetext{
${ }^{1}$ Phạm Gia Khiêm, "Ngoại giao Việt Nam năm 2010: Vững bước trên con đường hội nhập và phát triển" [Foreign affairs of Vietnam in 2010: Steady advance on the path of integration and development], Tạp chí Cộng sản 819 (2011):14-20; Phan Doãn Nam, "Ngoại giao Việt Nam trong 25 năm Đổi mới: 1986-2010" [Vietnam's diplomacy after 25 years of renovation, 1986-2010], Tạp chí Cộng sản 814 (2010): 42-6.

${ }^{2}$ Beginning with the normalization of relations with the International Monetary Fund (IMF), the World Bank (WB), the Asian Development Bank (ADB) in 1993 and especially its accession to ASEAN in 1995, in the 1990s Vietnam also joined other institutions such as the ASEAN Regional Forum (ARF), the Asia-Pacific Economic Cooperation (APEC) and the Asia-Europe Meeting (ASEM). The first decade of the 21st century has witnessed the country's further integration into the world community, gaining membership in the World Trade Organization (WTO) in 2006 and becoming a non-permanent member of the United Nations Security Council (UNSC) in 20082009. Vietnam is currently participating in the Trans-Pacific Partnership negotiations (TPP), a free trade area that composes of twelve members. This is in marked contrast with the limited involvement in institutional life in the period 1977-1991 when Vietnam only participated in the United Nations, some of its functional agencies, and the Non-Aligned Movement (NAM).
} 
and international institutions? Did socialization lead them to change their minds on issues and associated norms that they considered sensitive and with risks for the country's security and development, and if so, how? Did a change in their attitude lead to change in their preferences?

Up to now most scholarly works on Vietnam's participation in international institutions have focused on the costs and benefits of participation. Much less attention has been paid to if and how Vietnam has changed in the process. ${ }^{3}$ Of the work that is available, Vietnam's membership in the World Trade Organization (WTO) is the case that scholars claim has brought about the most extensive changes. In addition to technical changes such as legal and institutional reforms, ${ }^{4}$ Vietnam's integration into the WTO has arguably made an important contribution to "changing its old thinking, shaping and consolidating a new thinking on all fields." In particular, Vietnam now sees itself as an equal player in regional and global playing fields and admits that in that position it cannot act however it likes. ${ }^{6}$ Rather, it has to behave in conformity with common norms and rules if it is to maximize national interests. ${ }^{7}$

\footnotetext{
${ }^{3}$ The study of Vietnam's membership in ASEAN is a case in point. Many authors have explored the strategic, political, security and economic benefits as well as threats and challenges to Vietnam that has come about by participation in ASEAN. See for example, Carlyle A. Thayer, "Vietnamese Foreign Policy: Multilateralism and the Threat of Peaceful Evolution," in Vietnamese Foreign Policy in Transition, eds. Carlyle A. Thayer and Ramses Amer (Singapore: Institute of Southeast Asian Studies, 1999), 1-24; Ralf Amer, "The Indochinese Enlargement of ASEAN: Security Expectation and Outcomes," Australian Journal of International Affairs 59, no 1 (2005): 71-88; Jorn Dorsch, "Vietnam's ASEAN Membership Revisited: Golden Opportunity or Golden Cage?" Contemporary Southeast Asia 28, no. 2 (2006): 234-58; Carlyle A. Thayer, "Vietnam's Regional Integration: Domestic and External Challenges to State Sovereignty," in Vietnam's New Order: International Perspectives on the State and Reform in Vietnam, eds. Stephanie Balme and Mark Sidel (New York: Palgrave Macmilan, 2007), 31-50; David W.P. Elliott, Changing Worlds: Vietnam's Transition from Cold War to Globalization (New York: Oxford University Press, 2012), $150-52$.

${ }^{4}$ See Nguyễn Quang Thuấn, Năm năm Việt Nam gia nhập WTO [Vietnam's participation in the WTO in the first five years] (Ho Chi Minh City: Nhà xuất bản Khoa học Xã hội, 2013).

${ }^{5}$ Đặng Đình Quý, "Nhìn lại năm năm sau gia nhập WTO: Một số tác động về đối ngoại và bài học đối với Việt Nam" [Vietnam's participation in the WTO after five years: Implications and lessons for the country's external relations], Nghiên cúu Quốc tế 88 (2012): 8.

${ }^{6}$ Ibid.

${ }^{7}$ Ibid.
} 
While legal and institutional reforms are technical and conventional in the sense that they are obligations of any WTO member, Vietnam's recognition of the importance of norm-guided behaviour as part of its involvement in the WTO reflects a more fundamental change. On the one hand, Vietnam came to accept norms and rules and admitted that acting consistently with such norms and rules constitutes good behaviour. Put differently, what Vietnamese officials learned from participating in the WTO was that as a member Vietnam needed to act as norms and rules prescribe. On the other hand, such a change in perception occurred after Vietnamese officials directly engaged and dealt with other members in the WTO on a wide range of issues. Therefore, the recognition of and compliance with norms and rules is a perception change that came as a result of endogenous interactions inside the WTO.

Change in terms of norm acceptance on the part of Vietnam as a result of participation in the WTO thus raises an important issue: whether the same phenomenon also occurs in institutions other than the WTO and in issues other than economic and trade cooperation? This study seeks to identify and explain change in the form of norm-taking with a view to enriching the existing literature on how much Vietnam has changed as a result of participation in international institutions.

\section{Explaining norm - taking}

There are two possible explanations for an actor's approval of international norms. ${ }^{8}$ The first is a material approach which follows the logic of consequences and stresses that material side-payments and coercion motivate an

\footnotetext{
${ }^{8}$ On logics of social actions, see for example, Thomas Risse, "Constructivism and International Institutions: Toward Conversation across Paradigms," in Political Science: State of the Discipline, eds. Ira Katznelson and Helen V. Milner (New York: W. W. Norton \& Company, 2003), 600-4; Kjell Goldmann, "Appropriateness and Consequences: The Logic of Neo-Institutionalism," Governance 18, no. 1 (2005): 35-52.
} 
actor's decisions. In the materialist account, if an actor comes to accept certain norms inside international institutions, it does so in order to gain material rewards offered by the group or to avoid costs that might result from opposing them. Material incentives dominate neo-liberal explanations of international regime creation: states accept norms associated with the creation of regimes in order to pursue their given interests. In contrast, a second account advanced by constructivists follows the logic of arguing and of appropriateness. In this constructivist perspective, an actor adopts particular norms because they, through engaging and arguing with norm advocates, become convinced that such norms are correct or appropriate.

Constructivist accounts of norm adoption are fully captured in socialization theory developed by Alastair Iain Johnston. ${ }^{9}$ The theory assumes that even in the absence of exogenous material threats or promises, cooperation can be achieved through socialization. As Johnston observes, various definitions of socialization exist across the social sciences in general and political science in particular. Since these definitions share common themes, socialization can generally be understood as a process of social interaction through which novices or newcomers - be they individuals or states - learn to adopt, internalize and take for granted particular ways of thinking or acting, values, norms, attitudes or behaviour that are accepted, practised or upheld by the groups that they belong to. ${ }^{10}$ Specifically, socialization in the International Relations literature - from a constructivist perspective - refers to the process that new states, or those with limited participation in international life, come to adopt international norms. ${ }^{11}$

According to Johnston, the degree to which socialization works - how likely it is that an actor will come to adopt and internalize norms - depends on the

\footnotetext{
${ }^{9}$ Alastair Iain Johnston, "Treating International Institutions as Social Environments," International Studies Quarterly 45, no. 4 (2001): 487-515.

${ }^{10}$ Ibid., 494-6.

${ }^{11}$ Ibid.
} 
characteristics of the actor and the working environment of particular institutions. Of the former, Johnston argues that socialization effects will be most likely to happen if actors are newcomers whose noviceness is defined in terms of their (normally low) level of participation in institutional life. From this perspective, if actors are newcomers to an institution it will be much more likely for them to accept the norms embedded in that institution.

On the latter, Johnston suggests that institutional design matters in creating environments that are more conducive to socialization processes. This is because it is through these processes that a novice would engage in arguing, reasoning, interpreting or judging arguments conveyed by others upon a particular issue and associated norm. Johnston identifies three socialization processes, namely mimicking, social influence and persuasion. A more detailed analysis of what these processes are and how they work will be provided in chapter two. Here only a brief description of these mechanisms is provided: (i) mimicking is the act of copying behaviour of others in a group. This process happens when a novice actor enters an uncertain environment and in such a novel environment, that actor chooses to act like others in the group in order to survive; (ii) social influence is an indirect socialization process that arguably leads an actor to support the position advocated by the group through the distribution of social rewards or punishments; (iii) persuasion is a process that arguably leads to change in an actor's behaviour and preferences, thus creating common knowledge or a homogenization of interests. As such, persuasion is the key socialization mechanism. Johnston suggests that in order for these socialization processes to work, the most effective environments are those that are informal, weakly institutionalized and run on the basis of consensus. ${ }^{12}$

\footnotetext{
12 Ibid., 511.
} 
As a research program, socialization is at a nascent stage. There have been comparatively few works testing socialization theory in East Asia. ${ }^{13}$ As Johnston himself has pointed out, the study of institutions in Asia-Pacific should be a good focus for socialization research since a systematic study of institutions and socialization in this region has been "underdeveloped."14 Exploring Vietnam's involvement in international institutions since the end of the Cold War is one way to extend the empirical research on socialization. Although Vietnam has been seen by some as a potential target for socialization by the more established ASEAN members, it has not been used as a case to test socialization theory. ${ }^{15}$

\section{The case of Vietnam}

There are at least four reasons why socialization could be a useful explanatory framework in the case of Vietnam. First, the country is, to some degree, a novice and thus a target for socialization in the international institutions it has joined in the post-Cold War era. Although what constitutes a "novice" is not clearly defined, empirical research on the cases of China ${ }^{16}$ and ex-communist countries in Central and Eastern Europe ${ }^{17}$ implies that the concept has both quantitative and qualitative aspects. The quantitative aspect of noviceness is a state's overall level of participation in international institutions, while the qualitative aspect stresses differences in the way of thinking and acting between the targeted state and the communities that the state wishes to join.

\footnotetext{
${ }^{13}$ Alastair Iain Johnston, Social States: China in International Institutions, 1980-2000 (Princeton, N.J.: Princeton University Press, 2008); Alice D. Ba. "Who's Socializing Whom? Complex Engagement in Sino-ASEAN Relations," The Pacific Review 19, no. 2 (2006): 157-79.

14 Alastair Iain Johnston, "Conclusions and Extensions: Toward Mid-Range Theorizing and Beyond Europe," in International Institutions and Socialization in Europe, ed. Jeffrey T. Checkel (Cambridge University Press, 2007), 1037.

${ }^{15}$ See for example, Amitav Acharya, "Asian Regional Institutions and the Possibilities for Socializing the Behaviour of States" (Working Paper, Asian Development Bank, 2011); See Seng Tan, "Herding Cats: The Role of Persuasion in Political Change and Continuity in the Association of Southeast Asian Nations (ASEAN)," International Relations of the Asia-Pacific 13, no. 2 (2013): 233-65.

${ }^{16}$ Johnston, Social States.

${ }^{17}$ Jeffrey T. Checkel, ed., International Institutions and Socialization in Europe (Cambridge University Press, 2007).
} 
Vietnam's noviceness in a qualitative sense should be understood in the sense that the country is a new member acting in new institutional environments which cover novel issues and have different styles of communication and interactions, different language and norms. These institutions often include a diverse range of participants, including former rivals. ASEAN, the ASEAN Regional Forum and many other institutions are examples where Vietnam now sits along with states it formerly considered enemies. Taking into consideration both quantitative and qualitative aspects of noviceness, Vietnam is arguably a novice participant in post-Cold War international institutional life. It was clearly in new and challenging surroundings during the 1990s when it joined ASEAN, ARF, and APEC. Vietnam was also on unfamiliar ground when it joined the WTO and the United Nations Security Council in the first decade of the $21^{\text {st }}$ century. That said, there is no doubt that it has become more experienced as time has passed and as its overall participation rate has increased.

Second, Vietnam's perception of international integration has elements in common with Johnston's idea of socialization. For instance, in a recent review by a senior Vietnamese official, one of the prominent features of the first phase of the country's international integration was described as its participation in multilateral institutions that are associated with norm-taking. ${ }^{18}$ However, the review does not elaborate on which norms Vietnam has adopted as a result of participation in multilateral institutions, or how and why.

\footnotetext{
${ }^{18}$ Đặng Đình Quý, "Bàn thêm về khái niệm và nội hàm hội nhập quốc tế của Việt Nam trong giai đoạn mới" [On concepts and contents of Vietnam's international integration in the new period], Nghiên cúu Quốc tế 91 (2012): 26. In addition to norm-taking, the most recent Politburo Resolution on international integration released in April 2013 also stated that Vietnam should seriously implement its international commitments, be active in setting international rules and norms and effectively take advantage of such rules and norms. Integration in the Vietnamese perspective can therefore be described as a process of active acceptance and application of and participation in setting international rules and norms in a manner that would best serve its national interests. See "The Politburo Resolution no. 22-NQ/TW on International Integration," April 10, 2013, http://www.mofahcm.gov.vn/mofa/bng_vietnam/nr080212094156/ns130709211917.
} 
Third, there is a need to take into consideration both social and material factors in examining the process through which Vietnam has come to adopt international norms. Given that the country has experienced nearly two decades of involvement in institutional life, the level of interactions - engaging with others has increased accordingly. As a result, there is a possibility that in a certain context and depending upon a particular issue, decisions to adopt norms can be made because of peer pressure or pressure resulting from membership. This is where socialization theory, which accounts for norm-taking in the absence of material influences, can step in to make empirical research more insightful.

Finally, socialization theory is also relevant in the case of Vietnam because it suggests testing the effects of socialization on an actor's behaviour in security issues. ${ }^{19}$ In fact, Vietnam has long been reluctant to expand and substantiate cooperation in political and security issues. The country's integration process started with economic cooperation and gradually expanded to other areas. ${ }^{20}$ There were two main reasons for this: first, the domestic socio-economic crisis in the 1980s cried out for economic reform and integration; second, it was the Vietnamese leadership who had been heavily influenced by Marxism that determined that integration should start in economic field. ${ }^{21}$ It was not until the Xth National Congress of the Communist Party of Vietnam (CPV) in 2006 -

\footnotetext{
${ }^{19}$ Johnston, "Treating International Institutions as Social Environments," 509.

${ }^{20}$ On Vietnam's perception of integration, especially economic integration, see Nguyễn Vũ Tùng, ed., Chính sách Đối ngoại Việt Nam: 1975-2006 [Vietnamese foreign policy, 1975-2006] (Hanoi: Học viện Quan hệ Quốc tế, 2007), 220-63; Phạm Bình Minh, "Chủ động và tích cực hội nhập quốc tế theo tinh thần nghị quyết Đại hội Đảng toàn quốc lần thứ XI" [Proactive international integration in line with the Resolution of the XIth National Congress of the Communist Party of Vietnam], Nghiên cưu Quốc tế 91 (2012): 5-18.

${ }^{21}$ Despite the collapse of the socialist bloc in the Soviet Union and in Eastern Europe, Vietnamese leaders were persistent in taking the country toward socialism based on Marx's predictions on the transition toward socialism. See Elliott, Changing Worlds, 119-21; Documents adopted at the VIIth National Congress of the CPV in 1991, especially the section on economic reforms, incorporated various elements that were similar to those in Lenin's New Economic Policy (NEP). See "Documents of the VIIth National Congress of the Communist Party of Vietnam," the Communist Party of Vietnam, 1991, http://dangcongsan.vn/cpv/Modules/News/ListObjectNews.aspx?co_id=30145.
} 
twenty years after Doi Moi (Renovation) ${ }^{22}$ was launched - that expanding cooperation in other areas beyond economic integration was raised. Documents of the Xth Congress call for Vietnam to: "proactively and actively engage in international economic integration while expanding international cooperation in other fields." ${ }^{23}$ More recently, even prior to the XIth National Congress of the CPV in 2011, there was still opinion among some quarters that there should be no integration in political and security areas. ${ }^{24}$ Therefore, it is important to trace the development of Vietnam's thinking on cooperation in the previously closed areas. The Xth National Congress of the CPV in 2006 was significant in the sense that it marked a turning point and reflected a change in the perception of the Vietnamese leadership on the need to expand cooperation in other areas beyond economic and trade. This raises the question of why and how the Vietnamese leadership changed their minds to become more cooperative in areas where historically they have been reluctant. Socialization can help provide insights into important aspects of Vietnam's integration strategy.

\section{Methodology}

Having made the case that there are good reasons to study Vietnam's norm-taking inside international institutions, this next section discusses how specifically to examine the process through the lens of socialization. It starts with decisions about case selection with a view to testing socialization. The second part sets out the main hypothesis and the third section identifies the main research methods used, the sources required by using those methods and the structure of the thesis chapters that follow.

${ }^{22}$ Doi Moi (Renovation) is a comprehensive reform process officially launched at the VIth National Congress of the Communist Party of Vietnam in 1986. This grand strategy started with economic reform, aiming to help the country get out of the domestic socio-economic crisis and the external blockage and embargoes that Vietnam was subjected to throughout the 1980s.

23 "Documents of the Xth National Congress of the Communist Party of Vietnam," the Communist Party of Vietnam, accessed February 20, 2013, http://chinhphu.vn/portal/page/portal/ English

${ }^{24}$ Interview by author in Hanoi, March 25, 2013. 


\section{Case selection}

Which institutions should we look at if Vietnam is a good example to examine in the framework of socialization? Based on their importance in Vietnamese foreign policy and the suggestions of the socialization theory, the thesis looks at Vietnam's membership in the Association of Southeast Asian Nations (ASEAN), the ASEAN Regional Forum (ARF), and the United Nations Security Council (UNSC) as three main case studies. In relation to Vietnamese foreign policy, ASEAN, the ARF and the UNSC are among the most important institutions the country has joined since the end of the Cold War and they reflect Vietnam's involvement in institutional life at the sub-regional, regional and global levels. The importance of these three institutions is confirmed in the most recent Documents of the XIth National Congress of the CPV adopted in $2011 .^{25}$ One might also add Vietnam's membership in the WTO as another milestone in the country's foreign policy. However, the case of WTO membership is not chosen as a case study here since the organization deals with what are arguably lesssensitive issues of economics and trade. And as was noted above, since the highest priority in Vietnam's integration process is given to economic cooperation, this means the WTO is not a hard case for testing socialization: complying with the WTO's norms and rules is a means to reap the direct benefits afforded by membership. It might also be argued that the country's participation in security institutions such as the Nuclear Non-Proliferation Treaty (NPT) or the Comprehensive Test Ban Treaty (CTBT) could be cases worth studying. However, participation in these two institutions arguably came with very low costs for Vietnam. ${ }^{26}$

\footnotetext{
${ }^{25}$ Vietnam has made specific commitments on the fulfilment of obligations and showed determination to take on a new role as a proactive and responsible member, especially in ASEAN, regional security forums like the ARF, and the United Nations. The Documents of the XIth National Congress of the Communist Party of Vietnam can be accessed at http://chinhphu.vn.

${ }^{26}$ Vietnam signed the Comprehensive Nuclear-Test-Ban Treaty in 1996 and ratified this Treaty in 2006.
} 
In relation to socialization theory, ASEAN, the ARF, and the UNSC cover some of the key political and security issues which Vietnam has historically found challenging, thus providing an acid test for Vietnamese cooperation. For example, Vietnam's membership in ASEAN might impose policy constraints when it comes to reconciling hard-won sovereignty and regionalism. ${ }^{27}$ Similarly, one can argue that by participating in the UNSC, Vietnam only puts itself in a more difficult situation, because interactions with major powers, particularly the United States and China, could impose greater pressure.

In addition, these institutions vary in the extent to which they are institutionalized and they therefore allow us to consider institutional features as a factor that makes them conducive (or not) to socialization. Johnston suggests that the most effective environments for socializing actors are informal, weakly institutionalized and consensus-based institutions. On this basis, both ASEAN and the ARF would be the ideal cases to look for outcomes of socialization, since their institutional designs closely match Johnston's criteria. In contrast, the UNSC is strongly institutionalized. However, given this study is one of theory testing, the UNSC is chosen as a 'least-likely' case to test the effects of socialization in order to see if the theory is confirmed or not.

\section{Hypothesis}

As Johnston assumes, socialization leads an actor to support and internalize prevailing norms in institutions it joins. The thesis therefore starts with the hypothesis that socialization, particularly persuasion as a key socialization process, has occurred in the three selected institutions, leading Vietnam to support and internalize particular norms embedded in those institutions. In order to test this hypothesis, the following section will specify, in each of the institutions, the

27 Thayer, "Vietnam's Regional Integration: Domestic and External Challenges to State Sovereignty," 31-50. 
issue and associated norm that Vietnamese officials might have been persuaded by others to support.

\section{ASEAN}

ASEAN is a sub-regional institution in Southeast Asia. It was formed in 1967 with five founding members, including Indonesia, Malaysia, the Philippines, Singapore and Thailand. Enlargement occurred with the accession of Brunei in 1984 and then of a group of four states in the second half of the 1990s. Vietnam joined ASEAN in $1995 .{ }^{28}$ Over nearly two decades of participation, Vietnam has become more committed to the group: it makes an active contribution to the building of ASEAN into a Community and constructing a collective identity. One of Vietnam's most notable endeavours in deepening regional cooperation is its recent support for the creation of an ASEAN Human Rights Body (HRB), developing for the first time a shared perspective with other ASEAN members on one of the most controversial issues on the organization's agenda. The proposal was initiated in 1993 but it was not until 2007 when the ASEAN Charter was drafted that consensus was reached among ASEAN members to make it real. Vietnam's decision to support the creation of the HRB was significant because discussing human rights issues intra-regionally has long been considered a taboo in its foreign policy.

The drafting of the ASEAN Charter revealed sharp debates on whether a HRB should be established. The Task Force in charge of drafting the ASEAN Charter was split and their deliberations turned into a negotiation between two groups: participants from older ASEAN members who supported the initiative and those from newer members, namely Cambodia, Laos, Myanmar and Vietnam

\footnotetext{
${ }^{28}$ Laos and Myanmar entered ASEAN in 1997 and Cambodia in 1999.
} 
(CLMV) who were reluctant. ${ }^{29}$ However, the latter group finally agreed to the creation of the HRB. For the first time, Vietnam broke the taboo, agreeing to take on regional responsibility in this sensitive area. There are two possibilities for Vietnam's support of the HRB. Socialization theory would suggest that through discussions the Vietnamese representative found that arguments conveyed by representatives from older ASEAN members were persuasive and came to acknowledge that creating a HRB was a worthy common interest. Conversely, materialist theories would expect to see side-payments or coercion in order for Vietnam to go along with the initiative.

\section{$A R F$}

The ARF is a regional security forum formed in 1994 with a view to alleviating uncertainty caused by fundamental changes in the Asia-Pacific security environment after the end of Cold War. ${ }^{30}$ Vietnam was one of the first group of states to join the ARF in that year. A Concept Paper adopted in 1995 set out a three-stage process for the ARF's development: Stage I is on the promotion of confidence-building measures (CBMs); Stage II is on the development of preventive diplomacy mechanisms; and Stage III is on the development of conflict resolution mechanisms. ${ }^{31}$ Unlike ASEAN, the ARF as a process has not

\footnotetext{
${ }^{29}$ Tommy Koh, "The Negotiating Process," in The Making of the ASEAN Charter, eds. Tommy Koh, Rosario G. Manalo and Walter Woon (Singapore; Hackensack, NJ : World Scientific Pub. Co., 2009), 47-68.

${ }^{30}$ Khong Yuen Foong and Helen E.S. Nesadurai, "Hanging Together, Institutional Design, and Cooperation in Southeast Asia: AFTA and the ARF," in Crafting Cooperation: Regional International Institutions in Comparative Perspective, eds. Amitav Acharya and Alastair Iain Johnston (Cambridge; New York: Cambridge University Press, 2007), 58. On the formation and evolution of the ARF, see also Ralf Emmers, Cooperative Security and the Balance of Power in ASEAN and ARF (New York: Routledge Cruzon, 2003), 10-39; Alice D. Ba, (Re)Negotiating East and Southeast Asia: Region, Regionalism, and the Association of Southeast Asian Nations, (Stanford, Calif: Stanford University Press, 2009), 159-92; Rodolfo C. Severino, The ASEAN Regional Forum (Singapore: Institute of Southeast Asian Studies, 2009), 1-22; Noel M. Morada, "The ASEAN Regional Forum: Origins and Evolution," in Cooperative Security in the AsiaPacific: The ASEAN Regional Forum, eds. Jurgen Haacke and Noel M. Morada (London \& New York: Routledge, 2010), 13-35.

31 "The ASEAN Regional Forum: A Concept Paper," The ASEAN Regional Forum, August 1, 1995, http://aseanregionalforum.asean.org/files/library.
} 
experienced upheavals over the past decades. The institution has moved smoothly with Stage I and confidence-building measures, which are low-cost measures to adopt. Disagreement among members only began regarding the institution's embarkment on the second stage of preventive diplomacy (PD). Tracing the development of the ARF, deliberations on preventive diplomacy were most intense in the period 1997-2001. There were two broad groups of states in the ARF's PD deliberations. Vietnam was part of a reluctant group that also included China, Russia, India and almost all ASEAN members. Meanwhile, a group of activist members including Japan, the United States, Australia and Singapore pressed for the acceptance of PD. Deliberations between these two opposing groups eventually saw the reluctant side agree to the adoption of three documents in 2001, namely the Paper on Concepts and Principles of Preventive Diplomacy (PD paper), the Terms of Reference for the ARF Experts/Eminent Persons Register and the Paper on the Enhanced Role of the ARF Chair (hereinafter PD papers collectively). ${ }^{32}$ This seems a case where prima facie the argument could be made that Vietnam, as a reluctant member, was finally persuaded to go along with the adoption of PD papers, paving the way for the Forum to embark on the second stage of its development.

\section{UNSC}

Vietnam served a two-year term as a non-permanent member of the UNSC in 2008-2009. Unlike ASEAN and the ARF where Vietnam has participated for nearly two decades, the UNSC was a totally new environment. While many diverse international norms are debated at the UNSC, in 2008-2009 Vietnam found itself closely engaged with the Responsibility to Protect (RtoP) as a new emerging norm. The evolution of RtoP from an idea to a norm also met with strong opposition, especially from developing countries. Vietnam was no

\footnotetext{
32 "Chairman's Statement of the Eighth Meeting of the ASEAN Regional Forum," ASEAN Regional Forum, July 25, 2001, http://aseanregionalforum.asean.org/library/arf-chairmansstatements-and-reports.html.
} 
exception. Prior to the 2005 World Summit, Vietnam opposed RtoP. However, this position gradually changed: In 2005-2007, the country was described by one R2P advocate as a "fence-sitter" but by 2008-2009 had become "RtoPengaged.",33

Vietnam's support for RtoP was reaffirmed in various statements, stressing the primary role of states in protecting their people and the role of the international community, first and foremost the United Nations, in helping the countries concerned. If the Responsibility to Protect is just another expression of the old and controversial concept "humanitarian intervention", why and how did Vietnam come to adopt this norm while it still strongly upholds the nonintervention principle and opposes humanitarian intervention, especially military intervention? The possibility again is that through deliberations at the UNSC, Vietnamese officials came to a new understanding of RtoP, recognizing that it was not the same as humanitarian intervention and becoming convinced that it was appropriate and even needed in the world today.

In short, the thesis tests the hypothesis that persuasion has occurred in three selected institutions and that Vietnam came to support the group's position on the issues debated and associated norms. Did persuasion work in changing Vietnamese officials' attitude from opposing to supporting the creation of ASEAN HRB? Did it lead them to agree with the adoption of the Preventive Diplomacy Documents? Was persuasion the most plausible explanation for Vietnam's endorsement of RtoP? These questions will be answered in separate chapters in an effort to provide a full account of the events surrounding Vietnam's norm-taking behaviour.

\footnotetext{
${ }^{33}$ Alex J. Bellamy and Sara E. Davies, "The Responsibility to Protect in the Asia-Pacific Region," Security Dialogue 40, no. 6 (2009): 547-74.
} 


\section{Methods and sources}

\section{Methods}

Given the research design is one of theory-testing and its goal is to identify and assess evidence on the causal processes that might lead to changes in Vietnam's attitude and preferences on the above issues, the primary method used is process tracing. ${ }^{34}$ George and Bennett define process-tracing as a method that "attempts to identify the intervening causal process - the causal chain and causal mechanism - between an independent variable (or) variables and the outcome of the dependent variable." ${ }^{, 35}$ This method focuses on generating and assessing the evidence of the operation of hypothesized causal mechanisms within the confines of a case(s) under examination. ${ }^{36}$ The collected evidence thus allows analysts to judge whether the hypothesized explanation is adequate or not. More specifically, for case studies that may have a number of potential causes, tracing the processes that may have led to the expected outcome can help narrow the list of these possible causes by eliminating at least one or several rival explanations. For those cases with one main explanation, process tracing can help identify alternative causes that have led to the same outcomes. ${ }^{37}$

In the case of Vietnam, tracing the process of participation by state representatives, primarily diplomats, in the discussions and deliberations in ASEAN, the ARF and the UNSC will help collect evidence of the operation of

\footnotetext{
${ }^{34}$ On process tracing as a qualitative research method, see Alexander L. George and Andrew Bennett, Case Studies and Theory Development in the Social Sciences (Cambridge, Mass.: MIT Press, 2004), 205-32; Pascal Vennesson, "Case Studies and Process Tracing: Theories and Practices," in Approaches and Methodologies in the Social Sciences: a Pluralist Perspective, eds. Donatella Della Porta and Michael Keating (Cambridge: Cambridge University Press, 2008), 22339; Andrew Bennett, "Process Tracing: A Bayesian Perspective," in The Oxford Handbook of Political Methodology, eds. Janet M. Box-Steffensmeier, Henry E. Brady and David Collier, (Oxford; New York: Oxford University Press, 2008), 702-21; Jeffrey T. Checkel, "Process Tracing," in Qualitative Methods in International Relations: A Pluralist Guide, eds. Audie Klotz and Deepa Prakash (New York: Palgrave MacMillan, 2008), 114-30.

${ }^{35}$ George and Bennett, Case Studies and Theory Development in the Social Sciences, 205.

${ }^{36}$ Ibid., 214.

${ }^{37}$ Ibid., 207.
} 
persuasion as the primary hypothesized causal mechanism. In other words, it helps provide insights into if and how these state agents were persuaded to support the group's position on issues under examination. Given their involvement in the shaping of the country's foreign policy, tracing the process of participation by Vietnamese representatives in deliberations also sheds light on how their changed attitudes were reflected in policies on the issues debated in the selected institutions.

For the purpose of testing socialization theory, process-tracing evidence found in the Vietnam case not only helps test Johnston's assumptions about the causal micro-processes, but it may also reveal potential causes other than socialization that could have led to change in behaviour on the part of the state agents. In addition, close scrutiny of the Vietnamese experience provides insights into the conditions under which micro-socialization processes are more or less likely to occur, contributing to the improvement of the theory.

\section{Sources}

Since process tracing is the main method of this research, the key sources for this thesis are semi-structured interviews and documents analysis. The core group of interviewees include leaders in the Vietnamese Ministry of Foreign Affairs (MOFA) and senior officials and experts who either directly or indirectly were involved in the deliberations at the selected institutions. In particular, interviews were conducted with officials from the following MOFA Departments:

- ASEAN Department: This Department is in charge of activities at both ASEAN and the ARF. Semi-structured interviews were carried out with senior officials and experts who have participated in ASEAN and ARF activities, particularly those directly involved in the ARF's deliberations on Preventive Diplomacy in the late 1990s and early 2000s and in the drafting of the ASEAN Charter in 2007. 
- International Organizations Department: This Department is in charge of Vietnam's participation in international organizations, primarily at the global level such as the UN. Interviews focused on those in charge of the country's participation in UN activities in general and the UNSC in particular, especially officials who worked at the Mission in New York in the term 2008-2009.

- Foreign Policy Department: This Department is in charge of policy advising and planning, speech writing, coordinating with other departments and monitoring the implementation of Vietnamese foreign policy through different periods.

- West Asia and Africa Department: This department is in charge of Vietnam's relations with countries in these two geographical regions. Since the UNSC agenda in general and in the 2008-2009 period in particular covered various issues in African states, there has been close coordination between this Department and the International Organizations Department as well as with the Foreign Policy Department.

- Diplomatic Academy of Vietnam - MOFA's think tank: There is a small group of officials from the Academy who participate in ASEAN and ARF activities at both Track I and II. DAV has become more involved in the foreign policy making process and its voice now carries more weight than before.

- Other bodies: Officials from the Party's Central Committee for External Relations were also interviewed because this body also participates in the foreign policy making process.

Semi-structured interviews offer a number of advantages. First, they help provide background information of the issues debated. Second, they help open "behind-the-scenes" environments that officials are involved in and provide a better understanding of the characteristics of participants such as their initial preferences, beliefs and attitudes of the institutions and of other actors, and level of autonomy from their principals during deliberations. These are crucial factors in measuring how conducive to socialization the working environment in each institution is and which socialization process - mimicking, social influence or persuasion - is more likely to happen in such an environment. Third, interviews can help confirm the accuracy of information collected from various sources so as 
to determine which documents are more reliable. Of equal importance, interviews help determine how and to what extent officials' experience and knowledge gained from participation in international institutions - have been reflected in the formulation of particular policies.

Process tracing also requires collecting and reading archival documents. Those used in this study include the following:

- Primary sources: Unpublished documents such as MOFA department reports, talking points on specific issues, proposals and policy recommendations; reviews of Vietnam's participation in international institutions, particularly in ASEAN and the ARF which are normally made every five years, and assessment of the country's two-year term at the UNSC; and various research projects done by MOFA departments.

- Secondary sources: Published documents such as the Documents of the Vietnamese Communist Party (VCP) released at the Party Congress held every five years ${ }^{38}$ to review all aspects of the country's development over the previous five years and charting the orientation for the following five years. Other published sources include books and monographs. Books and journal articles on Vietnamese foreign policy are widely available both in Vietnamese and English and the two most relevant Vietnamese journals for this study are Tạp chí Cộng sản (the Communist Review) and Nghiên cứu Quốc tế (International Studies). The latter is a publication of the Diplomatic Academy of Vietnam.

Primary sources are of critical importance for this study. First, confidential documents are the most valuable sources that provide background information, helping build a detailed chronology of events under examination that may not be fully achieved only through interviews. Second, while the general orientation and guidelines of Vietnamese foreign policy can be found in published documents, its position and that of other concerned parties on particular issues can rarely be understood through these sources. Such information can only be acquired through accessing the primary sources and conducting in-depth interviews as mentioned

\footnotetext{
${ }^{38}$ The most recent is the XIth National Congress of the Communist Party of Vietnam which was held on January 12-19, 2011. Its Documents can be accessed at http://www.cpv.org.vn.
} 
above. In addition, published documents are not always suited to explaining processes of change.

Although there were some difficulties in conducting personal interviews and accessing archival materials, for example the mobility of Vietnamese diplomats with whom interviews were sought and the limited access to primary sources as provided by MOFA's working procedures, the author of this thesis is well-placed to conduct this study. Having worked for the Diplomatic Academy of Vietnam (DAV) for more than ten years, I have good contacts in the MOFA. Many of the interviewees are my colleagues. These people introduced me to higher ranking officials at the MOFA for interviews and material access, particularly confidential documents stored at relevant MOFA departments. Published documents can easily be found at the DAV Library because it is set up for MOFA research activities with unlimited access for research fellows and diplomats.

\section{Structure of the thesis}

The thesis is composed of seven chapters, including chapter one, which serves as an Introduction. Chapter two provides a review of the constructivist approach to institutional effects and state behaviour. Constructivism goes beyond neo-realism and neo-liberalism in showing how powerful institutions can be in influencing state actions. In a constructivist perspective, institutions do not only have regulative but also constitutive effects on states as actors. In particular, they play a significant role in socializing states to accept new norms and values.

Chapter three looks into the institutional design and features of ASEAN, the ARF, and the UNSC as the three selected institutions and the characteristics of the Vietnamese participants who were directly involved in deliberations and discussions at these institutions. The goal of this chapter is to measure the degree 
to which the different social environments are conducive to persuasion, as the main hypothesis to test the effects of socialization.

Chapters four, five and six constitute the main part of the thesis. Using the lens of socialization theory, these chapters investigate the most plausible explanation for Vietnam's changed attitude toward supporting the creation of the ASEAN HRB, the adoption of Preventive Diplomacy Papers, and its internalization of the Responsibility to Protect as an emerging norm, respectively. Each chapter seeks to identify the main socialization mechanism(s) that have led to this attitudinal change (and possibly changed preferences) in those key political and security issues.

These three chapters follow the same format. Each begins with an introduction which is in essence a brief summary of the chapter. This is followed by a detailed chronology of events or background of the issues debated, in which Vietnam's initial position and its changed attitude toward convergence with that of the group is highlighted. The third section starts by reminding the reader of the specific hypothesis and a brief analysis of how the working environment and the characteristics of the Vietnamese participants are conducive to socialization. It then relates a socialization account in changing the behaviour of Vietnamese participants on the issue examined. These accounts make up the heart of the three chapters.

Chapter seven - the conclusion - provides a brief summary of the main empirical findings and makes some generalizations on Vietnam's changed behaviour toward cooperation inside international institutions during the period covered by this study. I conclude there is some evidence that mimicking, social influence, and persuasion, individually or in combination, happened across the three case studies and exerted their social effects which led to the attitudinal change on the part of Vietnamese officials. Based on the available evidence, I 
argue that socialization can provide a plausible explanation for Vietnam's decisions to support the creation of ASEAN HRB, the adoption of the Preventive Diplomacy Documents and internalization of the Responsibility to Protect as a new international norm. Empirical findings in the case of Vietnam therefore support constructivists' claims about the significance of social factors in explaining the development of pro-norm behaviour among states. 


\section{CHAPTER II}

\section{INSTITUTIONAL EFFECTS: A CONSTRUCTIVIST APPROACH}

This chapter provides a review of the constructivist approach to studying how institutions influence state behaviour, especially with regard to the process through which states come to accept international norms. Why constructivism? It is because in both theoretical and empirical works constructivists go much further than neo-realists and neo-liberals in claiming significant institutional effects on state actions. For realists, the role of institutions in world politics is insignificant because they are the creation of self-interested states, thus being subjected to change and reform by their creators. ${ }^{39}$ As a result, institutions exert no independent effects on states. ${ }^{40}$ With regard to norm-taking, neo-realists argue that it is powerful states who set norms and rules and that "they would only agree to those norms and rules with which they can comply rather effortlessly."

Neo-liberals grant a greater role for institutions. In neo-liberal perspective, states create institutions to further their interests, but once formed institutions can constrain and shape state behaviour. Institutional effects can be grasped when one understands fundamental problems that institutions address. According to Keohane and Martin, these problems include coordination and the fear of cheating. ${ }^{42}$ Of the former, Stein argues institutions - in the form of multilateral

\footnotetext{
${ }^{39}$ John J. Mearsheimer, "The False Promise of International Institutions," International Security 19, no. 3 (1994-1995): 5-49; Kenneth N. Waltz, "Structure Realism after the Cold War," International Security 25, no. 1 (2000): 5-41.

${ }^{40}$ Institutions can at best work as intervening variables, but in a very restrictive circumstance. See Robert Jervis, "Security Regimes," in International Regimes, ed. Stephen D. Krasner (Ithaca: Cornell University Press, 1983), 173-94.

${ }^{41}$ Risse, "Constructivism and International Institutions: Toward Conversation across Paradigms," 616.

${ }^{42}$ Robert O. Keohane and Lisa L. Martin, "The Promise of Institutionalist Theory," International Security 20, no.1 (1995): 45.
} 
norms or conventions rather than strong formal organizations - help facilitate state cooperation through the provision of a focal point that allows actor expectations to converge upon one of the possible equilibria, serving as a basis for their cooperation. $^{43}$

Of the latter, Keohane believes that institutions can help in three distinctive ways. ${ }^{44}$ First, institutions work as monitoring mechanisms of state behaviour, creating and increasing a sense of obligation among states to adhere to rules and agreements. Second, institutions help reduce transaction costs. Specifically, international regimes establish rules and principles of legitimacy so interactions among states that violate these principles will be costly. In this aspect, institutions do not only create an increased sense of obligation but also provide for specific retaliation to prevent attempted cheating or possible free riding encouraged by multilateral norms. Third, institutions help provide information in order to reduce uncertainty about others' intentions, preferences, and their willingness to implement commitments.

In short, the significance of international regimes on state behaviour in the neo-liberal view lies primarily in their regulative effects, the monitoring and enforcement of states' compliance with agreements, norms and rules. The issue of whether institutions have any impact on the process in which states come to accept norms is not important to neo-liberals. This is because they assume that when states negotiate to create institutions, they have already agreed upon particular norms and rules governing their behaviour. What is more important in

\footnotetext{
${ }^{43}$ Arthur A. Stein, "Coordination and Collaboration: Regimes in an Anarchic World," International Organization 36, no. 2 (1982): 314. See also Duncan Snidal, "Coordination versus Prisoners' Dilemma: Implications for International Cooperation and Regimes," The American Political Science Review 79, no. 4 (1985): 923-42; Lisa L. Martin, "Interests, Power, and Multilateralism," International Organization 46, no. 4 (1992): 765-92.

${ }^{44}$ Robert O. Keohane, After Hegemony: Cooperation and Discord in the World Political Economy (Princeton, N.J.: Princeton University Press, 1984), chapter 6.
} 
this view is whether states would comply with such norms and rules and how effective institutions are in making them conform.

In contrast, the issue of how and why a state comes to adopt and internalize international norms is the core question in constructivist studies of institutional institutions. Constructivists believe that institutions have significant impacts on states with regard to norm-taking. The following sections will provide more insights into the constructivist perspective on institutional effects and normtaking as a key behavioural change on the part of states resulting from endogenous interactions in institutional environments.

\section{Constructivism}

According to Jeffrey Checkel, constructivism with its strong roots in sociology provides an alternative to the rationalist approach to the study of international politics. ${ }^{45}$ The constructivist approach emphasizes the social aspect of the environment in which states act. It argues that their identities and interests are generated by and changed as a result of such social interactions. In other words, actors do not exist independently from their social environment. Constructivism therefore contrasts sharply with realism in three ways. First, it sees states as social actors in the sense that their identities and interests are endogenous, rather than exogenous, to interactions. ${ }^{46}$ Second, states and structures are mutually constructed. Constructivists place considerable emphasis on the constitutive aspect of interactions that contributes to the (re)shaping of state identities and interests. Third, while neo-realists assume state interests and

\footnotetext{
${ }^{45}$ Jeffrey T. Checkel, "The Constructivist Turn in International Relations," World Politics 50, no. 2 (1998): 14. For an updated introduction on constructivism, see also Emanuel Adler, "Constructivism and International Relations," in Handbook of International Relations, eds. Walter Carlsnaes, Thomas Risse and Beth A. Simmons (London: SAGE, 2002); Ian Hurd, "Constructivism," in Handbook of International Relations, eds. Christian Reus-smit and Duncan Snidal (Oxford University Press, 2008), 298-316.

${ }^{46}$ Scott Burchill et al., Theories of International Relations (Basingstoke, Hampshire [U.K.]; New York Palgrave Macmillan, 2008), 223.
} 
behaviour flow from the distribution of power, constructivists treat identity as an independent variable in studying the formation of interests. As Alexander Wendt argues, interests are a function of state identities. ${ }^{47}$

Institutions are central to the constructivist view of international relations. ${ }^{48}$ Over the past two decades, constructivists have gone beyond asserting institutions "matter" in world politics, to show how powerful they are in influencing state action. As Thomas Risse has observed, constructivist institutionalism “adopts a 'thick' understanding of international institutions as social structures deeply embedding actors such as states." 49 In this view, institutions not only constrain and regulate actors' behaviour and strategies, but also constitute these actors in the sense that they define their identities and interests. At the core of the constructivist approach is the study of the possibility of state socialization - a process where actors come to adopt and internalize norms embedded in institutions.

\section{Institutions and state socialization}

Here there are two distinct approaches which we can call socialization by or in international institutions. ${ }^{50}$ In the former approach - the "socialization by" strand - international institutions are treated as potential purposive actors with independent effects on states. Among the earliest work is Martha Finnemore's argument that international institutions are instrumental in teaching states new norms or values, with a view to changing states' perceptions of and defining or

\footnotetext{
${ }^{47}$ Alexander Wendt, Social Theory of International Politics (Cambridge: Cambridge University Press, 2012), 233.

${ }^{48}$ Acharya, "Asian Regional Institutions and the Possibilities for Socializing the Behaviour of States."

${ }^{49}$ Risse, 605.

${ }^{50}$ See Jeffrey T. Checkel, "International Institutions and Socialization in Europe: Introduction and Framework," International Organization 59, no. 4 (2005): 801-26.
} 
redefining their interests. ${ }^{51}$ In National Interests in International Society, Finnemore explores the role of the United Nations Educational, Scientific and Cultural Organization (UNESCO), the International Committee of the Red Cross and the World Bank in teaching states new international norms. Here I call this socialization process vertical socialization since the relationship between the institutions and states resembles the relationship between teachers and students. In such a relationship, Finnemore argues, institutions have both generative and constitutive aspects, disseminating new norms and constituting new interests and values for actors. ${ }^{52}$

In contrast, the "socialization in" approach developed by Alastair Iain Johnston treats institutions as social environments. Through interactions and specifically through three socialization micro-processes, actors come to change their behaviour to become more cooperative, a shift manifested in norm-taking. According to Johnston these three distinctive processes - mimicking, social influence and persuasion - can lead to shifts in actors' preferences and behaviour, in what I call horizontal socialization. Having pointed out that socialization is a neglected source of cooperation in international relations, Johnston's goal is to find a new way of explaining cooperation by studying how state agents are socialized to accept new norms as a result of participation in international institutions and their effects, in turn, on the formation of state foreign policy.

Horizontal socialization is different from vertical socialization in several important ways. First, actors in institutional environments - or the units of analysis - are state agents, including diplomats, decision makers, analysts, or policy specialists, rather than states. Second, rather than potential purposive actors, international institutions are treated as social environments in which actors

\footnotetext{
${ }^{51}$ Martha Finmmore, National Interests in International Society (Ithaca, N.Y.: Cornell University Press, 1996).

${ }^{52}$ Ibid., 5-6.
} 
interact among themselves and with their environment. Institutions are believed to be conducive to socialization micro-processes through which individuals and small groups accept norms embedded in institutions they belong to. It is these socialized agents who will then have influence on the decision making process of the state they represent, contributing to shaping or redefining their state interests and behaviour in a more cooperative manner. Third, identifying socialization mechanisms that lead to change in actors' behaviour and potentially their preferences is another feature distinguishing horizontal from vertical socialization. As Johnston noticed, the diffusion of norms in the vertical socialization model seems "virtually automatic, even, and predictable," thus leaving various processes unexplained. ${ }^{53}$ These processes are significant because it is through them that actors "understand, process, and act upon the lessons that are 'taught' by international institutions." ${ }^{54}$ In other words, it is through these processes that one can observe the effects of the logic of arguing and of appropriateness that actors follow toward accepting norms.

Johnston seeks to fill this gap by identifying three separate socialization mechanisms that lead actors to adopt particular norms. This is significant because as Martin and Simmons point out, structuring the debate around the question of whether institutions matter was a response to the realist agenda. As a result, little attention has been paid to studying the mechanisms through which institutional effects were expected to work. ${ }^{55}$ In this sense, Johnston's socialization theory has a role to play in developing research along this path.

As noted, Johnston specifies three socialization micro-processes that he suggests lead to an actor's pro-norm behaviour. The first is mimicking - the act of copying behaviour of others in a group. Copying the behaviour of others happens

\footnotetext{
53 Johnston, “Treating International Institutions as Social Environment," 492.

${ }^{54}$ Ibid.

55 Lisa L. Martin and Beth A. Simmons, "Theories and Empirical Studies of International Institutions," International Organization 52, no. 4 (1998): 742-43.
} 
when newcomers try to adapt to the uncertain environment. In international institutions, mimicking often involves the actor's borrowing of working procedures and routines, language or talking about the issues that are central to the institutions. $^{56}$

A second mechanism is social influence - a socialization process that elicits an actor's pro-group behaviour through the distribution of a group's social rewards (i.e. status, recognition) and punishments (i.e. criticism, shaming). ${ }^{57}$ The outcome of successful social influence is an actor's conformity with the position advocated by the group, particularly with what most members in the group do or what they believe should be done. For those actors who care about their image and status, social influence can affect their behaviour in important ways: supporting the group's position would help them achieve social objectives such as improving their image, status and credibility or avoid a loss of status, shaming or humiliation. Conformity with a group's position as a result of social influence is therefore described as public conformity without private acceptance: "I believe the answer is X, but others said Y, and I don't want to rock the boat, so I'll say Y."58

The third mechanism is persuasion. This micro-process "involves changing minds, opinions, and attitudes about causality and affect (identity) in the absence of overtly material or mental coercion." $" 59$ The outcome of successful persuasion is the creation of common knowledge or a homogenization of interests. In institutional environments, persuasion involves an actor's assessment of the persuasiveness of arguments for particular norms, values or attitudes conveyed by the group. Through such assessment process, actors become convinced that such norms, values or attitudes are correct and appropriate. Persuasion therefore differs

\footnotetext{
${ }^{56}$ Johnston, Social States, Chapter 2.

${ }^{57}$ Johnston, "Treating International Institutions as Social Environments, "499-506.

${ }^{58}$ Quoted in Johnston, "Treating International Institutions as Social Environments," 499.

${ }^{59}$ Ibid., 496.
} 
from social influence in that it entails public conformity with private acceptance: "I thought the answer is X, but everybody else said Y, so it really must be Y."60

In short, socialization in its truest sense is an actor's internalization of new norms through persuasion. This micro-process arguably leads to not only the most durable and self-reinforcing pro-norm behaviour, but also change in an actor's preferences. In contrast, mimicking is the process with fewest social effects on an actor and social influence is an indirect one.

\section{Socialization theory and the Asia-Pacific region}

Recently, socialization - as a concept, a process or theory - has received greater attention from scholars studying international relations in Asia-Pacific. As a concept or process, socialization has widely been used by constructivists for the study of regionalism in Southeast Asia. ${ }^{61}$ For instance, Amitav Acharya in his book Constructing a Security Community in Southeast Asia argues that through socialization norms exert both regulative and constitutive effects on state behaviour toward shared principles and practice of peaceful conduct, thus contributing to the development of a sense of community. ${ }^{62}$ Socialization in this sense serves as a mediated process against which norms regulate and shape state behaviour.

The prevalence of institutions with design features arguably conducive to socialization and the presence of a number of states considered as targets for socialization means that Asia offers real potential for testing socialization theory. There have been a number of attempts to explore the power of socialization in

\footnotetext{
${ }^{60}$ Quoted in Johnston, "Treating International Institutions as Social Environments," 499.

${ }^{61}$ Amitav Acharya, "Theoretical Perspectives on International Relations in Asia," in International Relations of Asia, eds. David Shambaugh and Michael Yahuda (Lanham, Md.: Rowman \& Littlefield Publishers, 2008), 69.

${ }^{62}$ Amitav Acharya, Constructing a Security Community in Southeast Asia: ASEAN and the Problem of Regional Order (London: Routledge, 2009), 26-27.
} 
making shifts in foreign policy behaviour by states after joining regional institutions. For example, Acharya examines the role of Asian regional institutions in socializing Vietnam, China and India. ${ }^{63} \mathrm{He}$ argues that the key change after Vietnam joined ASEAN was its acceptance and internalization of the nonintervention norm. In the case of China, the key change was its adoption of a multilateral approach to conflict management. And for India, the key change as a result of socialization was the shift from economic nationalism and protection to trade liberalization.

Another scholar, Tan See Seng, examines the role of peer pressure in the ASEAN framework in making reluctant member(s) change their attitude toward supporting particular positions or norms of the organization. ${ }^{64}$ Having pointed out political suasion is the key modality through which ASEAN members develop a shared perspective, given that ASEAN-decision making has been consensusbased, Tan tests the effects of persuasion in three case-studies, namely Indonesia and the formation of ASEAN, the establishment of the ASEAN Charter, and the constructive engagement of Myanmar. Regarding the establishment of the human rights body as provided in the ASEAN Charter, for example, Tan argues that persuasion rather than force-based coercion led to the endorsement of the initiative by more reluctant ASEAN members, including Vietnam, Laos, and Myanmar. Evidence of persuasion was also found in two other instances, giving more support for the plausibility of socialization as an explanation for the cooperative behaviour of ASEAN members on the basis of the logic of appropriateness.

Meanwhile, Mathew Davies - in an effort to challenge the dominance of constructivism in regional studies, particularly the role of norms in shaping state

\footnotetext{
${ }^{63}$ Acharya, "Asian Regional Institutions and the Possibilities for Socializing the Behaviour of States."

${ }^{64}$ Tan, "Herding Cats: The Role of Persuasion in Political Change and Continuity in the Association of Southeast Asian Nations (ASEAN)."
} 
behaviour - argues that ASEAN's engagement with human rights norms, implicitly including the creation of a human rights body, has been strategically driven rather than morally driven. ${ }^{65}$ In Davies' view, constructivists have overstated the power of norms in shaping state behaviour: the weakness of constructivism, he argues, is evidenced by its failure to explain why ASEAN did not comply with the norms that it had promoted. Davies argues ASEAN has used human rights norms as a tool for political ends; that is, to increase its legitimacy in the eyes of external and internal actors. This leads him to conclude that a rational choice framework rather than constructivism can provide a more persuasive explanation of ASEAN's pro-human rights behaviour.

While Tan and Davies do not engage in a direct debate, their different perspectives on the same issue, namely ASEAN's engagement with human rights norms, reflect the rationalist-constructivist divide relating to the logic of action of norm-taking. According to Thomas Risse, socialization is the main process through which constructivist institutionalism interprets the logic of appropriateness to provide an account of how international norms acquire their "taken for grantedness." ${ }^{, 66}$ Put differently, through socialization actors will come to endorse particular norms, believing in their rightness and correctness and voluntarily abiding by those norms. In contrast, the logic of consequences emphasizes the instrumentality of actors in taking norms: actors try to realize their preferences through strategic behaviour and taking norms is to maximize or to optimize their interests and preferences.

In fact, constructivists do recognize the role of material and rational factors in explaining cooperation. But their emphasis on the importance of ideational and social elements in studying a particular phenomenon aims to provide an

\footnotetext{
${ }^{65}$ Mathew Davies, "ASEAN and Human Rights Norms: Constructivism, Rational Choice, and the Action-Identity Gap," International Relations of the Asia-Pacific 13, no. 2 (2013): 207-31.

${ }^{66}$ Risse, "Constructivism and International Institutions: Toward Conversation across Paradigms," 606.
} 
alternative account. As Tan observes, there is increasing agreement among scholars that appropriateness and consequentiality are not necessarily incompatible. $^{67}$ If so, conducting investigations about socialization, which emphasises norm-taking driven by the logic of appropriateness, is also a test to see if the other logic of action - the logic of consequences - plays any role. This study of Vietnam's participation in international institutions seeks to explore precisely this question.

${ }^{67}$ Tan, 239. See also, James Fearon and Alexander Wendt, "Rationalism v. Constructivism: A Skeptical View," in Handbook of International Relations, eds. Walter Carlsnaes, Thomas Risse and Beth A. Simmons (London: SAGE, 2002), 52-72; Michael Zurn and Jeffrey T. Checkel, "Getting Socialized to Build Bridge: Constructivism and Rationalism, Europe and the NationState," International Organization 59, no. 4 (2005):1045-79; Ian Hurd, "Constructivism," in Oxford Handbook of International Relations, eds. Christian Reus-Smit and Duncan Snidal (USA: Oxford University Press, 2010), 298-316. 


\section{CHAPTER III}

\section{INSTITUTIONAL DESIGN AND SOCIALIZATION}

This chapter provides an analysis of the institutional features of ASEAN, the ARF and the UNSC to measure the extent to which they are conducive to socialization. As Johnston suggests, persuasion is more likely to happen and it will be easier for a novice to be persuaded if the social environment has the following characteristics: (i) a small membership; (ii) the institutional franchise recognizes the special authoritativeness of a couple of actors; (iii) when decision rules are based on consensus; (iv) when mandate is deliberation; and (v) when the

autonomy of agents is high. ${ }^{68}$ But how are these institutional features conducive to persuasion? Johnston clarifies three routes through which an actor is persuaded and explains why these institutional features help facilitate each one.

First, the possibility that an actor changes his/her attitude depends on his/her relationship with the persuader, because the persuadee tends to assess new information based on the source of that information. If information comes from in-groups or those the actor likes, that information is more convincing than if it comes from out-groups or those he/she dislikes. Thus, it is more likely that the actor would change his/her mind, opinions and attitudes if information comes from those that he/she likes or shares traits with. Therefore, Johnston suggests that in an environment with a small membership, in-group identity effects on the persuasiveness of the counter-attitudinal messages are strongest. ${ }^{69}$ In addition, if the institution recognizes the special authoritativeness of a couple of actors that means for a novice their information will be more reliable than from other sources. $^{70}$

\footnotetext{
${ }^{68}$ Johnston, "Treating International Institutions as Social Environments," 509-10.

${ }^{69}$ Ibid., 509.

${ }^{70}$ Ibid.
} 
Second, an actor is more likely to be convinced of the information if he/she engages in a high intensity process of cognition in which he/she has to carefully consider the possible implications for his/her interests if holding their initial attitude. In an institution with decision-making rules based on consensus, cognition effects will arguably be strongest because consensus requires deliberation, thus requiring the actor to actively assess the message or counterattitudinal information and carefully consider the implications of holding the initial attitude for his/her interests. It is through this active assessment process that the probability of attitudinal change on the part of the actor increases.

Third, the possibility that an actor changes his/her attitude depends on his/her own characteristics, including the cognitive-processing capability, the strength of existing attitude, or the degree of independence in relation to his/her principal. If the mandate of the institution is deliberative, it not only requires active complex cognition on the part of the actor but also helps increase his/her autonomy in relation to the principal. This is because "deliberation" as mandate means there would be no obvious distribution of benefits at stake, so an actor may not have to report to or to receive instructions from his/her principal. In other words, an actor will be given some degree of free choice in decision making. As a result, the possibility of actor's attitudinal change is higher.

In contrast, environments conducive to social influence have the following features: (i) large membership; (ii) the franchise is equally allocated; (iii) decision rules are majoritarian or reasons for supporting or opposing consensus are on record; (iv) the mandate is negotiation; and (v) the autonomy of agents is low. Since social influence leads to an actor's conformity with the group's position through the distribution of social rewards or punishments, these institutional features arguably make the effects of such rewards and punishments stronger on the actor. For an actor who cares about his/her status and image, the role of an institutional structure in facilitating his/her cooperation is through the provision of 
information about the degree to which he/she is behaving in ways consistent with the group's prior shared understanding of what constitutes an appropriate behaviour. For instance, if there is a wide distance between an actor's behaviour and that shared understanding of good behaviour, then the larger the number of observers of the actor's behaviour, the more powerful the shaming effect will be. ${ }^{71}$ In other words, a large membership will help generate greater pressure on the actor, compelling him/her to act in a more consistent manner with the shared standard of behaviour. Conversely, if an actor is trying to maximize his/her status through supporting particular positions of the group, the presence of a large number of members will help increase the level of praise and recognition as social rewards for conformity.

The institution's monitoring effects are also furthered if decision rules are majoritarian because the actor's behaviour is on record and consistency effects may be stronger. ${ }^{72}$ Other institutional features, including equal allocation of authoritativeness, negotiation as mandate and low agent autonomy arguably help reduce the effects of persuasion. Without a small number of highly authoritative actors, there would be no persuasive sources of new information; negotiations over the distribution of benefits would make it more difficult for the actor to be persuaded; and low autonomy would not give him/her much freedom to make decisions on his/her own.

Against the above criteria, the following section will examine the institutional features of ASEAN, the ARF and the UNSC as the three selected institutions and the individual features of Vietnamese representatives as targets of socialization. A closer look at the institutional features of these three institutions reveals that they are all more conducive to persuasion than social influence.

\footnotetext{
${ }^{71}$ Ibid., 502.

72 Ibid., 510.
} 


\section{The Association of Southeast Asian Nations}

As a social environment, ASEAN meets more criteria to be conducive to persuasion than social influence. First, the organization has a small membership. Formed in 1967 with five founding members, Indonesia, Malaysia, the Philippines, Singapore and Thailand, it expanded with the accession of Brunei in 1984 and then a group of four states in the second half of the 1990s: Vietnam, Laos, Myanmar and Cambodia. The inclusion of ten Southeast Asian countries under the roof of ASEAN was once considered one of the great achievements of the organization. Second, ASEAN's mandate has been deliberative. Since its inception, ASEAN deliberations have primarily taken the form of consultations and dialogues among members on intra-regional problems and concerns with the annual ASEAN Ministerial Meeting as the most important and regular interaction. ${ }^{73}$ Third, ASEAN's decision-making process has long been based on consensus. Though consultations and consensus in the ASEAN context always go hand in hand, there are some important points regarding consensus as a decisionmaking rule as opposed to consultations which are covered here by mandate: (i) ASEAN has long avoided majority voting and prefers consensus as its decisionmaking rule, given its concern that the former can lead to the imposition of views by the majority on the minority; (ii) decisions made on the basis of consensus must be acceptable to all. Consultations play the key role in ensuring that the views of every member will be taken into consideration and reflected in the final decisions. As such, consultations help facilitate the process toward achieving consensus; (iii) consensus is different from unanimity. In the ASEAN context decisions made by consensus do not always mean every member feels comfortable or satisfied with them. Rather, as long as their basic interests are not disregarded they can go along with the decision. ${ }^{74}$

\footnotetext{
${ }^{73}$ Khong and Nesadurai, "Hanging Together, Institutional Design, and Cooperation in Southeast Asia: AFTA and the ARF," 41.

${ }^{74}$ Acharya, Constructing a Security Community in Southeast Asia, 82-85.
} 
ASEAN's mandate and decision-making rules largely remain intact although its institutional scope has expanded since the end of the Cold War. The ASEAN Charter adopted in 2007 reaffirms that "decision-making in ASEAN shall be based on consultation and consensus." "75 And with the adoption of the ASEAN Charter, further steps in the institutionalization of regular consultations and meetings have been taken at various levels. ${ }^{76}$ Regular consultations are not limited to the ASEAN Ministerial Meeting. As the supreme policy-making organ of ASEAN, the ASEAN Summit now convenes twice a year and its mandate is to “deliberate, provide policy guidance and take decisions on key issues pertaining to the realization of the objectives of ASEAN, important matters of interest to member states and all issues referred to it by the ASEAN Coordinating Council, the ASEAN Community Council and ASEAN Sectorial Ministerial Bodies."77 Interactions among state members became more intensified when the scope of cooperation was expanded and regular consultations taken at different levels.

It was obvious that enlargement in the 1990s to include new members with differences in political systems and level of economic development presented ASEAN with the task of socializing these new members into its organizational methods and procedures, among others. ${ }^{78}$ For instance, Amitav Acharya wondered if the new members could be socialized into the ASEAN Way. ${ }^{79}$

The "ASEAN Way" has widely been understood as the core feature of ASEAN design that comprises principles regulating the relationship among state members and determining the working style and decision-making rules of the

\footnotetext{
75 “The ASEAN Charter," ASEAN, November 20, 2007, http://www.asean.org/archive/publications/ASEAN-Charter.pdf.

${ }^{76}$ Ibid., Chapter IV.

${ }^{77}$ Ibid., Article 7 (2.b).

78 Michael Wesley, "Membership Expansion and Change," in The Regional Organizations of the Asia Pacific: Exploring Institutional Change, ed. Michael Wesley (Houndmills, Basingstoke, Hampshire; New York: Palgrave Macmillan, 2003), 112-14.

${ }^{79}$ Acharya, Constructing a Security Community in Southeast Asia, 87.
} 
organization. ${ }^{80}$ Core principles that govern behaviour among member states include respect for the independence, sovereignty and equality, territorial integrity, national identity, non-interference in the internal affairs of another state, non-use of force and pacific settlement of disputes. These principles have been incorporated in various ASEAN documents such as the Treaty of Amity and Cooperation in Southeast Asia adopted in 1976 and most recently in the ASEAN Charter. ASEAN members have long upheld these principles because they ensure the independence of all in deciding their domestic policies. ${ }^{81}$ This reflects their preference for consolidation of state sovereignty even when cooperation is expanded to cover new issues. Meanwhile, ASEAN's working style stresses the importance of informality, flexibility, consensus-building and non-confrontational bargaining styles as the mode of the organization's operation. ${ }^{82}$ With regard to consensus-building, Acharya points out two important aspects of the process: the non-hostile setting of consultation, and a commitment to find a way of moving forward that enjoyed broad support by taking into account the interests of all members. ${ }^{83}$

For Vietnam, these "ASEAN Way" principles have been of vital importance given its preference for protecting sovereignty in the new context of the post-Cold War era. ASEAN's working style was also of importance because Vietnam was a genuine novice in latter half of the 1990s and early 2000s. The social environment in ASEAN during this period facilitated the accommodation of Vietnam as well as other new members into a new environment in which:

\footnotetext{
${ }^{80}$ Acharya, "Ideas, Identity, and Institution-Building: From the 'ASEAN Way' to the 'Asia Pacific Way?" 328-33; For a comprehensive review of the emergence and nature of the "ASEAN Way" see Severino, Southeast Asia in search of an ASEAN Community, 1-40; Acharya, Constructing a Security Community in Southeast Asia, 54-98.

${ }^{81}$ Khong and Nesadurai, 42.

${ }^{82}$ Ibid.

${ }^{83}$ Acharya, "Ideas, Identity, and Institution-Building: From the 'ASEAN Way' to the 'Asia Pacific Way?" 330-31.
} 
- Actors' independence is respected.

- Regular consultations created opportunities for greater and active participation of new members;

- Voices of new members were to be heard and encouraged;

- Preferences, concerns and differences to be raised, taken into account and settled through discussions;

- Old members refrained from imposing their own norms and values;

- Arguments and dissemination of new information were presented in nonthreatening way; and

- Cooperation moved at a pace comfortable to its slowest members.

For the first generation of Vietnamese officials involved in ASEAN activities, this environment helped them gain a better understanding of those they were communicating with; familiarized them with new working styles at a multilateral institution; explored new areas of cooperation in which they had to think about the implications for national interests such as economic cooperation in the framework of ASEAN Free Trade Area (AFTA); and meant they learned how to cooperate with other members to deal with problems that the institution was faced with as a whole, such as addressing the 1997-98 economic crisis. ${ }^{84}$ Therefore, the noviceness of the Vietnamese participants in those early years in ASEAN can be characterized in part by a lack of capacity and efforts to address this, ranging from improving English skills for officials, getting used to working procedures, to practising hosting a number of meetings. ${ }^{85}$

However, this first generation of Vietnamese officials in ASEAN did not enjoy much autonomy. The most important reason was the centralization of Vietnamese foreign policy-making whereby decisions were always made at the highest level of the Party and State. ${ }^{86}$ The decision to join ASEAN is one example: it was made by senior figures in the CPV's Politburo. This system does

${ }^{84}$ MOFA ASEAN Department Research Project "On Review of Vietnam's Participation in ASEAN in the first Five Years: Achievements, Challenges and Prospects," (2001), 106-13.

${ }^{85}$ For example, Vietnam held the first ASEAN Chairmanship in 1998, three years after its accession to ASEAN.

${ }^{86}$ See Zachary Abuza, "Institutions and Actions in Vietnamese Foreign Policymaking: A Research Note," Contemporary Southeast Asia 19, no 3 (1997): 309-33. 
not allow officials to enjoy much freedom. Within MOFA officials were routinely required to report to their principals on developments relating to issues and areas that they were in charge of. In short, Vietnam's participation in ASEAN in the early years was of an exploratory and learning nature, where officials reported to their principals on every aspect of cooperation and at the same time had to wait for instructions on how to participate. As a result, state agents had limited independence in deciding any matters on their own. Officials' limited knowledge and skills, especially English fluency, also inhibited their effective participation in ASEAN activities. In addition to this, Vietnam was unable to participate in all ASEAN meetings due to a lack of human and financial resources. ${ }^{87}$ Interactions in the 1990s were therefore of a very low quality.

Vietnam has become less of a novice as time has gone by. As a result, the social environment in ASEAN has also become less conducive to socialization. For a member like Vietnam, the introduction in the late 1990s of new norm of "flexible engagement" posed a direct challenge to the non-interference norm that Vietnam had long upheld. Former Thai Foreign Minister Surin Pitsuwan proposed this idea with a view to making ASEAN more effective by allowing its members to comment on each other's policies, especially when dealing with domestic issues with regional implications. However, new ASEAN members strongly opposed the initiative and "flexible engagement" was finally replaced with "enhanced interaction" - a milder term that affirms the non-intervention principle and assures the freedom of ASEAN members in engaging with one another. ${ }^{88}$ Entering the first decade of the $21^{\text {st }}$ century, ASEAN was determined to work toward a more rules-based group with the goal of building an ASEAN

\footnotetext{
87 MOFA ASEAN Department Research Project, "On Review of Vietnam's Participation in ASEAN in the first Five Years: Achievements, Challenges and Prospects," 109.

${ }^{88}$ For more details, see Acharya, Constructing a Security Community in Southeast Asia, 176-78; Jurgen Haacke, "The Concept of Flexible Engagement and the Practice of Enhanced Interaction: Intramural challenges to 'ASEAN Way'," The Pacific Review 12, no. 4 (1999): 581-611.
} 
Community. This put newcomers in a more difficult situation of how to reconcile their national interests with that of the Association.

Since ASEAN cooperation has been expanded to include a wider range of cooperation schemes and plan of actions, interactions within the ASEAN framework and coordination at the domestic level have increased as well. This has had two significant effects for Vietnam. First, officials participating in ASEAN affairs are now more diverse, including representatives from the MOFA, the National Assembly, the Ministry of Trade and Industry, the Ministry of National Defence and other governmental branches. Second, the country's participation in ASEAN over the past two decades has also brought a younger generation of officials into institutional deliberations. At MOFA, this group of younger officials, together with those who have gained experience since the early years in ASEAN now constitutes the core group in charting out the country's orientation toward participation in ASEAN, making and implementing concrete proposals on a wide range of cooperative schemes. ${ }^{89}$ It was acknowledged in the ten year review of participation in ASEAN in 2005 that the expertise, working experience in multilateral settings and especially English fluency of Vietnamese officials had improved enormously. ${ }^{90}$ The maturity of Vietnamese officials can best be seen in the drafting process of the ASEAN Charter in 2007. During this process, former ASEAN Secretary-General Ong Keng Yong was impressed by the prominence and confidence of Task Force members from Cambodia, Laos, Myanmar and Vietnam. In his view, ASEAN had become a group of equals, at least in terms of negotiating skills. ${ }^{91}$

\footnotetext{
${ }^{89}$ This is most visible in 2010 when Vietnam held the ASEAN Chair.

${ }^{90}$ MOFA ASEAN Department Report “On Vietnam's Ten Year Participation in ASEAN,” (2005), 11.

${ }^{91}$ Ong Keng Yong, "At Close Quarters with the Drafting of the ASEAN Charter," in The Making of the ASEAN Charter, eds. Tommy Koh, Rosario G. Manalo and Walter Woon (Singapore; Hackensack, NJ: World Scientific Pub. Co., 2009), 113.
} 
The expansion of technocrats and experts groups has been a result of Vietnam's increased participation in institutional life over the past two decades. In addition, a process of gradual decentralization of the foreign policy making process has meant MOFA now plays a dominant role. Vietnamese officials involved in ASEAN activities now can enjoy more latitude; and can be more confident and pro-active than those who worked in the latter half of the 1990s.

\section{The ASEAN Regional Forum}

The ARF is the most important multilateral security forum in the AsiaPacific. It was formed in 1994 with eighteen members, including six ASEAN states, their dialogue partners and China, Vietnam, Laos, and Papua New Guinea. ${ }^{92}$ More members joined as the institution evolved, bringing the total current membership to twenty seven. ${ }^{93}$ The ARF's membership is therefore not only larger, but also more diverse than that of ASEAN. However, in relation to socialization theory, except for its large membership, the ARF like ASEAN, also shares institutional properties that are arguably conducive to persuasion. The Forum's franchise recognizes the leadership of ASEAN. That means ASEAN is at the core of the ARF's operation. The ARF's annual foreign ministers meeting is held after the ASEAN Ministerial Meeting, with an ASEAN member as host country in the chair. The ARF's mandate is deliberative and its decision-making rule is also consensus-based. In Social States Johnston identifies the ARF as a key example of where persuasion occurs, leading to China's adoption of the cooperative security norm. ${ }^{94}$

\footnotetext{
92 "About the ASEAN Regional Forum," ASEAN Regional Forum, accessed October 10, 2010, http://www.aseanregionalforum.org.

${ }^{93}$ Ten ASEAN members, the United States, Japan, China, Canada, the EuropeanUnion, Republic of Korea, Australia, New Zealand, Russia, Papua New Guinea, India, Mongolia, Democratic People's Republic of Korea, Pakistan, Timor-Leste, Bangladesh and SriLanka.

${ }^{94}$ Johnston, Social States, chapter 4.
} 
However, in order to have a better understanding of the ARF as a social environment, its institutional features need clarification. One key feature is ASEAN's leadership. Although some scholars criticize and downplay the organization's role, ${ }^{95}$ for Vietnam as a potential target of socialization, ASEAN is a critical reference group. In the early years of participation in the ARF when Vietnam sat for the first time alongside former enemies, it was ASEAN that Vietnam looked toward as the main reference group, together with China, when assessing new information.

A second feature is the ARF's mandate. The 1995 Concept Paper set out a three-stage process for ARF development: Stage I focuses on confidence-building among participants through measures aiming at increasing transparency such as dialogue on security perceptions, the voluntary publication of Defence White Papers and exchanges between and among defence and military circles; Stage II focuses on the development of Preventive Diplomacy through, for example, exploring and devising ways and means to prevent conflict; and Stage III is for the development of conflict-resolution mechanisms. ${ }^{96}$ Since the ARF's participants are diverse, the goal of setting a three-stage development is for the ARF to proceed at a comfortable pace to all. In particular, the focus on confidencebuilding measures (CBMs) in the first stage was designed to help reduce lingering mistrust among some participants. ${ }^{97}$ CBMs are critical for socializing a novice like Vietnam, whose dichotomy of friends or foes still dominated in the years after the Cold War, thus mistrust and suspicion were inevitably unavoidable.

A third feature is the ARF's decision-making rules and working methods. The Concept Paper provides: "Decisions should be made by consensus after

\footnotetext{
${ }^{95}$ Rizal Sukma, "The Accidental Driver: ASEAN in the ASEAN Regional Forum," in Cooperative Security in the Asia-Pacific: The ASEAN Regional Forum, eds. Jurgen Haacke and Noel M. Morada (London \& New York: Routledge: 2010), 114.

96 "The ASEAN Regional Forum: A Concept Paper," ASEAN Regional Forum, accessed August 13, 2013, http://aseanregionalforum.asean.org.

${ }^{97}$ Khong and Nesadurai, 63.
} 
careful and extensive consultations. No voting will take place."98 ${ }^{\text {These working }}$ procedures have long been upheld in inter-sessional group meetings (ISG) - the core ARF Track One activities - which discuss such issues as confidence building measures, peacekeeping; search and rescue, disaster relief, defence, counterterrorism; and non-traditional security issues. For Vietnam, consensus, careful and extensive consultations are of significance because embedded in these procedures is respect for its independence. In particular, the design of inter-sessional year meetings is to facilitate careful and extensive consultations among participants by giving them more time and freedom to consider the issues and positions taken by others so as to be well-prepared when entering discussions. If consensus cannot be reached in one meeting, deliberations will be continued in those that follow.

Taken together, the ARF's institutional features - moving at a comfortable pace to all, non-binding decisions, voluntary actors' responsibilities, consultations, respect for actor independence - are conducive to persuasion in the sense that they all give the potential targets of socialization a certain degree of free choice in assessing the message conveyed by persuaders. Since Vietnam was a genuine novice in the 1990s and its perception of security at that time was also undergoing a transformation, ${ }^{99}$ the $\mathrm{ARF}$ as a social environment would be most conducive to persuasion around that time, opening up the possibility for the adoption of new security concepts and norms by Vietnamese officials.

With almost two decades of involvement in this institution, Vietnam has become less of a novice. Indeed, the group of Vietnamese officials involved in the ARF has gradually grown in knowledge, expertise and working experience. They also enjoy greater latitude in relationship with their principals as a result of the decentralization of the country's foreign-policy making process. Because there is

\footnotetext{
98 "The ASEAN Regional Forum: A Concept Paper," ASEAN Regional Forum, accessed August 13, 2013, http://aseanregionalforum.asean.org.

${ }^{99}$ See Elliot, Changing Worlds, 63-64; 96-97.
} 
no separate department/unit at MOFA to take charge of ARF, the same people in the ASEAN Department are also responsible for ARF activities. Their tasks are to prepare for and participate in ARF SOMs, EEPs Meetings, and, most importantly, the ARF annual meetings with the presence of Foreign Ministers as the highest ranking officials. At the domestic level, they coordinate and facilitate the participation of officials from other ministries such as the Ministry of National Defence or Ministry of Public Security in ARF inter-sessional group meetings on specialized areas such as counter-terrorism and transnational crime. ${ }^{100}$

\section{The United Nations Security Council}

In contrast to ASEAN and the ARF, the United Nations Security Council (UNSC) is a highly institutionalized grouping. As such, it does not have the institutional design that Johnston expects to be associated with socialization. However, a closer look at specific institutional features suggests what is interesting about the UNSC is that it also holds some properties conducive to persuasion. First, it has a small membership, at least in comparison with that of other UN organs or the ARF. Second, by grouping its members into permanent members (P5) and elected non-permanent members (E10), the UNSC recognizes the special authoritativeness of the P5 by granting them the veto power and continuous membership. ${ }^{101}$ In other words, veto power and permanence give the P5 a privileged position in controlling this global institution, while non-permanent

\footnotetext{
${ }^{100}$ ASEAN 2010, http://asean2010.vn; As for track II activities, Vietnam is involved mainly in the Council for Security Cooperation in Asia-Pacific (CSCAP) activities, including CSCAP Study Group on Countering the Proliferation of Weapons of Mass Destruction (WMD) as co-chair with the US CSCAP; Export Controls Experts Group (XCXG) - a sub group of the Study Group on WMD; and Water Resources Security in Mainland Southeast Asia. Participants in CSCAP Study Group on Countering the Proliferation of Weapons of Mass Destruction are scholars from the Diplomatic Academy of Vietnam.

${ }^{101}$ See Sydney D. Bailey and Sam Daws, The Procedure of the UN Security Council (Oxford: Oxford University Press, 1998), 137-53.
} 
members are in a disadvantaged position given their lack of veto and two-year tenure. $^{102}$

The "authoritativeness" of the P5 refers to their privilege and "relational power" in relation to non-permanent members, rather than "a credible source of information" defined by Johnston that can influence the way a potential target of socialization (i.e. a non-permanent member like Vietnam) assesses the information from the persuader (one or more in the P5). However, in the case of Vietnam as one potential target of socialization, the presence of China and Russia in the P5 is important. These two powers have been Vietnam's traditional likeminded states. As a result, information from them must be more convincing and reliable than that from the remaining P5 members, namely the United States, the United Kingdom or France. In deliberations and discussions at the Council, it is these two powers that Vietnamese officials must look to first when formulating their position. As it was noted in the early part of this chapter, the presence of like-minded actors in an institution will make it more possible for a potential persuadee to change his/her attitude if information comes from these sources.

In addition to a small membership and the presence of China and Russia as Vietnam's like-minded states, the fact that the Council's working methods are based primarily on consultation and consensus are other institutional features that make the social environment in the UNSC more conducive to persuasion. As provided in the UN Charter, the Security Council is charged with the maintenance of international peace and security and has three primary functions: making recommendations to states as parties to a dispute; making recommendations to the General Assembly; and making mandatory (binding) decisions. ${ }^{103}$ For the first

\footnotetext{
${ }^{102}$ On the relationship between the P5 and the ten elected non-permanent members, see Kishore Mahbubani, "The Permanent and Elected Council Members," in The UN Security Council: From the Cold War to the 21st Century, ed. David M. Malone (Boulder, Colo.: Lynne Rienner, 2004), 253-80.

${ }^{103}$ Bailey and Daws, the Procedure of the UN Security Council, 18-20.
} 
two groups, the UNSC acts as an executive body, but for the third one, it sometimes acts like a legislature. ${ }^{104}$

Whether acting like an executive or legislature, consultation is the Council's key working method. As Bailey and Daws observed in 1998, much of the Council's work was carried out in the so-called "informal consultations," particularly informal consultations of the whole that the gradual formalization has given such informal meetings a de facto official status. ${ }^{105}$ These informal consultations are not only the private gatherings of all 15 Council members but also where bilateral and multilateral consultations between the President and individual members of the Council take place. ${ }^{106}$ Today, informal consultations are still the main format of meeting of the Council's members. ${ }^{107}$

In addition, in the $21^{\text {st }}$ Century the trend toward consensus in the Council's decision-making process has become salient. ${ }^{108}$ The democratization process in international relations in general and within the Council in particular has led to increased interactions among the Council's members and the result is that, as Kishore Mahbubani has observed, most Council decisions nowadays are made by consensus. ${ }^{109}$ Increased consensus is reflected in the adoption of resolutions by unanimity and of the use of President's statements. According to Hulton, though resolutions are still adopted by vote, nowadays almost all are adopted

\footnotetext{
${ }^{104}$ See Ian Johnstone, "The Security Council as Legislature," in The UN Security Council and the Politics of International Authority, eds. Bruce Cronin and Ian Hurd. (London; New York: Routledge, 2008), 80-104.

${ }^{105}$ Bailey and Daws, 60-66.

106 Ibid., 61.

107 The most recent revisions and updates on these informal meetings and other Council working methods were made in 2010. See "Note by the President of the Security Council," the United Nations Security Council, S/2010/507, July 26, 2010, http://www.securitycouncilreport.org/atf/cf/\%7B65BFCF9B-6D27-4E9C-8CD3CF6E4FF96FF9\%7D/Working\%20methods\%20S2010\%20507.pdf.

${ }^{108}$ See Susan C. Hulton, "Council Working Methods and Procedure," in The UN Security Council: From the Cold War to the 21st Century, ed. David M. Malone (Boulder, Colo.: Lynne Rienner, 2004), 237-51.

${ }^{109}$ Mahbubani, "The Permanent and Elected Council Members," 257.
} 
unanimously. ${ }^{110}$ The adoption of president's statements also requires consensus because they are adopted on behalf of the Council's members, thus every word "has been agreed in advance by all members of the Council." "111 In short, deliberations and consultations with a view to reaching a consensus among Council members are the key processes that happen before the Council can come to the final step of voting. From a socialization perspective, these processes therefore allow considerable space for persuasion and peer pressure to come in to influence an actor's attitude and preferences.

Vietnam's term as a non-permanent member of the Security Council in 2008-2009 was the first time it had served in this institution and was therefore a highly novel environment. Assuming the post presented a significant test for Vietnam's capability at global level. ${ }^{112}$ Indeed, the decision to bid for a Council's non-permanent membership dated back to 1997 and Vietnam had spent ten years preparing for its first term. ${ }^{113}$ The training of personnel was the most important task. Those chosen to work at the Council had to be sufficiently competent to work in such a demanding environment and have English fluency, among other criteria. In addition, the lack of familiarity with the Council's working procedures and of the issues debated required careful preparation prior to officially assuming

\footnotetext{
${ }^{110}$ Hulton, "Council Working Methods and Procedure," 237.

${ }^{111}$ Ibid., 238.

112 Due to the Cold War the relationship between Vietnam and the UN in 1977-1991 was minimal. Since 1991 Vietnam has gradually become more active, especially in such areas as peace and security, disarmament, socio-economic development, population and environment protection. Vietnam held and ran for important positions in several UN bodies such as Vice President of the UNGA in 1997, 2000 and 2003; member of ECOSOC (1997-2000); President of the 33rd General Assembly of Food and Agriculture Organization; member of Human Rights Committee (20012003); UN Executive Council for Development Program and Population (2000-2002); Governor Council of International Atomic Energy Agency (1991-1993, 1997-1999, 2003-2005); Managerial Council for World Postal Union (1999-2004); International Telecommunication Union (19941998, 1998-2002, 2002-2006), and UN Security Council as non-permanent member for the term 2008-2009. Most recently, Vietnam in 2013 was selected to be a member of the UN Human Rights Council. On security and disarmament, Vietnam actively participated in the negotiation and became a member of Chemical Weapon Convention (CWC) in 1998, signed the Comprehensive Nuclear-Test-Ban Treaty in 1996 and ratified this Treaty in 2006.

${ }^{113}$ MOFA Department of International Organizations Proposal "On the bid for a non-permanent membership at the UNSC," summited to MOFA leaders, dated 10 January, 1997.
} 
the post. For instance, a hotline was set up that allowed Vietnamese officials at the Mission in New York to directly report to and seek for instructions from the leadership at home. A list of approximately 60 issues, with Vietnam's position on each, was charted out for Vietnamese officials to act within these parameters. ${ }^{114}$ The size of Vietnam's delegation in New York is relatively small, comprising of about 27 people, mostly of a younger generation. However, not all are directly in charge of the Council's work. According to one official, only six or seven staff were directly involved in the Security Council's affairs. ${ }^{115}$

Given its huge workload and design to function continuously - requiring its members to convene at any time in response to emergency situations ${ }^{116}$ - the Security Council is one of the most intensive interactions in which Vietnamese officials as genuine novices found themselves. These situations included:

- Being repeatedly exposed to new issues, intensive exchanges and consultations, compelling them to assess new information and think harder about the implications of their future decisions for national interests.

- Being the targets of other members, particularly P5, seeking support for their positions since there are always circumstances that permanent members compete with each other for support from non-permanent members so as to adopt certain resolutions.

- Being in a highly cognitive process when receiving and assessing new information. It is in this situation that information from the sources of the "likes" or "dislikes" in P5 will no doubt exert influence on officials" decisions.

In short, ASEAN, the ARF and the UNSC meet many of the criteria required to be conducive to socialization, particularly persuasion, but none is an ideal environment for persuasion, especially when it comes to the issue of the

\footnotetext{
${ }^{114}$ MOFA Department of International Organizations Research Project "On Vietnam and the first non-permanent membership at the UNSC in 2008-2009: Experiences and Lessons" (2012).

${ }^{115}$ Interview by author with a Vietnamese official in Wellington, May 2013.

${ }^{116}$ Bailey and Daws, 4-5.
} 
level of agent autonomy. If the level of agent autonomy is confined to the relationship between agents and their principals, whereby agents are obligated to report to their principals, at least as an administrative requirement, Vietnamese officials do not enjoy much freedom, even after the country's foreign policymaking process was decentralized. However, there is another important aspect of agent autonomy that needs to be taken into account. The decentralization of foreign policy - making process in Vietnam proceeded in tandem with the emergence of different groups of experts (senior officials) who now play a crucial role in shaping the country's foreign policy as it further integrates into the region and the world. ${ }^{117}$ As a result, there is now a reversed trend in foreign policy making. It is no longer a top-down process as in the 1990s when instructions were given from the top leaders of the State and Party. Rather, it is now a two-way process with the bottom-up dimension playing a more important role.

Agent autonomy thus varies across the three selected institutions. In ASEAN, the first generation of officials - those who were genuine novices - did not enjoy much freedom during the 1990s due to their limited experience and working skills and most importantly because of the centralization of the foreign policy - making process. The current generation, however, enjoy more freedom, since decisionmaking process has been gradually decentralized and their knowledge and expertise have been enriched, allowing them to act more confidently and proactively. The situation in the ARF is the same since it involves the same Vietnamese officials. Meanwhile, Vietnamese officials in the highly novel environment of the UNSC did not seem to have much freedom, given the strict reporting and coordination mechanisms set up to scrutinize their operation. ${ }^{118}$ This

\footnotetext{
${ }^{117}$ In the CPV's Documents released every five years, MOFA has been involved in the drafting of the sections relating to foreign policy.

${ }^{118}$ A three-level decision making process - Ambassadors and Chief of Mission, the Foreign Minister and the Prime Minister, and the Politburo - was set up for Vietnamese officials to seek instructions and submit their monthly, six-monthly and annual reports on Vietnam's operation at the Council. MOFA Department of International Organizations Research Project "On Vietnam and
} 
situation thus appears similar to that of the 1990s when Vietnam prepared to join ASEAN. However, the setting up of these mechanisms was primarily technical, with a view to making the Mission's operation at the UNSC as effective as possible. When it came to the resolution of specific issues, no one could have a better understanding of the Council's work than those at the Mission. Therefore, Vietnamese officials in New York played a critical role in making policy recommendations on how Vietnam should address the Council's agenda items.

In the next three chapters we will explore in detail how these different institutional environments affected Vietnam's interests and behaviour in ASEAN, the ARF and the UNSC. To conclude here, however, the table below sets out the institutional features of ASEAN, the ARF and the UNSC and explains how they are conducive to persuasion.

\begin{tabular}{|c|c|c|c|}
\hline & ASEAN & ARF & UNSC \\
\hline Membership & $\begin{array}{l}\text { Small ( } 10 \\
\text { members })\end{array}$ & $\begin{array}{l}\text { Large ( } 27 \\
\text { members) }\end{array}$ & $\begin{array}{l}\text { Small (with } 15 \\
\text { members) }\end{array}$ \\
\hline Franchise & $\begin{array}{l}\text { Equal allocation of } \\
\text { authoritativeness }\end{array}$ & $\begin{array}{l}\text { Equal allocation of } \\
\text { authoritativeness }\end{array}$ & $\begin{array}{l}\text { Legitimately } \\
\text { unequal allocation } \\
\text { of } \\
\text { authoritativeness }\end{array}$ \\
\hline Mandate & Deliberative & Deliberative & $\begin{array}{l}\text { Deliberation and } \\
\text { Resolution }\end{array}$ \\
\hline $\begin{array}{l}\text { Decision making } \\
\text { rule }\end{array}$ & Consensus & Consensus & Majority voting \\
\hline Agent Autonomy & $\begin{array}{l}\text { Extremely low } \\
\text { during 1990s- } \\
\text { higher recently }\end{array}$ & $\begin{array}{l}\text { Extremely low } \\
\text { during 1990s- } \\
\text { higher recently }\end{array}$ & $\begin{array}{l}\text { Low in terms of } \\
\text { reporting } \\
\text { requirement, but } \\
\text { relatively high in } \\
\text { terms of making } \\
\text { policy } \\
\text { recommendations }\end{array}$ \\
\hline
\end{tabular}

the first non-permanent membership at the UNSC 2008-2009: Experiences and Lessons" (2012), p.75. 


\section{CHAPTER IV}

\section{ASEAN AND THE CREATION OF A HUMAN RIGHTS BODY}

This chapter examines if socialization worked to change Vietnam's position from opposing to supporting the creation of an ASEAN Human Rights Body (HRB). The drafting of the ASEAN Charter in 2007 revealed intense debates on whether a human rights body should be established at the regional level and if so what functions that body would have. The High Level Task Force (HLTF) in charge of drafting the Charter - which was composed of ten senior officials from ASEAN members - was split and their deliberations turned into a negotiation between two groups: participants from older ASEAN members who supported the initiative and those from newer members, namely Cambodia, Laos, Myanmar and Vietnam (CLMV) who were reluctant. However, the latter group finally agreed to the creation of the HRB. The decision to establish such an ASEAN-wide mechanism on human rights was significant: ASEAN members for the first time broke the taboo of discussing human rights issues intra-regionally, agreeing to take on regional responsibility in this sensitive area.

The chapter is in three parts. The first provides a brief introduction to ASEAN and the idea of the human rights body prior to the drafting process. Details of the negotiations on the HRB are provided in the second part to assess how the Vietnamese representative took part in the negotiations. The third section explores if persuasion and social influence can explain Vietnam's changed attitude from reluctance to endorsement of the creation of the ASEAN HRB.

By examining the social environment in which the Task Force negotiated, the characteristics of the Task Force members and their interactions throughout 
the negotiation process, the chapter argues that rather than being persuaded, it is clear that the Vietnamese representative did not trust the intentions of activist members. The immediate creation of the HRB proposed by the activists was seen as a radical move. Therefore, the Vietnamese participant sought ways to slow down the negotiations, preventing the immediate creation of the HRB.

Social influence provides a more plausible explanation for Vietnam's endorsement of the initiative. The decision was made primarily because of image concerns and "not rocking the boat." On the one hand, Vietnam did not want to be seen as blocking the process. On the other hand, attitudinal change on the part of other similarly-minded states, namely Laos, Myanmar and Cambodia, to become more supportive of the HRB led to change on the part of the Vietnamese. In other words, Vietnam would have found itself in a minority if it had not joined the majority to go along with the initiative.

\section{ASEAN and the idea of a Human Rights Body}

The Association of Southeast Asian Nations has undergone more than four decades of development. ${ }^{119}$ Its evolution can be divided into three major stages: (i) in the early decades, members focused on the consolidation of the fragile organization; (ii) in the aftermath of the Cold War, ASEAN expanded its membership and incorporated new issue areas of cooperation; (iii) following the 1997-1998 Asian financial crisis regional leaders re-examined ASEAN's direction, showing great determination to revitalize and strengthen the organization so as to pave the way for deeper regional cooperation. Numerous initiatives were introduced before ASEAN members made a concerted effort of

\footnotetext{
119 For a review of ASEAN's development, see among others Rodolfo C. Severino, “ASEAN Beyond Forty: Towards Political and Economic Integration," Contemporary Southeast Asia 29, no. 3 (2007): 406-23; Rodolfo C. Severino, Southeast Asia in Search of an ASEAN Community: Insights from the Former ASEAN Secretary-General (Singapore: Institute of Southeast Asian Studies, 2006); Chin Kin Wah, "Introduction: ASEAN Facing the Fifth Decade," Contemporary Southeast Asia 29, no.3 (2007): 395-405; Shaun Narine, "ASEAN in the Twenty-first Century: A Sceptical Review," Cambridge Review of International Affairs 22, no. 3 (2009): 369-86.
} 
community building which took the form of the Bali Concord II. ${ }^{120}$ This document envisioned the building of an ASEAN Community based on three pillars, namely political and security cooperation, economic cooperation and socio-cultural cooperation that are closely intertwined and mutually reinforcing. ${ }^{121}$ For the first time, ASEAN approached economic, political and security cooperation in a more integrated manner. ${ }^{122}$

Having recognized that the goal of building an ASEAN Community could not be achieved without strengthening ASEAN institutions, ASEAN Foreign Ministers at their $37^{\text {th }}$ Meeting (June 2004) agreed to work towards the development of an ASEAN Charter. ${ }^{123}$ The Document was expected to provide an enhanced institutional framework and confer a legal personality on the Organization. ${ }^{124}$ At $11^{\text {th }}$ Summit in 2005, ASEAN Leaders agreed to establish an Eminent Persons Group (EPG) to examine and provide practical recommendations on the directions for ASEAN and the nature of the ASEAN Charter and tasked the Ministers to form a High Level Task Force to draft the Document. ${ }^{125}$

\footnotetext{
${ }^{120}$ For example, Singapore Prime Minister Goh Chock Tong introduced in 2002 an initiative of building an ASEAN Economic Community. Indonesia proposed to build an ASEAN Security Community.

121 "Declaration of ASEAN Concord II (Bali Concord II)," ASEAN, October 7, 2003, http://www.aseansec.org/15669.htm.

${ }^{122}$ As Severino observed, a major reason that makes ASEAN fall short of its declared ambitions is the fact that its members have not pursued political cohesion and economic integration in an intertwined way. See Severino, "ASEAN Beyond Forty: Towards Political and Economic Integration,"414 -17.

${ }^{123}$ The plan was restated in subsequent ASEAN documents, including the Chairman's statement of the $10^{\text {th }}$ ASEAN Summit in November 2004; the Joint Communique of the $38^{\text {th }}$ ASEAN Ministerial Meeting in July 2005; the Chairman's Statement of the $11^{\text {th }}$ ASEAN Summit, December 2005.

124 "The Cebu Declaration on the Blueprint of the ASEAN Charter," ASEAN, January 13, 2007, http://www.asean.org/news/item/cebu-declaration-on-the-blueprint-of-the-asean-charter-cebuphilippines-13-january-2007.

125 "Chairman's Statement of the $11^{\text {th }}$ ASEAN Summit," ASEAN, December 12, 2005, http://www.aseansec.org/18039.htm.
} 
The HLTF had ten months, with a total of 13 meetings, in which to draft the ASEAN Charter. They started their work by following up the EPG's report which included, among others, ambitious proposals to legalize and strengthen ASEAN such as creating an ASEAN Union, membership suspension, possible change in decision-making, and dispute settlement procedures. ${ }^{126}$ The ASEAN Charter was finally completed with 13 chapters, covering various issues ranging from goals and objectives to institutional changes. However, it is widely agreed that what was reflected in the ASEAN Charter did not meet expectations inside and outside ASEAN. As Acharya has observed, the ASEAN Charter was a conservative document: the EPG's ambitious proposals were all discarded by the HLTF; core principles of state sovereignty and non-interference were upheld and consensus as a working rule remained unchanged. ${ }^{127}$ Perhaps the only sensitive issue in which collective interests appeared to triumph over national interests was in the establishment of an ASEAN Human Rights Body.

With the decision to establish a human rights body, ASEAN found a new consensus in dealing with a sensitive issue that had been considered a "taboo",128 in the organization's affairs and an obstacle in its external relations, particularly with Western countries. Externally, the Association as a whole - and its individual members - has consistently taken a similar stance in dealing with the human rights issue. ASEAN and its members have strongly rejected attempts by outsiders to intervene in regional and national affairs in the name of human rights. The political crisis in Myanmar in the late 1980s and early 1990s is one example. ${ }^{129}$

\footnotetext{
126 "Report of the Eminent Persons Group on the ASEAN Charter," ASEAN, December 2006, http://www.aseansec.org/19247.pdf.

${ }^{127}$ Acharya, Constructing a Security Community in Southeast Asia, 269-70.

128 Trung Thanh Nguyen, "The Making of the ASEAN Charter in My Fresh Memories," in The Making of the ASEAN Charter, eds. Tommy Koh, Rosario G. Manalo and Walter Woon (Singapore; Hackensack, NJ : World Scientific Pub. Co., 2009), 103.

129 The situation in Myanmar has been an obstacle between ASEAN and Western countries. See for example, Maria-Gabriela Manea, "Human Rights and the Interregional Dialogue between Asia and Europe: ASEAN-EU Relations and ASEM," The Pacific Review 21, no.3 (2008): 369-96;
} 
How to deal with the situation in Myanmar dominated relations between ASEAN and the West. However, the former did not approach the issue from a human rights perspective and saw Western calls to isolate and punish Myanmar as a challenge to ASEAN's doctrine of non-interference and regional autonomy. ${ }^{130}$

ASEAN's awareness of the need to coordinate a common position on human rights in the international arena increased as a result of the emergence of international discourse on human rights in the 1990s. At the 1993 World Conference on Human Rights, ASEAN members joined other Asian countries in adopting the Bangkok Declaration, highlighting Asia's differences in approaching human rights. ${ }^{131}$ They then collectively expressed this position in the Joint Communique of the $26^{\text {th }}$ ASEAN Ministerial Meeting in $1993 .^{132}$ Two fundamentals of the Bangkok Declaration were brought into the Joint Communiqué which reflected the major difference to the Western approach. First, ASEAN stressed the universality of human rights, affirming that human rights are interrelated and indivisible comprising civil, political, economic, social and cultural rights. ${ }^{133}$ These rights are of equal importance. Second, ASEAN emphasized the need to take cognizance of regional uniqueness, paying due regard for specific cultural, social, economic and political circumstances and of the fundamental principles in inter-state relations such as respect for national sovereignty, territorial integrity and non-interference in the internal affairs of

\footnotetext{
Joergen Oerstromem Moeller, "ASEAN's Relations with the European Union: Obstacles and Opportunities," Contemporary Southeast Asia 29, no. 3 (2007): 465-82.

${ }^{130}$ Acharya, Constructing a Security Community in Southeast Asia, 129.

131 "Bangkok Declaration," Asia-Pacific Human Rights Information Center, 29 March-2 April 1993, http://www.hurights.or.jp/archives/other_documents/section1/1993/04/final-declaration-ofthe-regional-meeting-for-asia-of-the-world-conference-on-human-rights.html.

132 "Joint Communiqué of the Twenty-Sixth ASEAN Ministerial Meeting," ASEAN, July 23-24, 1993, http://www.aseansec.org/3666.htm.

${ }^{133}$ Ibid., paragraph 16.
} 
states. ${ }^{134}$ The Joint Communiqué also mentioned for the first time that ASEAN would consider the establishment of a regional human rights mechanism. ${ }^{135}$

Intra-regionally, ASEAN avoided discussing human rights issues. As one leading analyst put it, upholding the principle of non-interference in each other's internal affairs with respect to human rights means members are encouraged to "refrain from criticizing the actions of a member government towards its own people, including violations of human rights."136 Vietnam's HLTF member Nguyen Trung Thanh also confirmed that ASEAN's avoidance of discussing human rights in its official meetings was a "tactful working way of nonintervention." 137 The issue of human rights was regarded as an internal issue for individual ASEAN states. Not criticizing the human rights records of others was seen as upholding the principle of non-interference.

ASEAN only made broader commitments to human rights as a consequence of the regional financial crisis in 1997-1998. In the 1998 Hanoi Plan of Action (HPA), it was asserted that ASEAN would "enhance exchange of information in the field of human rights freedoms of all peoples in accordance with the Charter of the United Nations, the Universal Declaration of Human Rights and the Vienna Declaration and Programme of Action." ${ }^{138}$ Indonesia played an important role in reorienting the regional discourse on human rights. Jakarta proposed building an ASEAN Security Community towards the promotion and protection of human rights in ASEAN and the creation of an ASEAN human

\footnotetext{
${ }^{134}$ Ibid., paragraph 17.

${ }^{135}$ Ibid., paragraph 18. On building a regional human rights mechanism, see Maznah Mohamad, "Toward a Human Rights Regime in Southeast Asia: Charting the Course of State Commitment," Contemporary Southeast Asia 24, no. 2 (2002): 230-51; Hao Duy Phan, "The Evolution Towards an ASEAN Human Rights Body," Asia-Pacific Journal on Human Rights and the Law, no.1 (2008): 1-13.

${ }^{136}$ Acharya, Constructing A Security Community in Southeast Asia, 72.

${ }^{137}$ Nguyen, "The Making of the ASEAN Charter in My Fresh Memories," 102.

138 "Hanoi Plan of Action,” ASEAN, December 15-16, 1998, http://www.asean.org/8754.htm.
} 
rights body. In the Vientiane Action Program 2004 (VAP), ASEAN committed to the promotion of human rights and obligations in very general terms. ${ }^{139}$

Writing in 2006, Rodolfo Severino identified several obstacles that needed to be overcome if ASEAN was to develop a common voice with the creation of an ASEAN-wide mechanism. Specifically, he stressed differences in the interpretation of the concepts, the approaches and practices among ASEAN members as sources of disagreement. ${ }^{140}$ Similarly, the EPG in their Final Report on the ASEAN Charter in December 2006 did not envision the creation of an ASEAN HRB. Rather, they simply suggested that "this worthy idea [the human rights mechanism] should be pursued further." 141 At that time, only some ASEAN leaders pushed the proposal. Philippines President Gloria Arroyo, acting in her capacity as the Chair of the $12^{\text {th }}$ ASEAN Summit (2006), insisted on the inclusion of a provision establishing a human rights mechanism in the draft Charter. ${ }^{142}$ Thai Prime Minister Surayud Chulanont also supported the idea. ${ }^{143}$ However, the proposal elicited little support from other ASEAN leaders. As a result, official documents released after the $12^{\text {th }}$ ASEAN Summit mentioned human rights only in very general terms. This meant, just before the HLTF convened its first meeting, there was still no consensus among ASEAN leaders on the possibility of an ASEAN HRB.

\footnotetext{
139 "Vientiane Action Programme," ASEAN, 2004, http://www.aseansec.org/ADS-2004.pdf.

${ }^{140}$ Severino, Southeast Asia in Search of an ASEAN Community, 151-54.

141 "Report of the Eminent Persons Group on the ASEAN Charter," ASEAN, December 2006, http://www.asean.org/archive/19247.pdf.

${ }_{142}$ Mely Caballero-Anthony, "The ASEAN Charter: An Opportunity Missed or One that Cannot Be Missed," Southeast Asian Affairs (2008): 81.

${ }^{143}$ The ASEAN Secretariat, "Record of the 2nd Meeting of the High Level Task Force on the Drafting of the ASEAN Charter," February 28, 2007.
} 


\section{Chronology of the negotiations}

Negotiations on the establishment of an ASEAN HRB took place in three phases. In the first phase, the HLTF had a preliminary exchange of views. In the second phase, it had intense deliberations on whether and when ASEAN should create a HRB. The third phase was devoted to discussion on possible forms and functions of the body. The HLTF was split in phases two and three. Participants from Indonesia, the Philippines, Thailand and Singapore strongly supported the initiative, while those from Vietnam, Laos, Cambodia, and Myanmar, if not explicitly opposed, were extremely reluctant. Deliberations did not lead to agreement. As a result, ASEAN Foreign Ministers had to intervene to reconcile divergent views of the HLTF members. They quickly decided to establish a HRB for ASEAN.

\section{Phase I: Preliminary exchange of views}

The Task Force members touched upon the issue of the proposed human rights body at their second meeting (Cambodia, from February 28 to March 1, 2007) when they exchanged views on the skeleton of the ASEAN Charter. However, there was no consensus on the issue and the majority of the HLTF members seemed to be very reluctant in discussing the proposal in detail. Records of the second meeting reveal that the Lao participant questioned whether ASEAN even needed a HRB. Myanmar's representative said that his leaders did not agree with the proposal and the Vietnamese participant preferred to discuss it later in the drafting process. Only the Philippines participant showed a more supportive attitude by initiating an enabling provision in the Charter for an institution related to human rights protection in ASEAN. Generally, the Task Force shared the view 
that the issue needed further discussion and was one where they should seek instructions from Ministers. ${ }^{144}$

On the sidelines of the ASEAN Ministerial Meeting Retreat (Siem Reap, Cambodia, March 1 and 2), the HLTF Chair - Rosario Manalo from the Philippines - submitted the first progress report to the Ministers and requested their instructions on ten points, including the one on a HRB. HLTF members were not allowed to attend the Foreign Ministers' discussion. Instead, the ASEAN Secretary-General worked as an intermediary. Notes, including a list of ten specific instructions, were prepared by the Secretary-General and sent to the HLTF. The final point on the list was the instruction by the Ministers for the HLTF to "include a draft provision on ASEAN Human Rights Commission as an organ." 145

The Task Force discussed the Ministers' decisions taken in Siem Riep at their third meeting (Manila, the Philippines, March 28-29, 2007). Records of this meeting show that, regarding the instruction to include a draft provision on the human rights commission, the Vietnamese representative proposed that the Terms of Reference (TOR) for the Commission should be developed before Foreign Ministers/Heads of States decided whether or not to create such a commission. ${ }^{146}$ He also added that a draft of the TOR would help facilitate subsequent deliberations. The Lao participant proposed that any human rights mechanism should only be a consultative body and that ASEAN should have a Declaration on Human Rights before setting up the mechanism. Myanmar's participant stressed the need for the HLTF to move cautiously. Meanwhile, participants from other ASEAN members focused on other instructions by Ministers. However, they took note of Vietnam's proposal on the TOR for the proposed commission.

\footnotetext{
${ }^{144}$ Ibid.

${ }^{145}$ Koh, "The Negotiating Process," 54.

${ }^{146}$ The ASEAN Secretariat, "Record of the third Meeting of the High Level Task Force on the Drafting of the ASEAN Charter," March 28-29, 2007, p. 29.
} 
The issue of a HRB was not discussed in detail in the three subsequent meetings - the fourth, fifth and sixth - which were held in Myanmar and Vietnam in April and in Malaysia in May 2007, respectively. It was not until the seventh meeting (Bali, Indonesia in June) that more substantive discussions took place. According to Tommy Koh, the HLTF spent two half-days, in a retreat format, discussing two separate issues: the enabling provision and the TOR for the proposed human rights commission. ${ }^{147}$ The Task Force members had a brief discussion on the need of the TOR when interpreting the Ministers' instruction on the enabling provision. ${ }^{148}$ Participants from Myanmar and Malaysia questioned if there was agreement among Ministers on the need for the TOR at their first meeting in Siem Riep. Meanwhile, participants from Laos, Cambodia and Vietnam shared the view that TOR should be worked out first, particularly the mandates and functions of the commission. Ministers would then decide whether to have an enabling provision on it in the Charter. ${ }^{149}$ Participants from the Philippines and Indonesia agreed to work on the TOR and the enabling provision at the same time. ${ }^{150}$ The HLTF then held a retreat to discuss the TOR before they had a long discussion with the four heads of the national human rights commissions with a view to getting more inputs for their next deliberations.

Koh also reported that in another retreat meeting to discuss the $\mathrm{TOR}^{151}$ the HLTF agreed that the terms of reference would specify the following:

(i) It would be inter-governmental in composition

(ii) It would not be a finger-pointing body

(iii) It would define human rights in an ASEAN context

\footnotetext{
${ }^{147}$ Koh, "The Negotiating Process," 57.

148 The ASEAN Secretariat, "Record of the seventh Meeting of the High Level Task Force on the Drafting of the ASEAN Charter," June 26-28, 2007, p.3.

${ }^{149}$ Ibid., 3-4.

${ }^{150}$ Ibid., 4.

${ }^{151}$ Discussions in the two retreat meetings on the TOR were not detailed in the Records of the HLTF meetings.
} 
(iv) It represents ASEAN's views at international forums, and

(v) It should have consultative status ${ }^{152}$

However, according to the Indonesian participant, the draft of the TOR for the ASEAN human rights Commission was not completed at the seventh meeting. ${ }^{153}$ Therefore, discussions on the TOR continued in the subsequent meetings.

\section{Phase II: Whether to establish an ASEAN Human Rights Body}

The HRB was "the most contentious issue" 154 at the eighth meeting (Manila, the Philippines, July 2007) where the HLTF had a heated debate on the enabling provision. There were divergent views on the need for the TOR in relation to the interpretation of the Ministers' instruction on the human rights commission. This was confirmed in the record of the eighth meeting. ${ }^{155}$ Those from Vietnam, Laos, and Cambodia preferred to present the TOR to the Ministers, emphasizing that the TOR should be improved, so it could be the basis for the Ministers to have final decision on whether or not to create such a body within ASEAN's organizational structure. However, ASEAN Secretary-General Ong Keng Yong and the Indonesian participant reaffirmed that there was no instruction from Foreign Ministers for the HLTF to work on the TOR. The Indonesian participant supported the discussion if this would help HLTF members have a better understanding of each other's views. The Thai participant said the HLTF should work on the enabling provision on a human rights commission as instructed. The Vietnamese representative was, however, the first to propose a formulation of the enabling provision as follows:

\footnotetext{
${ }^{152}$ Koh, 57.

${ }^{153}$ Dian Triansyah Djani, "A Long Journey," in The Making of the ASEAN Charter, eds. Tommy Koh, Rosario G. Manalo and Walter Woon (Singapore; Hackensack, NJ: World Scientific Pub. Co., 2009), 144.

154 Koh, 58.

${ }^{155}$ The ASEAN Secretariat, "Record of the eighth Meeting of the High Level Task Force on the Drafting of the ASEAN Charter," July 22-31, 2007.
} 
ASEAN may establish, as and when deemed necessary, consultative bodies, including the ASEAN Human Rights Organ. ${ }^{156}$

Participants from Singapore, Thailand, Malaysia, Indonesia, Laos, and Cambodia followed up with different formulations. The proposals from Laos and Cambodia were similar to that of Vietnam, suggesting that the creation of the human rights commission should be a future project and that it should only have consultative status. ${ }^{157}$ Myanmar's participant maintained his reservations, however, arguing that he needed to discuss with line ministries at home because this was a sensitive issue. Meanwhile, participants from Thailand and Indonesia were more supportive. Thailand's proposal was as follows:

\section{Article ....: ASEAN HRs Commission}

1. There shall be an ASEAN HRs Commission to promote the observance and protection of HRs in this region;

2. The mandate of such Commission shall be consistent with the purposes and principles of ASEAN and the UN Declaration on HRs and relevant international HRs treaties subscribed to by Member States.

3. Appropriate instruments shall be adopted. ${ }^{158}$

Indonesia's proposal had elements in common with the Thai suggestion. It also included suggestions on the mandate, rules and procedures and membership of the proposed body. ${ }^{159}$ The Chair and Brunei's participant meanwhile supported formulations proposed by Singapore and Malaysia which were described as seizing the middle ground. Malaysia's formulation was as follows:

\footnotetext{
156 Ibid.

${ }^{157}$ Laos proposed "ASEAN shall work toward establishing, as and when deemed necessary, a Human Rights body, with consultative status to promote and protect fundamental rights and freedom of the people of ASEAN." Cambodia suggested that "ASEAN may establish an ASEAN Human Rights Body, as and when necessary, to promote and protect human rights and fundamental freedom of the people in ASEAN." The ASEAN Secretariat, "Record of the eighth Meeting of the High Level Task Force on the Drafting of the ASEAN Charter," July 22-31, 2007, p. 132-3.

${ }^{158}$ The ASEAN Secretariat, "Record of the eighth Meeting of the High Level Task Force on the Drafting of the ASEAN Charter," July 22-31, 2007, p.132.

159 Ibid.
} 
ASEAN may establish such bodies/organs and commissions as may be required, including a body/organ/commission for the promotion and protection of human rights in ASEAN. ${ }^{160}$

Tommy Koh later described the situation where various formulations were put forward. He said the ten HLTF members were divided into three camps in the deliberations on the draft provision:

(i) Cambodia, Laos, Myanmar and Vietnam were opposed to the creation of an ASEAN Human Rights Commission;

(ii) Indonesia and Thailand were in favour; and

(iii) Brunei, Malaysia, the Philippines and Singapore occupied the middle ground. ${ }^{161}$

The HLTF then agreed to work toward a common draft of the enabling provision, by revising and regrouping the seven proposals. CLV and Indonesia/Thai proposals were revised as follows:

1. The CLV revised proposal: "ASEAN may establish an ASEAN Human Rights body at a time acceptable to all of us to promote and protect Human Rights and fundamental freedom of the people in ASEAN."

2. Indonesia/Thailand revised proposal: "ASEAN shall/may establish an appropriate Human Rights body/organ/institution/commission at a time acceptable/as and when necessary to all ASEAN Member States to uphold and protect human rights for promotion and protection of Human Rights in ASEAN. ",162

The biggest difference among HLTF members turned out to be the "timing" issue: when to create the HRB. Discussions went on with the wording of the provision. The Chair and Singaporean representative persuaded those from CLV

\footnotetext{
${ }^{160}$ Ibid. Singapore's formulation was that "ASEAN shall establish an appropriate ASEAN HR mechanism to promote the observance and protection of HRs and responsibilities, and fundamental freedoms of the people of ASEAN."

161 Koh, 58.

162 The ASEAN Secretariat, "Record of the eighth Meeting of the High Level Task Force on the Drafting of the ASEAN Charter," July 22-31, 2007, p.139.
} 
to use the word "shall" instead of "may" and to remove "at a time acceptable" arguing that the phrase conveyed a degree of reluctance. But CLV participants made no concessions. They even watered down the provision by suggesting that ASEAN "shall consider establishing..." The Lao representative added that "shall consider" was the most that the CLV could accept. ${ }^{163}$ Drawing on the two proposals of the CLV and of Thailand and Indonesia, the Singaporean participant offered a compromise, suggesting the following formulation:

ASEAN shall establish an ASEAN Human Rights body, at a time acceptable to all ASEAN Member States, to promote and protect the Human Rights and fundamental freedoms of the people in ASEAN. ${ }^{164}$

The Singapore participant also suggested that this proposal was on an ad referendum basis, which meant the proposal would be sent to the ASEAN Foreign Ministers for further consideration. Vietnam's representative emphasized the main difference of using the word "may" or "shall." Then all HLTF members agreed on adding the word "may" into Singapore's proposal. The HLTF finally adopted the following text, keeping both "shall/may" to show their lack of consensus:

ASEAN shall/may establish an ASEAN human rights body, at a time acceptable to all ASEAN member states, to promote and protect human rights and fundamental freedoms of the people of ASEAN. ${ }^{165}$

A new round of debate took place when the Chair announced that her Minister had rejected the ad referendum formulation and introduced the following new proposal:

\footnotetext{
${ }^{163}$ Ibid., 141.

164 Ibid., 143.

165 Ibid., 144.
} 
ASEAN shall establish an ASEAN Human Rights Commission to promote and protect Human Rights and fundamental freedom of the people of ASEAN. Participation in the Commission is open to Member States ready to do so. ${ }^{166}$

Together with the Philippines Foreign Secretary, Ministers from Singapore, Malaysia, and Indonesia reportedly also had a negative response to the ad referendum formulation. ${ }^{167}$ They argued that it fell far below what Foreign Ministers had agreed at Siem Riep. Regarding the new proposal introduced by the Philippines Minister, HLTF representatives from Malaysia, Indonesia, and Singapore were supportive, but it met with strong opposition from CLMV members. ${ }^{168}$ As Koh later recalled, "strong words were exchanged and emotions ran high." 169

The record of the eighth HLTF meeting reveals that CLMV participants shared a number of concerns regarding the new proposal by the Philippines Foreign Minister. ${ }^{170}$ One was the way the proposal was introduced. They saw it as an act of intervention by Ministers in the HLTF's work. The other was the possibility of dividing ASEAN when the Philippines Minister suggested ASEAN countries could choose to participate in the human rights commission when they were ready. The Cambodian representative feared that there would be some ASEAN members taking the lead and pushing the rest on the human rights issue. The Vietnamese representative said he would not stand for the proposal and stressed that agreement could not be reached without knowing what the commission was going to do. He said the HLTF still had time, and therefore the group should continue to work on the TOR. CLMV participants repeatedly asked the opposing group to spend more time to fully develop the TOR. They were

\footnotetext{
${ }^{166}$ Ibid. Originally bold and italics.

167 Koh, 59.

168 Ibid.

169 Ibid.

${ }^{170}$ The ASEAN Secretariat, "Record of the eighth Meeting of the High Level Task Force on the Drafting of the ASEAN Charter," July 22-31, 2007, p. 150.
} 
consistent on the issue. However, by the end of the day the HLTF could not bridge the gap between the two groups. ASEAN Secretary-General Ong Keng Yong came up with a new formulation, suggesting that it would help fill the vacuum:

As one of ASEAN's purposes and principles is to protect and promote human rights and fundamental freedom, ASEAN shall cooperate to establish a Human Rights body. ${ }^{171}$

The Vietnamese representative did not support the Secretary-General's proposal. Laos' participant suggested some improvements to the Secretary-General's proposal as follows:

In conformity with the purposes and principles of the ASEAN Charter related to the protection and promotion of Human Rights and fundamental freedoms, ASEAN shall cooperate to create an ASEAN Human Rights organ. $^{172}$

Some other HLTF members supported this draft, but as a group, the HLTF was unable to arrive at a consensus. This contentious issue was then referred to the Foreign Ministers for their decision. ${ }^{173}$ The second meeting of Foreign Ministers was convened on the morning of July 30, 2007. The HLTF submitted their second progress report to the Ministers, along with the first draft of the Charter and a request for guidance on the 14 points, including the provision on a human rights commission. ${ }^{174}$ On the request on the human rights provision, the Foreign Ministers decided:

(1) The HLTF to use the following text: "In conformity with the purposes and principles of the ASEAN Charter relating to the promotion and

\footnotetext{
${ }^{171}$ Ibid., 159.

172 Ibid.

173 Koh, 60.

174 The ASEAN Secretariat, "Secretary-General Summary from the AMM Retreat," July 30, 2007.
} 
protection of human rights and fundamental freedoms, ASEAN shall establish an ASEAN human rights body."

(2) HLTF to submit a TOR, but do not include it in the Charter. ${ }^{175}$

The question of whether or not to establish an ASEAN HRB was finally decided by Foreign Ministers at their second meeting. As Koh observed, the decision by ASEAN Foreign Ministers "was received by some of my colleagues with disbelief." 176 Even though Koh did not specify just who those HLTF members were, the Vietnamese HLTF member could be one given the fact that he consistently stressed for the completion of the TOR as the basis for the Foreign Ministers to have a final say on whether or not to establish the HRB. ASEAN Secretary-General Ong Keng Yong later confirmed that at this second meeting of ASEAN Foreign Ministers, Vietnamese Deputy Foreign Minister Le Cong Phung finally announced that Vietnam would go along with the decision on the condition that "there must be TOR, and the HRB should only have consultative status." 177 Ong Keng Yong also added that Phung's announcement settled the issue. ${ }^{178}$ Finally, consensus was reached on the creation of the HRB.

\section{Phase III: The TOR and functions of the HRB}

The HLTF did not have enough time to discuss the issue of the HRB at its ninth meeting (Singapore, August 24-26, 2007). Instead, it dominated the $10^{\text {th }}$ meeting (Chiang Mai, Thailand, September 10-14, 2007). At this meeting, the HLTF disagreed on three issues:

(i) Whether the Ministers had instructed the HLTF to draft the terms of reference; and

\footnotetext{
${ }^{175}$ ASEAN Secretary-General's Summary on "Decisions of ASEAN Foreign Ministers on the first draft of ASEAN Charter," AMM Retreat, July 30, 2007.

${ }^{176}$ Koh, 60.

177 The ASEAN Secretariat, "Record of the $10^{\text {th }}$ High Level Task Force Meeting on the Drafting of the ASEAN Charter," September 10-14, 2007, p. 26.

${ }^{178}$ Ibid.
} 
(ii) Whether the terms of reference should be completed before the signing of the Charter.

(iii) The proposal by CLMV of an additional paragraph to the HRs provision, clarifying the function of the HRB; ${ }^{179}$

The HLTF started their $10^{\text {th }}$ meeting with discussion on the agenda items. Participants from the Philippines, Thailand, Indonesia and Malaysia formed a group opposing the discussion of the TOR, making the argument that the HLTF was not mandated to discuss and complete it. ${ }^{180}$ Meanwhile, the CLMV participants wanted to settle the TOR first. The Vietnamese participant stressed that there must be a TOR and that the HRB should have only consultative status. This status should be reflected either in the TOR or in the Charter itself. ${ }^{181}$

The discussion was described as a deadlock. ${ }^{182}$ According to Koh, a working dinner was organized in order to facilitate a more relaxed discussion. ${ }^{183}$ However, this effort also failed. As Koh recalled, at the dinner "strong words were exchanged with one colleague threatening to pack his bag and go home... The dinner adjourned in a bad mood and without any common ground." ${ }^{184}$ The negotiation continued the whole morning of the next day with two opposing groups gathering in two different rooms. The Chair (Tommy Koh from Singapore) worked as facilitator, communicating between the two. The CLMV participants consulted among themselves. Then Myanmar's participant offered on behalf of the CLMV group an additional paragraph to the provision on the HRB:

\footnotetext{
${ }^{179}$ Koh correctly summarised the discussion, 62 .

${ }^{180}$ The ASEAN Secretariat, "Record of the 10th High Level Task Force Meeting on the Drafting of the ASEAN Charter," September 10-14, 2007.

${ }^{181}$ Ibid.

${ }^{182} \mathrm{Koh}, 62$.

${ }^{183}$ Ibid.

${ }^{184}$ Ibid., 63.
} 
This ASEAN Human Rights Body shall be of consultative nature and shall be operated in accordance with the Terms of Reference to be determined by the ASEAN Foreign Ministers. ${ }^{185}$

The Philippines participant rejected this proposal. She added that she did not understand what "consultative status" meant and said that the additional paragraph proposed by CLMV participants should only be regarded as a possible proposal rather than the HLTF's proposal. At the request of the Philippines participant, each of the CLMV representatives explained and defended their position. Myanmar's representative was of the view that human rights were the sticking point and if the HLTF could overcome this, they could have the Charter in time. He said step-by-step Myanmar had made compromises and the proposed additional paragraph was as far it could go. Cambodia's representative argued that if all members could not reach agreement on the TOR they had to have another paragraph relating to the HRB. Vietnam's representative stressed the need to uphold the principle of sovereignty - not accusing each other - as a basis for the HRB to have consultative status. He emphasized the sensitiveness of the human rights issue that compelled the HLTF to determine the TOR in order to go along with the proposed body. ${ }^{186}$ Laos' representative elaborated on what "consultative nature" of the human rights body meant. To him, the terminology composed of four "nos": no investigation, no monitoring, no finger pointing, and no country reporting. ${ }^{187}$

However, the Philippines representative did not yield. She threatened to withdraw from the discussion. Singapore's representative agreed with the additional paragraph but suggested taking out the phase "consultative nature" since the term meant different things to different people. He also proposed to discuss the ASEAN Secretariat's non-paper on possible elements in the TOR. The

185 The ASEAN Secretariat, "Record of the 10th High Level Task Force Meeting on the Drafting of the ASEAN Charter," September 10-14, 2007, p. 80.

${ }^{186}$ Ibid., 82.

${ }^{187}$ Ibid., 85. 
Indonesian and Malaysian participants proposed reporting to their Ministers the state of the HLTF discussion on this issue. CLMV participants then consulted among themselves again, but decided not to make any more concessions. They urged the other side to discuss and accept their proposal. According to Tommy Koh the final agreement was that both sides accepted a compromise consisting of two elements:

(i) The inclusion of an additional paragraph in the Charter on the Human Rights body that:

"The ASEAN human rights body shall operate in accordance with the terms of reference to be determined by the ASEAN Foreign Ministers";

And

(ii) An informal discussion on the ASEAN Secretariat's concept paper on "Possible Elements for Inclusion in the Terms of Reference of an ASEAN Human Rights Body." $" 188$

On the final day of the $10^{\text {th }}$ meeting, the HLTF had a preliminary discussion on possible elements of the TOR and agreed to include the additional paragraph on the HRB in the summary record of the $10^{\text {th }}$ meeting, together with three other questions for the Foreign Ministers' instruction:

(i) The nature of function of the human rights body.

(ii) Whether the HLTF had to draft TOR?

(iii) Should it be completed before the Charter? ${ }^{189}$

Foreign Ministers responded to these questions at their third meeting, held in New York in September 2007. The HLTF members were allowed to attend the discussions. The Ministers decided that the HRB should be located in Chapter IV of the proposed Charter, after ASEAN National Secretariats and before the

\footnotetext{
${ }^{188}$ Koh, 63.

${ }^{189}$ Koh, 62.
} 
ASEAN Foundation. They also endorsed the second paragraph as proposed without any revision and decided that the TOR could be a work-in-progress if it could not be completed in time. ${ }^{190}$ However, the Ministers did not touch upon the functions of the HRB. ${ }^{191}$

\section{A balanced option reached}

The controversy over the establishment of an ASEAN HRB was finally settled. The HLTF did not discuss the issue again in their final meetings. For the first time all of ASEAN's members had agreed to create an arrangement to address human rights issues, marking the end to one "taboo" in their inter-state relations. According to the Vietnamese HLTF member, the enabling provision in the Charter was the "best balanced option that may satisfy both those advocating for the establishment of an ASEAN Human Rights Body and those who still have reservations with this idea." 192 This "balanced option" was codified in Article 14 of the ASEAN Charter which reads:

1. In conformity with the purposes and principles of the ASEAN Charter relating to the promotion and protection of human rights and fundamental freedoms, ASEAN shall establish an ASEAN human rights body.

2. This ASEAN human rights body shall operate in accordance with the terms of reference to be determined by the ASEAN Foreign Ministers Meeting.

The above "balanced option" regarding the creation of an ASEAN HRB reflects to some extent the common knowledge among ASEAN members that

\footnotetext{
${ }^{190}$ The ASEAN Secretariat, "Decisions of the ASEAN Foreign Ministers on the third progress report of the High Level Task Force (HLTF) on the Drafting of the ASEAN Charter," September 27, 2007.

${ }^{191}$ In a diplomatic note sent to the ASEAN Secretary-General dated October 1, 2007 - in response to his draft paper on the decisions of the ASEAN Foreign Ministers on the Third Progress Report the Philippines Secretary of Foreign Affairs confirmed that there was no consensus among the Ministers on the issue that the ASEAN Human Rights Body shall be only a consultative body. The ASEAN Secretariat, Annex 5 dated October 1, 2007.

${ }^{192}$ Nguyen, "The Making of the ASEAN Charter in My Fresh Memories," 123.
} 
now it was time to substantiate regional cooperation in even the most sensitive issue areas. Though the Vietnamese HLTF member did not totally adopt the idea of the HRB - as the chronology shows - he appeared proactive in discussing the proposal. More importantly, internal documents show that there was a change in Vietnam's preferences: prior to the drafting process, Vietnam did not support the creation of the HRB. A memo prepared by the ASEAN Department of the Vietnamese Foreign Ministry specifically for the first HLTF meeting recommended Vietnam's position on the proposed HRB should be as follows:

We propose that a human rights mechanism should not be created since ASEAN's organizational structure has been already overlapped. We should follow the EPG recommendations to hold regular consultations and interactions between ASEAN organs and civil society organizations and regional human rights mechanisms. All ASEAN organs are responsible for the protection and promotion of human rights. ${ }^{193}$

However, after the seventh HLTF meeting, the establishment of such a HRB was no longer a big problem for Vietnam. As MOFA reported afterwards:

Throughout the deliberations, ASEAN members initially agreed on how to approach human rights issue intra-regionally. Now the establishment of a regional human rights body is not a big controversy. What is more controversial is when to create it and what the body is going to do. On the latter, the HLTF generally agreed on the first draft of the TOR for ASEAN Human Rights body. However, this is just the first step because the negotiation is going on and of complicated nature. The Draft of the TOR must be completed at the next meeting in Manila before being submitted to the Ministers at the $40^{\text {th }}$ AMM. ${ }^{194}$

On the surface it seemed that the activist members had successfully persuaded their hesitant Vietnamese counterpart to go along with their initiative. So, was this a case of persuasion? A persuasion explanation for Vietnam's

${ }^{193}$ MOFA ASEAN Department Memo prepared for the first Meeting of the HLTF on drafting ASEAN Charter, January 2007, p. 3.

${ }^{194}$ MOFA ASEAN Department Report "On the Results of the seventh Meeting of the High Level Task Force on the Drafting of the ASEAN Charter," July 2007, p. 3. 
endorsement of the initiative would be that the Vietnamese HLTF member through the deliberations assessed the intention and arguments of the advocates as trustworthy: the establishment of the HRB was not to intervene in the internal affairs of individual members. Rather, it was an effort to translate words into deeds at a time when all ASEAN members agreed to make human rights protection and promotion an objective in the ASEAN Charter. While the chronology of the negotiation provides insights into how the Vietnamese HLTF member took part in the negotiations, why Vietnam changed its position remains unclear. To explain this shift, we need to look more closely at debates within the Vietnamese bureaucracy to see how the Vietnamese representative assessed the intention and arguments of activist ASEAN members.

\section{Persuasion as an explanation}

A persuasion explanation for Vietnam's agreement with the HRB would be that the Vietnamese Task Force member throughout the deliberations gradually came to recognize that the creation of the HRB was necessary if ASEAN was going to substantiate cooperation toward building an ASEAN Community and that it would not target any particular ASEAN member. Rather, it would be seen as an effort by ASEAN to build a common voice in dealing with human rights issue both internally and externally.

This section starts with a description of the working environment in the drafting process of the ASEAN Charter and the characteristics of the participants to see to what extent institutional and individual features are conducive to persuasion. It then examines how Vietnam assessed the intentions and arguments for the HRB to see if it was persuaded by other advocates to take on regional responsibilities in this area. Johnston suggests that an ideal environment for persuasion would have the following features: a small number of participants with a couple of actors recognized as authoritative (the information they provide is 
more convincing); deliberation as mandate and consensus as the decision-making rule; the actor is a novice with few ingrained attitudes toward the issue in question and he/she is relatively autonomous from the principal.

In this case, the working environment in the drafting process of the ASEAN Charter and the characteristics of the Vietnamese participants do not appear to be conducive to persuasion. First, the drafting process was a negotiation - arguably conducive to social influence instead. As mentioned in chapter three, negotiations over the distribution of benefits would not give an actor much autonomy from his/her principal and as a result he/she cannot make decision on their own. This situation makes it more difficult for an actor to be persuaded. This is true in the negotiations on the HRB. The Vietnamese representative in the negotiation did not enjoy much freedom to decide. As a working procedure and given the sensitiveness of human rights, he had to report to and seek instructions from the Foreign Minister.

Second, by the time the ASEAN Charter was being drafted, Vietnam was not a novice in ASEAN. Rather, its representative had long been involved in ASEAN affairs and he was seen to be an equal with counterparts from other states in terms of negotiation skills. Third, an ingrained attitude toward human rights caused lingering fears of intervention on the part of the Vietnamese. All these factors had significant impacts on Vietnam's assessment of intentions and arguments by advocates.

\section{Working environment}

\section{The drafting of ASEAN Charter as a negotiation}

The process of drafting the ASEAN Charter was essentially a negotiation among veterans of ASEAN over a wide range of issues. The Thai participant, Pradap Pibulsonggram, acknowledged that the HLTF members "began the 
drafting process as familiar faces to one another, as most of us knew each other well through our years of interaction in ASEAN circles or our postings in other parts of the world." 195 Indeed, HLTF members from ASEAN newer members were also experienced officials with a long involvement in ASEAN affairs. The Vietnamese HLTF member had been involved in ASEAN affairs since the early 1990s when the country moved to join the group. Thus he was no longer a novice in the working environment of the drafting process. Laos' participant also had a rich experience of working on ASEAN with nine years serving as ASEAN senior official and took part in many negotiations since $1998 .{ }^{196}$ Therefore, all members of the Task Force had a deep understanding of ASEAN. Long involvement and frequent face-to face interactions helped the HLTF members know each other well as well as the concerns of their respective governments. ${ }^{197}$

The characteristics of the Vietnamese representative and the like-minded members of CLMV group were best described by ASEAN Secretary-General Ong Keng Yong. To him, the drafting process was a negotiation among a group of "equal members":

The striking feature of the HLTF's deliberations over almost one year is the proactive and, occasionally, competitive roles of the representatives from CLMV. They pushed for their respective formulation of words, cajoled other member states' representatives to accept their concern about the unbridled future direction of ASEAN, and handled the reactions to their negotiation tactics in a manner reminiscent of the Ramayana drama on stage: slow and steady, and unyielding on the fundamentals. The strategic vision for ASEAN and the political acumen displayed by the respective CLMV Leaders in managing the ASEAN agenda was digested by the CLMV members on the HLTF. Yet, these drafters did not want to

\footnotetext{
195 Pradap Pibulsonggram, "The Thai Perspective," in The Making of the ASEAN Charter, eds. Tommy Koh, Rosario G. Manalo and Walter Woon (Singapore ; Hackensack, NJ: World Scientific Pub. Co., 2009), 87.

${ }^{196}$ Bounkeut Sansomak, "A New Turning Point in the Relations among the Southeast Asian States," in The Making of the ASEAN Charter, eds. Tommy Koh, Rosario G. Manalo and Walter Woon (Singapore ; Hackensack, NJ: World Scientific Pub. Co., 2009), 159.

${ }^{197}$ Pibulsonggram, "The Thai Perspective," 87.
} 
miss the opportunity to stamp their own imprimatur on such an important document like the ASEAN Charter. They clearly impressed all involved in the process that ASEAN is a collective body where each and every member state has a stake, a voice and a political wallop (to be used judiciously vis-à-vis fellow members when needed). To me, this display of dexterity and diplomacy means that ASEAN has come of age, as a grouping of equals, and it coincided with the timely establishment of the ASEAN Charter. ${ }^{198}$

Ong was clearly impressed with the prominence and confidence of HLTF members from CLMV in the negotiations. Indeed, as the chronology shows, the Vietnamese participant proactively engaged in the deliberations, navigating the drafting process in a way that he believed would best serve his national interests. Regarding the HRB, what he expressed in the negotiation was, if not an outright rejection of the proposal, the view that Vietnam was not ready for such an arrangement at the time of drafting the ASEAN Charter. More specifically, he wanted to know exactly what function and form the proposed HRB would take before considering whether to go along with it. He was the first to raise the idea of the TOR and later proposed his own formulation on the enabling provision on human rights. Together with CLM participants, he persuaded his ASEAN counterparts to accept their concerns and to make more concessions. The discussion of the HLTF at the $10^{\text {th }}$ meeting was a case in point. At that meeting, the CLMV participants were successful in persuading participants from old ASEAN members to discuss the TOR of the HRB, even without a clear mandate from Foreign Ministers.

During the drafting process Task Force members worked under tremendous time constraints and considerable pressure because of divergent positions, national interests and the drafting deadline. ${ }^{199}$ In a negotiation like the drafting process where there were high expectations of, and an urgent call for,

\footnotetext{
198 Yong, "At Close Quarters with the Drafting of the ASEAN Charter," 113.

199 Bounkeut Sansomak, "A New Turning Point in the Relations among the Southeast Asian States," 162.
} 
ASEAN members to take on regional responsibilities, all HLTF members had to think hard about how best to balance their national interests and that of the wider region. Most members agreed that the climax of the entire process came at the eighth HLTF meeting. This was the longest meeting (lasting for eight days) and the Task Force was split when it came to the issue of the HRB. As the Brunei representative observed, the pressure of drafting became "demanding and tense" as they dealt with the article referring to the establishment of the ASEAN HRB. ${ }^{200}$ He added that "of all our debate, this [human rights body] was the most explosive and tense of all." The negotiation on the HRB, in the words of Kao Kim Hourn, reflected a struggle among ASEAN members on how to balance "domestic political pressures" and "a new layer of regional responsibilities."201 The Indonesian representative also stressed the difficulty in balancing national interests and managing broader expectations. He had to take into account, among others, "the interests of Indonesia's stakeholders with regional realities."202

Vietnam's initial preference was clear: it preferred not to have a regional HRB. Rather, it wanted to hold regular consultations and interactions on the issue. During the negotiations, the Vietnamese representative implied that Vietnam was not ready for such arrangement at the time of the drafting process. However, since the proposed HRB was an item on the agenda, he had no choice but to participate in the deliberations. On the one hand, there was fear on the part of the Vietnamese representative that if he did not take part in the process, advocates for the HRB would take the lead, setting the rules and others would have to follow. The fear was expressed by the CLMV group at the eighth HLTF in response to the Philippines proposal. Therefore, the Vietnamese participant had to engage in the

\footnotetext{
${ }^{200}$ Pengiran Dato Paduka Osman Patra, "Heart Labour," in The Making of the ASEAN Charter, eds. Tommy Koh, Rosario G. Manalo and Walter Woon (Singapore; Hackensack, NJ: World Scientific Pub. Co., 2009), 7.

${ }^{201}$ Kao Kim Hourn, "A Personal Reflection," in The Making of the ASEAN Charter, eds. Tommy Koh, Rosario G. Manalo and Walter Woon (Singapore; Hackensack, NJ: World Scientific Pub. Co., 2009), 154.

${ }^{202}$ Dian Triansyah Djani, “A Long Journey,” 144.
} 
deliberations in order to control the process of the creation of the HRB and to set the rules that would be in Vietnam's interests if the body were created. ${ }^{203}$ On the other hand, engaging in the HRB deliberations was also a way to show that Vietnam had no fears about touching upon this sensitive issue. ${ }^{204}$ Raising the idea of the TOR therefore could be seen as killing two birds with one stone: it was a tactic to try and delay the establishment of the body and set the rules for its future operation if it were created, and at the same time it let Vietnam show that it was not trying to block the process. Engagement in the HRB deliberations, however, did not mean Vietnam had already agreed with the creation of the HRB.

Another crucial point in the drafting process of the ASEAN Charter was that consensus as decision rule was often challenged. Ong Keng Yong reported that, from time to time, he had to intervene "to urge consensus after prolonged debates on specific issues or particular forms of words." 205 The Malaysian HLTF member painted a more detailed picture:

"Negotiation through the 13 meetings held by the HLTF was not without tension, occasional outburst of emotions or dramatic moments. The absence of "undue pressure" did not mean the complete absence of "threats" exhibited by some members from time to time. Such conduct or negotiating techniques reflected the burden held by the HLTF members in protecting their respective national interest pertaining to key provisions in the Charter. The older ASEAN member states namely Indonesia, Malaysia, the Philippines, Singapore and Thailand even had to counter the notion of being seen to be "too generous" in conceding to the CLMV (Cambodia, Laos, Myanmar and Vietnam) member states on various critical and sensitive issues in the Charter."206

\footnotetext{
${ }^{203}$ Interviews by author in Hanoi, January 10, 2012.

${ }^{204}$ Ibid.

205 Yong, 112.

206 Tan Sri Ahmad Fuzi bin Abdul Razak, "Facing Unfair Criticisms," in The Making of the ASEAN Charter, eds. Tommy Koh, Rosario G. Manalo and Walter Woon (Singapore; Hackensack, NJ: World Scientific Pub. Co., 2009), 21.
} 
Violation of the consensus principle thus caused tensions among all members of the Task Force. For example, the Philippines participant in response to a CLMV proposal of an additional paragraph to the enabling provision said she was shocked and felt she was being coerced rather than being persuaded. ${ }^{207}$ Meanwhile, Laos' representative described the negotiations as sometimes tense and forceful, though amity and mutual respect prevailed. ${ }^{208}$

\section{Agent Autonomy}

The nature of a negotiation in which participants had to protect their national interests and the sensitiveness of the issue negotiated - the human rights issue - did not allow the Vietnamese representative much autonomy of action or some "degree of free choice" as theory suggests would be the case for an instance of persuasion. The chronology shows that the ASEAN Ministers had to intervene three times to get a final decision on the HRB. The Vietnamese HLTF member was no exception. While the policy-making process at the MOFA is increasingly decentralized and members of the ASEAN Department play the key role in shaping the country's policy on ASEAN issues, the Vietnamese participant still had to directly report to and receive instruction from the Foreign Minister about any progress with the negotiations. Being an expert on ASEAN affairs and serving as Vietnam's Senior Official for ASEAN, Nguyen Trung Thanh was in a more advantageous position to put forward policy recommendations. ${ }^{209}$ The idea of the TOR was his own. ${ }^{210}$ However, the sensitive nature of the human rights issue in Vietnam's external relations ${ }^{211}$ also required the involvement of various MOFA departments such as the Department of International Organizations and the Department of International Treaties and Laws and other government agencies

${ }^{207}$ The ASEAN Secretariat, "Record of the $10^{\text {th }}$ Meeting of the High Level Task Force on the Drafting of the ASEAN Charter," September 10-14, 2007, p. 87.

${ }^{208}$ Bounkeut Sansomak, 162.

${ }^{209}$ Interview by author in Hanoi, December 29, 2011.

${ }^{210}$ Interview with an official from ASEAN Department, January 10, 2012.

${ }^{211}$ Vietnam has the National Committee for Human Rights. 
such as the Ministry of Public Security and the Ministry of Defence. ${ }^{212}$ Therefore, during the negotiations the Vietnamese HLTF member had to consult with multiple agencies regarding the substance of the TOR. ${ }^{213}$

\section{Agent Properties}

The Vietnamese entered the negotiations with a deeply held attitude toward human rights: the issue has long been perceived as being hijacked by Western countries $^{214}$ and a number of hostile forces ${ }^{215}$ to intervene in the country's internal affairs with a view to implementing the so-called "peaceful evolution." ${ }^{216}$ Regarding the HRB, Ong Keng Yong reported to the Task Force that in their first meeting in Siem Riep in March 2007 the Vietnamese Foreign Minister said it had a problem with human rights because "it is being used as an excuse to intervene in our internal affairs." 217 During the HLTF negotiations, in addition to the fear the body could have monitoring functions as mentioned above, internal Vietnamese documents reveal that there was also concern about the possibility that the body would be manipulated if it were allowed to receive foreign financial support. ${ }^{218}$ Vietnam also wanted clarification about the body's

\footnotetext{
${ }^{212}$ MOFA ASEAN Department Report "On the Result of the seventh Meeting of the High Level Task Force on the Drafting of the ASEAN Charter," July 2007, p. 4.

${ }^{213}$ After the eighth HLTF meeting, at home there was a consultation among the HLTF members with representatives from various MOFA departments and other government bodies on the possible elements of the TOR.

${ }^{214}$ Mainly the United States.

${ }^{215}$ See "White Book on Vietnam's Achievements in the Protection and Promotion of Human Rights," Vietnamese Foreign Ministry, 2005, http://www.mofa.gov.vn/en/ctc_quocte/ptklk/nr040819162124/ns070206102551.

${ }^{216}$ Peaceful evolution is a defined threat to Vietnam's socialist regime. In particular, it refers to a plot purportedly carried out by the United States with a view to undermining and eventually eliminating socialism in Vietnam. For a detailed analysis of Vietnam's perception of peaceful evolution and its impacts on the pace and scope of the country's integration, see Elliot, Changing Worlds, 163-66; 175.

${ }^{217}$ The ASEAN Secretariat, "Record of the eighth Meeting of the High Level Task Force on the Drafting of the ASEAN Charter," July 22-31, 2007, p. 125.

${ }^{218}$ MOFA ASEAN Department Memo entitled "Recommendations on Our Positions in Dealing with the Issue of the Establishment of ASEAN Human Rights Body in the ASEAN Charter in the Preparation for the ninth HLTF Meeting on the Drafting of the ASEAN Charter," August 2007, p. 4.
} 
possible additional tasks and about the vague role possibly anticipated for the ASEAN Secretary-General. ${ }^{219}$

This ingrained attitude or perceived threat of intervention under the name of human rights among the Vietnamese has been developed and consolidated through the process of the country's integration into the international community since the early 1990s. First, it was the Western countries that placed human rights as a conditionality in the process of normalization of diplomatic relations with Vietnam. For example, the EU included specific provisions on human rights protection and promotion in the 1995 EU-Vietnam Framework Agreement. ${ }^{220}$ Similarly, in Vietnam-US relations, annual dialogues on human rights started even before the two countries normalized diplomatic relations in $1995 .^{221}$ Therefore, defending against outside pressure and intervention in the guise of human rights has been considered a long political struggle - a struggle that would intensify as Vietnam expanded and deepened its relationship with countries with different political system, especially the United States. ${ }^{222}$

Throughout the 1990s and in the early 2000s Vietnam adopted a largely reactive posture on the human rights issue. Since joining in ASEAN in 1995 Vietnam has tried to delay the establishment of a human rights body for ASEAN. ${ }^{223}$ For example, in a talking point on "Democracy and Human Rights" prepared for the $33^{\text {rd }}$ ASEAN Ministers' Meeting (Thailand, 2000), Vietnam was of the view that:

\footnotetext{
219 Ibid.

${ }^{220}$ MOFA Department of International Organization Research Project "On the Issue of Democracy and Human Rights in International Relations and in Vietnam's External Relations," (2003), p. 67.

${ }^{221}$ By 2010, the two sides held their $13^{\text {th }}$ Dialogue. Other bilateral dialogues on human rights have also been held with the EU, Australia, Norway, Sweden and Switzerland.

${ }^{222}$ MOFA Department of International Organization Research Project "On the Issue of Democracy and Human Rights in International Relations and in Vietnam's External Relations,” p. 67

${ }^{223}$ MOFA ASEAN Department Memo entitled "Recommendations on Our Positions in Dealing with the Issue of the Establishment of ASEAN Human Rights Body in ASEAN Charter in the Preparation for the ninth HLTF Meeting on the Drafting of the ASEAN Charter," August, 2007, p. 2.
} 
It is of primary importance that we cannot allow the acts by several countries to use democracy and human rights as the pretext for interfering with the internal affairs of other countries. It should be stressed that respect for sovereignty and non-interference in each other's internal affairs are the most fundamental principles of international relations. On the proposed establishment of an ASEAN Human Rights mechanism, due to the diversity and the current regional situation, it is not the right time to establish an ASEAN human rights mechanism; many of the countries in the region do not yet have a national human rights body to coordinate activities in this area. However, we could consider continuing exchanges of views on this issue in order to gain a better understanding and form a common voice to preserve the fine values of Southeast Asia and Asia. What is also important is that at the moment ASEAN should concentrate its efforts on addressing the consequences of regional crisis, recovering and sustaining economic growth, eliminating hunger and alleviating poverty with a view to ensuring the most fundamental and pressing human rights, that is the right to development and prosperity. ${ }^{224}$

It was not until recently that Vietnam changed its posture, from reactive to proactive, in dealing with the human rights issue. In 2005, Vietnam published the White Book on Vietnam's Achievements in the Protection and Promotion of Human Rights, expressing for the first time its official position and showing its preparedness for dialogues with all concerned countries, international and regional organizations on the issue. ${ }^{225}$ This proactive posture was then confirmed at the Xth National Congress of the Communist Party of Vietnam held in 2006:

\footnotetext{
${ }^{224}$ MOFA ASEAN Department Talking points "On Democracy and Human Rights" prepared for the $33^{\text {rd }}$ AMM, Bangkok, July 20-29, 2000.

${ }_{225}$ It was observed that the essentials of the Joint Communique of the $26^{\text {th }}$ ASEAN Ministers' Meeting in 1993 were echoed in the 2005 White Book: Vietnam takes a comprehensive approach to human rights and stresses the importance of the country's specifics in protecting and promoting human rights. It affirms that the protection and promotion of human rights are primarily the responsibility of the State and emphasizes economic and social process as the foundation for the promotion and protection of human rights. As Severino observed in 2006 in the human rights area ASEAN newer members are now at the place where old members were in the 1990s. See Severino, Southeast Asia in Search of an ASEAN Community, 148-54.
} 
To proactively participate in the common struggle for human rights. To stand ready for dialogues with concerned countries, international and regional organizations on human rights issues. To be determined to foil all plots and attempts to distort and abuse "democracy", "human rights", "ethnicity", and "religion" issues expecting to intervene into the internal affairs, infringing Vietnam's independence, sovereignty, territorial integrity, security, and political stability. ${ }^{226}$

Regarding the ASEAN HRB, this proactive posture was articulated by MOFA as follows:

When the ASEAN human rights body is created we should participate in its activities in a proactive manner. At the same time, we should actively contribute to developing an ASEAN Declaration of Human Rights which includes not only human rights norms enshrined in UN Conventions but also Asian values and norms, and ASEAN identity. We should be wellprepared to develop our persuasive arguments against the Western posture on the issue. ${ }^{227}$

However, the changed posture does not necessarily lead to change in the ingrained attitude on the issue, particularly toward the creation of a regional HRB. During the negotiations, together with CLM participants, the Vietnamese participant showed that he would not easily yield on this fundamental issue. Deliberations on the TOR at the $10^{\text {th }}$ HLTF meeting clearly confirmed this point, when the Vietnamese Task Force member stressed that he could only go along with the proposed HRB as long as the TOR was worked out and that the body would only have consultative status.

In sum, of all the conditions conducive for persuasion, only one - small membership - was present during the drafting process of the ASEAN Charter.

\footnotetext{
226 "Documents of the Tenth National Congress of the Communist Party of Vietnam," Communist Party of Vietnam, 2006,

http://chinhphu.vn/portal/page/portal/chinhphu/NuocCHXHCNVietNam/ThongTinTongHop/noid ungvankiendaihoidang?categoryId $=10000715 \&$ articleId $=10038386$.

${ }^{227}$ MOFA ASEAN Department Research Project "On the Prospects of ASEAN in the First Two Decades of the $21^{\text {st }}$ Century: Implications and Vietnam's Strategy," (2008), 80.
} 
Vietnam's HLTF member was not a novice in ASEAN affairs. Being confident and equal to others in terms of negotiation skills made it difficult for him to yield to others' arguments. The tight schedule of the negotiation, the pressure felt when activist members wanted to move faster, rather than in a pace comfortable to all, and the sensitive nature of the issue caused concern and even fear on the part of the reluctant members. This working environment did not facilitate flexible cognition among reluctant members or give them some degree of choice when it came to assessing the advocates' intentions and arguments.

\section{Assessing intentions of the advocates}

How the Vietnamese HLTF member judged the intentions of the activist members and the trust worthiness of their message needs to be examined in a broader context of Vietnam-ASEAN relations in which struggle and cooperation are seen by the former as the two aspects of the relationship. In general, $\mathrm{Vu}$ Khoan elaborated these two sides of the same coin as follows:

[On our part] we always wish and determine to promote cooperation in the principles of equality and mutual interests. But at the same time, we resolutely struggle against acts of encroaching upon Vietnam's independence, sovereignty, territorial integrity, and national interests. Rather than retarding cooperation this struggle is carried out with a view to promoting cooperation in a more effective manner. ${ }^{228}$

Expanding and deepening the Vietnam-ASEAN relationship has unfolded along these lines. A MOFA review of the first five years of Vietnam's participation in ASEAN concluded that one of the major lessons for Vietnam was

\footnotetext{
${ }^{228}$ Vũ Khoan, "Thành tựu trong lĩnh vực Đối ngoại qua 20 năm Đổi mới [Achievements in external relations over 20 years of renovation]," in Chính sách Đối ngoại Việt Nam: 1975-2006 [Vietnamese foreign policy, 1975-2006], ed. Nguyễn Vũ Tùng (Hanoi: Học viện Quan hệ Quốc tế, 2007), 425. Managing well between cooperation and struggle in international relations was one among the four operational guidelines set forth in the Resolution of the Third Plenum of the Central Committee of the Communist Party of Vietnam adopted in June 1992.
} 
to resolutely implement this strategy of struggle and cooperation. ${ }^{229}$ The aspect of struggle in Vietnam-ASEAN relations in the first ten years of participation could be seen in Vietnam's efforts to defend and uphold ASEAN's core principles in response to radical initiatives proposed by some old ASEAN members. In the late 1990s, Vietnam saw a tendency among some ASEAN members to relax and change the organization's core principles and to drive it in a way that was contradictory to common interests. ${ }^{230}$ For example, the initiative of "flexible engagement" proposed by Thailand and supported by the Philippines was seen as contrary to the principle of non-interference that ASEAN had upheld for so long. Flexible engagement failed because of the strong opposition from the rest of ASEAN's members. Vietnam considered its success in the struggle to uphold ASEAN's core principles as one of its most important achievements. The review of the first five years of Vietnam's participation stated that:

Vietnam has actively participated in the struggle to uphold the Association's core principles, especially consensus and non-interference in internal affairs. In the aftermath of the 1997 financial crisis, Thailand took the advantage of the division among ASEAN, particularly the difficult situation in Indonesia - once the leading member in ASEAN - to propose the initiative of "flexible engagement" at the $38^{\text {th }}$ AMM (7/1998) which was essentially aimed to change the principle of non-interference in internal affairs. Only the Philippines supported the initiative. Other ASEAN members rejected it outright. Although the initiative was a failure, Thailand pushed forth ASEAN Troika in order to materialize the initiative. In response, Vietnam and other ASEAN members firmly upheld the noninterference principle if ASEAN Troika was to be created. As a result, ASEAN Troika would only be constituted as an ad hoc body as and when it is necessary with the consensus of all ten ASEAN Foreign Ministers. It is not a decision-making body. Rather, it is a body to support and assist the ASEAN Foreign Ministers. ASEAN Troika will operate in accordance with consensus and non-interference principles. ${ }^{231}$

\footnotetext{
${ }^{229}$ MOFA ASEAN Department Research Project on "The First Five Years of Vietnam's Participation in ASEAN: Achievements, Challenges and Prospects," (2001), 112.

${ }^{230}$ Ibid., 13.

${ }^{231}$ Ibid., 61.
} 
From a Vietnamese perspective, this struggle has its roots in the differences among ASEAN members in terms of history, culture, level of economic development, political systems and divergent national interests. On the one hand, these differences "are the main obstacle for ASEAN members to achieve substantive cooperation in sensitive issue areas, including human rights." 232 On the other hand, these differences "require sympathy, mutual respect and understanding among ASEAN members if they are to promote regional cooperation and to ensure the solidarity and unity within the Organization." 233

The spirit of struggle and cooperation can also be found in the preparation for Vietnam's participation in the drafting of the ASEAN Charter, however with a softened tone regarding the struggle aspect:

We should actively participate in the drafting process of ASEAN Charter in order to chart out the Organization's future orientation; to increase the effectiveness of regional cooperation; to consolidate regional solidarity and unity on the basis of firmly holding the existing goals, objectives and principles; to guard against acts by some of ASEAN members which may have negative implications so as to ensure the development of ASEAN would be in our interests. ${ }^{234}$

During the negotiations on the HRB, the biggest difference among activist and reluctant members was on the "timing" of the creation of the body. While participants from the activist group pushed for the immediate creation of the $\mathrm{HRB}$, the Vietnamese representative preferred an incremental approach: first developing ASEAN norms on the protection and promotion of human rights, including an ASEAN Declaration on Human Rights, and second establishing a HRB as a step to implement the Declaration. The different approaches were summed up by the Vietnamese HLTF member in the report of the seventh meeting:

\footnotetext{
${ }^{232}$ Ibid., 11.

${ }^{233}$ Ibid., 109.

${ }^{234}$ MOFA ASEAN Department Report "On Ten Years of Vietnam's Participation in ASEAN," (2005), 12.
} 
The most controversial issue now is the roadmap of implementation: Indonesia, Malaysia, the Philippines and Thailand want to create the human rights body first, by including an enabling provision on human rights body in the ASEAN Charter, then develop concepts or adopt an ASEAN Declaration on Human Rights. The remaining, including Vietnam, Laos, and Cambodia, while in principle can agree on the creation of the human rights body, want to slow down the process through developing ASEAN norms on the promotion and protection of human rights, including the adoption of an ASEAN Declaration on Human Rights, before creating the human rights body. ${ }^{235}$

Therefore, the Philippines' strong support for the proposed HRB at the eighth HLTF meeting was seen by the Vietnamese participant (and the other CLM representatives) as "radical" 236 making them suspicious of the advocates' real motives. Vietnam's representative believed that the activist members wanted to take the lead in the area of human rights and democracy and impose their standards on others. It should be recalled that at the eighth HLTF meeting, the Philippines Foreign Minister had rejected the proposed enabling provision by the HLTF and offered his own proposal with the suggestion that those ASEAN members who felt prepared could join first. This proposal was seen by the CLMV group as an attempt to set (new) rules for the old game. Therefore, the main concern for the Vietnamese participant was the possibility that radical ASEAN members might manipulate the process of creating the human rights body:

In order to implement our Minister's instruction at the AMM Retreat in Siem Riep on the need to clarify what the proposed human rights body is going to do before deciding whether or not to create it and the instruction from the Prime Minister given in the Government Office Document No.2618 on Vietnam's participation in the Project on Assistance for the establishment of an ASEAN Human Rights body dated May 18, 2007 our delegation has actively worked with those from Laos, Cambodia, and Myanmar as well as those from Singapore and Brunei who to some extent

\footnotetext{
${ }^{235}$ MOFA ASEAN Department Report "On the Result of the seventh Meeting of the High Level Task Force on the Drafting of the ASEAN Charter," July 2007, pp. 3-4.

${ }^{236}$ Interview by author in Hanoi, January 10, 2012.
} 
shared our views in navigating the negotiation process in a positive manner to ensure that (if and once the human rights body is created) its principles and operation would be in our interests, thus preventing Indonesia, Malaysia, the Philippines and Thailand from having a radical approach on the issue and manipulating the process. ${ }^{237}$

Myanmar's participant Aung Bwa shared the same concern when he observed that "some of our colleagues were assuming the role of champions of human rights and adopting a 'holier-than-the-Pope' approach."238 Vietnam's HLTF member was also concerned about the possibility of interfering in the internal affairs if the HRB had a monitoring function. At the $10^{\text {th }}$ HLTF meeting, the Vietnamese representative stressed that the body created could only have consultative status. He also preferred to put it in the category of "other organs" in ASEAN's structure. Internal documents show that, in preparation for the subsequent deliberations, Vietnam's HLTF group had summed up the situation of discussion at the eighth meeting and recommended Vietnam's position on the function and location of the HRB as follows:

Indonesia, Malaysia, the Philippines, and Thailand preferred the human rights body to be one of ASEAN principal organs and the item on the TOR to be deleted. Meanwhile, Vietnam, Laos, and Myanmar consisted that the human rights body could only have a consultative status and that TOR must be a basis for the creation of the human rights body in the future. Brunei and Singapore seized the middle ground. Singapore - acting as the new Chair of the HLTF and with a view to pushing forward the ASEAN Charter drafting process so that the Document could be approved as scheduled at the $13^{\text {th }}$ ASEAN Summit in Singapore - suggested ASEAN's organizational structure should not be divided into principal and other organs. Instead, they should be put under the category of 'ASEAN's organ.'

\footnotetext{
${ }^{237}$ MOFA ASEAN Department Report "On the Result of the seventh Meeting of the High Level Task Force on the Drafting of the ASEAN Charter," July 2007, p. 3.

${ }^{238}$ Aung Bwa, "The Jewel in My Crown," in The Making of the ASEAN Charter, eds. Tommy Koh, Rosario G. Manalo and Walter Woon (Singapore; Hackensack, NJ: World Scientific Pub. Co., 2009), 33.
} 
Therefore, in subsequent meeting:

- We should emphasize that in the Chapter 4 on ASEAN's organizational structure there should be a clear distinction between policy-making organs and policy implementation organs and between assisting organs and consultative organs. We do not support Singapore's proposal (because this is one way to blur the location of the human rights body later when it is created.)

- The human rights body, if it is to be created, can only have consultative function. Therefore, it should not be put under category of ASEAN's principal organs. In addition, ASEAN Ministers have not touched upon the issue. $^{239}$

However, as the chronology shows, the Ministers at their third meeting did not touch upon the function of the HRB. They only decided on its location (in Chapter 4 of the Charter). Right up until this meeting, Vietnam's HLTF member continued to raise his opposition to this arrangement. ${ }^{240}$ Further, while admitting that old ASEAN members had made great progress in the areas of human rights and democracy, most notably the creation of national human rights commissions in Indonesia, the Philippines, Thailand and Malaysia, to the Vietnamese these ASEAN members still faced a lot of their own human rights issues. Therefore, they were not in a position to teach others on how to protect and promote human rights. ${ }^{241}$ Differences in approaching the creation of the HRB caused suspicion among the Vietnamese about the real intentions of those supporting it. This suspicion forced the Vietnamese representative to engage in the deliberations so as to prevent the activists from manipulating the process and potentially controlling the operation of the HRB when it was created. And as the chronology shows, Vietnam did not agree with the creation of the HRB until the second meeting of the ASEAN Foreign Ministers on July 30, 2007.

\footnotetext{
${ }^{239}$ MOFA ASEAN Department Memo, "Recommendations on Our Positions in Dealing with the Issue of the Establishment of ASEAN Human Rights Body in the ASEAN Charter in the Preparation for the ninth HLTF Meeting on the Drafting of the ASEAN Charter," August 2007, pp. 1-2.

${ }^{240}$ ASEAN Secretariat, "Record of the $12^{\text {th }}$ Meeting of the High Level Task Force on the Drafting of the ASEAN Charter," October 3-5, 2007.

${ }^{241}$ Interview by author in Hanoi, January 10, 2012.
} 
In short, internal documents show that throughout the negotiations, Vietnam was primarily concerned with what it thought were the intentions, rather than arguments, of those advocating for the HRB. This concern was caused by the ingrained attitude toward human rights - the assumption that the human rights issue was a pretext used by outsiders to intervene in Vietnam's internal affairs. In addition, different approaches to human rights further deepened this concern: the Vietnamese HLTF member saw the effort by activist members to push for an immediate creation of the HRB as a radical move, putting more pressure on those with reservations. As a result, the Vietnamese representative did not trust the intentions of activist members. He did not yield to HRB proponents, stressing that Vietnam could only go along with it if it was a consultative body. Therefore, it was clear enough that the Vietnamese were not persuaded by advocates to go along with the HRB.

\section{Social influence as an explanation}

An alternative account drawing on socialization theory is that social influence was at work in this case. Did concerns about image and "not rocking the boat" lead to a cooperative attitude on the part of the Vietnamese toward the creation of the HRB? The working environment of the drafting process of the ASEAN Charter appears to be more conducive to social influence and there seem to be several reasons in favour of a social influence explanation. For instance, a Vietnamese senior diplomat admitted in an interview that Vietnam's national interest in ASEAN, especially in the context of ASEAN Community building, was to "maintain its credibility and status" and that the creation of the HRB should also be examined in this context. ${ }^{242}$ The decision to go along with the HRB would contribute to realizing that social goal. One member in the Vietnamese HLTF group also admitted in an interview that "they were sensitive to how their actions

\footnotetext{
${ }^{242}$ Interview by the author in Hanoi, January 4, 2012.
} 
were perceived and did not want to be seen as blocking the negotiations." Internal documents also reveal that the Vietnamese did not want to create negative impressions among activist members that they avoided dealing with the issue:

The idea of a regional human rights mechanism was adopted very early at the $26^{\text {th }}$ AMM in Singapore and restated in annual AMM Joint Communiqués. Since then, the Working Group on the Regional Human Rights Mechanism - which was composed of four national human rights mechanisms from Indonesia, Malaysia, the Philippines and Thailand and a number of regional NGOs - has actively lobbied for the creation of this human rights mechanism. Since joining ASEAN, we have tried to delay the materialization of the idea. However, at present some ASEAN members repeatedly urged for the creation of such a human rights mechanism to prevent external forces - taking the advantage of lacking a human rights mechanism in the region - from imposing pressure on and intervening in ASEAN internal affairs. Therefore, it is now time for us not to avoid the issue. Instead, we should participate directly and actively in the process of creating such body in order to set the 'rules of the game,' not creating the impressions that we avoid dealing with regional human rights issue. ${ }^{244}$

The message clearly shows that in addition to the material goal of setting the operational rules for the future HRB that would be in its national interests, Vietnam also had a social goal - seeking to avoid criticism from active participants, thus creating a good image in the eyes of other members. In a research project done by Vietnam's Diplomatic Academy on the establishment of the ASEAN HRB and Vietnam's policy, this social objective was further elaborated:

- Participation in the establishment of the ASEAN Human Rights Body is a manifestation of Vietnam's integration into the common trends of the world and the region on human rights issue. Other members of the world community would highly appreciate our proactive posture in the protection of human rights. This would be beneficiary to Vietnam's external relations and helps boost our status in the international arena.

\footnotetext{
${ }^{243}$ Interview by the author in Hanoi, January 10, 2012.

${ }^{244}$ MOFA ASEAN Department Report "On the Results of the seventh Meeting of the High Level Task Force on the Drafting of the ASEAN Charter," July 2007, pp. 2-3 (emphasis added).
} 
- Participation in the establishment of the ASEAN Human Rights Body significantly contributes to improving our image in the area of human rights protection and thus rejecting fabrications and false allegations of our human rights records.

- Participation in the ASEAN Human Rights Body is also an expression of the Vietnam's spirit of cooperation and solidarity, striving for the Organization's interests. ${ }^{245}$

In addition to the desire to appear as a responsible and proactive member of ASEAN, the possibility of being in a minority group might have also led to change in attitude of the Vietnamese. More specifically, change by the formerly like-minded participants from Lao, Myanmar and Cambodia toward a more cooperative stance might have led to similar change on the part of the Vietnamese participant. During the negotiations Cambodia's HLTF member appeared to be a little bit independent of others in the group. ${ }^{246}$ Indeed, at the eighth HLTF meeting, Kao said:

"This human rights body has to be established as part of the evolutionary process... We agreed that there would be a process. The question is speed where we may not share the same view. Some countries have already had national human rights body. In the case of Cambodia, we are in the process of setting up one. We are not against at all. We respect the process to be done to take care of all concerns of other countries. We can go either way." 247

Kao's reflection after the ASEAN Charter was completed on the implications of a two-tier ASEAN helps us understand his position (and that of the Cambodian government that he represented) during the HRB negotiations. Kao argued that it

\footnotetext{
${ }^{245}$ The Diplomatic Academy of Vietnam Research Project "On the Establishment of the ASEAN Human Rights Body and Vietnam's Policy," (2008), 80.

${ }^{246}$ In the author's interview with one of the Vietnamese HLTF member, the confidence and independence of the Cambodia HLTF member was primarily because of his background.

${ }^{247}$ The ASEAN Secretariat, "Record of the eighth Meeting of the High Level Task Force on the Drafting of the ASEAN Charter," July 22-31, 2007, pp. 134-35.
} 
was time for ASEAN to overcome "the old thinking of dividing ASEAN into old and new members" since this old thinking would not "serve ASEAN well" and that "it could only undermine ASEAN unity." 248 He further stressed that "there is the need to distinguish between domestic political pressures and a new layer of regional responsibilities, and thereby a plan to reconcile these two conflicting sets of demands for the benefit of all. This requires acumen in the international arena, rather than simply a reflexive bowing to internal populist, reactionary forces." 249 With particular reference to human rights as the only issue that divided ASEAN into two groups, Kao's emphasis on ASEAN's unity and the benefit for all reflected his (government's) support for collective interests when ASEAN entered a deeper level of regional integration.

Although Cambodia's progress on human rights and democracy remains modest, the fact that it permitted the establishment of domestic non-government organizations on human rights represents the great strides it has taken in comparison to the situation in Vietnam and Laos. Cambodia has also been in the process of establishing a national human rights institution. ${ }^{250}$ Its representative therefore might have been more comfortable discussing human rights issue than others in the reluctant camp.

The relative independence of Cambodia was also confirmed by internal Vietnamese MOFA documents, which show that Myanmar and Laos were the main partners that Vietnam relied on for a coordinated position in the HRB deliberations. For example, in preparation for the ninth meeting, particularly on two issues of the location of the HRB and the draft of the TOR, Vietnamese HLTF members recommended that:

\footnotetext{
${ }^{248}$ Kao, “A Personal Reflection,” 153-54.

${ }^{249}$ Ibid., 154.

250 "Cambodia set out path to the National Human Rights Institution," Asia Pacific Forum, accessed May 10, 2012, http://www.asiapacificforum.net/news/cambodia-sets-out-path-toestablish-nhri.html.
} 
On the location of the human rights body in Chapter 4, we will actively cooperate with Laos and Myanmar in negotiation in order to put this body in the category of 'Other Organs,' may be after the existing bodies because it is not yet created. ${ }^{251}$

And on the draft of the TOR, Vietnam's position was recommended as follows:

We should emphasize that at the $40^{\text {th }}$ AMM ASEAN Foreign Ministers instructed the HLTF to improve the TOR. Therefore, the HLTF should push forward the completion of the Document so as to submit to the Ministers for consideration. At the same time, we should work with Laos and Myanmar in emphasizing that TOR must be the basis and prerequisite for the future formation of the human rights body. ${ }^{252}$

Thus, it is clear that among the CLMV group, Cambodia appeared more supportive of the HRB. It was revealed that at the seventh HLTF meeting, participants from Laos, Cambodia and Myanmar also came to agree with the proposed HRB, at least in principle. A report on the result of the seventh meeting by the Vietnamese HLTF members confirmed this point when it stated that the issue of whether or not to create the human rights body was no longer a major controversy and that "even participants from Laos, Cambodia, and Myanmar, initially strongly opposed the idea, now became more proactive in discussing the substance of the TOR though they still needed to ask for instruction from home before officially approving it." 253

However, the critical moment came at the second meeting of the ASEAN Foreign Ministers when Vietnam's Deputy Foreign Minister Le Cong Phung

\footnotetext{
${ }^{251}$ MOFA ASEAN Department Memo entitled "Recommendations on Our Positions in Dealing with the Issue of the Establishment of ASEAN Human Rights Body in ASEAN Charter in the Preparation for the ninth HLTF Meeting on the Drafting of the ASEAN Charter," August 2007, p. 2.

${ }^{252}$ Ibid.

${ }^{253}$ MOFA ASEAN Department Report "On the Results of the seventh Meeting of the High Level Task Force on the Drafting of the ASEAN Charter," July 2007, p. 3.
} 
finally announced Vietnam's decision to go along with the initiative, subject to the TOR and the consultative status of the HRB. As ASEAN Secretary-General Ong Keng Yong observed, at the meeting only two or three Foreign Ministers said they would refer to it (the HRB) after the TOR were agreed. ${ }^{254}$ That meant a clear majority of the ASEAN Foreign Ministers agreed with the initiative and Vietnam was left in a minority. Phung's announcement, according to Ong, helped put an end to the debate whether or not to create a HRB for ASEAN. ${ }^{255}$ In an interview, one member of the Vietnamese HLTF group conceded that even Laos and Myanmar agreed with it before Vietnam. ${ }^{256}$

Change on the part of other in-group members was reconfirmed at a meeting in Hanoi right after the eighth HLTF meeting. The meeting brought together Vietnamese officials from relevant departments to discuss the HRB. The Vietnamese HLTF member chaired the meeting. He reported on the progress of the ASEAN Charter drafting process and stressed that the objective of the meeting was to discuss how Vietnam should go along with the proposed HRB when the majority of ASEAN members supported it, including Cambodia and Laos. The meeting did not focus on whether or not Vietnam would agree with it, rather, participants were required to make policy recommendations on the possible form and function of and specific issues and tasks taken by the body when it was created. $^{257}$

In short, it can be concluded that Vietnam came to agree with the HRB because it did not want to be isolated when a majority of ASEAN members finally came to agree with the initiative. Social influence, which emphasizes image

\footnotetext{
${ }^{254}$ The ASEAN Secretariat, "Record of the $10^{\text {th }}$ High Level Task Force Meeting on the Drafting of the ASEAN Charter."

${ }^{255}$ Ibid.

${ }^{256}$ Interview by author in Hanoi, April 8, 2013.

${ }^{257}$ The author attended this meeting.
} 
concerns and "not rocking the boat" therefore provides a more plausible explanation for Vietnam's cooperative attitude toward the creation of the HRB.

\section{Conclusion}

The above analysis shows that during the drafting of the ASEAN Charter, activist members did not successfully persuade the Vietnamese representative to go along with their plan. Rather, the Vietnamese participant remained suspicious of their intentions. The push for the immediate creation of the HRB was seen as a radical move and the Vietnamese feared that the body could be manipulated by activist ASEAN members. As a result, the Vietnamese representative actively participated in the negotiation from the outset so as to control the process in a way that if the body were to be created, its operation would not be hostile to Vietnamese interests.

Social influence provides a more plausible explanation for Vietnam's decision to go along with the initiative. On the one hand, image concerns prevented the Vietnamese representative from avoiding human rights issue altogether, especially when there was a shared understanding among ASEAN members on human rights protection and promotion as a goal. On the other hand, being left in the minority eventually forced the Vietnamese to change their attitude toward supporting the creation of the HRB.

Vietnam's endorsement of the HRB, however, reflected a change in preference. Initially, Vietnam preferred continued consultations on human rights, rather than establishing a regional mechanism on the issue. And the decision was made in an environment where threats and material side payments were not present. Internal documents on the drafting process of the ASEAN Charter do not show any evidence that the activist members, individually or collectively, offered material rewards in exchange for support from the more reluctant states. Their 
pressure throughout the negotiations did not constitute a threat, either. Although activist members appeared "radical" in pushing the initiative forward, the Vietnamese representative did not feel threatened in not moving from his initial position. Rather, as the chronology shows, he did not yield to arguments by activist members. And the decision to go along with the HRB, when it came, came from a higher-ranking official.

There is also no evidence that outside intervention helped elicit Vietnam's cooperative behaviour towards the creation of the HRB. Although human rights issues have long been an obstacle in bilateral relationships between individual ASEAN members - and the Association as a whole - and the West, records of the HLTF meetings do not show any efforts by Western governments to intervene in the work of the Task Force so as to facilitate progress on the HRB. Concerns were raised in the West following Myanmar's crackdown on protesters in August and September $2007 .^{258}$ However, the debate on whether to establish a HRB was settled in July, before protests broke out in Myanmar. Thus the possibility that the West took advantage of Myanmar's human rights situation to put pressure on ASEAN to create a regional human rights mechanism can be ruled out.

${ }^{258}$ See for example, Donald K. Emmerson, “ASEAN's 'Black Swans',” Journal of Democracy 19, no. 3 (2008):70-84. 


\section{CHAPTER V}

\section{THE ASEAN REGIONAL FORUM AND PREVENTIVE DIPLOMACY}

This chapter explores if Vietnam has endorsed the Preventive Diplomacy papers and hence accepted the norm of preventive diplomacy as a result of socialization in the ASEAN Regional Forum (ARF). It is in two parts. The first section provides background on the ARF's debates about PD, focusing on deliberations between two broad groups of states in the period 1997-2001. Vietnam was part of a reluctant group that also included China, Russia, India and almost all ASEAN members. Meanwhile, a group of activist members including Japan, the United States, Australia and Singapore pressed for the acceptance of PD. Deliberations eventually led to the adoption of three documents in 2001, namely the Paper on Concepts and Principles of Preventive Diplomacy (PD paper), the Terms of Reference for the ARF Experts/Eminent Persons Register and the Paper on the Enhanced Role of the ARF Chair (hereinafter PD papers collectively). ${ }^{259}$

The second section explores three possible explanations - mimicking, social influence and persuasion - for Vietnam's endorsement of the PD papers. First, socialization suggests that Vietnam's decision to go along with PD was an act of mimicking: that as a novice in the ARF, Vietnamese officials simply believed that they should act like others and endorse the PD documents. The decision was taken without Vietnam coming to accept the benefits of PD. Second, a social influence explanation would argue Vietnam came to agree with the PD papers because of image concerns and a desire to "not rock the boat." In other

259 "Chairman's Statement of the Eighth Meeting of the ASEAN Regional Forum," ASEAN, July 25, 2001, http://aseanregionalforum.asean.org/library/arf-chairmans-statements-and-reports.html. 
words, Vietnamese officials found themselves in a minority when other likeminded participants changed their attitude to be more supportive of PD documents and realized that they would be seen as blocking the ARF process if they did not follow the majority to endorse the adoption of these documents. A third explanation is that persuasion was at work and Vietnamese officials finally came to judge the arguments advanced by advocates as convincing: by taking up PD the ARF would remain relevant and more capable of responding to regional security issues. Put differently, taking up PD was in the collective interests rather than against the national interests of participating countries.

By tracing internal debates on PD, the thesis argues that Vietnam's action was not strictly an act of mimicking in order to stay safe when the ARF was in an uncertain transition period. Rather, state representatives saw a potential threat if they took up PD: moving the ARF towards the second stage and employing PD measures might give activists an opportunity to interfere in Vietnam's internal affairs. As a result, a course of action was carefully charted out whereby Vietnamese officials allied with the reluctant camp to counter PD advocates. Similarly, there is little evidence that persuasion occurred. Vietnamese officials did not trust the PD advocates and were suspicious of their attempts to push PD forward. Therefore, they sought to slow down PD discussions and delay the adoption of PD papers.

Social influence appears to be the most plausible explanation. Vietnamese officials found that they were in a minority when the Chinese - who they had seen as a behaviour exemplar - suddenly changed their attitude to become more receptive to $\mathrm{PD}$. Given the limited role of the ARF Chair in setting the agenda, Vietnam had little choice but to accommodate the major powers' preferences to incorporate the adoption of PD papers into the $8^{\text {th }}$ ARF agenda in 2001. However, attitudinal change on the part of the Vietnamese did not necessarily mean a change in preference. In PD deliberations from 2001 onward Vietnamese officials 
still sought to prevent the ARF from entering the PD stage and institutionalizing it. They did not even take advantage of holding the ARF Chair in 2010 to push forward the PD agenda at least to show a more positive attitude when there was urgent call for the ARF to embark on the second stage of development by implementing some specific PD measures. On the contrary, Vietnam remains reluctant, especially when it comes to intra-state PD measures.

\section{PD deliberations and Vietnam's participation: A chronology}

Debates about PD at Track I started in 1997. According to Yuzawa, at the $4^{\text {th }}$ ARF Senior Officials Meeting (SOM), Japanese officials proposed establishing an inter-sessional working group on PD. ${ }^{260}$ The proposal was supported by the United States, Canada, Australia and Singapore, but was sharply criticized by China. ${ }^{261}$ The Chinese argued that "the definitions of PD were still too diverse and it was therefore too early to launch a discussion at the Track I level." ${ }^{262}$ Fear of interference in its domestic affairs was often cited as the main reason for Beijing's opposition to any such initiative. ${ }^{263}$ As the Chair of the $4^{\text {th }}$ ARF, Malaysia suggested a compromise to overcome the split between the two groups by putting PD on the agenda of the Inter-Sessional Group meeting on Confidence Building Measures (ISG-CBM) so the two issues could be discussed in tandem. This consensus was then reflected in the Chairman's Statement of the $4^{\text {th }}$ ARF. ${ }^{264}$

260 Takeshi Yuzawa, Japan and the ASEAN Regional Forum: From Enthusiasm to Disappointment," in Cooperative Security in the Asia-Pacific: The ASEAN Regional Forum, eds. Jürgen Haacke and Noel M. Morada (London; New York: Routledge, 2010), 97.

261 Ibid.

262 Takeshi Yuzawa, "The Evolution of Preventive Diplomacy in the ASEAN Regional Forum: Problems and Prospects," Asian Survey 46, no. 5 (2006): 792.

${ }^{263}$ See for example, Christopher R. Hughes, "China Membership of the ARF and the Emergence of an East Asian Diplomatic and Security Culture," in Cooperative Security in the Asia-Pacific: The ASEAN Regional Forum, eds. Jürgen Haacke and Noel M. Morada (London; New York: Routledge, 2010), 54-71.

${ }^{264}$ Paragraph 13 of this statement read, "The Ministers held a useful exchange of views on the future direction of the ARF process and in this connection, on the relationship between confidence building and preventive diplomacy. It recalled that the 2nd ARF had agreed that where subject matters at Stage I and Stage II overlap, such matters can proceed in tandem with Stage I. The 
As mandated in the $4^{\text {th }}$ ARF Chairman's Statement, the two subsequent ISG-CBM meetings held in November 1997 in Brunei and in March 1998 in Australia discussed areas of overlap between CBMs and PD. Four specific areas of overlap were identified, including (i) an enhanced role for the ARF Chair, particularly the idea of a good offices role; (ii) the development of a register of Experts and Eminent Persons among ARF participants; (iii) an annual Security Outlook (ASO); and (iv) voluntary background briefing on regional security issues. $^{265}$ While some participants suggested the possibility of considering common approaches and understandings on preventive diplomacy, the summary reports still stressed the importance of proceeding in an "incremental and step-bystep manner and of taking decisions by consensus while taking into consideration the interests and comfort level of all ARF participants." 266 This way of approaching PD clearly reflected the preference of the reluctant members who found themselves unprepared to take on PD. Meanwhile, activist members such as the US felt frustrated. ${ }^{267}$ The then US Secretary of State Madeleine Albright stated that: "We should take the next steps in this process by investigating the overlap between CBMs and PD. While the confidence building foundations must be solid, the ARF must also move forward if it is to remain vital and relevant because the traditional security challenges the ARF was established to address must be met.",268

\footnotetext{
Ministers agreed to request the ISG on CBMs to identify such matters and ways and means of addressing them while maintaining the focus on CBMs."

265 "Co-Chairmen's Summary Report of the Meetings of the ARF Inter-Sessional Support Group on Confidence Building Measures," ASEAN Regional Forum, November 4-6, 1997 and March 46, 1998, http://www.asean.org/archive/arf/5ARF/ISG-CBM-BSB-Sydney/Report.pdf.

${ }^{266}$ Ibid.

${ }^{267}$ See Brad Glosserman, "The United States and the ASEAN Regional Forum: A Delicate Balancing Act," in Cooperative Security in the Asia-Pacific: The ASEAN Regional Forum, eds. Jürgen Haacke and Noel M. Morada (London; New York: Routledge, 2010), 36-53.

${ }^{268}$ Quoted in Yuzawa, "The Evolution of Preventive Diplomacy in the ASEAN Regional Forum: Problems and Prospects," 793.
} 
At the $6^{\text {th }}$ ARF in July 1999, there was a consensus among participants on the continued implementation of CBMs and at the same time to start discussion on the concept and principles of PD and four areas of overlap between CBMs and PD. Substantial discussions on PD were then conducted in 2000-2001. The process started with Singapore's offer on behalf of ASEAN to prepare a draft paper on the concept and principles of PD. At the second ISG-CBM held in April 2000 in Singapore, Japan, acting as a co-chair, presented its paper on an enhanced role for the Chair. Then, the $7^{\text {th }}$ ARF held in July 2000 in Thailand reached an agreement that the ARF Chair would be the contact person for the Register of the use of the EEPs. South Korea drafted this paper as a basis for discussions on the procedures, scope and financial principles.

Subsequent PD deliberations focused on these three papers. Vietnamese officials were most concerned with the first two: the concept and principles of PD and the enhanced role of the Chair. They believed that the adoption of these papers would mark a turning point for the ARF to officially enter its second stage of development - a trend they felt they had to prevent. ${ }^{269}$ Meanwhile, the paper on the Register of the EEPs only involved technical issues such as modalities, scope, procedures and financial issues. Thus, they were less concerned with this paper.

\section{PD deliberations in inter-sessional year 1999-2000}

The state of the ARF's evolution and of the PD discussions in 1999-2000 was summed up by the Vietnamese officials as follows:

ARF's activities have been increased both in intensity and scope. The institution is entering a complicated transition period marked by possible changes in substance of cooperation and institutional building: substantial and more binding CBMs are being implemented and the forum is to move to the next stage of preventive diplomacy. The United States, Japan and other Western participating countries want to institutionalize the ARF and move it forwards the PD stage. Meanwhile, China, India, and Russia are

${ }^{269}$ MOFA ASEAN Department Documents “On chairing the $8^{\text {th }}$ ARF, July 25, 2001,” p. 5. 
reluctant. Regarding PD stage, ASEAN is split into two groups with Thailand, Singapore, the Philippines and Brunei on the activist side and the remaining on the reluctant side. However, ASEAN members have the same concern on the possibility of the ARF to be institutionalized, given the fear of losing their role as the driving force. The challenge for ASEAN now is how to properly deal with these two issues so as to maintain its central role in the ARF and for the forum to develop and remain relevant. At present, CBMs are being implemented in conjunction with the discussions on PD definition and concepts as well as the four measures in overlap, including an enhanced role for the ARF Chair, particularly the idea of a good offices role, the development of a register of Experts or Eminent Persons, annual Security Outlook, and voluntary background briefing on regional security issues. ${ }^{270}$

Against this background, Vietnam found itself unprepared and remained cautious of attempts by activists to move the ARF forward. Although it did not oppose discussion of the substance of the PD papers, in the Vietnamese perspective CBMs should continue to be the foundation and the main thrust of the ARF process and that fundamental principles of the institution must be upheld. In other words, Vietnam's preference was not to move the ARF to the second stage of preventive diplomacy which its officials saw as having possible negative implications for the country's security and development. ${ }^{271}$

\section{On Concept and Principles of PD}

In October 1999 ASEAN approved Singapore's Draft Paper and the document was introduced at the first ISG-CBM meeting in inter-sessional year 1999-2000 held in Tokyo in 13-14 November, 1999. The definition of PD offered in this draft paper was based on the proposed definition worked out by a

\footnotetext{
${ }^{270}$ MOFA ASEAN Department Background Documents "On the ARF" prepared for the $7^{\text {th }}$ ARF, July 2000.

${ }^{271}$ Ibid.
} 
Workshop organized by the Council for Security Cooperation in the Asia-Pacific (CSCAP) in $1999 .{ }^{272}$ It read:

Preventive diplomacy is consensual diplomatic and political action with the aim of:

- Preventing severe disputes and conflicts from arising between States which pose a serious threat to regional peace and stability;

- Preventing such disputes and conflicts from escalating into armed confrontation; and

- Preventing such disputes and conflicts from spreading geographically. ${ }^{273}$

The co-chairs' summary report said that participants at the first ISG-CBM in inter-sessional year 1999-2000 in Tokyo had exchanged preliminary views on the concept and principles of PD and fuller discussion was expected to be carried out at the second ISG-CBM in Singapore. ${ }^{274}$ In preparation for the second ISG-CBM, participants were requested to submit their written comments to Singapore by February 1, 2000. The first round of the debate on Singapore's paper was primarily with ARF's non-ASEAN members. The United States, Canada, Australia, Japan and Singapore agreed with all three objectives mentioned above. They also stressed the importance of the third objective - preventing disputes and

${ }^{272}$ For the role of Track Two in PD deliberations, see Pacific Forum CSIS, "Preventive Diplomacy: Charting a Course for the ASEAN Regional Forum," Issues \& Insights no.3-02 (2002): 1-11; Mely Caballero-Anthony, Regional Security in Southeast Asia: Beyond the ASEAN Way (Singapore: Institute of Southeast Asian Studies, 2005), 134-43; Brad Glosserman, "The United States and the ASEAN Regional Forum: A Delicate Balancing Act," in Cooperative Security in the Asia-Pacific: The ASEAN Regional Forum, eds. Jürgen Haacke and Noel M. Morada, (London; New York: Routledge, 2010), 36-53.

${ }^{273}$ Quoted in Acharya, Constructing a Security Community in Southeast Asia, 202-3. Compared to the proposed definition worked out by the CSCAP workshop, the third objective of PD in Singapore's draft paper was revised and shortened. The original third objective proposed by the CSCAP workshop was "Limiting the intensity of violence and humanitarian problems resulting from such conflicts and preventing them from spreading geographically."

274 "Co-Chairmen's Summary Report of the Meetings of the ARF Inter-sessional Support Group on Confidence Building Measures," ASEAN Regional Forum, November 13-14, 1999 and April 5-6, 2000, http://www.aseanregionalforum.org/PublicLibrary/ARFChairmansStatementsandReports/CoChair mensSummaryReportoftheMeetingsofth/tabid/116/Default.aspx. 
conflicts from spreading geographically - when it came to humanitarian issues. ${ }^{275}$ Meanwhile, on February 1, 2000 China offered an amended definition of PD. China defined PD as "peaceful diplomatic actions undertaken by sovereign states to prevent armed conflicts between states in the region with the consent of all states directly involved in a dispute. ${ }^{276}$ It also proposed to delete the first and the third objectives in Singapore's paper. Acharya described the negotiations between China and Singapore as follows:

China had also recommended the deletion of "preventing such disputes and conflicts from spreading geographically' from the original ASEAN definition, on the ground that this belonged to the third stage of the ARF, known as 'elaboration of approaches to conflicts', and hence was premature at the PD stage. The Singapore Concept Paper rephrased it: "to help minimize the impact of such disputes and conflicts on a region'. Another of China's proposed amendments was to delete the phrase: 'preventing severe disputes and conflicts from arising between States which pose a serious threat to regional peace and stability', altogether, because as the Chinese put it, 'conflicts usually refer to armed actions, hence are not at the same level with disputes would render the ARF's mandate too 'ambitious'. But the Singapore-drafted Concept Paper kept the reference to 'dispute. ${ }^{277}$

Singapore then revised the draft paper based primarily on the comments by non-ASEAN members. In the end, the Concept Paper on PD dated 5 April 2000 drafted and circulated by Singapore at the second ISG-CBM, 5-6 April 2000, accepted the language proposed by Beijing as follows:

"PD is consensual diplomatic and political action taken by sovereign states with the consent of all directly involved parties;

To help prevent disputes and conflicts from arising between States that could potentially pose a threat to regional peace and stability;

\footnotetext{
${ }^{275}$ MOFA ASEAN Department Background Documents "On the ARF" in preparation for the $7^{\text {th }}$ ARF, July 2000.

${ }^{276}$ Ibid.

${ }^{277}$ Quoted in Acharya, Constructing a Security Community in Southeast Asia, 202-3.
} 
To help prevent such disputes and conflicts from escalating into armed confrontation;

To help minimize the impact of such disputes and conflicts on the region., 278

Vietnam fully developed its position on PD in preparation for the $7^{\text {th }}$ ARF in July 2000. On Singapore's paper, its representatives suggested the paper should be revised to restate that the "ARF is a forum for political and security dialogue and cooperation with a view to enhancing peace and stability in the region and that confidence building measure is the foundation and main thrust of the whole ARF." 279 Specifically, on the definition of PD, Vietnam was of the following views:

PD is a way to pursue the motto "better prevention than cure." Therefore, PD should apply only to pre-crisis conflicts between states, having the effect of early warning for early prevention. It is not supposed to apply in a circumstance where armed conflict already happened. If it fails to detect and prevent the problems from escalating into armed conflicts then we need approaches to conflict resolution, which falls into the third stage of the ARF process.

We can go along with the first two objectives. With regard to the third objective, the idea of "minimize the impacts of such disputes and conflicts on the region" is rather vague, and may lead to different interpretation. Therefore, we would like to see the formulation of the third objective be modified or deleted. ${ }^{280}$

On PD as a concept, Vietnamese officials proposed to delete the whole section on the Role of the Chair as a PD measure whereby the ARF Chair could play a role as determined by ARF members. ${ }^{281}$ They saw the inclusion of the role of the ARF Chair as a PD measure problematic at this stage, arguing that the ARF

\footnotetext{
${ }^{278}$ MOFA ASEAN Department "PD paper circulated at Singapore ISG-CBM, April 5-7, 2001."

279 MOFA ASEAN Department Memo “On Vietnam's Views on Singapore discussion paper (Paper circulated at Singapore ISG-CBM April 5-7, 2000).”

280 MOFA ASEAN Department Talking points for the $7^{\text {th }}$ ARF "On Paper on the Concept and Principles of PD of Singapore," p.1.

281 MOFA ASEAN Department Memo “On Vietnam's Views on Singapore discussion paper (Paper circulated at Singapore ISG-CBM April 5-7, 2000).”
} 
was still in the process of considering the issue of enhancing the role of the ARF Chair. In other words, for them "it was premature to include the role of the ARF Chair as a PD measure." 282 On PD principles, while agreeing with all proposed principles, Vietnamese participants proposed reordering these principles so as to reflect first and foremost the importance of universally recognized basic principles of international law and inter-state relations. ${ }^{283}$

\section{On measures of overlap between CBMs and PD}

At the second ISG-CBM held in Singapore in April 2000, the Japanese cochair presented its paper on the enhanced role of the Chair which included the following specific recommendations:

- Providing early warning by drawing attention to potential regional disputes and conflicts that might hurt regional stability.

- Convening emergency meetings

- Issuing statements at the chair's discretion (without consent of ARF members)

- Facilitating discussion on the building of norms in the ARF

- Enhancing liaison with external parties such as international organizations and Track Two forums.

- Promoting confidence building among ARF members by facilitating information exchange and dialogue.

- Facilitating discussion among ARF members on potential areas of cooperation. ${ }^{284}$

Activists strongly supported giving the Chair responsibilities to call for special sessions or to issue a Chairman's statement as situations warrant. Vietnamese participants argued that it was premature to discuss about that and such a role for the Chair "was not suitable for ARF process in the foreseeable

\footnotetext{
${ }^{282}$ MOFA ASEAN Department Talking points for the $7^{\text {th }}$ ARF "On Paper on the Concept and Principles of PD of Singapore," p.2.

${ }^{283}$ MOFA ASEAN Department Memo "On Vietnam's Views on Singapore discussion paper (Paper circulated at Singapore ISG-CBM April 5-7, 2000)".

${ }^{284}$ Quoted in Takeshi Yuzawa, "The Evolution of Preventive Diplomacy in the ASEAN Regional Forum: Problems and Prospects," 794.
} 
future." 285 Vietnam's position on the enhanced role for the Chair was articulated in MOFA talking points prepared for the $7^{\text {th }}$ ARF as follows: first, regarding the Chair's liaisoning role with external parties, Vietnamese officials were of the view that the Chair could conduct the role on an informal and case-by-case basis with prior consent of the ARF participants for the purpose of exchanging information and sharing experiences and not representing the ARF in any way in other fora. In addition, they supported informal dialogue between the Chair and representatives of Track Two but only on a case-by-case basis for information sharing; second, Vietnamese officials were of the view that the role of the Chair in coordinating between meetings should be limited. They recommended the ARF Chair act as focal point to co-ordinate positions among ARF members, mainly with a view to making annual ARF Chairman's statements and compiling the ASO without editing. They supported the proposal that the ARF Chair could act as a conduit for information sharing among the ARF participants but on a voluntary basis only; third, regarding the role for good offices, Vietnamese officials recommended the following:

- The Chair's role should limit to facilitating contacts, information exchanges and dialogue among parties concerned, facilitating the search for a conciliatory and peaceful solution.

- The Chair should not involve in fact finding mission, negotiating or imposing a solution.

- In order to carry out the job, the Chair should have consent of the ARF participating and all the parties concerned. He should strictly observe the principles of full respect for the independence, sovereignty and noninterference into the internal affairs of other countries.

- It is premature to talk about regular support mechanism for the ARF Chairman because ARF itself does not have its secretariat. ARF should

${ }^{285}$ MOFA ASEAN Department Talking points for the $7^{\text {th }}$ ARF “On Measures of overlap between CBMs and PD," p. 2. 
take primary responsibility. The possibility of using the ARF Troika mechanism might be further considered. ${ }^{286}$

As for the registration of experts or eminent persons, Vietnamese officials took note of the usefulness of the proposal as a "pool of resources" whereby "they could provide non-binding professional advice and recommendations and carry in depth studies upon request by the ARF participants. ${ }^{, 287}$ However, they were concerned with a number of issues such as modalities, scope, procedures and financial implications which needed to be properly addressed before they could go along with it.

\section{PD deliberations in inter-sessional year 2000-2001}

At the first ISG-CBM held in Seoul in November 1-3, 2000 it was reported that participants did not discuss the three Papers, given various divergent views. Instead, it was decided that participants should submit their written comments to Singapore, Japan and Korea for review and the three mediators would then provide some suggestions on areas for future discussion at the second ISG-CBM in Kuala Lumpur in April 2001. ${ }^{288}$ The state of PD discussions before the ISGCBM in Kuala Lumpur was summed up by the Vietnamese participants as follows:

The meeting is being held at a time when the ARF is in a complicated period: the United States, Japan and other Western participating countries argued that the forum is at a standstill, thus calling for moving onto PD stage and institutionalizing the forum. Meanwhile, China is cautious, stressing on confidence building, and unprepared to move onto the PD stage and to institutionalize the forum. ASEAN is on the one hand reluctant to move on PD stage and to institutionalize the forum given the

\footnotetext{
286 Ibid.

287 Ibid.

288 "Co-Chairmen's Summary Report of the Meeting of the ARF Inter-sessional Support Group (ISG) on Confidence Building Measures (CBMs)," ASEAN Regional Forum, accessed June 28, 2012, http://aseanregionalforum.asean.org/library/arf-chairmans-statements-and-reports/162.html.
} 
fear of losing the role of the driving force. On the other hand, it also wants to have some progress so as for the ARF to get out of the current situation. $^{289}$

Indeed, US officials urged ARF participants to take advantage of the current regional situation - regional countries enjoyed good relations with one another and the region was free from interstate conflict - "to develop and equip the ARF with tools needed to respond effectively and in a timely way to emerging crisis. ${ }^{290}$ In particular, they supported proposals on the enhanced role of the Chair and the Register of the EEPs, seeing them as "the most important proposals now being considered to strengthen the ARF." ${ }^{291}$ US officials also argue that progress on these issues which were seen as the operational side of the discussion of the PD Concept and Principles would "enhance significantly the ARF's capability to play a constructive, stabilizing role in the region." ${ }^{292}$ Australian officials had the same view, arguing that it was the time for the ARF to "move beyond theoretical discussion to start work on practical preventive diplomacy mechanisms."293 They called for agreement on the three papers at the ISG-CBM meeting in Kuala Lumpur even if the "agreed areas" of the papers were reduced. ${ }^{294}$ Canadian participants also proposed the ARF to chart its course in PD by beginning to 'test the waters' in those areas of PD with which the group was comfortable. ${ }^{295}$

Chinese diplomats meanwhile repeatedly stated that they did not agree with the first and third objectives in Singapore's paper and proposed their

${ }^{289}$ MOFA ASEAN Department Memo dated April 4, 2001 "On Preparation for the $2^{\text {nd }}$ ISG-CBM, Malaysia, April15-20, 2001."

${ }^{290}$ MOFA ASEAN Department Background Documents “US comments on Singapore's paper and Japan's paper” prepared for the $2^{\text {nd }}$ ISG-CBM, Kuala Lumpur, Malaysia, April15-20, 2001.

291 Ibid.

292 Ibid.

${ }^{293}$ MOFA ASEAN Department Background Documents “Aide Memoire on three papers prepared by Singapore, Japan and Republic of Korea by Australia High Commission Singapore dated January 29, 2001" prepared for the $2^{\text {nd }}$ ISG-CBM, Kuala Lumpur, Malaysia, April15-20, 2001.

294 Ibid.

295 MOFA ASEAN Department Background Documents "Canada's written comments on Singapore's Paper dated January 30, 2001" prepared for the $2^{\text {nd }}$ ISG-CBM, Kuala Lumpur, Malaysia, April15-20, 2001. 
deletion. ${ }^{296}$ Regarding the second objective, China proposed to reword the sentence into "for the purpose of preventing the existing disputes between and among states from developing into armed conflict." ${ }^{, 297}$ China also proposed to include one more principle, asserting that PD "rests upon principle of neutrality, justice and impartiality." ${ }^{298}$ Regarding the enhanced role of the Chair, as Yuzawa observed, prior to the ISG-CBM in Kuala Lumpur Chinese participants continued to oppose substantial discussion on the topic, arguing that it should be discussed later after the ARF had finalized the concept and principles of PD. ${ }^{299}$ Specifically, China did not agree with the proposal for the Chair to convene special sessions, arguing that "the meetings that have been regularized such as the annual ARF ministerial meetings, senior official meetings, and the ISG-CBM provided enough occasions and exchange of views., 300

Vietnam's position on Singapore's paper on Concept and Principles of PD remained unchanged since it was developed for the $7^{\text {th }}$ ARF in July 2000. There were, however, some changes in its position toward Japan's paper on the enhanced role of the Chair, reflecting a more cautious attitude. On principles proposed in the paper, particularly on the enhanced role of the Chair in "good offices" and "coordination" in between ARF meetings, Vietnamese officials proposed that activities under such roles must be taken "on an informal and case by case basis and with prior consultation with and consent of all ARF participants." ${ }^{301}$ In addition, the ARF Chair when performing such roles "must

296 MOFA ASEAN Department Background Documents "China's written comments on Singapore's Paper dated January 9, 2001" prepared for the $2^{\text {nd }}$ ISG-CBM, Kuala Lumpur, Malaysia, April15-20, 2001."

297 Ibid.

298 Ibid.

${ }^{299}$ Yuzawa, “The Evolution of Preventive Diplomacy in the ASEAN Regional Forum," 195-96.

300 MOFA ASEAN Department Background Documents "China's written comments on Singapore's Paper dated January 9, 2001" prepared for the $2^{\text {nd }}$ ISG-CBM, Kuala Lumpur, Malaysia, April 15-20, 2001.

301 MOFA ASEAN Department Document "Vietnam's Views on Japan's discussion paper (revised) 'Enhanced role of the ARF Chair Discussion of the ARF ISG on CBMs." The original passage in Japan's paper was "In accordance with basic principles of international law and established ARF practices, the enhanced roles of ARF's Chair in 'good offices' and 'coordination 
observe basic principles of international law and established ARF practices and principles, particularly the principles of respect for sovereignty and noninterference in the internal affairs of any countries."

Furthermore, Vietnamese officials did not agree for the Chair to convene emergency meetings (or special sessions) and to carry out activities during intervals, fearing that this may lead to the formation of an ARF Troika. ${ }^{303}$ Other proposed revisions included replacing "mechanism" with "modalities" in responding to the suggestion in Japan's paper that "the ARF should discuss an appropriate mechanism to support the ARF Chair so that the Chair can carry out the role in 'good offices' and 'co-ordination in between ARF meetings' smoothly and effectively." 304 Vietnamese officials appeared to be sensitive to phrases that they saw as attempts by activists to form binding mechanisms. They also repeatedly stressed the need to have the consent of all ARF participants for the Chair to carry out the proposed activities. Vietnamese officials stated that they could go along with the proposal that "the ARF Chair could draw on expertise and resources of the ARF members and that of external parties and Track II organizations" if such activity was undertaken informally upon request by the Chair and with consent of ARF participants. ${ }^{305}$

in between ARF meetings' are aimed at enhancing mutual understanding and promoting the continuity and efficiency of the ARF process."

302 Ibid.

${ }^{303}$ MOFA ASEAN Department Report submitted to the Foreign Minister "On some issues relating to the ARF SOM in May 2001 in Hanoi," p. 4.

304 MOFA ASEAN Department Document “On Vietnam's Views on Japan's discussion paper (revised) 'Enhanced role of the ARF Chair Discussion of the ARF ISG on CBMs." The original passage of section 3 in Japan's revised paper on "mechanism to support the ARF Chair" was "The ARF should discuss an appropriate mechanism to support the ARF Chair so that the Chair can carry out the role in 'good offices' and 'coordination in between ARF meetings' smoothly and effectively."

${ }^{305}$ Ibid. The original passage of item b, section 3 in Japan's paper was "The ARF Chair could draw on expertise and resources of the ARF members and that of external parties and Track II organizations." 
There were divergent views among ARF participants prior to the Kuala Lumpur ISG-CBM in April 2001, especially on two issues: the PD definition and the role of the ARF Chair. Singaporean diplomats therefore suggested the ISGCBM in Kuala Lumpur focus on these two issues. ${ }^{306}$ Detailed discussion took place at the meeting. Participants agreed to adopt the PD paper as a snapshot of the state of current discussion on PD in the ARF. ${ }^{307}$ At the same time, they decided that the ISG-CBM would continue to discuss PD and focus on those issues where there remained divergence of views."308 Japan was asked to further revise its paper based on the suggestions of ARF countries. ${ }^{309}$ Therefore, prior to the ARF SOM in May 2001, it seemed unlikely that the three PD papers would be adopted.

However, as it turned out, the three papers were quickly adopted at the $8^{\text {th }}$ ARF in Hanoi, July 2001. Since the ARF SOM is the key mechanism to set up the agenda for the annual ARF meetings, consensus and the decision to adopt the three papers must have been reached at the ARF SOM held in Hanoi in May. The adoption of the three PD documents therefore reflected the temporary consensus among ARF participants. Vietnamese Foreign Minister Nguyen Dy Nien as the Chair of the $8^{\text {th }}$ ARF stated that "the meeting agreed only on the concept of PD and the ARF still emphasized confidence building as the main thrust." 310 This meant PD would be a work in progress and that even the definition and principles were still subject to change. Furthermore, the content of the ARF concept and principles of PD were argued to be further watered down in many aspects. According to Yuzawa, the adoption of the PD papers at the $8^{\text {th }}$ ARF was to show

\footnotetext{
${ }^{306}$ Diplomatic note by Singapore Ministry of Foreign Affairs dated February 24, 2001 sent to the Republic of Korea and Malaysia.

307 "Co-Chairmen's Summary Report of the Meeting of the ARF Inter-sessional Support Group (ISG) on Confidence Building Measures (CBMs), ASEAN Regional Forum, Seoul, November 13, 2000 and Kuala Lumpur, April 18-20, 2001, http://aseanregionalforum.asean.org/library/arfchairmans-statements-and-reports/162.html.

308 Ibid.

${ }^{309}$ Ibid., paragraph 45.

${ }^{310}$ Quoted in Takeshi Yuzawa, Japan's Security Policy and the ASEAN Regional Forum: The Search for Multilateral Security in the Asia-Pacific (London; New York: Routledge, 2007), 101.
} 
that the Forum could make some progress on PD in response to criticism from inside and outside ARF, rather than reflecting a common understanding on PD among participants. $^{311}$

\section{De facto consensus on PD}

The above chronology shows that PD deliberations at Track I were most robust in 2000-2001. There were clearly two camps. A group of activist members included Japan, the US, Australia, Canada and some ASEAN members such as Singapore, Thailand, and the Philippines. Within this group the US, Australia and Japan were the most outspoken. The activist members advanced the argument that, to maintain its relevance, it was the right time for ARF to take up PD. They also proposed many concrete PD measures that were arguably applicable to the Asia-Pacific, where a number of hot spots existed such as the South China Sea dispute. Meanwhile, the more reluctant members were China, Russia, India, Vietnam, and other ASEAN members. They stressed moving ARF at a pace comfortable to all in its evolution from the stage of confidence building measures to the development of PD and insisted on discussion of PD concept and principles before working on concrete PD measures. Singapore and Japan as activist members played a mediating role between the two camps.

Deliberations at Track I finally resulted in the adoption of the three papers on PD in 2001. At the time of their adoption, the PD papers were seen as a reflection on the state of $\mathrm{PD}$ discussions among ARF members rather than a consensus or compromise they had reached. However, given that there have been no substantial deliberations on PD in general in subsequent ISG - CBM meetings since 2001 what was agreed in the PD papers has become a de facto consensus when it comes to the issue of PD in Asia-Pacific context. No matter how much the contents of the Papers were watered down, Vietnam like other reluctant members had come to agree with PD, at least in principle.

${ }^{311}$ Ibid. 


\section{Did socialization work?}

Vietnam's endorsement of the PD papers seems to mark a sudden change in its preferences. Internal MOFA documents reveal that prior to the ARF SOM in May 2001 at which the adoption of the PD papers was decided, Vietnam's preference was to slow down the PD discussions, thus delaying the adoption of the PD documents. ${ }^{312}$ Why did Vietnamese participants suddenly change their position to agree with the adoption of the PD papers? Socialization theory provides three possible explanations for Vietnam's decision. First, it could be seen as an act of mimicking. As a novice in the ARF and in order to stay safe especially when the institution was in a period of transition - Vietnamese officials simply believed that they should act like others in the group, adopting the PD papers without being aware of the benefits of doing so. Second, it could be a result of social influence. Vietnamese officials came to agree with the adoption of PD papers because of social pressure from other in-groups. Specifically, they decided not to "rock the boat," joining the majority to approve the documents. A third explanation is that persuasion was at work and Vietnamese officials endorsed the PD papers because they found the arguments advanced by activist members convincing: they came to believe that the ARF, if equipped with PD measures, would be better able to respond to regional security issues.

\section{Persuasion as an explanation}

This section will follow Johnston's approach and look at the institutional environment and the characteristics of Vietnamese representatives to measure the extent to which these institutional and individual features are conducive to persuasion. It then examines whether persuasion was at work, making Vietnamese officials change their minds to go along with the adoption of the PD documents.

\footnotetext{
${ }^{312}$ MOFA ASEAN Department Report submitted to the Foreign Minister "On some issues relating to the ARF SOM in Hanoi, May 2001.” p. 2.
} 


\section{Working environment}

The working environment in the ARF's deliberations on PD had some features arguably conducive to persuasion. As Johnston suggests, an institution with deliberation as its mandate and consensus as its decision-making rule should help create a working environment that gives participants some degree of free choice and facilitates their flexible cognition when assessing counter-arguments. In Social States, Johnston points out that "flexible consensus" was one of the key institutional features that makes the working environment in the ARF conducive to persuasion. In his view, flexible consensus ensures that "the institution does not move far ahead of the interests of the most sceptical state" and "it is a logical mechanism for reassuring member states that the institution will not threaten sovereignty or national unity." 313 Flexible consensus is therefore conducive to persuasion in the sense that it helps create a non-threatening environment for potential targets of socialization.

The PD deliberations appear to have taken place in such an environment. For the reluctant group, careful and extensive deliberations on PD gave them an opportunity to raise their voice, express concerns and defend their positions. For the advocates, it was through these careful and extensive discussions that they wanted to show their respect for reluctant states and could reassure them about their concerns about PD's implications.

The message of reassurance by the activists was conveyed through the working procedures that required participants to submit their written comments to the mediators - Singapore, Japan and Korea - for revision before meetings were convened. With the written comments sent to all participants prior to ISG-CBM meetings, everyone knew well in advance the positions and attitudes of others. And the intervals between the two ISG-CBM meetings gave participants more time to reflect on and formulate their arguments on proposals and

${ }^{313}$ Johnston, Social States, 162. 
recommendations. The mediators then revised and circulated papers at meetings. Participants only needed to discuss those issues where there were differences as recommended by the mediators, so as to incrementally narrow the gaps and build common ground. In short, these working procedures were set up to give reluctant participants more time and a certain degree of free choice taking into consideration positions of the activists before deciding whether or not to hold their initial attitude and preferences. With these working procedures, reluctant participants would not feel under much pressure imposed by the activists.

Furthermore, the tone as reflected in written comments submitted by the activist members was milder than that in the previous speeches delivered by their respective leaders. For example, in 1998 Stanley Roth, the then Assistant Secretary of State for East Asia and the Pacific, called for the ARF members "to be prepared to surrender a degree of sovereignty for the greater good." ${ }^{314}$ His call reflected US frustration with the slow process of the ARF and at the same time aroused suspicion among reluctant states. However, US written comments in response to the PD Paper drafted by Singapore appeared more constructive. The US stated that "the ARF will need to maintain consensus and proceed at a pace comfortable to all. Attaining this goal will require compromise on the part of all participants so that the ARF is neither too slow nor too fast." ${ }^{315}$ Though Australia appeared similarly frustrated, its representatives also tried to soften the tone saying that "we should try to reach agreement on the three papers at the next ISG meeting in Kuala Lumpur, even if this means the 'agreed areas' of the papers are somewhat reduced." 316 Japan and Singapore, as activist members and mediators, were patient in engaging and accommodating China with a view to making

\footnotetext{
${ }^{314}$ Quoted in Brad Glosserman, "The United States and the ASEAN Regional Forum: A Delicate Balancing Act," 42.

${ }^{315}$ MOFA ASEAN Department Background Documents "US comments on Singapore's paper and Japan's paper" prepared for the 2nd ISG-CBM, Kuala Lumpur, Malaysia, April15-20, 2001.

${ }^{316}$ MOFA ASEAN Department Background Documents "Aide Memoire by Australia High Commission Singapore dated January 29, 2001" prepared for the 2nd ISG-CBM, Kuala Lumpur, Malaysia, April 15-20, 2001.
} 
progress on the drafted papers. By doing so, advocates expected that they would not be seen as trying to impose their positions on the reluctant members.

In such a non-threatening environment, novice Vietnamese officials might have found themselves under less pressure: submitting comments in written form meant they did not always have to engage in oral presentations where they might feel less confident. ${ }^{317}$ More importantly, they also had more time to carefully assess and judge the arguments of the advocates. This is significant from a persuasion perspective. As Johnston pointed out, flexible consensus does not only mean that the institution does not move far ahead of the interests of the most sceptical state, but it is also to "ensure that the most sceptical state cannot easily veto its evolution." 318 That means flexible consensus as a decision-making rule in a multilateral setting like the ARF also requires balancing between collective and national interests on the part of its members. As it was noted in chapter three, it is through the assessment of counter-attitudinal information and the recognition of the need to balance between collective and national interests that the Vietnamese participants had to carefully consider the implications of holding their initial attitude - opposing PD. Therefore, through this process - assessing arguments for PD and taking into consideration the protection of national interests but in a way that would not go against the collective interests of the institution - the probability of attitudinal change on the part of the Vietnamese might increase.

\section{Characteristics of Vietnamese participants}

The ARF's PD deliberations in 1997-2001 took place when Vietnam was still in its initial stage of regional integration characterized by the country's joining a number of regional institutions such as ASEAN, the ARF and APEC. Therefore, Vietnamese officials were real novices in the working environments of these institutions. Given noviceness is the key individual feature conducive to

\footnotetext{
${ }^{317}$ Internal documents reveal that Vietnamese officials as novices were often encouraged not to raise their voice or speak up on issues.

${ }^{318}$ Johnston, Social States, 162.
} 
socialization, it would be more likely for Vietnamese officials to endorse PD papers. However, what noviceness meant to Vietnamese participants needs to be worked out first.

In addition to capacity building, ${ }^{319}$ the key aspect of noviceness when it comes to interactions in the ARF in the early years was the lingering fear and suspicion on the part of the Vietnamese officials when working with their old enemies. $^{320}$ As Carlyle Thayer observed in the late 1990s, ideological conservatives in the Communist Party of Vietnam (CPV) feared "developing close political ties with non-socialist states and the impact this might have on domestic affairs. ${ }^{\text {321 }}$ He predicted that in Vietnam-US relations and in the ARF framework, it was the threat of peaceful evolution on the part of the Vietnamese that would impede progress in the area of political and security cooperation. ${ }^{322}$ Other scholars

\footnotetext{
${ }^{319}$ Capacity building in early years of participation in regional institutions, particularly in ASEAN, took different forms. On the one hand, hundreds of Vietnamese officials took part in intensive English courses both at home and abroad. On the other hand, Vietnam also started to test the waters by hosting a number of meetings and proposing initiatives, though not of paramount significance in substance. For example, Vietnam first hosted the $7^{\text {th }}$ Francophonie meeting in 1997. In 1998, it hosted the $6^{\text {th }}$ ASEAN Summit at a time when the region was plunged into a severe financial and economic crisis. In 2000-2001, Vietnam assumed the Chairmanship of the ASEAN Standing Committee (ASC) and of the ARF. This was the first time Vietnam hosted and chaired at the same time a total of about 20 meetings, including the $34^{\text {th }}$ ASEAN Ministerial Meeting, the $8^{\text {th }}$ ASEAN Regional Forum, ASEAN Plus Three Meeting, Post Ministerial Conference (PMC) Plus Ten and PMC Plus One. A MOFA report reveals that the number of those attending these meetings, including those involved in providing logistic support and event reporting was 2,378. On this occasion, Vietnam proposed the initiative on the narrowing of the development gap in ASEAN, which took the form of the Hanoi Declaration on Narrowing the Development Gap. This was the first initiative made by Vietnam in the early years of its participation in ASEAN.

${ }^{320}$ Ideology and the dichotomy of friends or foes have long played a dominant role in grouping and ranking partners and guiding the way Vietnam manages its cooperation with each group. This way of identifying friends or foes and later replacement with partners and objects of struggle was reflected in consecutive Documents of the CPV's National Congresses. For instance, the Documents of the IXth National Congress of the CPV in 2001 gave first priority to relations with socialist states (China) and neighbouring countries (China, Laos, and Cambodia) while developing multi-faced relationships with developed countries (the United States and other Western countries) and international organizations ranked fourth after traditional friends (Russia and India, for example). See "Documents of the Ninth National Congress of the Communist Party of Vietnam," Communist Party of Vietnam, 2001, hhtp://chinhphu.vn.

${ }^{321}$ Carlyle A. Thayer, "Vietnamese Foreign Policy: Multilateralism and the Threat of Peaceful Evolution," in Vietnamese Foreign Policy in Transition, eds. Carlyle A. Thayer and Ramses Amer (Singapore: Seng Lee Press Pte Ltd, 1999), 19-20.

${ }^{322}$ Ibid.
} 
made the same observation. According to Nguyen Manh Hung, Party conservatives were cautious about improving relations with the US given their fear of the threat of peaceful evolution indirectly triggered by the US policy on human rights and democracy. ${ }^{323}$ Alexander Vuving observed that under the leadership of Le Kha Phieu from 1997-2001, Vietnam "pursued a hard-line antiimperialism in foreign policy." 324 In particular, conservatives within the Party remained suspicious of the capitalist ASEAN partners and saw China as a strategic ally. This reality reflected the competition between anti-imperialists (or conservatives) and integrationists (or reformers) in the CPV in which the former sought to get closer to China and the later tried to make a counterbalance by strengthening relationships with the United States and other capitalist countries. ${ }^{325}$ However, in that period the anti-imperialists prevailed, getting closer to China. ${ }^{326}$

In the early years of participation in regional institutions such as ASEAN and the ARF, Vietnam's position or views essentially reflected those of the conservatives in the conduct of external relations who tended to interpret any actions on the part of the capitalist countries as attempts to interfere in their internal affairs. ${ }^{327}$ This way of seeing others thus determined Vietnam's assessment of arguments by PD advocates.

\section{Judging the intentions and arguments by PD advocates}

As the previous chapter showed, efforts by some established ASEAN members in the late 1990 s to relax the principle of non-interference were seen by

\footnotetext{
${ }^{323}$ Nguyen Manh Hung, "Vietnam in 1999: The Party Choice," Asian Survey 40, no. 1 (2000): 107.

${ }^{324}$ Alexander L. Vuving, "Strategy and Evolution of Vietnam's China Policy: A Changing Mixture of Pathways," Asian Survey 46, no. 6 (2006): 816.

325 Ibid. On how factions influenced Vietnam's foreign policy, see also Kent Bolton, "Domestic Sources of Vietnam's Foreign Policy," in Vietnamese Foreign Policy in Transition, eds. Carlyle A. Thayer and Ramses Amer (Singapore: Seng Lee Press Pte Ltd, 1999), 170-201.

${ }^{326}$ Vuving, 816-17. For Vietnam, the most notable achievements in its relationship with China in the late 1990s and early 2000s included the signing of the agreement on the land border in December 1999 and agreements on the demarcation of the Gulf of Tonkin and on fishery cooperation in December 2000.

${ }^{327}$ Interview by author in Hanoi, December 29, 2011.
} 
Vietnamese officials as attempts to interfere in others' internal affairs. The same situation was observed in the ARF in the early years of Vietnam's participation. Vietnamese officials found that the ARF in these years was in a "sensitive" transition period which could have negative implications for Vietnam's security and development. ${ }^{328}$ In particular, they found themselves in a disadvantageous position when participants from the United States, other Western countries and old ASEAN members attempted to move the ARF towards the next stage of PD and to institutionalize the forum.

MOFA documents prepared for the $7^{\text {th }}$ ARF in 2000 highlighted several major concerns. ${ }^{329}$ First, Vietnamese officials found themselves unprepared to move to the PD stage. They believed that as long as the foundation of the ARF confidence building - was not strongly built it was hasty to move on to PD. Hastening the ARF process might undermine mutual trust and confidence if not all participants are ready. Therefore, they proposed that the forum should continue to focus on implementing confidence building measures to further enhance and deepen mutual trust and confidence in order to create a solid foundation for further steps to be taken. Second, Vietnamese officials were of the view that the principles guiding the forum's operation were being challenged. Since the ARF was still in its early stage of development, these principles must be upheld, including the principle of evolutionary and step-by-step development, at a pace comfortable to all and decision making by consultation and consensus and voluntary implementation in accordance with the capacity of its participants. Third, in the Vietnamese perspective it was not realistic to institutionalize the ARF because it was a forum for regional political and security dialogue and cooperation rather than for conflict management. A highly institutionalized mechanism for political and security issues was arguably not suitable to the diversity of Asia and the Pacific and might be counter-productive. Therefore,

\footnotetext{
${ }^{328}$ Vietnam repeatedly stressed this sensitive transition period in numerous MOFA reports in intersessional year 2000-2001.

${ }^{329}$ MOFA ASEAN Department, "Talking points for the $7^{\text {th }}$ ARF in 2000."
} 
Vietnam's preference was to uphold the ARF's key principles and to prevent the forum from entering the PD stage and being institutionalized.

Given the perceived risks of taking up PD, Vietnamese officials from the outset of the PD deliberations carefully charted out their course of action. Regarding "ends", Vietnam aimed to "uphold key principles, to ensure that ASEAN is in the driving seat and that ARF is an evolutionary process in which confidence-building is the main thrust." 330 Government representatives believed that "their contribution to the substance of the meetings was to maintain and strengthen positive trends in ASEAN and the ARF that were in our national interests, and at the same time to minimize the negative implications of some other trends and issues, thus contributing to the creation of a favourable international environment for the country's economic development and security." 331 As for "means", internal documents suggested Vietnamese diplomats should "do our utmost to coordinate with those who share our views, thus opposing the early implementation of some PD measures and preventing attempts by some members to manipulate the ARF to interfere in internal affairs of others." 332 Vietnamese officials believed that their interests would be better secured by coordinating with like-minded participants.

As a result, officials were in a defensive posture throughout the PD deliberations. Numerous MOFA documents recommended Vietnamese officials not be the first to speak or should only speak if they were asked. ${ }^{333}$ Further, they were recommended to lobby or let others raise their voice first, particularly the hardliners such as the Chinese. ${ }^{334}$ They pursued a strategy of "not taking the lead,

\footnotetext{
${ }^{330}$ MOFA ASEAN Department Memo "On Our participation in the $33^{\text {rd }}$ ASEAN Ministerial Meeting," pp.1-2.

${ }^{331}$ Ibid.

${ }^{332}$ Ibid.

${ }^{333}$ MOFA ASEAN Department, "Talking points and Documents prepared for the $7^{\text {th }}$ and the $8^{\text {th }}$ ARF."

${ }^{334}$ MOFA ASEAN Department Memo dated April 4, 2001 "On Participation in the $2^{\text {nd }}$ ISG-CBM in Malaysia, April 15-20, 2001,"p. 3.
} 
not to be the last, not to be in the minority and not the only one to oppose.",335 They closely watched any moves on the part of major powers representing the two camps to decide how and the extent to which they should participate in the discussions. The ARF's developments and the state of PD discussions were regularly updated with special attention paid to the attitudes of the US participants on the one hand and the Chinese on the other.

Having identified with the reluctant group, Vietnamese officials saw the Chinese participants as a behavioural exemplar. As the chronology shows, Vietnamese officials shared concerns with their Chinese counterparts. For instance, they disagreed with the proposed convening of special sessions of the ARF SOM or Ministerial meeting to address an issue, arguing that the ARF is only a political and diplomatic forum for the exchange of views and that the institution provides enough occasions for such exchanges. ${ }^{336}$

As novices, Vietnamese participants might have enjoyed greater comfort to express their views in written form than in oral presentations. They also had a chance to compare the views of a wider group of participants, so as to fully develop their position and potentially build common ground on at least some issues on which views among participants were not too far apart. However, internal documents showed little evidence that Vietnamese officials came to accept the activists' message that moving the ARF on to the PD stage and employing specific measures would make the institution capable of responding to regional security issues in an effective and timely manner. Rather, given their distrust and suspicion of the activists' attempts to push PD forward, Vietnamese officials rejected almost all proposals they interpreted as potential pretexts to interfere in internal affairs. Therefore, they consistently sought to slow down

\footnotetext{
${ }^{335}$ Interview by author in Hanoi, December 29, 2011.

${ }^{336}$ MOFA ASEAN Department Background Documents "China's written comments on Singapore's Paper dated January 9, 2001" prepared for the 2nd ISG-CBM, Kuala Lumpur, Malaysia, April15-20, 2001.
} 
discussions and delay the adoption of the PD papers. Indeed, MOFA documents prepared for the 7th ARF in July 2000 suggested Vietnam's position as follows:

We should state that confidence building measures are the foundation and the main thrust of the ARF. Therefore, focus must be on the continued implementation of CBMs, rather than on moving on to the PD stage. ARF's key principles must be upheld, including the principle of evolutionary and step-by-step development, decision making by consultation and consensus and voluntary implementation. ASEAN must play the leading role, especially as the ARF Chair. We should push forward the continued implementation of CBMs, seeking ways to slow down and prevent the ARF from moving on to PD stage and being institutionalized. We do not oppose the discussions on PD concept and principles and the measures in overlap. However, on the four measures in overlap we should try to minimize the scope and the extent of these measures and that the implementation of these measures should be on a voluntary basis. ${ }^{337}$

In order to delay PD discussions, MOFA documents prepared for the 7th ARF encourage Vietnamese participants to do the following: (i) to raise our concerns on a number of issues, including the third PD objective (preventing such disputes and conflicts from spreading geographically), specific measures such as the role of ARF Chair, and even general PD principles; (ii) to argue that the third objective was vague and could be used to interfere in internal affairs of others; (iii) to stress the need to uphold the principles of consultation and consensus in response to Western countries' proposal for the PD exercise in a timely manner.

MOFA documents prepared for the 7th ARF also suggested that while acknowledging that reaching agreement on the PD concept and principles would serve as a basis for moving the ARF on to the next stage, Vietnamese participants should stress that if this paper were adopted it would not be a legal document. Rather, it would only be a document that reflected a shared understanding of PD among participating countries and would be applicable to the ARF only, given regional differences. Vietnamese participants feared that they would be tied to

${ }^{337}$ MOFA ASEAN Department Background Documents, dated July 10, 2000 "On the ARF" prepared for the $7^{\text {th }}$ ARF meeting, p.2. Emphasis added. 
binding decisions in political and security areas. Therefore, they repeatedly stressed that the ARF was a forum for political and security dialogue and cooperation. They also believed that if the paper on the concept and principles of PD was a document reflecting shared understanding it would be easier to be modified later. ${ }^{338}$

Regarding the enhanced role of the Chair, Vietnamese diplomats were of the view that its functions and scope of actions should be limited. MOFA documents prepared for the 7th ARF encourage Vietnamese officials to seek ways to delay the adoption of Japan's paper by opposing "late PD measures" initiated by the US and other Western countries such as mediation and the formation of fact-finding missions. A similar stand was recommended on the Register of the EEPs. The same MOFA documents prepared for the $7^{\text {th }}$ ARF suggested Vietnam's officials:

[We should try] to slow down this process and to minimize the role, functions and scope of activities of this group. Therefore, we should propose to clarify since the outset the EEPs' functions, principles and scope of their actions. We uphold the principles of voluntary implementation, with the consent of all participants, and non-interference in internal affairs of others. The EEPs' functions and scope of actions should be limited to making non-binding professional advice and recommendations and carrying out indepth studies. The EEPs should not be encouraged to play the role of mediators and their operation should be on an ad hoc basis. ${ }^{339}$

Vietnam's efforts to slow down PD discussions can also be observed at the ISG-CBM held in Seoul, Korea in November 2000. In a cable message sent to Hanoi from the Vietnamese Embassy in Seoul, it was reported that before the meeting took place Vietnamese officials acting as the Chair of the ASEAN Standing Committee (ASC) and the ARF held separate meetings with the two cochairs (Korea and Malaysia) and delegations from the US, China, Singapore and Thailand to exchange views and discuss the issues to be examined at the ARF

\footnotetext{
338 Ibid.

${ }^{339}$ Ibid., 6
} 
meetings in Hanoi in $2001 .^{340}$ Due to divergent views, it was decided that the meeting would not discuss the three PD papers. Rather, participating countries were requested to submit their written comments for further revision. The fact that the ISG-CBM in Seoul did not discuss the three papers was considered by the Vietnamese participants as a success in their efforts to slow down PD discussions. $^{341}$

Prior to the ISG-CBM in Kula Lumpur in April and the ARF SOM in Hanoi in May 2001, Vietnam's position remained essentially unchanged. In a MOFA report submitted to the Foreign Minister in preparation for the ARF SOM, it was stressed that Vietnam should continue to delay the adoption of the first two PD papers, thus preventing the ARF from moving on to the second stage. Only a minor change occurred with the paper on the Register of the EEPs. It was proposed that "if the paper is revised, clarifying the financial issue and other participating countries agree with it, so we could support its adoption at the meeting, thus making a progress in the ARF process." 342

In short, prior to the ARF SOM in May, Vietnamese officials tried to prevent the adoption of the papers on the PD concept and principles and on the enhanced role of the Chair. Fearing that the ARF could be manipulated by activist members to interfere in internal affairs, Vietnamese officials were deeply cautious about PD. The belief that they were not the only ones to hold this view also helped them maintain this position. As a result, Vietnamese officials did not feel under much pressure to endorse PD papers. These factors thus impeded the effects of persuasion in eliciting cooperation from Vietnamese representatives.

\footnotetext{
${ }^{340}$ MOFA ASEAN Department, Cable massage no. 154 HT dated November 3, 2000 "On the ISG-CBM, Soul, Korea, November 1-3, 2000."

${ }^{341}$ Ibid.

${ }^{342}$ MOFA ASEAN Department Report submitted to the Foreign Minister "On some issues relating to the ARF SOM in Hanoi, May 2001," p. 4.
} 


\section{Social influence as an explanation}

A social influence explanation for Vietnam's eventual endorsement of PD papers argues that since Vietnamese officials looked toward their Chinese counterparts and to some extent those from Russia and India as a reference group, the latter's attitudinal change to become more cooperative on PD helped elicit similar change on the former. Put differently, social influence suggests that Vietnamese officials found themselves in a minority when other like-minded ones changed their position. Not wanting to rock the boat, they followed like-minded participants by endorsing the PD papers, though knowing that their decision would later bring about negative consequences.

There is some evidence in favour of a social influence explanation. After Vietnam assumed the Chairmanship of the ARF in July 2000 its representatives continued to strictly follow the strategy of coordinating with other reluctant members and closely watching any moves on the part of the Chinese. The seemingly unchanged attitudes on the part of China, Russia and India prior to the ARF SOM in May 2001 consolidated Vietnam's perception that divergent views on PD papers could not be bridged any time soon and so it would not be easy for PD to move forward. A MOFA Memo prepared for the $2^{\text {nd }}$ ISG-CBM in April 2001 noted that "China was still cautious and wanted to focus on CBM, and resolutely opposed moving $\mathrm{ARF}$ on to $\mathrm{PD}$ stage and institutionalizing the forum." ${ }^{343}$ Against this backdrop, the then Vietnamese Deputy Foreign Minister and ASEAN SOM Le Cong Phung was of the view that PD could not be moved forward. He instructed Vietnamese officials "not to raise our voice." $344 \mathrm{He}$ also recommended, "in the role of the Chair, we should only sum up the meeting, stressing that due to the lack of agreement we should focus on CBMs and

\footnotetext{
${ }^{343}$ MOFA ASEAN Department Memo dated April 4, 2001 "On participation in the $2^{\text {nd }}$ ISG-CBM in Malaysia, April 15-20, 2001."

${ }^{344}$ Ibid., p. 3.
} 
continue to work on PD. ${ }^{345}$ Vietnamese officials therefore did not anticipate any possible change on the part of China and other reluctant members at the ARF SOM in May.

However, at the May ARF SOM, China suddenly changed its position to endorse the three PD papers, thus leading to consensus among the participants on the adoption of these papers. Dang Dinh Quy - a senior official at MOFA who attended the ARF SOM in Hanoi - confirmed the shift on the part of the Chinese and acknowledged that Vietnam's efforts to delay the adoption of these papers had failed. ${ }^{346}$ As Dang observed, "China's changed attitude came as a shock" and the then ASEAN SOM Le Cong Phung, who chaired the meeting, found himself in a very difficult situation because Vietnamese officials failed to anticipate such change by the Chinese. ${ }^{347}$ China's changed attitude helped generate consensus among major powers on the adoption of the PD papers. ${ }^{348}$ Since the role of ASEAN in agenda setting, as Rizal Sukma has observed, is limited to taking "an accommodation position vis-à-vis the preferences of major powers, "349 Vietnam

\footnotetext{
${ }^{345}$ Ibid.

${ }^{346}$ Interview by author in Hanoi, February 24, 2012.

${ }^{347}$ Dang also said that failing to prevent the adoption of PD papers, Vietnam pushed forward the proposal of narrowing the development gap in ASEAN so as to make it an imprint during its chairmanships of the ASC and the ARF. The Hanoi Declaration on Narrowing Development Gap for closer ASEAN Integration was the first initiative made by Vietnam in the ASEAN cooperation framework.

${ }^{348}$ It was not clear why Chinese officials suddenly changed their attitude toward more a cooperative one on PD as evidenced at the ARF SOM in May. Dang Dinh Quy saw China's move as a manifestation of its charm offensive strategy in the early 2000s to show a more active role in multilateral settings. It could also be that the progress in bilateral relationships between major powers around mid 2001 indirectly helped facilitate their cooperation in multilateral settings. A MOFA report of the results of a series of meetings held in Vietnam that year took note that these meetings were held in an important context in which major powers made policy adjustments to manage disagreements and stabilize their bilateral relationships. For example, China made efforts to stabilize its relations with the US after the collision on the $1^{\text {st }}$ April between an American EP-3 reconnaissance plane and a Chinese naval fighter. To its turn, the US by the end of May granted China an extension of normal trade relations (NTR) status. Russia and China refrained from criticizing the US national missile defence (NMD). On US-China Relations in 2001, see Dali L. Lang, "China in 2001: Economic Liberalization and Its Political Discontents," Asian Survey 42, no. 1 (2002): 14-28; Kenneth Lieberthal, "The United States and Asia in 2001: Changing Agendas," Asian Survey 42, no. 1 (2002): 1-13.

${ }^{349}$ Sukma, "The Accidental Driver: ASEAN in the ASEAN Regional Forum," 114.
} 
had no choice as Chair but to follow the major powers and adopt three papers as a part of the $8^{\text {th }}$ ARF's agenda.

Consensus reached on the adoption of three papers at the ARF SOM in May was later confirmed in a MOFA Document prepared for the 8th ARF in Hanoi, July 2001, which stated that "after the three papers are adopted the US and some Western countries want the meeting to focus on the completion of CBMs and the implementation of the two papers on the enhanced role of the ARF Chair and the Register of the EEPs." ${ }^{350}$ Another MOFA document prepared for Vietnam to be the co-chair of ISG-CBM with India from July 2001 to July 2002 also took note that "those who were previously reluctant on PD such as China, India, and Russia now changed their attitude toward more supportive of the implementation of measures in overlap between CBMs and PD, including moving on to PD stage.",351

In addition to the impact of China's attitudinal change, image concerns as the ARF Chair played a part in eliciting more cooperative behaviour on the part of the Vietnamese officials. Indeed, they were sensitive not to be seen as blocking the process or making impossible some progress in the ARF process. Internal documents revealed that Vietnamese officials found themselves in a dilemma when assuming the ARF Chair. On the one hand, they believed that something had to be done to facilitate the ARF's process if it were to remain relevant. On the other hand, they also sought ways to slow down PD discussions and delay the adoption of PD papers, thus preventing the ARF process from entering the PD stage. These proved to be difficult tasks when the ARF was in a complicated transition period and the voice of ASEAN was weak in the international arena. ${ }^{352}$

\footnotetext{
${ }^{350}$ MOFA ASEAN Department Memo, "On Chairing the $8^{\text {th }}$ ARF," p. 5.

${ }^{351}$ MOFA ASEAN Department Memo dated August 29, 2001 "On one year Vietnam works as cochair of the ARF ISG-CBM," p.1.

352 MOFA ASEAN Department Memo, no. 62-TTr/BCS-ASEAN-m dated July 12, 2000 “On Participation in the $33^{\text {rd }}$ ASEAN Ministerial Meeting," p.1.
} 
Vietnamese officials found that this situation would challenge Vietnam's successful chairmanships of the ASC and the $8^{\text {th }}$ ARF. ${ }^{353}$

As a result, they had to take into consideration those items on which their position should be adjusted or flexible. For example, prior to the $7^{\text {th }}$ ARF in July 2000, Vietnam's position was to slow down PD discussions and delay the adoption of the paper on the concept and principles of PD by raising its concerns on some issues such as the third objective, the role of the ARF Chair and principles. However, it was also suggested that the position on these issues might be subject to change when Vietnam officially took up the Chair. ${ }^{354}$ Vietnamese officials were also encouraged to reconsider the publication of the Annual Security Outlook which their preference was to delay by raising technical and financial difficulties as the main obstacle for unpreparedness. ${ }^{355}$ In preparation for the ISG-CBM in Kuala Lumpur in April 2001 Vietnam's position was stated as follows:

[On the one hand] We should skilfully prevent the ARF from moving towards PD and being institutionalized, avoiding the formation of binding mechanisms whereby we would be put in a disadvantageous situation on political and security areas or that can be used to interfere in our internal affairs and have negative impacts on the ASEAN's role; we should restate that the ARF should focus on confidence building and this would be the main thrust of the ARF process, and we should work together with other ASEAN members to resolutely maintain its role as the driving force of the $A R F{ }^{356}$

On the other hand, acting as the ARF Chair, we should show our flexibility thus creating the impression that, rather than blocking it, Vietnam is working to move the ARF in the right direction and trying to make progress on those issues that are less sensitive. We should coordinate with the two co-chairs in order to make some progress on the papers on PD, the enhanced role of the ARF Chair and the Register of the EEPs. The remaining two documents might be more complicated and their adoption is

\footnotetext{
353 Ibid.

${ }^{354}$ MOFA ASEAN Department Background Documents dated July 10, 2000 "On the ARF" prepared for the $7^{\text {th }}$ ARF meeting in July 2000," p. 5.

355 Ibid.

${ }^{356}$ Original italics.
} 
less likely. In so doing, the meeting could make some progress in the deliberations and report to the ARF SOM in May, 2001. ${ }^{357}$

This position was reaffirmed in a MOFA memo prepared for the ASEAN Ministerial Meeting (AMM Informal Retreat) in Rangoon, Myanmar on 30 April 2001 which read:

[On the ARF] our position is to prevent the ARF from moving on to the next stage and being institutionalized, to restate CBMs should be the main thrust of the process, to uphold ARF's core principles and to maintain the role of ASEAN as the driving force. However, in the role of the ARF Chair, we should also show our flexibility on some issues that are not in principle. $^{358}$

At the ISG-CBM in Kuala Lumpur, the Vietnamese diplomats were recommended not speak up or to take the lead in opposing the PD papers, thus creating the impression that Vietnam wanted to block the process. In addition, Vietnamese diplomats were encouraged to show their flexibility on the revised paper on the Registration of the EEPs which was seen as in Vietnam's interests given the mandate of experts was limited to doing research and make non-binding recommendations. Vietnam saw no major disagreement among a majority of ARF members on this paper. Thus it was suggested that if financial arrangements could be clarified, Vietnam could follow the majority to adopt the paper so as to make some progress in the ARF process. ${ }^{359}$

Image concerns as the ARF Chair determined to a certain extent the flexibility on the part of Vietnamese officials toward PD papers, particularly the Register of the EEPs. However, Vietnam's decision to go along with PD was primarily because of the change on the part of the Chinese as representative of the reluctant group toward cooperating with activist members in moving PD forward. Given their limited role in setting the ARF agenda, Vietnamese officials had to

\footnotetext{
${ }^{357}$ MOFA ASEAN Department Memo dated $4^{\text {th }}$ April, 2001 prepared for the $2^{\text {nd }}$ ISG-CBM, Malaysia April15-20, 2001.

${ }^{358}$ MOFA ASEAN Department Memo dated April12, 2001 "On chairing the AMM Retreat, Rangoon, Myanmar, April 30, 2001,” p. 4. Emphasis added.

${ }^{359}$ Ibid. p. 4.
} 
accommodate the preferences of major powers. In addition, not rocking the boat and joining the majority to adopt PD papers was in line with the guiding principle that Vietnamese officials set out in conducting external relations, particularly in engaging in PD deliberations: never be in the minority.

\section{Conclusion}

Persuasion did not elicit cooperation on the part of the Vietnamese in this case. A working procedure which should have been conducive to persuasion did not facilitate the assessment among Vietnamese officials of the arguments for PD so as to narrow differences and build common ground. On the contrary, the deliberative process actually helped them slow down PD discussions and delay the adoption of PD papers. Noviceness and a deliberative working environment, as the key individual and institutional features arguably conducive to persuasion, did not exert much influence in eliciting cooperative behaviour on the part of the Vietnamese as theory would expect. Rather, the perceived risks of change determined the way Vietnamese officials interacted and pursued their objectives. Because of their distrust and suspicion of activist states, Vietnamese officials carefully set out their objectives and actions and strictly followed these throughout the PD deliberations.

Another important factor that impeded the effects of persuasion was that Vietnamese officials were not the main target for the activist members. China was the primary focus of their efforts. Indeed, it was widely observed that in the early years of participation in the ARF, Western countries aimed to engage China in multilateral security norms and practices. ${ }^{360} \mathrm{PD}$ deliberations were an example of such effort. The chronology clearly showed Singapore and Japan in their

\footnotetext{
${ }^{360}$ Glosserman, "The United States and the ASEAN Regional Forum: A delicate Balancing Act," 48; China was an important factor for the formation of the ARF, see among others, Mely Caballero-Anthony, Regional Security in Southeast Asia: Beyond the ASEAN Way (Singapore: Institute of Southeast Asian Studies, 2005), 121-123; Severino, Southeast Asia in Search of an ASEAN Community, 189-98.
} 
mediating role worked primarily with Chinese officials as representatives of the reluctant side in revising the proposed papers. As Yuzawa observed, Japanese officials even visited Beijing to discuss the paper with their Chinese counterparts and to reconcile differing views. ${ }^{361}$ They even made concessions to the Chinese preferences so as to facilitate the deliberations.

In such circumstances, one might argue that perhaps there was persuasion but the activist states persuaded China rather than Vietnam though the latter was also in the reluctant camp. They may suggest that Vietnam would have been persuaded if activist countries put all their efforts into persuading Hanoi rather than Beijing. This seems unlikely because as was noted in the previous sections, Vietnam in the 1990s remained suspicious of capitalist countries and saw China as a behavioural exemplar. A senior Vietnamese official admitted in an interview that in that period "Vietnam looked toward and followed China in formulating its positions on major international issues." 362

Still others might even go further, arguing that activists such as the US and Japan might have offered some material incentives and these were made on other occasions (such as bilateral meetings) unrelated to the ARF in exchange for Vietnam's support for the adoption of PD papers. This argument does not hold, however. Realities show that, to a large extent, Vietnam has successfully delinked and pursued economic and trade cooperation from political and security issues. Vietnam-US bilateral relationship is a case in point. In 1999-2000 when PD deliberations were going on, Vietnam and the US were also negotiating for a bilateral trade agreement. However, this agreement was signed in 2000, one year before ARF members reached consensus on the adoption of PD papers. ${ }^{363}$ Thus,

\footnotetext{
${ }^{361}$ Yuzawa, "The Evolution of Preventive Diplomacy in the ASEAN Regional Forum," 796.

${ }^{362}$ Interview by author in Hanoi, December 29, 2011.

363 "Chronology of key Events in U.S. - Vietnam Relations," Embassy of the United States, accessed April 12, 2014, http://www.usvtc.org/us-vietnam/Chronology/Chronology\%20of\%20USVN\%20Relations\%2022May08.pdf.
} 
the possibility that the US had placed progress on this bilateral trade agreement as conditionality in exchange for Vietnam's cooperation in political and security area in the ARF can be ruled out.

Similarly, Vietnam-Japan economic and trade cooperation has gone smoothly without any pressures from the Japanese side arising from political and security issues. Indeed, Japan has long been the largest ODA donor for Vietnam. ${ }^{364}$ The only exception was in 2008 when the former suspended its ODA provision for the latter. However, this was due to a corruption scandal involving a Japanese company and the suspension did not last for long. Japan then announced to resume ODA to Vietnam in early $2009 .{ }^{365}$ Generally, Vietnam-Japan bilateral relations have been described as "problem free" and if there is any, it is primarily technical one. ${ }^{366}$

Social influence appears to be the most plausible explanation for Vietnam's endorsement of the PD papers. Choosing China as a behavioural exemplar, the Vietnamese participants in the chairmanship of the ARF had no choice but to follow their Chinese counterparts when the latter suddenly changed its position and supported the adoption of PD Papers. In this sense, Vietnam's decision to adopt the PD papers was an act of mimicking - copying the behaviour of others - but not in the strict sense Johnston suggests, that is, to survive in a novel environment. Rather, mimicking in the ARF case came as a result of social pressure because in the capacity of the ARF Chair Vietnam would be seen as blocking the process if it opposed the adoption of PD documents. As the ARF

\footnotetext{
364 "Vietnam - Japan Relations," the Vietnamese Government, accessed April 12, 2014. http://chinhphu.vn/portal/page/portal/chinhphu/NuocCHXHCNVietNam/ChiTietVeQuocGia?dipl omacyNationId=267\&diplomacyZoneId $=85 \&$ vietnam $=0$.

365 "Japan resumes ODA to Vietnam," Asia Economic Institute, accessed April 12, 2014, http://www.asiaecon.org/special_articles/read_sp/12808.

${ }^{366}$ For a review of Vietnam-Japan relations, see among others, Thi Binh Khong, "China-VietnamJapan: A Strategic Triangle?" in Southeast Asia between China and Japan, eds. Lam Peng Er and Victor Teo (Cambridge Scholars Publishing, 2012), 123-142.
} 
Chair, Vietnam had to accommodate the preferences of major powers to adopt the PD papers as a part of the forum's agenda.

However, following China to adopt these documents did not lead to change in Vietnam's preferences. Rather, in ARF meetings since the $8^{\text {th }}$ ARF Vietnamese officials have continued to seek to prevent the ARF from entering the PD stage by slowing down the implementation of the papers on the enhanced role of the Chair and on the Register of EEPs which the activist members saw as the operational side of PD in Asia-Pacific region.

As mandated at the $8^{\text {th }}$ ARF, Vietnam and India co-chaired the ISG-CBM from July 2001 to July 2002. Although efforts to delay the adoption of PD papers failed, Vietnam's preference to slow down the ARF's transition period from stage I to stage II remained unchanged. A MOFA Memo prepared for the first ISGCBM in New Delhi, December 2001 noted that the implementation of the three papers and PD measures would be on the top of the meeting agenda and recommended:

[On the Paper on Concept and Principles of Preventive Diplomacy] we should slow down the discussions on these papers, thus delaying ARF moving on to PD. We should ask Malaysia as the co-chair of the previous ISG-CBM to inform the meeting of the divergent views on the PD paper so that participants could continue their discussions with a view to building a shared understanding. We should only listen to others. If requested to discuss it in detail, we should reaffirm that we only agree with the first two objectives. The third objective belongs to the third stage. ${ }^{367}$

Arguments against the implementation of the paper on the enhanced role of the ARF Chair and the paper on the Register of EEPs also remained unchanged. Vietnamese diplomats at this meeting also feared that after the 9/11 terrorist attacks some participants could raise again the possibility for the ARF Chair to convene special meetings in emergency situation. They were also

${ }^{367}$ MOFA ASEAN Department Memo dated December 5, 2001 "On the Co-Chairmanship of the first ISG-CBM, New Delhi, December 19-21, 2001”, p. 3. 
reminded that previously Chinese participants had strongly opposed this proposal. Thus Vietnamese diplomats were recommended not to speak up on the issue. ${ }^{368}$ However, the co-chair's summary report of the ISG-CBM in New Delhi showed no progress on PD discussions. Instead, counter-terrorism became a dominant issue for regional discussion and cooperation. ${ }^{369}$ On the ARF's activities, it was reported in a MOFA document that "those were previously cautious about ARF evolution now appeared more flexible. China announced that it would be more open and actively participate in the ARF process. However, the priority is now given to counter-terrorism, thus ARF is not yet moving on to PD stage and being institutionalized." 370

As a result, there was no more substantial progress on PD in subsequent ARF meetings. Prior to the $15^{\text {th }}$ anniversary of the institution in 2008, there was an urgent call to move the ARF forward, particularly embarking on the second stage of PD. ${ }^{371}$ At the $15^{\text {th }}$ ARF in Singapore on July 24, 2008, the ARF adopted the Singapore Declaration in which ARF members committed to "further the

\footnotetext{
368 Ibid.

369 "Co-Chairmen's Summary Report of the Meetings of the ARF Inter-sessional Support Group on Confidence Building Measures,” ASEAN Regional Forum, New Delhi, December 19-21, 2001 and Hanoi, April 22-24, 2002, http://aseanregionalforum.asean.org/library/arf-chairmansstatements-and-reports/165.html. In 2003, the ARF formed an Inter-sessional Group on CounterTerrorism and Transnational Crime which was co-chaired by the US and Malaysia. In addition, impacts of the Iraq war in 2003 also contributed to the development of the ARF agenda on terrorism.

${ }^{370}$ MOFA Report no. 473-BC/NG-ASEAN-m submitted to the Prime Minister dated August 9, 2002 "On the Results of the $35^{\text {th }}$ AMM/the $9^{\text {th }}$ ARF/PMC, Brunei from July 28 to August 1, 2002."

371 For example, at the ARF Workshop on Confidence Building Measures and Preventive Diplomacy in Asia and Europe held in Berlin, March 12-14, 2008 co-chaired by Indonesia and the EU, Singaporean participants argued that what the ARF achieved on PD was not sufficient to reach veritable preventive diplomacy and that ARF was now at a "transition period" and PD cannot be achieved without enhancing ARF institutional capacity. They suggested (i) clarification of the role of ASEAN and non-ASEAN participants; (ii) focusing ARF's activities on key areas; (iii) enhancing concrete, practical cooperation; (iv) streamlining decision-making; (v) strengthening ARF Chair; (vi) maintaining "flexible moratorium" on membership; and (vii) enhancing cooperation with Track Two and external organizations. Meanwhile, other participants, such as Indonesia, were more cautious about moving toward PD. They stressed three principles of sovereign equality, territorial integrity and non-interference in the internal affairs and argued that the ARF's concept of preventive diplomacy would therefore be different from that of former UN Secretary-General Kofi Annan, for example.
} 
development of appropriate Preventive Diplomacy concepts" while ensuring that "future development would continue to be based on the values and roadmap contained in the 1995 ARF Concept Paper, 2001 ARF Concept and Principles of Preventive Diplomacy, and Paper on the Review of the ARF." 372

Vietnam was more supportive of PD in 2010 when the country assumed the chairmanship of ASEAN and the ARF. While the Vietnamese representatives continued to emphasize the importance of the ARF as the main forum for regional political and security dialogue and cooperation and of CBMs as the main thrust of the ARF process, they endorsed the implementation of some PD measures if these were "appropriate and feasible." 373 Assuming the $17^{\text {th }}$ ARF Chair, Vietnamese officials had to handle the implementation of the ASEAN Regional Forum Vision Statement and thus they were expected to propose some PD measures. However, internal debates reveal that two related issues emerged in debating what PD measures to be proposed which included: (i) scope of cooperation and (ii) intrastate PD measures. Vietnamese officials were more concerned with the second issue. ${ }^{374}$ As a result, it was decided to develop and implement an ARF PD work plan which was later incorporated into the Hanoi Plan of Action to Implement the ASEAN Regional Forum Vision Statement but without any substance. ${ }^{375}$ The task to work out the substance of an ARF Preventive Diplomacy Work Plan was left to Singapore.

The adoption of an ARF Preventive Diplomacy Work Plan at the $18^{\text {th }}$ ARF in 2011 was the most recent development in the ARF's slow move to its second

\footnotetext{
372 "Singapore Declaration on the $15^{\text {th }}$ ARF," ASEAN Regional Forum, July 24, 2008, http://aseanregionalforum.asean.org/library/arf-chairmans-statements-and-reports.html.

${ }^{373}$ MOFA ASEAN Department Report no. 930/TTr-BNG-ASEAN-m dated June 11, 2010 "On the Contents of the $43^{\text {rd }}$ AMM and Related Meetings," p. 2.

${ }^{374}$ Interview by author in Hanoi, December 29, 2011.

375 "Hanoi Plan of Action to Implement the ASEAN Regional Forum Vision Statement," ASEAN Regional Forum, May 20, 2010, http://aseanregionalforum.asean.org/library/arf-chairmansstatements-and-reports.html.
} 
phase. $^{376}$ However, PD activists would be disappointed with the list of PD measures, given that they are all about confidence building. Approaches that might be considered closer to a traditional understanding of PD, such as mediation, are proposed only as long-term measures. The adoption of the Work Plan should therefore be seen as a largely cosmetic response to recent calls for the ARF to be a more action-oriented institution or else risk irrelevance. It does not reflect serious efforts among participants to embark on PD. Indeed, there are echoes of 1999-2001 when the ARF Concept and Principles of PD was adopted in order to deflect similar criticism of the Forum.

${ }^{376}$ The Work Plan can be accessed at http://www.aseanregionalforum.org. 


\section{CHAPTER VI}

\section{THE UNITED NATIONS SECURITY COUNCIL AND THE RESPONSIBILITY TO PROTECT}

This chapter examines if Vietnam's endorsement of the Responsibility to Protect (RtoP) was a result of socialization in the United Nations Security Council (UNSC). The chapter begins with an overview of RtoP's evolution and Vietnam's position as a non-permanent member of the Security Council for the 2008-2009 term. The chapter then explores persuasion, social influence and mimicking as the three possible explanations. A persuasion explanation argues that through deliberations, Vietnamese officials came to judge that RtoP was justified and that positive attitudinal change was then reflected in public statements. Conversely, a social influence explanation argues that the decision to go along with RtoP was made to build an image of Vietnam as a responsible member of the world community and to "not rock the boat." A third explanation - mimicking - argues that as novices at the Security Council, Vietnamese representatives adopted RtoP in order to adapt to the new working environment and that they did so without clear understanding of the costs and benefits.

Contrary to the findings in the two previous chapters where social influence proved to be the most plausible explanation for Vietnam's decision to accept the ASEAN Human Rights Body and Preventive Diplomacy Documents, this chapter argues that combined effects of mimicking, social influence and persuasion help explain Vietnam's endorsement of RtoP. In particular, mimicking and social influence occurred and paved the way for persuasion to occur over time: accepting RtoP in principle and engaging in the deliberations and resolutions of RtoP-related issues gradually helped Vietnamese officials gain a better understanding of RtoP as a concept. They saw it as less threatening than 
they had done and then became convinced of the rightness and the necessity of RtoP in the world today.

However, for the purpose of delineating their social effects, the chapter examines these processes in separate sections. There is some evidence that persuasion was at work and that as a result Vietnamese representatives saw RtoP as less threatening than they had done, and they became more comfortable with the concept. This attitudinal change came via two routes. First, participation in Security Council deliberations helped Vietnamese officials gain a better understanding of RtoP as a concept and thus removed some of their fear of its implications. Second, with personal experience drawn from involvement in a number of potential RtoP situations, Vietnamese officials came to judge that RtoP was necessary. This positive attitudinal change was observed among a small group of Vietnamese officials directly working at the Security Council.

A social influence explanation sheds light on Vietnam's endorsement of RtoP in an indirect way. Unlike the social influence instances we have seen in the two previous chapters, there was no single, critical moment when Vietnamese officials found themselves under pressure to make a sudden change from opposing to supporting RtoP. Rather, Vietnam's decision to go along with RtoP was to join its reference group which included members from the Non-Aligned Movement (NAM) and other like-minded states who already endorsed the norm, though to varying degrees. In addition, the decision was taken in a context where the country's leadership saw the non-permanent membership at the UNSC as an opportunity to build the image of Vietnam as a responsible member of the international community. Opposing RtoP would undermine such a social goal and put the country in a minority group - a situation that officials had long sought to avoid as a guiding principle of conducting external relations in general. 
Mimicking was also at work. Being novices in the working environment of the Security Council, Vietnamese officials had to follow their counterparts to participate in RtoP deliberations. They started using the general RtoP language without a clear understanding of the concept. They did not have clear preferences over it upon the entry into the deliberations either. Participation in discussions and using RtoP language even without prior knowledge of costs or benefits of doing so was an effort on the part of Vietnamese officials to adapt to a new working environment and expose themselves to a new issue.

\section{The evolution of RtoP and Vietnam's position}

The origins of RtoP and its development from an idea to a new international norm have been extensively studied. ${ }^{377}$ As Weiss and Thakur observe, "no idea has moved faster in the international normative arena than the responsibility to protect." ${ }^{378}$ RtoP was first introduced in the eponymous 2001 report of the International Commission on Intervention and State Sovereignty (ICISS, hereinafter the Commission). ${ }^{379}$ The report was a response to the call by the UN Secretary-General Kofi Annan for international consensus on the use of coercive action to respond to situations when gross and systematic violations of human rights take place. ${ }^{380}$ The Commission first reformulated the debate of how to reconcile sovereignty and intervention by reconceptualizing sovereignty as responsibility, which included an external responsibility to respect the sovereignty of other states and an internal responsibility to respect the dignity and basic rights

\footnotetext{
377 See for example, Alex J Bellamy, "Wither the Responsibility to Protect? Humanitarian Intervention and the 2005 World Summit," Ethics and International Affairs 20, no. 2 (2006):143171; Alex J. Bellamy, "The Responsibility to Protect: Five Years On," Ethics and International Affairs 24, no. 2 (2010):143-169; Thomas G. Weiss and Ramesh Thakur, Global Governance and the UN: An Unfinished Journey (Bloomington: Indiana University Press, 2010); Special Issue: Responsibility to Protect in Asia, The Pacific Review no. 1 (2012): 1-173.

${ }^{378}$ Weiss and Thakur, Global Governance and the UN: An Unfinished Journey, 308.

${ }^{379}$ ICISS was established by the Canadian Government in 2000 and operated as an independent research institution.

380 "The Responsibility to Protect," International Commission on Intervention and State

Sovereignty, December 2001, http://responsibilitytoprotect.org/ICISS\%20Report.pdf.
} 
of all the people within a state. ${ }^{381}$ With a focus on the latter aspect of sovereignty the protection of a state's population - the Commission said that states bear the primary responsibility, but in a case where a state is unable or unwilling to fulfil its responsibility, or is itself the perpetrator, then it becomes the responsibility of the international community to act in its place. ${ }^{382}$ The Commission proposed that the international community, in order to exercise its responsibility to protect, could take a wide range of measures, including military action as a last resort and subject to criteria including right authority, just cause, right intention, proportional means and reasonable prospects.

However, the introduction of RtoP in the ICISS's report was overshadowed by the 11 September terrorist attacks in the United States and the subsequent war on terror. In 2004, RtoP was reintroduced in the report of the United Nations High-level Panel on Threats, Challenges and Change. ${ }^{383}$ Formed in 2003 at the request of the UN Secretary-General Kofi Annan, the High-level Panel was asked inter alia to study the possibility of using force to address the threats that Annan argued the UN's collective security system failed to deal with. ${ }^{384}$ The Panel proposed the use of military force in circumstances where the threat was primarily internal, "saving lives within countries in situation of mass atrocity.",385

While acknowledging that governments bear the primary responsibility to protect their people, the Panel endorsed "a collective international responsibility" for the wider international community to take up if governments are unable or

\footnotetext{
${ }^{381}$ Ibid., 16.

${ }^{382}$ Ibid., 23.

383 "A more Secure World: Our Shared Responsibility," the United Nations, December 1, 2004, A/59/565, http://www.un.org/secureworld.

${ }^{384}$ The High-level Panel was mandated to assess current threats to international peace and security; to evaluate how existing policies and institutions have done in addressing those threats; and to make recommendations for strengthening the United Nations so that it can provide collective security for all in the twenty -first century.

385 “A more Secure World: Our Shared Responsibility,” paragraph 199.
} 
unwilling to do so. ${ }^{386}$ Further, in order for the international community to exercise such collective responsibility, the Panel was of the view that, under the Security Council's authority, military intervention should be allowed as a last resort. The scope of military intervention was restricted to genocide, other large-scale killings, ethnic cleansing or serious violations of international humanitarian law. In addition, coercive actions had to meet the threshold criteria, including seriousness of the threat, proper purpose, last resort, proportional means and balance of consequences. $^{387}$

Former Secretary-General Kofi Annan in his report In Larger Freedom: Towards Development, Security and Human Rights for All, released in March 2005 , endorsed the collective responsibility to protect and proposed that the Security Council should use a wide range of methods, including enforcement action, to exercise such responsibility. ${ }^{388}$ Following up the Panel's recommendations, Annan called for a new consensus on the interpretation of Article 51 of the UN Charter so as to cover not only attacks that have already happened but also imminent and latent threats to international peace and security. ${ }^{389}$ In his view, crimes such as genocide, ethnic cleansing or crimes against humanity were latent threats to international peace and security and should therefore fall under the purview of the Security Council. He urged the Security Council to adopt a resolution setting out principles for the use of military force

\footnotetext{
${ }^{386}$ Ibid., paragraph 203.

${ }^{387}$ Ibid., paragraph 201.

388 "In Larger Freedom: Towards Development, Security and Human Rights for All," the United Nations, March 21, 2005, A/59/2005, http://www.un.org/largerfreedom. Paragraph 135 reads: “...I believe that we must embrace the responsibility to protect, and, when necessary, we must act on it. This responsibility lies, first and foremost, with each individual State, whose primary raison d'être and duty is to protect its population. But if national authorities are unable or unwilling to protect their citizens, then the responsibility shifts to the international community to use diplomatic, humanitarian and other methods to help protect the human rights and well-being of civilian populations. When such methods appear insufficient, the Security Council may out of necessity decide to take action under the Charter of the United Nations, including enforcement action, if so required. In this case, as in others, it should follow the principles set out in section III above."

${ }^{389}$ Ibid., paragraphs 122-126.
} 
"not only to preserve international security and peace in general but also in responding to genocide, ethnic cleansing and others such as crimes against humanity arguably threats to international peace and security.",390

Before the release of these two reports, RtoP was a completely new idea to the Vietnamese diplomats at the UN. ${ }^{391}$ In the General Assembly debate on the Secretary-General's report in April 2005, the Vietnamese representative treated the use of force and RtoP as if they were two separate issues. He opposed the attempts to reinterpret Article 51, arguing that it would provide states with an expanded scope to take military action, particularly in response to a perceived imminent threat. ${ }^{392}$ In this respect Vietnamese concerns had been stoked by the invasion of Iraq in $2003 .{ }^{393} \mathrm{He}$ also told the debate that Vietnam did not endorse responsibility to protect as an emerging norm of international law. ${ }^{394}$ This official later confirmed in the interview that he believed "the rationale behind the West's push forward RtoP, in addition to human protection purposes, was to interfere into internal affairs of other states." 395 He said, given the fact that RtoP was an issue pressed by the Secretary-General, Vietnam watched the process closely. However its participation in RtoP deliberations in 2005 was modest.

At the World Summit held in New York in September 2005, RtoP was reportedly one of the few substantive items to survive the negotiations. It was

\footnotetext{
${ }^{390}$ Ibid., paragraph 125.

${ }^{391}$ Interview by author in Hanoi, December 30, 2011.

392 "The $90^{\text {th }}$ Plenary meeting of the General Assembly," the United Nations, April 8, 2005, http://daccess-dds-ny.un.org/doc/UNDOC/GEN/N05/301/15/PDF/N0530115.pdf?OpenElement. ${ }^{393}$ Internal debates revealed that among some quarters there was the fear that Vietnam would be the next target after the Iraq War in 2003. This fear was reflected in the Resolution of the 8th Plenum of the Party Central Committee (IXth tenure) on the Strategic Orientations of National Defence in the New Situation (2003).

394 "The 90th Plenary meeting of the General Assembly," the United Nations, April 8, 2005, http://daccess-dds-ny.un.org/doc/UNDOC/GEN/N05/301/15/PDF/N0530115.pdf?OpenElement. ${ }^{395}$ Interview by author in Hanoi, February 10, 2012.
} 
mentioned in three paragraphs $\left(138,139\right.$, and 140) of the Outcome Document. ${ }^{396}$ First, it is provided that the responsibility to protect lies first and foremost with individual states and their responsibility is "to protect its population from genocide, war crimes, ethnic cleansing and crimes against humanity." 397 Second, the international community has a responsibility to assist states to fulfil their responsibilities. And third, in case governments manifestly fail to protect their people and that peaceful means prove inadequate, the international community should take collective action, in a timely and decisive manner, to protect the population at risk. ${ }^{398}$

There are two important differences between RtoP as provided in the Outcome Document and that initially proposed in the ICISS' report. First, while the ICISS's report proposed a wide scope of RtoP application, ${ }^{399}$ the post 2005 concept restricted its application only to the four worst crimes, namely genocide, ethnic cleansing, war crimes and crimes against humanity. Second, the Outcome Document acknowledges the special role of the Security Council in exercising collective international responsibility. It is the only body that can sanction the use of pillar three measures, especially force. This was a major shift from the ICISS report, which sought to find a way to act even when the Security Council was deadlocked. ${ }^{400}$

At the World Summit, Vietnamese Foreign Minister Nguyen Dy Nien expressed his support for the Secretary-General's views in his report In Larger

\footnotetext{
396 "World Summit Outcome Document," the United Nations, September 2005, A/60/1, http://www.un.org/summit2005/documents.html.

${ }^{397}$ Ibid., Paragraph 138.

${ }^{398}$ Ibid., Paragraph 139. Since the adoption of the WSOD, RtoP has been included in a number of the Council's resolutions such as the Resolution 1674 and invoked for international action in several circumstances. It is widely agreed that debates about RtoP now focus on its operationalization rather than on it as a concept or norm.

${ }^{399}$ In the ICISS's report RtoP was proposed to apply to internal war, insurgency, repression, or state failure where a population was suffering serious harm, or in other conscience-shocking situations where large scale loss of human life or ethnic cleansing occurred.

400 "The Responsibility to Protect," pp. 53-56.
} 
Freedom and the commitments contained in the World Summit Outcome Document. ${ }^{401}$ Notably, he mentioned RtoP in relation to human rights protection and called for "more in-depth discussion" if the concept was to have broader support. This subtle shift evinced a more positive attitude toward the new concept. In 2006-2007, Vietnamese officials at the UN started using the language of responsibility to protect. In November 2007, the Vietnamese representative Le Luong Minh told a Council meeting on the protection of civilians in armed conflict, that "states bear the primary responsibility within their jurisdiction for the protection of their own populations. ${ }^{402}$ As a non-permanent member of the UNSC in 2008-2009, Vietnam became increasingly engaged with RtoP. Support for the concept was reaffirmed in various statements. As Bellamy and Davies observe, Vietnam's position shifted from opposition to positive engagement in a short period of time. Prior to the 2005 World Summit, Vietnam opposed RtoP; in 2005-2007, the country was described as one of a group of "fence-sitters" and then became "RtoP-engaged" in 2008-2009. ${ }^{403}$ While this simple typology usefully captures the change in Vietnam's position, how Vietnam came to endorse RtoP needs a closer look, especially the period that relates to debates about the implementation of RtoP.

In January 2009, Secretary-General Ban Ki-moon released a major report on implementing RtoP. The report broke down RtoP into three pillars: (i) the state's own responsibility to protect all peoples on its territory; (ii) international assistance to help build a state's capacity to deliberate on its responsibility; and

\footnotetext{
401 "Statement by H.E. Mr Nguyen Dy Nien, Minister of Foreign Affairs of the Socialist Republic of Vietnam to the $60^{\text {th }}$ session of the United Nations General Assembly," the United Nations, September, 21, 2005, http://www.un.org/webcast/ga/60/statements/viet050921eng.pdf.

402 "Security Council Meeting on Protection of Civilians in Armed Conflict," the United Nations, November 20, 2007, http://www.un.org/en/ga/search/view_doc.asp?symbol=S/PV.5781(Resumption1).

${ }^{403}$ Bellamy and Davies, "The Responsibility to Protect in the Asia-Pacific Region."
} 
(iii) the international responsibility to protect. ${ }^{404}$ Vietnam's position on RtoP was fully elaborated for the first time in a subsequent debate on the report. ${ }^{405}$ Speaking to the General Assembly, Ambassador Bui The Giang reaffirmed Vietnam's endorsement of RtoP, particularly the first pillar. Reservations remained, however, with respect to some aspects of the second and the third pillars. For example, in the Vietnamese perspective, international assistance should be provided in a manner so that it would not infringe on states' sovereignty. Timely and decisive collective action should not be interpreted as confined to coercive military action. ${ }^{406}$ Fear that RtoP might be abused to justify intervention in states' internal affairs was also raised. ${ }^{407}$

\section{On the first pillar}

Vietnam totally endorses the first pillar of RtoP. This position was reiterated in various statements in 2008-2009 that states bear the primary responsibility for the protection of civilians. The Security Council's debates relating to RtoP cover primarily the issue of protection of civilians in armed conflict, particularly women and children as the most vulnerable groups. Having struggled with prolonged wars, Vietnam strongly endorsed support for these two groups. On various occasions, Vietnamese officials expressed their deep concern with the worsening situations, particularly in many African states, where an increased number of women and children were falling victim to killing, sexual

\footnotetext{
404 "Report of the Secretary-General on Implementing the Responsibility to Protect," the United Nations, January 12, 2009, A/63/677, http://www.un.org/en/ga/search/view_doc.asp?symbol=A/63/677.

405 "Statement by H.E. Ambassador Bui The Giang, Deputy Permanent Representative of Viet Nam, at the General Assembly Plenary Meeting on Responsibility to Protect (R2P)," Permanent Mission of the Socialist Republic of Vietnam to the United Nations, July 24, 2009, http://www.vietnam-un.org/en/vnun.php?id=151\&cid=23.

${ }^{406}$ Ibid.

${ }^{407}$ Nguyễn Nhâm, "Lạm dụng trách nhiệm bảo vệ: Lợi bất cập hại” [Abuse of the Responsibility to Protect and Its Implications] Báo Điện tử Đảng Cộng sản Việt Nam, June 22, 2011, http://dangcongsan.vn/cpv/Modules/News_English/News_Detail_E.aspx?CN_ID=465218\&CO_I $\mathrm{D}=30671 \mathrm{http}: / /$ www.cpv.org.vn/cpv/modules/news/newsdetail.aspx?cn_id=465218\&co_id=30127 \#.
} 
violence, maiming, abuse, humiliation and inhumane treatment. ${ }^{408}$ They also believed that Vietnam's own remarkable achievements in the protection of women and children during the process of national reconstruction and development, meant it could share its experiences and make a tangible contribution to the cause at the global level.

As President of the Security Council in July 2008, Vietnam initiated an open debate on the protection of children in armed conflict. Foreign Minister Pham Gia Khiem told the debate that "Vietnam is committed to defending and promoting the best interests of children in every circumstance and our concerns for children affected by armed conflict are beyond conventional reasoning." 409 The debate ended with the issuance of a statement by the President of the Security Council in which Vietnam on behalf of the Council reiterated its commitment to address the widespread impact of armed conflict on children and its determination to ensure respect for and implementation of all resolutions on this issue. ${ }^{410}$ In October 2009, Vietnam (again in the presidency) took the initiative to organize an open debate on women, peace and security. Pham Gia Khiem shared experiences about the protection and empowerment of women in the country's reconstruction process, stressing the critical role of the state and society in making comprehensive efforts to provide basic needs for people. ${ }^{411}$ The debate resulted in the adoption of Resolution 1889 on women, peace and security - the first

408 "Security Council Open Debate on Children and Armed Conflict," February 12, 2008;

"Security Council Debate on Peace and Security in Africa," April 16, 2008; "Security Council Open Debate on Protection of Civilians in Armed Conflict," May 27, 2008; "Security Council Debate on Women, Peace and Security: Sexual Violence in Situations of Armed Conflict," June 19, 2008;

409 "Statement by H.E Mr. Pham Gia Khiem, Deputy Prime Minister and Minister of Foreign Affairs at the United Nations Security Council Open Debate on Children and Armed Conflict," Permanent Mission of the Socialist Republic of Vietnam to the United Nations, July 17, 2008, http://www.vietnam-un.org.

410 "Statement by the President of the Security Council," the United Nations, July 17, 2008. S/PRST/2008/28, http://www.un.org/ga/search/view_doc.asp?symbol=S/PRST/2008/28.

411 "Address by H.E. Pham Gia Khiem, Deputy Prime Minister and Minister of Foreign Affairs at the Open Debate of the UN Security Council on Women and Peace and Security," Permanent Mission of the Socialist Republic of Vietnam to the United Nations, October 5, 2009, http://www.vietnam-un.org/en/vnun.php?id=158\&cid=1. 
resolution that Vietnam had successfully led in thirty years of participation in the $\mathrm{UN}^{412}$

In addition, Vietnam consistently pursued a comprehensive preventive strategy on RtoP. Pham Gia Khiem told the Council meeting on children in armed conflict in July 2008 that:

Vietnam attaches great importance to a preventive strategy, one that has a dual objective of preventing armed conflict in the first place by addressing its root cause and preventing children from being affected by armed conflict. Such a comprehensive prevention approach must include promoting sustainable development, poverty eradication, national reconciliation, good governance, democracy, the rule of law and respect for and protection of human rights and reintegration and rehabilitation of children associated with armed forces and armed groups. ${ }^{413}$

Vietnamese Deputy Permanent Representative Bui The Giang at the debate on Ban Ki-moon's report on RtoP implementation in July 2009 reaffirmed the country's comprehensive and preventive approach to RtoP, saying that "the best way to protect the population is to prevent wars and conflicts and to address the root causes of conflicts and social tensions, which lie in poverty and economic underdevelopment." ${ }^{414}$ The process of addressing the root causes of conflicts, in the Vietnamese perspective, requires the UN's contribution as the world's largest pool of experience and expertise. Vietnam therefore supports the role of the international community through the $\mathrm{UN}$ in assisting states in need as reflected in the second pillar of RtoP. ${ }^{415}$

412 "Security Council Resolution 1889," the United Nations, October 5, 2009, http://www.un.org/ga/search/view_doc.asp?symbol=S/RES/1889(2009).

413 "Statement by H.E Mr. Pham Gia Khiem, Deputy Prime Minister and Minister of Foreign Affairs at the United Nation Security Council Open Debate on Children and Armed Conflict," Permanent Mission of the Socialist Republic of Vietnam to the United Nations, July 17, 2008, http://www.vietnam-un.org.

414 "Statement by H.E. Ambassador Bui The Giang, Deputy Permanent Representative of Viet Nam, at the General Assembly Plenary Meeting on Responsibility to Protect (R2P)," Permanent Mission of the Socialist Republic of Vietnam to the United Nations, July 24, 2009, http://www.vietnam-un.org/en/vnun.php?id=151\&cid=23. ${ }^{415}$ Ibid. 


\section{On the second pillar}

Vietnam endorses the second pillar of RtoP, namely that "the international community should, as appropriate, encourage and help states to exercise their responsibility." ${ }^{, 46}$ Vietnam supports international assistance mainly in the form of capacity building. Addressing a Council meeting on the protection of civilians in May 2008, the Vietnamese representative recommended the United Nations help improve national capacity by providing technical assistance and conducting awareness-raising activities, for instance through training courses. ${ }^{417}$

Vietnam's primary concern with the second pillar of RtoP was how to make international assistance effective and sustainable. Specifically, Vietnamese representatives expressed concern about the potential infringements on sovereignty if the international community was going to provide assistance to concerned governments. They argued that international assistance in whatever form must be provided in a manner that respects states' independence, sovereignty, and territorial integrity. Officials highlighted a number of circumstances in which infringements of states' sovereignty could occur. For example, it might involve the creation of international mechanisms in order to help a state improve its national capacity. On this issue, Vietnam's position was articulated as follows:

[we hold that] the creation and application of any international mechanism should be thoroughly studied with a view to ensuring its efficient, effective and sustainable performance without resulting in an unnecessary financial burden for States, and that such act should respect national sovereignty, territorial integrity, ownership and self-determination and should be in accordance with the United Nations Charter and international law. ${ }^{418}$

\footnotetext{
416 “The World Summit Outcome Document," paragraph 38.

417 "Statement by H.E. Ambassador Mr. Bui The Giang, Deputy Permanent Representative at Security Council Open Debate on Protection of Civilians in Armed Conflict," Permanent Mission of the Socialist Republic of Vietnam to the United Nations, May 27, 2008, http://www.vietnamun.org/en/vnun.php?id=67\&cid=1.

${ }^{418}$ Ibid.
} 
Second, when the situation in a given state is referred to international criminal courts or similar mechanisms, Vietnam recommended that such reference should only be considered on a case-by-case basis to avoid the risk of infringing on state sovereignty. ${ }^{419}$ A third potential infringement on states' sovereignty might involve humanitarian access during a conflict situation. At a Council debate on the protection of civilians in armed conflict in May 2008, Vietnam's representative Bui The Giang stressed that "humanitarian access and assistance should be independent of political and military measures, and in keeping with the principle of humanity, neutrality, impartiality and independence, and in conformity with national and international law."420

The concern about possible infringement of sovereignty came up in the context of the humanitarian crisis caused by Cyclone Nargis in Myanmar in May 2008. In response to slow progress on the part of the Myanmar government in facilitating international relief efforts, French Foreign Minister Bernard Kouchner called for the UN Security Council to invoke RtoP and issue a resolution authorizing the delivery of aid to Myanmar people, even without Myanmar's consent. ${ }^{421}$ At the same time, France and the United Kingdom (UK) called on the Council to discuss humanitarian assistance for Myanmar. ${ }^{422}$

\footnotetext{
419 “Statement by H.E Ambassador Bui The Giang at the Security Council's Debate on Protection of Civilians in Armed Conflict," Permanent Mission of the Socialist Republic of Vietnam to the United Nations, June 26, 2009, http://www.vietnam-un.org/en/vnun.php?id=145\&cid=1.

420 "Statement by H.E. Ambassador Mr. Bui The Giang, Deputy Permanent Representative at Security Council Open Debate on Protection of Civilians in Armed Conflict," Permanent Mission of the Socialist Republic of Vietnam to the United Nations, May 27, 2008, http://www.vietnamun.org/en/vnun.php?id=67\&cid=1.

${ }^{421}$ See Andrew Selth, "Even Paranoids Have Enemies: Cyclone Nargis and Myanmar's Fears of Invasion," Contemporary Southeast Asia 30, no. 3 (2008): 397-402; Alex J. Bellamy, "The Responsibility to Protect: Five Years On," Ethics and International Affairs 24, no. 2 (2010):14369; Tin Maung Maung Than, "Myanmar in 2008: Weathering the Storm," Southeast Asian Affairs (2009): 195-222.

${ }^{422}$ MOFA Department of International Organizations Report, "On the UNSC's activities and Vietnam's Participation in April 2008," no. 554/BC-BNG-TCQT, dated May 21, 2008, p.1.
} 
Vietnamese officials saw the proposal by France, the UK and other Western countries as an attempt to politicize the issue of humanitarian aid for Myanmar, as part of their pressure on the military government over its human rights record. ${ }^{423}$ Vietnam and other ASEAN members preferred that ASEAN would play the leading role in helping Myanmar address the consequences of the Cyclone. ${ }^{424}$ A senior Vietnamese official said in the interview that in a private meeting between the UN Secretary-General and ASEAN representatives on this issue, Vietnam, while acknowledging assistance was needed, expressed concern about a possible intervention in Myanmar on humanitarian grounds. He believed that "ASEAN alone could help, if Myanmar requested, and therefore there was no need for assistance or intervention from outside ASEAN." 425

At the Council, in coordination with the Chinese, Russian and Indonesians, Vietnamese officials argued that a natural disaster was not an issue of international peace and security and therefore was not under the purview of the UNSC. Collectively they opposed holding a separate meeting on the issue and indirectly rejected the French proposal to invoke RtoP, ${ }^{426}$ so as to lessen pressure

\footnotetext{
${ }^{423}$ MOFA Department of International Organizations Report, "On the UNSC's activities and Vietnam's Participation in May 2008," no. 673/BC-BNG-TCQT, dated June 10, 2008, p.5.

${ }^{424}$ Ibid.

${ }^{425}$ Interview by author in Hanoi, March 27, 2013. This official said Vietnam initially wanted to sponsor an international conference on humanitarian assistance for Myanmar, however, as it was reported, the Mission in New York did not receive instruction from Hanoi on the proposal. A conference was then organized by ASEAN and the UN through the UN Office in Bangkok, Thailand.

${ }^{426}$ The Council did not discuss humanitarian access following Cyclone Nargis in Myanmar in a separate meeting given that natural disaster was not under the purview of the Security Council. Rather, the issue was raised again among others at a Council debate on protection of civilians in armed conflict on May 27, 2008 at which Under Secretary-General for Humanitarian Affairs and Emergency Relief Coordinator John Homes called for finding a satisfactory way of dealing with access issues for natural disaster. See, "Security Council Open Debate on Protection of Civilians in Armed Conflict, the United Nations, May 27, 2008,

“ http://www.un.org/en/ga/search/view_doc.asp?symbol=S/PV.5898.
} 
on Myanmar. ${ }^{427}$ ASEAN and the UN then facilitated a conference on relief efforts and reconstruction for Myanmar. ${ }^{428}$

In the case of Myanmar, Vietnam feared the Council's mandate might be expanded to include natural disasters, thus creating more opportunities for its powerful members to intervene in others' internal affairs - a trend that Vietnam wanted to prevent. ${ }^{429}$ If France had been successful in seeking the Council's authorization of aid delivery without Myanmar's consent, the act would have been seen as an infringement of Myanmar's sovereignty. Vietnam therefore emphasized the consent of the state concerned as a prerequisite when the international community assists states in need. The Vietnamese representative told the debate on Ban Ki-moon's report that "international assistance can be most effective if it is based on engagement and cooperation with related states." ${ }^{430}$ In short, the voice of governments must be heard and their sovereignty respected when the international community exercises its responsibility to help states concerned.

\section{On the third pillar}

While endorsing the third pillar, Vietnam remains cautious on the socalled "timely and decisive collective action" that may be taken by the international community to exercise the responsibility to protect. The Vietnamese representative also told the General Assembly's plenary meeting on RtoP in July 2009 that the concept of "collective action" should be further clarified so that it

\footnotetext{
${ }^{427}$ MOFA Department of International Organizations Report, "On the UNSC's activities and Vietnam's Participation in May 2008," no. 673/BC-BNG-TCQT, dated June 10, 2008, p.5.

428 "ASEAN-UN International Pledging Conference on Cyclone Nargis," ASEAN, May 25, 2008, http://www.aseansec.org/21569.htm.

${ }^{429}$ MOFA Department of International Organizations Memo, "On the Council's Procedural Voting on the format of the Meeting on Zimbabwe," no. D 198/08, dated June 23, 2008, p. 2.

430 "Statement by H.E. Ambassador Bui The Giang, Deputy Permanent Representative of Viet Nam, at the General Assembly's Plenary Meeting on Responsibility to Protect (R2P)," Permanent Mission of the Socialist Republic of Vietnam to the United Nations, July 24, 2009, http://www.vietnam-un.org/en/vnun.php?id=151\&cid=23.
} 
would not be interpreted as solely confined to coercive military action. ${ }^{431} \mathrm{He}$ reemphasized the need to have consent of state concerned and its voluntary engagement should timely and decisive collective action be taken by the international community to protect civilians from the four prescribed crimes. Furthermore, the application of other measures proposed in the SecretaryGeneral's report - such as economic sanctions and reference to the International Criminal Court - should be on a case-by-case basis, free from politicization, selectivity and double standards. These concerns reflect Vietnam's continued preference for upholding the principle of non-interference through preventing or limiting the application of intervention measures. ${ }^{432}$

Vietnam's concern about the application of the third pillar was most apparent in the case of Zimbabwe. According to a Vietnamese official, Zimbabwe was a case where a majority of the Security Council's members strongly urged for intervention by invoking RtoP. ${ }^{433}$ A violent political crisis broke out in Zimbabwe during the 2008 presidential election in which the government of President Robert Mugabe was alleged to have targeted political opponents and committed serious human rights violations. ${ }^{434}$ Briefing the Security Council in June, Under Secretary-General Lynn Pascoe said the situation in Zimbabwe had deteriorated to alarming levels. ${ }^{435}$ The Zimbabwean government was warned that it had the primary responsibility to ensure the security for all citizens, had to create conditions for free and fair elections, stop violence and intimidation and bring those responsible to justice. ${ }^{436}$ In another briefing at the Council, Deputy Secretary-General Asha-Rose Migoro again warned that "it is the urgent

\footnotetext{
431 Ibid.

${ }^{432}$ MOFA Department of International Organizations Memo "On the Procedural Voting on the form of meeting on Zimbabwe," no. D198, dated June 23, 2008, p.2.

${ }^{433}$ Interview by author in Hanoi, December 30, 2011.

434 "Crisis in Zimbabwe," the Global Responsibility to Protect, accessed October 12, 2012 http://www.responsibilitytoprotect.org.

435 "Security Council meeting on Peace and Security in Africa," the United Nations, June 23, 2008, http://www.un.org/en/ga/search/view_doc.asp?symbol=S/PV.5919

${ }^{436}$ Ibid.
} 
responsibility of the Government of Zimbabwe to protect its citizens and to cease immediately all forms of violence." ${ }^{437}$ The Deputy Secretary-General also added that those who perpetrated crimes must be held to account and the victims of violence deserved justice.

Despite these warnings and regional efforts at mediating the crisis, the situation in Zimbabwe continued to worsen. The Security Council was then obliged to take collective action in order to prevent the situation from further deteriorating. A majority of the Council's members supported open debate on Zimbabwe. The United States, the UK and Italy proposed making the situation in Zimbabwe a regular item on the agenda. ${ }^{438}$ In June 2008, the President of the Security Council issued a statement condemning the campaign of violence intentionally carried out by the Zimbabwean government which had resulted in the killings, beating and displacement of thousands of people, denying the right of political opponents to campaign freely and suspension of the operations of humanitarian organizations. ${ }^{439}$

At the same time, the United States, with support from a group of UN members, ${ }^{440}$ drafted a resolution on Zimbabwe. The message conveyed in the draft resolution was that there were serious and widespread violations of human rights in Zimbabwe and that the Zimbabwean government had failed to fulfil its responsibility to protect. By ignoring the warnings and refusing assistance from the international community, the Zimbabwean government had become the persecutor instead of the protector of its people. The US draft resolution outlined

\footnotetext{
437 "Security Council's meeting on Peace and Security in Africa," the United Nations, July 8, 2008, http://www.un.org/en/ga/search/view_doc.asp?symbol=S/PV.5929.

${ }^{438}$ MOFA Department of International Organizations Memo "On the Procedural Voting on the form of meeting on Zimbabwe," no. D198, dated June 23, 2008.

439 "Statement by the President of the Security Council," the United Nations, June 23, 2008, http://www.un.org/News/Press/docs/2008/sc9369.doc.htm.

${ }^{440}$ This group included Australia, Belgium, Canada, Croatia, France, Italy, Liberia, Netherlands, New Zealand, Sierra Leone, and the United Kingdom of Great Britain and Northern Ireland.
} 
various measures as provided for in the Chapter VII of the UN Charter, including travel restrictions targeting a number of Zimbabwean officials, an arms embargo, and a freeze on financial assets. ${ }^{441}$ It also called for the appointment of an UN special envoy to Zimbabwe and for provision of humanitarian assistance.

Security Council members then discussed the draft resolution at their meeting on Peace and Security in Africa on July 11, 2008. ${ }^{42}$ Speaking in favour of the draft resolution, UK representative Sir John Sawers argued that the Zimbabwe situation constituted a grave humanitarian crisis for which the government of Zimbabwe bore full responsibility, pointing out that Mugabe's government had ignored appeals to lift restrictions on humanitarian supplies. The representative from Costa Rica supported the inclusion in the draft solution of language concerning the need to fix responsibility for human rights abuses. Explaining France's support for the draft resolution, the French representative said that, in addition to political dialogue, pressure is also necessary in order to protect the people and to hold accountable those who are blocking the current political process. He also told the Council that the European Union was considering intensifying the sanctions it already had in place. Croatia's representative supported the proposed measures and argued that the Council's action - the draft resolution - was timely and long awaited.

The draft resolution, however, did not receive support from China, Russia, South Africa, Libya or Vietnam. The Vietnamese permanent representative Le Luong Minh said Vietnam could not support it, arguing that the situation in Zimbabwe did not constitute a threat to regional or international peace and security and therefore it was not within the mandated purview of the Security Council. In addition, he said the proposed sanctions, if applied, "would set a

441 "Draft Resolution on Zimbabwe," the United Nations, July 11, 2008, http://www.un.org/en/ga/search/view_doc.asp?symbol=S/2008/447.

442 "Security Council Meeting on Peace and Security in Africa," the United Nations, July 11, 2008, http://www.un.org/en/ga/search/view_doc.asp?symbol=S/PV.5933. 
dangerous precedent for intervention in the internal affairs of sovereign states and would run counter to the fundamental principles of international law and the Charter of the United Nations.",443

MOFA internal documents reveal that Vietnam did not want the situation in Zimbabwe to be politicized and further complicated. Therefore, in response to the proposal by the majority of the Council to hold an open debate on the situation in Zimbabwe, Vietnam, (together with China, Russia, South Africa, Indonesia and Libya) proposed a closed meeting. ${ }^{444}$ Vietnamese officials also believed the US draft was ill-intentioned and contained strong intervention measures. ${ }^{445}$ In an exchange of views with Chinese diplomats in Hanoi, Vietnamese officials agreed with the Chinese position that the Security Council ought to be cautious on the issue and opposed the application of sanctions on Zimbabwe. ${ }^{446}$ It was also revealed that in their informal discussions representatives from China, South Africa, Libya, Indonesia and Vietnam had mentioned the possibility of accepting a Security Council resolution on Zimbabwe on the condition that all "sensitive issues" were removed. ${ }^{447}$ Vietnam's position on the draft resolution on Zimbabwe was then summed up as follows:

We do not have direct interests in the case of Zimbabwe, albeit our strong relationship with the Zimbabwe African National Union (ZANU) led by Mugabe before ZANU took the power in 1980. However, we should uphold the principle of non-interference in internal affairs of states, avoiding the creation of precedents for Western countries through the Security Council to interfere in states' internal affairs in response to the complicated situations involving elections in a number of developing

\footnotetext{
443 Ibid.

${ }^{444}$ MOFA Department of International Organizations Memo "Our Position on the Security Council's draft resolution on Zimbabwe," dated July 23, 2008, p. 2.

445 Ibid. p. 1.

${ }^{446}$ MOFA Department of International Organizations Report "On the exchange of views with Chinese Second Secretary," dated July 4, 2008.

${ }^{447}$ MOFA Department of International Organizations Memo "Our Position on the Security Council's draft resolution on Zimbabwe," dated July 8, 2008, p. 1.
} 
countries and members of the Non-Aligned Movement, including those in Southeast Asia and our neighbouring countries. ${ }^{448}$

In the event that the draft resolution was put to the vote, Vietnam should follow the scenarios below:

Scenario 1: We would abstain if China and Russia veto (or one of the two vetoes) and non-aligned members agree with our position to abstain.

Scenario 2: If China and Russia (or one of the two) and one non-aligned member vote against, we would do the same. ${ }^{449}$

The Zimbabwe case shows that Vietnam still had concerns about intervention and sought to prevent the Council from acting on behalf of the international community and using RtoP to the interfere in internal affairs of states. Vietnam and the other reluctant Council members were successful. China and Russia exercised their vetoes and the draft resolution on Zimbabwe was not adopted. $^{450}$

\section{An increased comfort level with RtoP}

While Vietnam still had reservations, as was evident in the cases of Myanmar and Zimbabwe, it was generally becoming more supportive of RtoP. Indeed, in July 2009 Deputy Permanent Representative Bui The Giang said with confidence that "we now do not have to discuss whether R2P is necessary... and we do not have to struggle to define the scope of this concept." ${ }^{451}$ In comparison with statements delivered in 2004-2005, the language of this statement reflected an increased comfort level toward RtoP among Vietnamese officials in New York.

\footnotetext{
${ }^{448}$ MOFA Department of International Organizations Memo "Our Position on the Security Council's draft resolution on Zimbabwe," dated July 10, 2008, p. 4

${ }^{449}$ Ibid.

${ }^{450}$ The result of the Council's vote was nine in favour (Belgium, Burkina Faso, Costa Rica, Croatia, France, Italy, Panama, the United Kingdom, and the United States), five against (China, Libya, Russian Federation, South Africa, and Vietnam) and one abstained (Indonesia).

451 "Statement by H.E. Ambassador Bui The Giang, Deputy Permanent Representative of Viet Nam, at the General Assembly Plenary Meeting on Responsibility to Protect (R2P)," Permanent Mission of the Socialist Republic of Vietnam to the United Nations, July 24, 2009, http://www.vietnam-un.org/en/vnun.php?id=151\&cid=23.
} 
Theory would suggest that this comfort level is evidence of successful persuasion. The following section explores how, through deliberations, Vietnamese diplomats judged the contents of RtoP in order to see if their attitudinal change was a result of persuasion. It also considers two alternative explanations: social influence and mimicking. A social influence explanation argues that Vietnam's decision to endorse RtoP was part of its efforts to realize the social goal of building a good image of Vietnam as a proactive and responsible member in the world community. "Not rocking the boat" also prevented Vietnamese officials from opposing RtoP at a time when majority UN members had endorsed the principle.

Mimicking suggests that novices will copy what others are doing in order to adapt to a new and uncertain environment and they do so without knowing what the costs and benefits are. A mimicking explanation for Vietnam's endorsement of RtoP would be that Vietnamese representatives as novices in the Security Council found that the best way to adapt to the working procedures and environment was to follow others, engaging in the deliberations on RtoP irrespective of the potential costs or benefits.

\section{Persuasion as an explanation}

As Johnston states, an optimal environment for persuasion would have the following features: (i) small membership; (ii) a couple of actors are recognized as authoritative (information they provide is more convincing); (iii) decision making rules are based on consensus; (iv) the institution's mandate is deliberative; and (v) agents enjoy high levels of autonomy from their principals. Johnston argues that for a novice, information from in-groups or from sources that are "liked" is more convincing than that from out-groups or the "disliked." Thus, in an institution with small membership, the effects of social liking and in-group identity will be strongest. In addition, consensus as the decision-making rule and deliberation as mandate are the two institutional features that help facilitate the assessment of 
counter-attitudinal arguments and give actors some degree of free choice when considering the implications of (not) holding to their initial attitudes. Similarly, the higher the degree of independence the actors enjoy in relation to their principals the more likely that actors can be persuaded.

To what extent is the working environment in the UNSC conducive to persuasion against the above criteria? On the surface, two features do not appear to be conducive to persuasion. First, deliberations on RtoP did not take place among a small group of participants. Rather, discussions were conducted at both the General Assembly and the Security Council and involved a wide range of actors. The UNSC meeting on RtoP in December 2008 is one example. Participants attending the meeting were diverse, including representatives from Security Council members and many experts in the field. ${ }^{452}$ The debate in the General Assembly following Ban Ki-moon's report on RtoP implementation in July 2009 lasted for two days with 94 statements from UN members and observers. ${ }^{453}$ In these debates and at other Security Council's deliberations on RtoP - related issues, Vietnam had multiple reference groups: China and Russia as major powers that had been traditionally "like-minded"; ASEAN states both inside and outside the UNSC; non-aligned members and other UN members.

Second, in terms of agent autonomy, Vietnamese representatives in New York did not enjoy much freedom to take positions, given strict reporting obligations, coordinating mechanisms and fixed guiding principles which regulated activities at the UNSC. For example, they had to seek instructions from

\footnotetext{
${ }^{452}$ For the list of participants, see Appendix I, "Letter dated 30 December 2008 from the Permanent Representative of South Africa to the United Nations addressed to the President of the Security Council," S/2008/836, December 31, 2008, http://www.refworld.org/docid/48abd5980.html.

453 "Report on the General Assembly Plenary Debate on the Responsibility to Protect," International Coalition for the Responsibility to Protect, September 15, 2009, http://www.responsibilitytoprotect.org/ICRtoP\%20ReportGeneral_Assembly_Debate_on_the_Responsibility_to_Protect\%20FINAL\%209_22_09.pdf.
} 
and submit periodical reports to Hanoi. These reports - monthly, six-monthly and annually - on Vietnam's operations at the Council went to MOFA's leaders, the Prime Minister and the Politburo. ${ }^{454}$

These features do not match the criteria believed to be conducive to persuasion. In reality, however, these institutional features do not limit persuasion effects. Unlike the negotiations on the ASEAN Human Rights Body and the ARF's deliberations on Preventive Diplomacy, RtoP deliberations at the UN were not so sharply divided that it led to the formation of two opposing groups. Rather, participants came with a shared understanding of the necessity of RtoP and endorsed the concept, although with varying degrees of support. As William R. Pace observed, RtoP was not a "northern or western agenda,"455 on which Western countries sought to impose norms or values on others. RtoP supporters included many states in the developing world and in the Non-Aligned Movement. ${ }^{456}$ In such a working environment, Vietnamese officials did not have to take sides or find themselves under pressure from one particular group.

In addition, because RtoP was a new concept and Vietnamese officials in New York were the first to engage in RtoP discussions and were in charge of dealing with RtoP - related issues, they had an advantage over their colleagues in Hanoi when it came to making recommendations on building a national position on the topic. They had first hand experience of RtoP issues and debates. One official confirmed in an interview that recommendations about RtoP from New York "were always accepted." ${ }^{457}$ Put differently, while routine reporting was

\footnotetext{
${ }^{454}$ MOFA Department of International Organizations Research Project "On the Role of the UNSC and Vietnam's Future Participation," (2005), p. 98.

${ }^{455}$ William R. Pace is Executive Director of the World Federalist Movement's Institute for Global Policy. He was a presenter at the meeting on RtoP organized by South Africa, December 1, 2008. ${ }^{456}$ NAM members accepted RtoP in principle, see "Statement by H.E. Ambassador Maged A. Abdelaziz, Permanent Representative of Egypt on behalf of the Non-Aligned Movement on report of the Secretary-General," The International Coalition for the Responsibility to Protect, July 23, 2009, http://responsibilitytoprotect.org/NAM_Egypt_ENG(1).pdf.

${ }^{457}$ Interview by author in Hanoi, April 8, 2013.
} 
required, Vietnamese officials in New York actually played the key role in planning how Vietnam should operate at the Council and what it should say on the issues debated.

Furthermore, the goal of the discussions was to reach consensus on RtoP as a concept and its future implementation. For example, the purpose of the Council's meeting on RtoP in December 2008 was to build a common understanding of the issues set out in paragraphs 138 and 139 of the WSOD, particularly to remove some of the misunderstandings surrounding the concept, so as to make a contribution to the debate on the Secretary-General's report on RtoP implementation. ${ }^{458}$ In this meeting, RtoP advocates persuaded those who harboured reservations to provide more support for the concept by presenting their arguments for RtoP and conveying the overall message of RtoP in a way that made the concept seem less threatening. For instance, they stressed the nonmilitary aspects of RtoP. Ban Ki-moon's report was also presented in that way, stressing the preventive aspect of RtoP. For Vietnamese officials who were unfamiliar with RtoP, these meetings provided them with a chance to listen to diverse perspectives with some degree of free choice, thus facilitating a better understanding of the concept.

\section{Attitudinal change as result of discussions on RtoP}

One Vietnamese official admitted in an interview that initially he saw "RtoP as humanitarian intervention in disguise." 459 Another believed that "the real motive of some Western governments when intervening was to assist opposition movements inside states they disliked in order to achieve regime change.” Generally, in the Vietnamese perspective, humanitarian intervention was often

\footnotetext{
${ }^{458}$ Appendix I, "Letter dated 30 December 2008 from the Permanent Representative of South Africa to the United Nations addressed to the President of the Security Council," S/2008/836, December 31, 2008, http://www.refworld.org/docid/48abd5980.html.

${ }^{459}$ Interview by author in Hanoi, December 30, 2011.

${ }^{460}$ Interview by author in Hanoi, February 10, 2012.
} 
invoked by an individual or group of states and used to intervene in other states' affairs. ${ }^{461}$ The 2003 US military intervention in Iraq was often cited as the most recent case. ${ }^{462}$ As such, humanitarian intervention has no basis in international law and its application constitutes an infringement on state sovereignty, thus giving major powers more opportunities to impose their values and norms on others. $^{463}$ Vietnamese representatives were therefore concerned about the motivations behind calls for the protection of civilians on RtoP grounds.

However, Vietnamese officials in New York gradually came to have a better understanding of the concept. The senior official who initially saw RtoP as humanitarian intervention in disguise admitted in the same interview that participating in the meeting on RtoP organized by South Africa in December 2008 "had caused a change in his perception of the concept because the distinction between RtoP and humanitarian intervention was clarified." 464 As he understood it, "RtoP did not refer exclusively to military intervention potentially taken by powerful states to intervene in others' internal affairs." Therefore, he no longer saw RtoP as humanitarian intervention in disguise. This official also added that learning more about RtoP helped Vietnamese officials deal more quickly with related issues at the Council.

Another senior official, Nguyen Thi Thanh Ha, had the same observation and came to conclude that "the main difference between RtoP and humanitarian intervention was that collective action on RtoP grounds could only take place within a UN framework, particularly through the Security Council, and had to

\footnotetext{
${ }^{461}$ See Lê Minh, "Về cái gọi là can thiệp nhân đạo" [On the so-called humanitarian intervention], Tạp chí Cọng sản Online, August 28, 2008, http://www.tapchicongsan.org.vn/Home/PrintStory.aspx?distribution=2665\&print=true.

${ }_{462}$ Other US military interventions that Vietnam perceived as humanitarian intervention and which consolidated its fear included those in Grenada, Panama, and Kosovo.

${ }^{463}$ Lê Minh, "Về cái gọi là can thiệp nhân đạo" [On the so-called humanitarian intervention].

${ }^{464}$ Interview by author in Hanoi, December 30, 2011.
} 
adhere to provisions in the UN Charter and in international law."465 In contrast, humanitarian intervention could include actions deployed outside the UN framework and could therefore be used arbitrarily by individual or groups of states for their own purposes. ${ }^{466}$ Contrary to humanitarian intervention, RtoP's objectives, its scope and threshold for implementation were clearly defined and had support from majority of UN members. ${ }^{467}$

In addition to many other meetings and workshops that Vietnamese officials attended, the meeting on RtoP organized by South Africa at the Security Council in December 2008 had an important role in providing Vietnamese officials with a better understanding of RtoP as a concept. ${ }^{468}$ A close reading of the summaries of presentations delivered at this meeting show that the majority of arguments for RtoP were in line with Vietnam's interests. Vietnamese officials also found that other participants had similar concerns relating to RtoP and its future operationalization. Some of the views expressed were as follows: ${ }^{469}$

First, participants stressed the need to distinguish between RtoP and humanitarian intervention. Indeed, almost all presenters stressed the aspects of RtoP that were related to non-military action. A number of participants believed that as a concept RtoP was much broader than humanitarian intervention and the measures to be taken under the name of RtoP were also diverse, not exclusively military intervention. Those advancing the argument included, among others, the

\footnotetext{
${ }^{465}$ Nguyễn Thị Thanh Hà, "Sự khác nhau giữa trách nhiệm bảo vệ và can thiệp nhân đạo" [The differences between the Responsibility to Protect and Humanitarian Intervention], Thế giới và Việt Nam, September 12, 2009, http://www.tgvn.com.vn/printContent.aspx?ID=7476.

${ }^{466}$ Ibid.

${ }^{467}$ Ibid.

${ }^{468}$ This was the only meeting at the Security Council in 2008 devoted to the discussion of RtoP as a concept. A senior official said in the interviews that she had also attended various workshops on RtoP, including those organized by the American Peace Research Institute, to learn more about the concept.

${ }^{469}$ Appendix I, "Letter dated 30 December 2008 from the Permanent Representative of South Africa to the United Nations addressed to the President of the Security Council," accessed September 23, 2012, http://www.refworld.org/docid/48abd5980.html.
} 
South African Permanent Representative Dumisani Kumalo and Edward Luck Special Adviser to the Secretary-General. Kumalo stressed that RtoP encompassed the whole continuum of available measures, not just military intervention. Luck told the meeting that RtoP was to support states rather than undermine them when explaining why the word "intervention" was not used in the 2005 WSOD. An observer from the African Union also underscored the importance of a non-military approach when implementing RtoP. At the same time, a representative of the International Crisis Group (ICG) - a NGO - reassured those critics worried about being the target of an intervention, by saying that RtoP focused on the protection of the affected populations, rather than on the notion of intervention and that military action should only be the last resort. For Vietnam's representatives who had thought of RtoP as humanitarian intervention under a new name, identifying the differences between the two concepts helped remove their fear that the concept only meant military action.

Second, presenters at the meeting primarily took a preventive approach to RtoP. The representative of Burkina Faso stated that RtoP was primarily a responsibility to prevent. Other participants stressed that the priority in RtoP implementation should be given to development, preventing conflict, strengthening national capacities to protect, addressing the root causes of the conflict, such as combating poverty and ending all incitement to violence. As was mentioned above, Vietnam had taken the same approach to RtoP and this position was reflected in various Vietnamese statements in the Security Council in 2008-9.

Third, there were many calls in the meeting for an increased role for the General Assembly and particularly the Secretary-General in the process of RtoP implementation. Edward Luck argued that while the Security Council had a critical role to play in terms of RtoP, it should also interact with other UN organs. He supported an increased role for the General Assembly in prevention, mediation, monitoring and investigation. He added that the Assembly could also 
invoke "Uniting for Peace" if the Council was unable to act. Similarly, the representative of Costa Rica called for the Secretary-General's Special Adviser on the Prevention of Genocide to have a role with regard to early warning and quick response.

Supporting an increased role for the General Assembly was clearly in Vietnam's interests. The country's leadership has repeatedly supported the reforms of the UN, through reinforcing the central role and power of the General Assembly and improving the working methods of the Security Council. ${ }^{470}$ Giving more power to the General Assembly in RtoP implementation, in the Vietnamese perspective, would help counter the trend of the Security Council's expanding mandate, thus giving this exclusive body more opportunity to intervene in states' internal affairs.

Finally, like Vietnam, participants had concerns about the possible abuse of RtoP by powerful states. To address this, Edward Luck called for the development of a clear framework for the implementation of the responsibility to protect in a collective and legal manner. He gave two examples of preventive use of force which had been applied with government consent in the former Yugoslav Republic of Macedonia and Sierra Leone. Luck's emphasis on "legal manner" when implementing RtoP was in line with Vietnam's position that consent or engagement with the state concerned should be sought as precondition for international assistance to be delivered. In response to the proposal for expanding the scope of RtoP to include natural disasters, Luck stressed the importance of keeping the concept focused, rather than stretching it. The mention of natural disaster in the meeting was obviously the result of the previous debates at the Council on the humanitarian crisis in Myanmar when Vietnam and other members

\footnotetext{
470 "Statement by H.E Mr. Nguyen Dy Nien, Minister of Foreign Affairs of the Socialist Republic of Vietnam to the 60th Session of the United Nations General Assembly," the United Nations, September 21, 2005, http://www.un.org/webcast/ga/60/statements/viet050921eng.pdf.
} 
had rejected invoking RtoP for the Council's action. Luck's view therefore helped remove the fear on the part of Vietnamese officials of the possibility that scope of RtoP would be expanded.

In short, clarifying the distinction between RtoP and humanitarian intervention with respect to actions to be taken by the international community helped remove the fear on the part of Vietnamese officials that RtoP measures might be arbitrarily employed. They found the concept less threatening than they had before. More importantly, with emphasis placed on the preventive aspect of RtoP (something which was further elaborated in Ban Ki-moon's report), these officials felt assured that state sovereignty would still be respected, rather than being undermined. This increased comfort level with RtoP was reflected in their public statements. As the Vietnamese representative told the General Assembly's plenary meeting on implementing RtoP in July 2009, there was no need to discuss about whether RtoP was necessary and about its scope. He added that RtoP was now "more imperative and urgent than ever before when conflicts continue to spread and escalate in many parts of the world." ${ }^{471}$ The statement showed just how far Vietnamese officials had come and that they now accepted RtoP as justified.

\section{Attitudinal change as result of involvement in possible RtoP situations}

With about two-thirds of the Security Council's agenda items on Africa, ${ }^{472}$ a representative of Belgium observed that Africa was "the theatre for the

\footnotetext{
471 "Statement by H.E. Ambassador Bui The Giang, Deputy Permanent Representative of Viet Nam, at the General Assembly Plenary Meeting on Responsibility to Protect (R2P)," Permanent Mission of the Socialist Republic of Vietnam to the United Nations, July 24, 2009, http://www.vietnam-un.org/en/vnun.php?id=151\&cid=23.

${ }^{472}$ MOFA Department of International Organizations Research Project "On the Role of the UNSC and Vietnam's Future Participation," (2005), p. 98.
} 
responsibility to protect situations." ${ }^{473}$ However, due to the lack of substantial relationships with African states, Vietnamese officials had a limited knowledge of situations on the continent. ${ }^{474}$ Some Vietnamese diplomats at the UN Mission admitted that for the first several months working at the Council, they did not fully understand situations debated at the Council in general and those in African states in particular. ${ }^{475}$ Subsequent direct involvement in the Council's work helped them learn more about the situation on the ground in the states concerned. For example, Vietnam held the chairmanship of the 1132 Committee on Sierra Leone and vice chairmanship of the Committees on Congo, Lebanon and counterterrorism. This learning process influenced the perception of state representatives on RtoP in both direct and indirect ways.

First, as one diplomat contended, "the situations in a number of African countries could not be resolved without the UN and as a member of the Security Council Vietnam could not ignore or go against the interests of the state concerned." ${ }^{476}$ For instance, on assuming the chairmanship of the 1132 Committee on Sierra Leone in 2008-2009, Vietnamese representatives, together with members of the Special Court for Sierra Leone, travelled to the country and saw evidence of serious human rights violations. ${ }^{477}$ The situation in Southern Sudan, particularly in refugee camps, was also reported to be of great concern and "unimaginable." ${ }^{478}$ Even Kenya - described as the model of development in Africa - was characterized by widespread corruption, ineffective government, and

\footnotetext{
473 Appendix I, "Letter dated 30 December 2008 from the Permanent Representative of South Africa to the United Nations addressed to the President of the Security Council," accessed September, 23, 2012, http://www.refworld.org/docid/48abd5980.html.

${ }^{474}$ Not many Vietnamese embassies have been established in African countries.

${ }^{475}$ Interview by author in Hanoi, December 30, 2011; March 29, 2013.

${ }^{476}$ Interview by author in Hanoi, December 30, 2011.

${ }^{477}$ Interview by author in Hanoi, January 31, 2012.

${ }^{478}$ Ibid. See also "Reports of the Secretary-General on the Sudan," the United Nations, March 20, 2009, http://www.securitycouncilreport.org/atf/cf/\%7B65BFCF9B-6D27-4E9C-8CD3CF6E4FF96FF9\%7D/Sudan\%20S\%20PV\%206096.pdf .
} 
poverty. ${ }^{479}$ Vietnamese officials came to believe that situations in these countries required international intervention in some ways. ${ }^{480}$

Vietnam therefore strongly supported a role for the UN, regional organizations and relevant bodies in helping states prevent conflicts, address their root causes and fulfil their responsibilities under relevant Council's resolutions. ${ }^{481}$ In addition, Vietnam tried to act as a responsible member of the Council, taking into consideration the interests of states concerned. To Vietnamese officials, acting in a responsible manner meant helping to lessen tensions and contribute to the resolution of regional issues "on the basis of principles enshrined in the UN Charter and with consideration of the interests of states concerned."482 For example, as chair of the 1132 Committee, Vietnamese representatives closely worked with the Special Court in Sierra Leone leading to the removal of the majority of individuals subjected to travel restrictions. ${ }^{483}$

Second, from what Vietnamese officials had witnessed in Sierra Leone, Sudan, and Kenya, a reference was made regarding the possible "responsibility to protect situations" in Vietnam. In response to the concern occasionally raised in Hanoi that outsiders could possibly use RtoP as a pretext to intervene in domestic affairs, for example situations relating to ethnic minorities in the Central

\footnotetext{
${ }^{479}$ Interview by author in Hanoi, March 27, 2013.

${ }^{480}$ Interview by author in Hanoi, January 31, 2012.

${ }^{481}$ MOFA Department of International Organizations, Cable message no. 545/HT dated December 27, 2009.

${ }^{482}$ MOFA Department of International Organizations Presentation at the $26^{\text {th }}$ Diplomatic Conference (2008) "Some Initial Thoughts on the Increased Participation in the Process of International Cooperation Toward the Implementation of Vietnamese Foreign Policy set out since the Xth National Congress of the CPV and One Year as Non-permanent member of the UNSC," p.4.

483 "Statement by H.E. Ambassador Le Luong Minh, Permanent Representative of Viet Nam, Chairman of the Security Council Committee Established Pursuant to Resolution 1132 (1997) Concerning Sierra Leone at the Meeting of the Security Council on Agenda Item Briefing of Security Council subsidiary bodies," Permanent Mission of the Socialist Republic of Vietnam to the United Nations, December 14, 2009, http://www.vietnam-un.org/en/vnun.php?id=172\&cid=1.
} 
Highlands and in the North West, ${ }^{484}$ almost all Vietnamese officials interviewed shared an optimistic view that domestic stability would discourage outside intervention. ${ }^{485}$ Specifically, one official argued that "Vietnam should not be too sensitive to RtoP or think that one day it could be punished on RtoP grounds or become a victim." 486 This official believed that what happened in some African countries would be less likely to occur in Vietnam given the existence of established legal frameworks in the country that would help manage the domestic situation in a way that would prevent mass atrocities and repression from occurring. Put differently, proper management of internal issues would not create opportunities for outsiders to intervene in the internal affairs. The belief that RtoP situations in some of African countries would be less likely in Vietnam therefore helped remove the fear among Vietnamese officials of the possibility that RtoP could be used as pretext by outsiders to intervene in domestic affairs.

In short, the most notable attitudinal change among the group of Vietnamese officials in New York was that they became more comfortable with, and supportive of, RtoP. This attitudinal change was primarily because of a persuasion process through which Vietnamese officials finally came to judge that RtoP was less threatening than they had thought before. Of equal importance was the effect of learning. Through direct involvement in the Council's work, Vietnamese officials came to acknowledge the increasing role of the UN and other international bodies in assisting states. At the same time, knowledge gained from this learning process helped remove the fear of the possibility of RtoP situations in Vietnam. Positive attitudinal change toward RtoP was reflected in public statements in two ways. First, Vietnam stated that it saw RtoP as necessary and urgent in today's world. Second, Vietnam offered support for the role of the

\footnotetext{
${ }^{484}$ Interview by author in Hanoi, February 10, 2012,

485 Interview by author in Hanoi, January 31, 2012; March 26, 2013; April 3, 2013.

${ }^{486}$ Interview by author in Hanoi, January 31, 2012.
} 
international community in assisting states in the need to fulfil their responsibility to protect.

\section{Social influence as an explanation}

Social influence as an alternative explanation also helps provide insights into Vietnam's increasingly positive attitude toward RtoP. In joining the UNSC, the Vietnamese leadership placed a lot of emphasis on improving its image and status. In 2005, a MOFA research project stated that "Vietnam's decision to bid for non-permanent membership in 2008-2009 was a major political decision in the country's process of integrating in the world community and improving its status in the international arena, and at the same time showing its determination to shoulder the burden with others in the world community." 487 In other words, participation in the UNSC was expected to "contribute to increasing Vietnam's credibility through showing the spirit of responsibility toward issue of international peace and security and the implementation of obligations of an international citizen." ${ }^{, 48}$ At the 2005 World Summit, Foreign Minister Nguyen Dy Nien announced Vietnam's decision to run for a non-permanent seat of the UN Security Council for the term 2008-2009 in order to "make greater contribution to the work of the UN." $" 489$

In 2007, Foreign Minister Pham Gia Khiem, in a review of the country's external relations, described the successful bid for a non-permanent seat in the UNSC as a remarkable achievement in the country's multilateral diplomacy,

\footnotetext{
${ }^{487}$ MOFA Department of International Organizations Research Project "On the Role of the UNSC and Vietnam's Future Participation," (2005), Introduction.

${ }_{488}$ Ibid., p. 92.

489 "Statement by H.E. Mr. Nguyen Dy Nien, Minister of Foreign Affairs of the Socialist Republic of Vietnam to the $60^{\text {th }}$ Session of the United Nations General Assembly," the United Nations, September 21, 2005, http://www.un.org/webcast/ga/60/statements/viet050921eng.pdf.
} 
reflecting Vietnam's credibility in the eyes of the world community. ${ }^{490}$ With that achievement, among others, the foreign minister expected that external relations in 2008 would further contribute to the country's increased role and status through the creative and proactive involvement in international institutions. With reference to the UNSC, it was recommended that Vietnam work to "contribute in a responsible and effective manner for the Council to fulfil its mandate of maintaining international peace and security.",491

Showing the spirit of responsibility means having a view on every issue debated. Indeed, Vietnam's officials were sensitive to criticism that they have long expressed their positions in general terms. ${ }^{492}$ In particular, Vietnamese officials in New York found that they had to speak on peace and security concerning particular countries such as those in Africa where Vietnam had virtually no interests. They frequently had insufficient background information to quickly build a national position. ${ }^{493}$ As internal documents reveal, Vietnamese officials were especially sensitive about how others would respond to their statements and the way the country would vote on issues before the Council. ${ }^{494}$

With regard to RtoP, Vietnamese officials took a position on all three pillars and publicly raised their concerns on some points. This was in marked contrast with the case of the ARF a decade before when state representatives were instructed to keep silent throughout the PD discussions and told only to speak if

\footnotetext{
${ }^{490}$ Phạm Gia Khiêm, "Đối ngoại Việt Nam năm 2007: Góp phần thiết thực cho sự nghiệp xây dựng và Bảo vệ Tổ quốc Xã hội chủ nghĩa" [Vietnam's External Relations in 2007: Contribution to the Cause of National Construction and Defence], Tạp chí Cộng sản 784 (2008): 21.

${ }^{491}$ Ibid., 23.

${ }^{492}$ MOFA Department of International Organizations Presentation at the 26th Diplomatic Conference (2008) "Some Initial Thoughts on the Increased Participation in the Process of International Cooperation Toward the Implementation of Vietnamese Foreign Policy set out since the Xth National Congress of the CPV and One Year as Non-permanent member of the UNSC," p. 2.

${ }^{493}$ MOFA Department of International Organizations Research Project on "Vietnam and Its first non-permanent membership at the UNSC (2008-09): Experiences and Lessons," (2012), p. 58. ${ }^{494}$ Ibid.
} 
required. On the contrary, concerns of image forced Vietnamese officials at the Security Council to raise their own voice. Speaking on their own helped state representatives to be seen as confident and up to the task at this global institution.

In addition, acting in a responsible manner required making a concrete contribution to the work of the Council. In relation to RtoP, Vietnamese representatives - taking over the presidency of the Council in July 2008 and October 2009 - chose the protection of children and women in armed conflicts as a topic for discussion. They believed that this was an area where Vietnam could make a concrete contribution to the Council's debates, given the country's historical experiences during the wars and achievements recorded in the subsequent national reconstruction process. ${ }^{495}$ Further, internal documents show that choosing the topic of the protection of women during the month of October 2009 arguably provided an opportunity to show Vietnam's policy towards women, achievements recorded and to "stamp Vietnam's imprimatur before the end of the terms as a non-permanent member." 496

Addressing issues at the Council also required Vietnamese officials to take into consideration - as a guiding principle - the positions and interests of a wider group of participants, including powerful states, concerned states, regional states, and ASEAN members. ${ }^{497}$ Specifically, officials were instructed to actively coordinate their position with China, Russia, ASEAN members and members of the Non-Aligned Movement (NAM) inside and outside the UNSC. ${ }^{498}$ Officials admitted in an interview that regular consultations were held with core NAM

\footnotetext{
${ }^{495}$ MOFA Department of International Organizations Memo, "On Our Second Presidency of the UN Security Council in October 2009,” no. D88, dated May 28, 2009.

496 Ibid.

497 Ibid., p.6.

${ }^{498}$ MOFA Department of International Organizations Presentation at the 26th Diplomatic Conference (2008) "Some Initial Thoughts on the Increased Participation in the Process of International Cooperation Toward the Implementation of Vietnamese Foreign Policy set out since the Xth National Congress of the CPV and One Year as Non-permanent member of the UNSC," p. 4.
} 
members such as Cuba, India, Algeria, Indonesia, Egypt, South Africa and Brazil. $^{499}$ Given the number of NAM members at the Council is always four at minimum and eight at maximum, ${ }^{500}$ and that like-minded states including China and Russia are always there, Vietnam's decisions primarily reflected the shared position of these reference groups.

Vietnam's position on RtoP was no exception. Deputy permanent representative Bui The Giang told the debates on Ban Ki-moon's report in 2009 that Vietnam "associates itself with the statement made by the distinguished representative of Egypt on behalf of the Non-Aligned Movement."501 By this time, a majority of NAM members had endorsed RtoP, at least in principle. ${ }^{502}$ The strongest opponents in the group included Cuba and Sri Lanka, for instance. However, they constituted a distinct minority and individually they did not have much influence on Vietnam's foreign policy. ${ }^{503}$ China and the US, though initially RtoP opponents, also came to recognize RtoP. ${ }^{504}$

In short, concerns over image and "not rocking the boat" also help explain Vietnam's positive attitude towards RtoP in general. However, what is notable in the case of the UNSC is that there is no single critical moment that caused the

\footnotetext{
${ }^{499}$ Interviews by author in Hanoi, December 30, 2011; February 10, 2012.

${ }^{500}$ MOFA Department of International Organizations Research Project "On Vietnam and the first non-permanent membership at the UNSC (2008-2009): Experiences and Lessons," (2012), p. 49.

501 "Statement by H.E. Ambassador Bui The Giang, Deputy Permanent Representative of Viet Nam, at the General Assembly's Plenary Meeting on Responsibility to Protect (R2P)," Permanent Mission of the Socialist Republic of Vietnam to the United Nations, July 24, 2009, http://www.vietnam-un.org/en/vnun.php?id=151\&cid=23.

502 "Statement by H.E. Ambassador Maged A. Abdelaziz Permanent Representative of Egypt on Behalf of the Non-Aligned Movement on Report of the Secretary-General," the International Coalition for the Responsibility to Protect, July 23, 2009, http://responsibilitytoprotect.org/NAM_Egypt_ENG(1).pdf.

${ }^{503}$ The most notable development in relation to the XI National Congress of the Communist Party of Vietnam held in 2011 was that the group of traditional friends, including Cuba, was removed from the final document of the Congress.

${ }^{504}$ On China and RtoP, see Liu Tiewa, "China and Responsibility to Protect: Maintenance and Change of Its Policy for Intervention,” The Pacific Review 25, no. 1 (2012): 153-73.
} 
sudden attitudinal change from opposing to supporting as happened in the two previous chapters.

\section{Mimicking as an explanation}

Mimicking is the act of copying the behaviour of others in a group. Johnston argues that mimicking is an efficient means for a novice to adapt to an uncertain environment. Put differently, it is a safe option for a novice in an uncertain environment to copy what all other members do, without knowing the costs and benefits of doing so. In the framework of international institutions where new participants are unfamiliar with the procedures, routines and language of interaction, mimicking involves the borrowing these procedures and routines and talking about the issues that are central to the institutions.

Johnston also argues that for a state as a new participant in an institution, mimicking can lead to lock-in effects in the three following forms: (i) the development at the domestic level of specialized organizations to handle policy toward such institutions; (ii) the adoption on the part of state representatives of certain standard operating procedures such as working procedures, routines or modes of operation; and (iii) the acceptance on the part of those state representatives of the discursive practices of the institution such as forms of argument and articulation. ${ }^{505}$

There is some evidence of mimicking on the part of the Vietnamese officials while at the UNSC and especially with regard to RtoP. Being novices in the working environment of the Security Council, Vietnamese officials had to follow others to participate in the deliberations and resolutions of RtoP situations. In particular, they participated in the resolutions of RtoP-related issues and started using the language of responsibility to protect without a clear understanding of the

\footnotetext{
505 Johnston, Social States, chapter 2, 45-52.
} 
concept. They also did not have clear preferences about RtoP as they did in the case of ASEAN and the ARF. However, what is notable is that through participation in these deliberations Vietnamese officials came to accept that having a say on issues debated at the Council, even those where Vietnam had virtually no interests, was a standard mode of operation. In addition, Vietnamese officials eventually dropped the cautious approach to RtoP that they initially pursued and adopted a more positive posture which latter paved the way for persuasion to occur, leading to the endorsement of RtoP as an emerging norm.

Given noviceness is the key individual feature conducive to socialization, particularly mimicking, the following section looks at the characteristics of Vietnamese officials as genuine novices at the Security Council and how they adapted to this new working environment. For Vietnamese officials in New York, a lack of familiarity with the procedures, routines, and how to deal with the intensity and huge workload at the Security Council were considered significant challenges. ${ }^{506}$ Chairing the Council's meetings proved to be the most challenging task. $^{507}$ The Vietnamese Permanent Representative Le Luong Minh confirmed that the most intense period and the most complicated issues that Vietnam had to deal with came in July 2008 during its first presidency. ${ }^{508}$ Assuming this position, the Vietnamese officials had to hold various consultations and prepare numerous documents such as speeches, statements of the President, and resolutions. ${ }^{509}$

\footnotetext{
${ }^{506}$ MOFA Department of International Organizations Research Project "On the Role of the UNSC and Vietnam's Participation in the near Future," (2005), pp. 93-4.

${ }^{507}$ MOFA Department of International Organizations Memo, "Vietnam assumes the $2^{\text {nd }} \mathrm{UN}$ Security Council Presidency in October 2009," no. 660-BC/BCSD-TCQT-m, dated September 16, 2009, p.2.

508 "Interview with Ambassador Le Luong Minh by a Vietnam News Agency correspondent on Vietnam's activities during its Presidency," Ministry of Foreign Affairs, September 25, 2012, http://www.mofahcm.gov.vn/vi/mofa/cs_doingoai/nr070523093001/ns080801135812.

${ }^{509}$ Ibid. In this month, about 40 meetings at the Ambassadorial level, including open and closed meetings, were held; six resolutions, three statements by the President and five press releases adopted.
} 
In addition, the lack of background information and in-depth knowledge on the part of the Vietnamese officials of the issues debated at the Council was also a great concern. ${ }^{510}$ It was acknowledged in the 2005 MOFA research project that Vietnam had not yet built a diplomatic corps with working experience in multilateral settings and with specialized knowledge of the Security Council agenda items, such as regional issues in Africa, the Middle East, anti-terrorism and non-proliferation of weapons of mass destruction. ${ }^{511}$ Officials therefore had to carefully chart out a roadmap of participation, anticipate issues that could be discussed at the Council and prepare positions on each item so as to be able to deal with them in an effective manner when taking office. ${ }^{512}$ For example, six major issues were expected to be high on the Council's agenda in 2008, namely Myanmar, the nuclear issue on the Korean Peninsula, Iran, the Middle East, Kosovo and Darfur (Sudan). ${ }^{513}$ Unfortunately, the list did not end there. Reality showed that in 2008 Vietnam had to deal with other issues of a complicated nature that came unexpectedly such as Kenya, Zimbabwe, the Thai-Cambodia conflict, and the conflict in South Ossetia. ${ }^{514}$

Thus in terms of capacity building, the two most important objectives for Vietnamese officials as novices were: (i) to master the working procedures and routines at the Council and (ii) to improve their knowledge of the agenda items. In this respect, Vietnam's decision to join the UNSC was described as an effort to

\footnotetext{
${ }^{510}$ MOFA Department of International Organizations Research Project "On Vietnam and the first non-permanent membership at the UNSC (2008-2009): Experiences and Lessons," (2012), p. 58. Vietnamese officials found the lack of background information and positions of the related parties on situations in Abkhazia and South Ossetia the most challenging for them to build a quick position.

${ }^{511}$ MOFA Department of International Organizations Research Project "On the Role of the UNSC and Vietnam's Participation in the near Future," (2005). Among others, a training programme on understanding the UNSC and improving capacity building for MOFA officials and those from concerned Ministries was developed and sponsored by the UNDP.

${ }_{512}$ The list included approximately 60 items, grouped into general and regional issues.

${ }^{513}$ MOFA Department of International Organizations Research Project "On Vietnam and the first non-permanent membership at the UNSC (2008-2009): Experiences and Lessons," (2012), p.65. ${ }^{514}$ Ibid.
} 
"jump into the high seas" to test the waters. ${ }^{515}$ In the same vein, Vietnam could not be aware of the specific benefits it might gain by joining the Council. Rather, it could only anticipate some. As mentioned in the previous section, the country's leadership saw an opportunity to improve Vietnam's international standing by joining the UNSC, among others. ${ }^{516}$

The 2005 MOFA research provided some success stories that Vietnam could emulate. For example, Japan, Germany, Canada and India were identified as non-permanent members whose contribution to UN peace-keeping operations had helped project their influence. Specifically, their positions and preferences were taken into consideration when the Council decided how to use the resources for such activities. Similarly, Vietnam believed that if it considered contributing personnel to peace-keeping operations, not only would its voice be heard on the issue but it would also be in a more advantageous position in the decision-making process of the deployment, thus preventing the possible abuse of Vietnamese personnel for inappropriate purposes. Another example was Morocco in its 19921993 term. This non-permanent member had successfully projected its influence over the issue of Western Sahara at a time when the Polisario Front was unable to do so because its main ally Algeria was not a member of the Security Council. As a non-permanent member, Vietnam also hoped that it could exert some influence on regional issues. ${ }^{517}$

However, reality showed that Vietnam in 2008-2009 did not have much chance to apply these lessons so as to maximize its expected benefits. For example, Vietnam has not yet contributed personnel to peace-keeping missions

\footnotetext{
515 Ibid.

${ }^{516}$ It was anticipated that participation in the UNSC would help improve Vietnam's credibility; advance the national positions; put it in a better bargaining position and strengthen bilateral relations with the $\mathrm{P} 5$.

${ }^{517}$ MOFA Department of International Organizations Research Project "On the Role of the UNSC and Vietnam's Participation in the near Future," (2005).
} 
although there have been some positive signs of progress. ${ }^{518}$ Similarly, it was difficult to measure Vietnam's influence on regional issues. Although officials played an active role in the deliberations and resolution of regional issues such as Myanmar (its constitutional referendum and debate that followed Cyclone Nargis) or Thai-Cambodia clashes over the Preah Vihear Temple, these regional issues also put them in a more difficult situation, if not a dilemma, because the states concerned were all ASEAN members.

The Vietnamese Permanent Representative Le Luong Minh confirmed in an interview that these two regional issues, together with Iran and Zimbabwe, were important and of considerable sensitivity during Vietnam's presidency in July $2008 .^{519}$ In the case of Myanmar, pressure not only came from Western countries, but also from China as a traditional like-minded state. The Vietnamese saw signs on the part of the Chinese that they wanted to "kick the ball" to Indonesia and Vietnam, pushing them to the forefront of the deliberations. ${ }^{520} \mathrm{On}$ the Thai-Cambodia conflict, pressure came from Cambodia. Rather than supporting Cambodia's effort to bring the case to the Security Council, Vietnam argued that it was a legal issue, thus stressing the role of ASEAN as a mediator. As a consequence, the Cambodian delegation felt somewhat unhappy. ${ }^{521}$ In short, expected benefits turned out to be more difficult to achieve in reality.

Vietnam's decision to go along with RtoP should also be examined against this backdrop. As the chronology shows, state representatives did not initially anticipate any concrete benefits that Vietnam could enjoy by going along with the

\footnotetext{
518 "Vietnam Prepare to Join UN Peace keeping Forces," ThanhNien Online, November 17, 2012, http://www.thanhnien.com.vn.

519 "Interview by Ambassador Le Luong Minh with a Vietnam News Agency Correspondent on Vietnam's Activities during its Presidency of the Security Council," Ministry of Foreign Affairs, accessed September 25, 2012,

http://www.mofahcm.gov.vn/vi/mofa/cs_doingoai/nr070523093001/ns080801135812.

${ }_{520}$ MOFA Department of International Organizations Report "On the UNSC's activities and Vietnam's Participation in April, 2008," no. 554/BC-BNG-TCQT, dated May 21, 2008, p. 4.

${ }^{521}$ Interview by author in Hanoi, December 30, 2001.
} 
norm. Rather, they saw potential implications for the state's sovereignty. Vietnamese officials took part in the deliberations and resolutions of RtoP-related issues but without a clear understanding of the concept. MOFA officials admitted in the interview that no research on RtoP had been done in the foreign ministry. ${ }^{522}$ As a result, many officials assigned to work at the mission in 2008-2009 did not have a clear understanding of RtoP upon their arrival.

However, since RtoP was directly invoked and covered in various items on the Council's agenda, state representatives could not avoid having a view. First, engaging in deliberations and resolutions of RtoP-related issues is an obligation of any member at the Security Council. Second, by engaging in these deliberations Vietnamese officials wanted to show that they were acting in a responsible manner. Third, since Vietnam had expressed a more positive attitude toward RtoP at the 2005 World Summit, state officials had to act in a manner consistent with that, rather than isolating themselves from the debates. So, in addition to the working requirement, Vietnam's participation in RtoP deliberations was also driven by image concerns.

Therefore, some important points could be drawn from Vietnam's engagement in RtoP deliberations. First, this was strictly an act of mimicking: by taking part in RtoP deliberations - though without a clear understanding of the concept and the benefits of doing so - Vietnamese officials were trying to adapt to a new working environment and exposing themselves to a new issue. In addition, through participation in RtoP deliberations Vietnamese officials wanted to be seen by others as competent communicators. In this sense, mimicking on the part of Vietnamese officials was driven by image concerns. As such, it is a function of social influence.

\footnotetext{
${ }^{522}$ Interview by author in Hanoi, January 31, 2012.
} 
Second, through their participation in the deliberations and resolutions of RtoP-related issues as well as other items on the Council's agenda, Vietnamese officials came to accept that having a say on issues debated at the Security Council was a standard mode of operation. Refraining from speaking, observing and hiding behind others as Vietnamese officials did at the ARF in 2001 thus became irrelevant at best and costly at worse, since priority was given to building a good image of Vietnam as a responsible Council member. This is exactly the lock-in effect of mimicking that Johnston points out: the acceptance on the part of novices of working procedures, routines or modes of operation of the group.

Finally, engagement in the deliberations on RtoP and related issues facilitated a better understanding of the concept on the part of the Vietnamese officials. This then led to a shift from a defensive posture to a more active one on the issue. It should be noted that, given the lack of a clear understanding of the concept and the fear of negative implications, Vietnamese officials initially approached and used the language of RtoP with caution. For example, a Vietnamese representative - speaking at a Council meeting on protection of civilians in armed conflict in November 2007 - emphasized the seemingly inviolability of states' sovereignty by adding the phase "within its jurisdiction" to states' primary responsibility for the protection of their own peoples. ${ }^{523}$ That phrase was however dropped from subsequent statements in 2008-2009, as Vietnamese officials became more convinced that RtoP was less threatening and that states' sovereignty was fully protected. The statement delivered at the General Assembly Plenary Debate on RtoP in July 2009 was a clear example of this shift. The language in the statement was described by outsiders as

${ }^{523}$ The United Nations, "Security Council's meeting on Protection of Civilians in Armed Conflict," 20 November 2007, S/PV.5649 (Resumption 1), p. 21-22. Emphasis added. 
"unexpectedly constructive.",524 In this sense, mimicking helped facilitate persuasion.

\section{Conclusion}

This chapter argues that Vietnam changed its position from being opposed to becoming more engaged with RtoP, especially in 2008-2009, was because of socialization. An alternative explanation which argues that Vietnamese officials became more engaged with the RtoP was to gain material incentives offered by RtoP advocates or that they found themselves under great pressure or even threat if not supporting the norm was not plausible in this case study. Analysis throughout the chapter shows no sign of material side-payments that Vietnamese officials thought they could gain by adopting RtoP. The 2012 MOFA review of Vietnam's experiences and lessons after two years participating in the UNSC did not mention any material gains that Vietnam had expected for or achieved. Instead, it emphasized that Vietnam's participation in this global institution was another step to implement Vietnamese foreign policy and contributed to the consolidation of Vietnam's credibility and status in the international arena. ${ }^{525}$ In addition, Vietnamese officials at the Security Council were not under great pressure to go along with RtoP as they had been in the PD deliberations and negotiations for an ASEAN HRB either.

In this chapter a combination of mimicking, social influence and persuasion, help explain the supportive position taken by Vietnamese officials. Social influence helps explain Vietnam's endorsement of RtoP in principle. And together with mimicking, it helps facilitate persuasion which led to an attitudinal

\footnotetext{
524 "Report on the General Assembly Plenary Debate on the Responsibility to Protect," the International Coalition for the Responsibility to Protect, September 15, 2009, http://www.responsibilitytoprotect.org/ICRtoP\%20ReportGeneral_Assembly_Debate_on_the_Responsibility_to_Protect\%20FINAL\%209_22_09.pdf. ${ }^{525}$ MOFA Department of International Organizations Research Project on "Vietnam and Its first non-permanent membership at the UNSC (2008-09): Experiences and Lessons,” (2012), p 56.
} 
change among a small group of Vietnamese officials in a more direct way: having a better understanding of RtoP caused this group to see the concept as less threatening. They became more comfortable with it and this positive attitudinal change was reflected in various public statements.

In terms of theory, the interactions between the three socialization processes in leading to Vietnam's endorsement of RtoP thus confirm Johnston's theory, particularly with regard to mimicking. Mimicking in this chapter is both condition for and an effect of persuasion and social influence. This is exactly what Johnston has argued. ${ }^{526}$ In addition, the empirical findings in this chapter show that socialization in the truest sense - internalization of new norms through persuasion - can occur and perhaps more notably can even occur in the UNSC which was initially chosen as a 'least-likely' case because of its institutional features. The findings raise questions about the link between persuasion and particular institutional designs asserted in Johnston's work. Some institutional features supposedly conducive to socialization processes - the size of the group, for instance - did not seem to matter much. Contrary to what theory might expect, persuasion occurred in the UNSC's deliberations even when these involved a large group of participants.

How durable is this new positive attitude toward RtoP? This is an important question because Johnston argues that persuasion is a micro-process that leads to the most durable and self-reinforcing pro-norm behaviour. If the frequency of references to RtoP can be considered a measurement of a positive attitude, his argument could be challenged. By this measure Vietnam's support for RtoP in New York might even be seen as a deceptive effort. For example, when the use of force on RtoP grounds was endorsed in Libya in 2011, Vietnam did not raise its voice. A senior official said in an interview that since Vietnam was no

${ }^{526}$ Johnston, Social States, 24. 
longer a non-permanent member, it would be unwise for Vietnam to publicly support or oppose any concerned parties in the conflict. ${ }^{527}$ However, on the occasion of the $16^{\text {th }}$ session of the Human Rights Council on February 28, 2011 Deputy Foreign Minister Pham Binh Minh said that Vietnam and some other states such as Russia and Cuba did not support the use of force to intervene in Libya. ${ }^{528} \mathrm{He}$ also stressed that any international action should be based on consensus.

As internal documents reveal, Vietnam was concerned about the growing trend of major powers using force against weak states: Yugoslavia (1999), Iraq (2003), Georgia (2008), and Libya (2011). ${ }^{529}$ In the Vietnamese perspective, the use of force in the Libya case - albeit authorized by the UNSC - was an act of intervention in a sovereign state in the name of humanitarian intervention to support a rebel group and achieve regime change. This could create a dangerous precedent for international relations and pose great challenges for other sovereign states facing political upheavals that might lead to conflict. ${ }^{530}$ The situation in Libya and across North Africa in 2011 was studied through the lens of the struggle among powers in which the United States and other Western countries on one side increased their intervention activities and China and Russia on the other side proposed non-intervention. ${ }^{531}$ A senior Vietnamese diplomat also admitted in an interview that internal debates within MOFA on Libya and other African

\footnotetext{
${ }^{527}$ Interview by author in Hanoi, March 26, 2013.

528 Minh Khôi, "Việt Nam ứng cử Hội đồng Nhân quyền Liên Hợp Quốc: Vì một thế giới hòa bình, thịnh vượng và công bằng" [Vietnam Bids for Membership at the UN Human Rights Council: Striving for a World of Peace, Prosperity and Equality], Thế giới và Việt Nam, March 9, 2011, http://www.baomoi.com/Home/DoiNoi-DoiNgoai/www.tgvn.com.vn/Viet-Nam-ung-cuHoi-dong-Nhan-quyen-LHQ-Vi-mot-the-gioi-hoa-binh-thinh-vuong-cong-bang/5838581.epi. ${ }^{529}$ MOFA Foreign Policy Department "On the Draft of the Report on updates on Situations in Libya and other countries in Middle East and North Africa," dated March 25, 2011.

${ }^{530}$ MOFA West Asia and Africa Department Report "On Political Upheavals in the Middle East and North Africa: Situations, Causes and Implications,” dated March 28, 2011.

531 Ibid.
} 
countries in 2010-2011 focused more on the implications for international relations in general, than on RtoP. ${ }^{532}$

Despite this, Vietnam's failure to support the use of force in Libya should not be seen as a step back in its support for RtoP. Vietnam has not yet endorsed the use of force as one of the collective actions taken by the international community on RtoP grounds. Similarly, just because there was less talk about RtoP should not be seen as conclusive evidence of deception. As David Capie observes, representatives of Southeast Asian governments appear less interested in RtoP in Southeast Asia than when they were in New York. ${ }^{53}$ However, Vietnam's relative silence at the regional level is mainly due to bureaucratic factors: those who spoke in New York did not always speak in regional institutions such as ASEAN or the ARF.

In addition, the fact remains that even within MOFA there has not been a single consistent position on RtoP. For example, there was no reference to RtoP in the internal documents prepared by the Department in charge of African Affairs on the Libya case when the use of force was authorized on RtoP grounds. Thus except for those who have worked in the UN in 2008-2009, there is still a lack of understanding on RtoP among officials in Hanoi. In the most recent review of Vietnam's integration process, the lack of a consistent position on similar issues raised at different fora such as democracy, human rights, and religious freedom, was seen an weakness which reflected a lack of coordination among MOFA departments and that needed to be properly addressed. ${ }^{534}$ Therefore, it would be fair to argue that Vietnam's positive attitude toward RtoP while at the UNSC was wholly situational.

\footnotetext{
532 Interview by author in Hanoi, February 21, 2012.

${ }^{533}$ David Capie, "The Responsibility to Protect Norm in Southeast Asia: Framing, Resistance and the Localization Myth," The Pacific Review 25, no. 1 (2012): 75-93.

${ }^{534}$ MOFA Foreign Policy Department, "Overview Report on the Ministry-level Research Project on International Integration toward the Implementation of the Foreign Policy Orientation adopted at the XIth National Congress of the CPV," (2012), p.25.
} 
Vietnam's positive change in attitude toward RtoP as a result of persuasion should therefore not be exaggerated. Attitudinal change was observed on a small group of Vietnamese officials who were directly involved in the Council's work in 2008-2009. There was even a range of views among those officials who found RtoP less threatening. A diplomat who once said that he no longer saw RtoP as humanitarian intervention admitted in the interview that they had to deal with RtoP on a case-by-case basis and RtoP implementation was in reality still a political struggle. ${ }^{535}$ Further, while almost all officials interviewed acknowledged the moral significance of RtoP, they said they became somewhat more conservative after the Libya case and concerned about the trend of "double standards" in RtoP implementation. ${ }^{536}$ And in the most recent review of Vietnam's participation in the Security Council in 2008-2009, democracy, human rights, institutional reforms and RtoP are seen as controversial issues that Vietnam should be well-prepared to respond to if there are attempts by Western governments to put them high on the Council's agenda. This, it was noted, would be especially important if Vietnam wants to bid for another term as a nonpermanent member. ${ }^{537}$

\footnotetext{
${ }^{535}$ At the UN, as Vietnamese officials observed many developing countries still oppose invoking RtoP in particular situations. The struggle between those support and those oppose will therefore continue, especially when no consensus was reached at the debate on Ban Ki-moon's report on the implementation of RtoP held in 2009.

${ }_{536}^{53}$ Interview by author in Hanoi, March and April 2013.

${ }^{537}$ MOFA Department of International Organizations Research Project "On Vietnam and the first non-permanent membership at the UNSC (2008-2009): Experiences and Lessons," (2012), p.140.
} 


\section{CHAPTER VII}

\section{CONCLUSION}

This thesis has explored Vietnam's involvement in three important international institutions, namely the Association of Southeast Asian Nations, the ASEAN Regional Forum and the United Nations Security Council. It has used socialization theory to investigate how participation in these social environments has changed Vietnam's behaviour and preferences on some key political and security issues, including human rights, preventive diplomacy and the responsibility to protect. This final chapter provides a brief summary of the main empirical findings. It then reflects on the implications for socialization theory and for future research.

\section{Empirical findings}

The main empirical finding in the thesis is that there is evidence of socialization occurring across three distinct case-studies, eliciting pro-norm behaviour on the part of the Vietnamese officials, though to varying degrees. In chapter four, persuasion did not work to elicit Vietnam's cooperation on the creation of the ASEAN Human Rights Body. On the contrary, social influence occurred, providing a more plausible explanation for Vietnam's endorsement of the initiative: the decision was made primarily because of peer pressure and pressure resulting from membership. Vietnamese officials found themselves in the minority and image concerns of wanting to appear to be a responsible member of ASEAN prevented them from blocking the process toward the creation of such a mechanism.

The climax of the negotiations on the HRB came at the eighth meeting of the ASEAN HLTF where the ten participants were divided into two groups: those from older ASEAN members supported the immediate creation of the HRB and 
those from newer members, namely Cambodia, Laos, Myanmar and Vietnam were reluctant. Unable to arrive at a consensus, the HLTF participants referred the issue to their Foreign Ministers for a decision. The critical moment came at the second meeting of the ASEAN Foreign Ministers when Deputy Foreign Minister Le Cong Phung finally announced Vietnam's decision to go along with the HRB initiative, although this was conditioned upon the completion of the TOR and ensuring the HRB would only have consultative status. ASEAN SecretaryGeneral Ong Keng Yong confirmed that Phung's announcement had settled the controversy and consensus was finally reached on the creation of the HRB.

The decision to support the HRB was made in a situation where Vietnam found itself in an uncomfortable minority. According to a Vietnamese senior official, even the like-minded states, Laos and Myanmar, finally came to agree with the initiative. Other officials noted that Vietnam did not want to be seen as blocking the process and worried that, especially in the context of ASEAN Community building, opposing the creation of the HRB might negatively affect the country's credibility and status in ASEAN.

The endorsement of the HRB demonstrates a change in Vietnam's preferences whereby it broke the taboo of avoiding intra-regional discussions on human rights issues. Notably, this preference change took place in a context where no concrete material side payments or threats of sanctions were present. There was no evidence that the activist group of states had offered material rewards in exchange for support from the reluctant ones. Their pressure throughout the negotiations did not constitute a threat, either. There was also no sign of any attempts by Western governments to intervene in the work of the Task Force so as to influence the progress on the HRB negotiations, even though human rights issues have long been an obstacle in bilateral relationships between individual ASEAN members - and the Association as a whole - and the West. 
In chapter five, persuasion did not work to change Vietnam's position from opposing to supporting the adoption of the Preventive Diplomacy Papers at the $8^{\text {th }}$ ARF in 2001. Rather, social influence occurred and led to the acceptance of the PD papers on the part of Vietnamese officials. Choosing China as a behaviour exemplar, the Vietnamese participants in the chairmanship of the ARF had no choice but to follow their Chinese counterparts when the latter suddenly changed its position and supported the adoption of PD Papers as a part of the agenda. In this sense, Vietnam's decision to adopt the PD papers was an act of mimicking. However, such an act of mimicking came about as a result of social influence. As such, it is not mimicking in strict sense as Johnston suggests that is to survive in a novel environment.

Vietnam's decision was made at the ARF SOM in May 2001 in which the agenda for the $8^{\text {th }} \mathrm{ARF}$ was considered and there was no evidence that the activist group of states had offered material rewards in exchange for support from the reluctant ones. Similar to the situation in the negotiations on the HRB, peer pressure and pressure resulting from being the Chair of the ARF played the key role in eliciting Vietnam's changed behaviour. Prior to this ARF SOM, differences remained between the two opposing groups - with Japan, the US, Australia and Singapore in the activist group and China, Russia, India, Vietnam and almost all ASEAN members in the reluctant one - on whether or not to adopt PD papers. Vietnamese participants did not anticipate a consensus between the two groups as likely given what they perceived as the hardened attitudes on the part of China, Russia and India. They believed the Chinese were still cautious and resolutely opposed to moving the ARF onto the PD phase. In that context, Vietnamese participants felt somewhat safe to pursue a strategy of slowing down the ARF's transition from confidence building measures to preventive diplomacy.

However, as a senior Vietnamese official noted, at the May 2001 SOM the Chinese suddenly changed their position from opposing to supporting the adoption of these PD documents, thus generating consensus among major powers 
to settle the debate. Vietnam's efforts to delay the adoption of the PD papers failed as a result. Since the role of ASEAN was limited to taking an accommodation position vis-à-vis the preferences of major powers, Vietnam as the ARF Chair had to follow the major powers and adopt the three papers as a part of the $8^{\text {th }}$ ARF agenda. However, the decision did not automatically lead to a change in preferences and Vietnamese officials in subsequent ARF meetings still sought ways to slow down the Forum's transition from confidence building to preventive diplomacy and prevented its institutionalization.

Chapter six showed how the three socialization processes interacted to generate Vietnam's endorsement of RtoP as an emerging norm. Unlike the two previous chapters where social influence exerted direct effects on Vietnam's decisions to go along with the HRB and the adoption of PD papers, social influence in this chapter helped explain Vietnam's support for RtoP in principle. There was no critical moment that forced Vietnamese officials to change their position from opposing to supporting RtoP. Rather, image concerns and a desire "not to rock the boat" had two indirect influences. First, having a view on RtoP expressing support or concern - was required to show the spirit of responsibility as a non-permanent member of the Security Council, thus avoiding the criticism that Vietnam has long expressed positions only in general terms. Second, in the period 2008-2009 Vietnam found it hard to oppose RtoP because it had been acknowledged and endorsed, albeit to varying degrees, by the majority of UN members. In addition, after Vietnamese Foreign Minister Nguyen Dy Nien had expressed a more positive attitude toward the concept at the 2005 World Summit, continued support for RtoP was needed to demonstrate that Vietnam was acting consistently.

Chapter six also showed how mimicking sheds light on Vietnam's engagement in RtoP deliberations as an effort to adapt to the new working environment at the UNSC. Vietnamese officials engaged in RtoP deliberations and used its language even without having a clear understanding of the concept 
and despite concerns about possible external intervention in Vietnam on RtoP grounds. What is also notable is that mimicking, together with social influence, helped facilitate persuasion which led to attitudinal change among a small group of Vietnamese officials in a more direct way. Accepting RtoP in principle and participating in RtoP deliberations - initially driven by the desire to be seen as a responsible member and competent communicator and to enrich knowledge on the part of the state representatives so as to be capable in the resolutions of RtoP related issues - gradually led to new understanding of RtoP as a less threatening concept. In addition, through "learning by doing" - direct involvement in the resolution of possible RtoP situations at the UNSC - Vietnamese officials became more convinced of RtoP's appropriateness. A group of Vietnamese officials in New York acknowledged the humanitarian aspect of RtoP and its necessity in today's world and came to accept that Vietnam could not isolate itself from the trends of the times.

Empirical findings and alternative explanations for Vietnam's behavioural change

While Vietnam's changed attitude toward endorsing RtoP as a new norm at the UNSC confirms Johnston's argument of truest socialization through persuasion, its changed behaviour to conform to groups' positions in ASEAN on the creation of the HRB and in the ARF on the adoption of the PD papers does not mean norm internalization on the part of Vietnam. As was shown in chapter four and five, Vietnam continued to press for the completion of the TOR before the establishment of the HRB and sought ways to slow down PD process in subsequent ARF's meetings. As such, one can argue that empirical findings in these two chapters support neo-liberal perspective on the role of international institutions in facilitating cooperation among states. Neo-liberals argue that states have fixed material interests before engaging with others and that international institutions are created to facilitate the convergence and pursuit of these material interests. Therefore, the two above decisions made by Vietnam can be seen, in the 
light of neo-liberal arguments, as a reflection of common interests or in the pursuit of possible material side-payments.

There are two problems with neo-liberal explanation regarding Vietnam's decisions to support the creation of the HRB and the adoption of PD papers. First, Vietnam's conformity with groups' positions in these two case-studies is not an evidence of convergence of interests as neo-liberals claim. The creation of an ASEAN HRB and the adoption of PD papers were not in Vietnam's interests. That was why Vietnam had sought way to slow down the two processes.

Second, and more importantly the two decisions were made in situations in which there was no presence of material side-payments. In chapter four there was no evidence that the activist members, individually or collectively, offered Vietnam any material reward in exchange for its support for the creation of the HRB. The same situation can also be observed in chapter five on PD. There was no evidence that the ARF's activist members such as Japan and the US had placed progress on political and security area as a conditionality for deepening biliateral economic and trade cooperation with Vietnam. Therefore, neo-liberalism cannot provide a plausible explanation for Vietnam's changed behaviour, supporting for the creation of an ASEAN HRB and the adoption of PD papers in the ARF.

\section{Empirical findings and Vietnam's foreign policy behaviour}

In terms of foreign policy behaviour, the above empirical findings show the slow but increasingly positive and substantive changes in Vietnam's foreign policy toward cooperation inside international institutions throughout the first decade of the 21 st century. A foreign policy based on diversifying and multilateralizing the country's external relations, and reflected in an increased involvement in international institutions, has gradually transformed the way Vietnam sees itself and others. In the early years of this process, as was shown in chapter five on Vietnam's participation in the ARF, ideological differences embedded in the concepts of friends and foes were the key factor that prevented 
Vietnam from developing closer political and security cooperation. As a result, the 2001 decision to adopt the Preventive Diplomacy documents did not necessarily mean a change in preferences whereby Vietnam supported the ARF's embarkment on its second stage of development. Rather, Vietnam subsequently continued to find ways to try to slow down that process.

However, in 2003 the concepts of friends and foes were replaced with partners and objects of struggle. With the adoption of the Resolution of the 8th Plenum of the Party Central Committee (the IXth tenure) which entitled Strategic Orientations of National Defence in the New Situation. The document reads:

- Those who respect the independence and sovereignty and desire to establish and expand friendly, equally and mutually beneficial relations with Vietnam, should all be our partners.

- Any forces planning or carrying out hostile activities against our objectives in the cause of national construction and defence of the Fatherland should all be objects of struggle.

- However, given the rapidly evolving and complicated current situation, it is necessary to adopt a dialectical perspective: in each object of struggle there are aspects we still need to win support and cooperation; in some partners, there could be some aspects that are different from and contradictory to our interests. ${ }^{538}$

This new approach provided a greater flexibility and more space for expanding and deepening cooperation with those Vietnam had been reluctant to engage with in the past. As a senior official said in an interview, the visit by Vietnamese Defence Minister Pham Van Tra to the United States in November 2003 was a demonstration of this new approach and it marked a new turn in USVietnam relations. ${ }^{539}$ In the ASEAN context, Vietnam softened its tone regarding the struggle aspect of the relationship. The language that distinguished old and

\footnotetext{
${ }^{538}$ Unofficial translation, quoted in Nguyen Nam Duong, "Vietnamese Foreign Policy since Doi Moi: The Dialectic of Power and Identity" (PhD thesis, University of New South Wales, Australia, 2010), 151.

${ }^{539}$ Interview by author in Hanoi, March 25, 2013. On Vietnam-US relations in 2003, see Nguyen Manh Hung, "Vietnam: Facing the Challenge of Integration," Southeast Asian Affairs (2004): 297311.
} 
new ASEAN members, stressing "us-them" differences was dropped. Instead, Vietnam now repeatedly claims to be a responsible member of ASEAN. ${ }^{540}$ Indeed, Vietnam has been determined to transform itself from a member with a modest role to a "proactive and responsible member, playing the leading role in issue areas where it has core interests and competitive advantages." Specifically, the new orientation in Vietnam's participation in ASEAN is to "proactively participate in the work of institutional building and improving decision-making procedures, especially setting up 'rules of the game' within the Organization." 542 This proactive posture is recommended to "be upheld in even a number of sensitive issue areas such as democracy, human rights, religion, national defence and security with a view to protecting our core national interests and that of ASEAN as a whole.",543

Shifting from "being a new ASEAN member" to "being a proactive and responsible member of ASEAN" is not simply a change in language. Rather, it reflects a transformation in the way Vietnam sees itself. Being a new ASEAN member implies at least two things: first, it is to state that differences, in political system and level of development for instance, have been obstacles in the process of deepening ASEAN cooperation; second, in such a position Vietnam could only make contributions to the group within its (normally perceived as limited) capabilities and in its interests. Although differences still remain, ${ }^{544}$ proclaiming itself as "a proactive and responsible member" implies an increased sense of belonging and a higher level of identification with ASEAN. In this sense, the decision to go along with the ASEAN HRB in 2007, albeit reluctantly, is a

\footnotetext{
540 “Phát biểu của Thủ tướng Nguyễn Tấn Dũng nhân ngày ASEAN" [Speech by Prime Minister Nguyen Tan Dzung on the ASEAN Day] Thế giói và Việt Nam, August 7, 2012, http://tgvn.com.vn/Item/VN/ChinhTri/2012/8/9A8441E6138B7A5E/.

${ }_{541}$ MOFA ASEAN Department Research "On the Prospects of ASEAN in the first two decades of the $21^{\text {st }}$ century: Impacts and Vietnam's Strategy,” (2008), p. 96.

542 Ibid.

543 Ibid.

${ }^{544}$ MOFA ASEAN Department "Documents prepared for the $27^{\text {th }}$ Diplomatic Conference," no. 858, dated December 2, 2011.
} 
manifestation of the effort on the part of the Vietnamese officials to act consistently with this new image.

The spirit of Vietnam as an active and responsible member of the world community can be best seen in 2008-2009 when it was a non-permanent member at the UNSC and in 2010 when it held the Chair of ASEAN. ${ }^{545}$ At the UNSC, Vietnamese officials showed that they gained a better understanding of the salience of specific issues for other member states and took into consideration their perceptions and preferences in the decision-making process. As Chair of ASEAN in 2010, Vietnam made concrete efforts to contribute to the building of ASEAN Community, most notably through its proposal of the Master Plan of ASEAN Connectivity adopted at the $17^{\text {th }}$ ASEAN Summit. ${ }^{546}$

\section{Implications for socialization theory}

In terms of theory, the empirical findings in the thesis confirm the plausibility of socialization as a source of cooperative behaviour among state agents within social environments. Socialization in the truest sense internalization of new norms through persuasion - is empirically conceivable as in the case of the UNSC. However, it should also be noted that socialization is not the only most plausible explanation for Vietnam's cooperative behaviour in the three case-studies. As was shown in the case of the UNSC, along with persuasion, learning as an independent variable also played an important part in eliciting attitudinal change on the part of the Vietnamese officials toward RtoP. Persuasion and learning mutually reinforced one another, leading to a new understanding of RtoP among Vietnamese officials.

\footnotetext{
${ }^{545}$ Phạm Gia Khiêm, "Ngoại giao Việt Nam năm 2008 và định hướng năm 2009” [Foreign affairs of Vietnam in 2008 and orientation in 2009], Tap chí Cộng sản 796 (2009): 14-19; Phạm Gia Khiêm, "Việt Nam và nhiệm kỳ chủ tịch ASEAN 2010: Thành tựu của ASEAN và dấu ấn Việt Nam" [Vietnam as ASEAN Chair in 2010: Achievements of ASEAN and the Vietnamese imprint], Tap chí Cọng sản 818 (2010): 8-15.

546 "Master Plan of ASEAN Connectivity," ASEAN, December 2010, http://www.asean.org/archive/documents/MPAC.pdf.
} 
Further, given the fact that Vietnamese officials entered the deliberations with a pre-existing preference of "not being in the minority" there are both rationalist and social elements in Vietnam's decisions to support the norms under examination. As a working rule, "not being in the minority" helps facilitate the effects of social influence. Indeed, as we saw the micro-process of social influence worked across all three case-studies. However, the fact that social influence happened in all three case-studies may lead to the claim that rationalism, rather than socialization, prevails in Vietnam's story. That means Vietnam conforms to groups' positions and norms for rational reasons. One can even go further arguing that social influence thus undermines the explanatory power of socialization theory.

This argument is not persuasive, however. In fact, rationalism in the case of Vietnam totally fits with what Johnston defines as "social thin rationalism" and that is in contrast with "material thin rationalism." ${ }^{547}$ The concept of "thin rationalism" used by Zurn and Checkel in their studies of socialization in Europe refers to "the intentional version of rationalist theory, which argues that agents act on the basis of beliefs and preferences." ${ }^{548}$ By adding "social" to "thin rationalism," Johnston wants to emphasize the sociality of rationalist calculus made by an actor in institutional environments. He argues, "when one speaks of 'normative pressure' in IR, one is talking about conformity for rational reasons but under conditions that are entirely 'social."' In Johnston's view, this sociality comes in two forms: (i) the actor's desire to maximize social status and (ii) a certain degree of its loyalty to the group. "Material thin rationalism" in contrast with "social thin materialism" would therefore refer to conformity under conditions that are entirely "material." Put differently, an actor would conform to a group's

\footnotetext{
547 Johnston, "Conclusion and Extensions: Toward Mid-Range Theorizing and beyond Europe," 1030-31.

${ }^{548}$ Michael Zurn and Jeffrey T. Checkel, "Getting Socialized to Build Bridges: Constructivism and Rationalism, Europe and the Nation-State," International Organizations 59, no. 4 (2005), 1058.
} 
norms in order to maximize material benefits and that this actor could easily shift its loyalty from one group to another.

So what are the social aspects of Vietnam's rational decisions? First, Vietnam's decisions to support for the creation of the HRB, the adoption of PD papers and its endorsement of RtoP can be seen as consequentialist choices: Vietnamese officials came to support groups' positions and associated norms because they did not want to be in the minority. However, these choices were made to achieve social rather than material goals: to build a good image of Vietnam as a responsible member of the groups. More importantly, such a desire for social status (public recognition) can only be achieved at multilateral settings (rather than in bilateral relationships) in which the larger the membership, the wider the public recognition that Vietnam could expect for.

Second, by supporting groups' positions and associated norms Vietnam was showing its loyalty to the institutions it joined which, as Johnston argues, rooted in its increased awareness of its obligations as a member of these groups: ${ }^{549}$ As a member of the ASEAN family, Vietnam was aware that it should not block the process of establishing a human rights mechanism; as the ARF Chair, Vietnam was aware of its responsibility to facilitate and make concrete progress for the Forum to embark on a new stage of development; and at the UNSC, Vietnam was aware of its obligations as a non-permanent member, making concrete contributions to the maintenance of international peace and security.

In short, in the case of Vietnam rationalist and social factors worked together to provide more insights into the process that led Vietnam to change its behaviour toward more cooperative. In this sense, rationalist and social factors are complementary, rather than incompatible. This finding thus contributes to the call for building bridges between constructivism and rationalism - rather than focusing

549 Johnston, "Conclusion and Extensions," 1031. 
on the competitive aspects of rationalist-constructivist debate - by making efforts on "the search for complementarities." 550

Another implication for theory concerns the purported importance of institutional design. While Johnston argues that socialization is more likely to happen in informal, weakly institutionalized and consensus-based institutions such as ASEAN and the ARF, the case of Vietnam shows that socialization also works in a strongly institutionalized institution such as the UNSC which was initially chosen as a "least-likely" case. Moreover, the findings here suggest some institutional features arguably conducive to socialization processes are not as important as Johnston suggests. For example, the size of the group did not seem to matter much. Contrary to theory, persuasion occurred in the UNSC's deliberations involving a large group of participants. Meanwhile, social influence happened in ASEAN deliberations with a smaller group of participants. Similarly, the effects of formal working rules such as deliberation and consensus - arguably conducive to persuasion - were also limited. Johnston suggests an institution with a deliberative mandate and consensus as its decision-making rule should help create a working environment that gives participants some degree of free choice and facilitates flexible cognition when assessing counter-arguments. However, as was shown in chapters four and five, as long as Vietnamese officials did not trust the persuaders, the nature of deliberation or consensus based decision-making did not help make their arguments persuasive.

Empirical findings in the Vietnam case also suggest that an agent's noviceness as a condition for socialization needs to be further studied. Even though the Vietnamese participants were genuine novices in PD and RtoP deliberations, noviceness at different points of time and contexts seems to embody different attributes and thus can facilitate socialization to different degrees. In other words, noviceness is contextual. The main similarity between Vietnamese

${ }^{550}$ Zurn and Checkel, "Getting Socialized to Build Bridges,"1047. 
officials as novices at the ARF in 2001 and those at the UNSC in 2008-2009 is that they all entered the deliberations with concerns about external intervention: preventive diplomacy, human rights and the RtoP all challenged Vietnam's longupheld norms of sovereignty and non-interference; supporting these norms required relaxation of traditional understanding of the two fundamental principles guiding state behaviour.

The main differences between them are on the level of independence in relation to their principals and openness to new information or issues. Although it seems that Vietnamese officials in New York did not enjoy much autonomy because they had to follow the strict reporting and coordinating rules and fixed guiding principles of conducting activities at the UNSC, they were actually in a more advantageous position in providing policy recommendations because no one else had a better understanding of the debates at the UNSC than they did. Therefore, almost all decisions on how Vietnam should vote at the Council were based on reports and recommendations from the mission in New York. In contrast, any steps that Vietnamese officials could take during ARF deliberations required instructions from MOFA leaders at home.

Vietnamese officials in New York were also more open to the new environment and issues at the UNSC. On the one hand, openness reflects the proactive posture on the part of the Vietnamese officials which is primarily driven by image concerns as shown in chapter six. On the other hand, openness is required by learning. A lack of understanding about RtoP forced the Vietnamese officials in New York to learn more about it as a concept so as to be capable of participating in the discussions and resolutions of RtoP-related issues. In addition, learning by doing whereby Vietnamese officials were directly involved in the resolution of RtoP situations like Sierra Leone provided them with more evidence of the necessity of RtoP's implementation. As a result, a new understanding of RtoP as a less threatening concept was developed and the moral significance embodied was recognized. 
Learning is, therefore, an attribute of noviceness and an independent causal mechanism. As a mechanism, learning in the Vietnam case should be understood as a process through which the Vietnamese officials used new information gaining from deliberations and discussions to update their beliefs and to devise actions that were consistent with those new beliefs. ${ }^{551}$ As was shown in chapter six, Vietnamese officials entered the RtoP deliberations and discussions without a clear understanding of the concept or prior preferences. Rather, engaging in deliberations helped state officials build the country's position on the issue.

\section{Beyond 2010: The new strategy of international integration}

The XI National Congress of the CPV in 2011 marked a new turn in Vietnam's integration process: the objectives and guidelines for the country's integration adopted at the X National Congress in 2006 - "proactively and actively engage in international economic integration while expanding international cooperation in other fields" - was transformed into "proactively and actively engage in international integration." "552 Vietnam is now determined to pursue a more comprehensive integration strategy that will not be limited to economics and trade, but which will also include security, national defence, social and cultural policy. ${ }^{553}$ Internal debates after the XI National Congress of the CPV

\footnotetext{
${ }^{551}$ Learning also occurred when Vietnam prepared to join ASEAN in the early 1990s. Through interactions Vietnam found many similarities with ASEAN countries that enabled VietnamASEAN cooperation which eventually led to the decision to join ASEAN. See Nguyen Vu Tung, "Vietnam's Membership in ASEAN: A Constructivist Interpretation," Contemporary Southeast Asia 29, no. 3 (2007): 483-505.

552 "Documents of the eleventh Congress of the Communist Party of Vietnam," the Communist Party of Vietnam, 2011,

http://chinhphu.vn/portal/page/portal/chinhphu/NuocCHXHCNVietNam/ThongTinTongHop/noid ungvankiendaihoidang?categoryId=10000716\&articleId=10038382. (Emphasis added).

${ }^{553}$ See Phạm Gia Khiêm, "Thực hiện chiến lược ngoại giao toàn diện hướng tới thực hiện thành công định hướng đối ngoại của Đại hội XI" [Carrying out the Strategy of Comprehensive Diplomacy toward the Successful Implementation of Foreign Policy Orientation of the XI Congress of the CPV], in Định huoóng Chính sách Đối ngoại Việt Nam trong giai đoạn mói [Vietnam's foreign policy orientation in the new period], ed. Phạm Bình Minh (Hanoi: Nhà Xuất bản Chính trị Quốc gia, 2011), 7-59.
} 
have focused on reviewing the country's integration process over the past decades and exploring foundations and substance of integration in security and national defence, social and culture up to the year $2020 .^{554}$ The theory and practice of international integration, especially in political, security and defence areas, have been explored and incorporated into a new Politburo Resolution on international integration. $^{555}$

Against this background, future research on how socialization has redefined Vietnam's interests and behaviour should continue to focus on high politics issues, particularly in the fields of security and defence which have long been the most sensitive and closed areas of cooperation. Conducting new investigations on how far Vietnam could go as a result of socialization - in addition to the adoption and internalization of norms - in security and defence cooperation is of great significance and relevance for the following reasons:

First, and in relation to the protection of national security and defence, Documents of the XI National Congress of the CPV for the first time clarify that the security aspect in the task of external relations activities is to "firmly protect independence, sovereignty, unification and territorial integrity." ${ }^{256}$ This new development reflects the increased concerns and awareness of threats to national security among policy-makers in Hanoi prior to and during the preparations for

\footnotetext{
${ }^{554}$ MOFA Foreign Policy Department Research Project "On Exploring Foundations of the Vietnamese Diplomacy in the early Decades of the $21^{\text {st }}$ Century," (2011); The Diplomatic Academy of Vietnam in May 2012 organized three workshops on international integration. The first workshop was on "Concepts, Substance, Objectives, and Guidelines on Vietnam's International Integration up to 2020," the second on "A comprehensive Review of Vietnam's International Integration over the past years," and the third on "International Integration: Orientations and Tasks on Integration in Security and National Defence, Social and Culture to the year 2020."

555 “The Politburo Resolution no. 22-NQ/TW on International Integration," dated April 10, 2013, http://www.mofahcm.gov.vn/mofa/bng_vietnam/nr080212094156/ns130709211917. More than one decade ago, on November 27, 2001the Politburo issued the Resolution on International Economic Integration, no. 07-NQ/TW.

${ }^{556}$ The main tasks as identified in the previous Documents and restated in the XI Documents consist of solid preservation of a peaceful environment which is conducive to the acceleration of national industrialization and modernization; and actively contributing to the common struggle of the world people for peace, national independence, democracy and social progress.
} 
the XI National Congress. Indeed, since 2007 territorial disputes in the East Sea (South China Sea) have become salient in Vietnam's external relations. The 2009 White Paper on National Defence by the Ministry of Defence specified threats to Vietnam's security and development, including among others the complicated developments concerning the disputes over sovereignty, sovereign rights and jurisdiction over the territories in the East Sea which have seriously affected the maritime economic development of Vietnam. ${ }^{557}$

The task of defending sovereignty and territorial integrity has therefore become more urgent. At the $17^{\text {th }}$ ARF in 2010, Vietnam in the Chairmanship of ASEAN showed for the first time a new preference for multilateral solutions in addition to the traditional bilateral ones concerning the sovereignty disputes in the East Sea. ${ }^{558}$ Vietnam successfully internationalized the disputes in the East Sea by getting the US to raise its voice, stressing its national interests in freedom of navigation, open access to Asia's maritime commons and support for multilateral negotiations to settle the territorial disputes. ${ }^{559}$ The CPV's leaders at the XI National Congress restated the need "to continue to expand external relations in the field of security and national defence," particularly "to participate in political and security mechanisms at bilateral and multilateral level on the basis of respect for fundamental principles as provided for in international law and the UN Charter..., 560

\footnotetext{
557 "Sách trắng Quốc phòng Việt Nam năm 2009" [National Defence White Paper 2009], Ministry of National Defence, accessed January 8, 2013, http://mod.gov.vn.

${ }^{558}$ The most recent bilateral agreement between Vietnam and China on the resolution of maritime issues was signed during the visit to China by Secretary-General Nguyen Phu Trong in 2011. See, "Việt-Trung ký thỏa thuận nguyên tắc giải quyết vấn đề Biển Đông" [Agreement on the Guiding Principles on the Resolution of Maritime Issues between Vietnam and China], VietnamNet, October 11, 2011, http://vietnamnet.vn/vn/chinh-tri/43226/viet-trung-ky-thoa-thuan-nguyen-tacgiai-quyet-van-de-bien-dong.html.

559 "Remarks by Secretary Clinton," US Department of State, July 23, 2010, http://www.state.gov/secretary/rm/2010/07/145095.htm.

560 "Documents of the XI National Congress of the CPV," the Communist Party of Vietnam, 2011, http:// http://chinhphu.vn/portal/page/portal/chinhphu/trangchu.
} 
In addition, the Documents of the XI National Congress of the CPV also added a new principle in the resolution of the remaining issues concerning borders, territory, maritime boundaries and continental shelf that is based on "regional norms." With these guidelines, Vietnam attaches greater importance to participation in political and security mechanisms, taking seriously regional norms and implying possible engagement in more substantive security and defence cooperation projects in response to security uncertainties. Most recently, integration in security and defence together with integration in other areas is defined as a means in order to achieve the two main objectives: (i) creating favourable conditions for economic integration; and (ii) taking the advantage of international resources and comparative advantages gained from international cooperation to effectively fulfil the task of defending the homeland. ${ }^{561}$

Second, the Documents of the XI National Congress also attach greater importance to multilateral diplomacy than in those of the previous Congresses. For example, Documents of the IX National Congress in 2001 aimed "to promote multi-directional relationships with developed countries and international organizations and to increase participation in multilateral forums." ${ }^{, 562}$ Documents of the X National Congress in 2006 stressed "the promotion of the comprehensive and effective relationships with ASEAN members and countries in Asia-Pacific region." ${ }^{563}$ The XI National Congress in 2011 has adopted a new orientation of participation in international organizations that put a great deal of emphasis on the implementation of Vietnam's obligations as a member toward achieving the goals of those institutions. The Documents read:

\footnotetext{
${ }^{561}$ MOFA Foreign Policy Department, "Overview Report on the Ministry-level Research Project on International Integration toward the Implementation of the Foreign Policy Orientation adopted at the XIth National Congress of the CPV," (2012), p. 50.

562 "Documents of the ninth Congress of the Communist Party of Vietnam," the Communist Party of Vietnam, 2001, hhtp://chinhphu.vn.

563 "Documents of the tenth Congress of the Communist Party of Vietnam."
} 
"to effectively fulfil obligations at international organizations, particularly at the United Nations; to pro-actively work and cooperate with countries, regional and international organizations in responding to non-traditional security challenges, especially climate change; to stand ready for dialogues with concerned countries, regional and international organizations on democracy and human rights issues;", 564

The same spirit is also found in the ASEAN cooperation framework, in which Vietnam-ASEAN relationship has been taken to a new height:

...To work with other ASEAN members in a pro-active and responsible manner toward building a strong ASEAN Community, strengthening relations with partners, maintaining an important role in cooperative mechanisms in Asia-Pacific region... ${ }^{565}$

With this new orientation, participation in ASEAN has now become "one of the pillars in Vietnamese foreign policy" and the "Vietnam-ASEAN relationship is now attached equal importance with the traditional, cooperative and friendship relationships between Vietnam and neighbouring countries with shared borders." 566 Therefore, it is more likely that from now until 2020, Vietnam's involvement in international institutions will be pursued in a more systemic and substantive manner.

Third, and related, is that the increased awareness of the importance of international institutions in Vietnamese foreign policy and the determination to actively work for the shared goals of these institutions are clearly signs of identity change on the part of the Vietnamese after exposure to institutional environments. ASEAN is a case in point. By making more commitments to the building of the

\footnotetext{
564 "Documents of the eleventh Congress of the Communist Party of Vietnam," the Communist Party of Vietnam, 2011, http://chinhphu.vn.

565 "Documents of the eleventh Congress of the Communist Party of Vietnam."

${ }^{566}$ Phạm Bình Minh, "Đường lối, chính sách đối ngoại của Việt Nam trong giai đoạn mới" [Foreign affairs guidelines and policies of Vietnam in the new stage of development], Tap chí Cộng sản 823 (2011): 35-39.
} 
ASEAN Community, Vietnam is showing an increased sense of belonging and a greater identification with the group. It now finds itself obliged, together with other ASEAN members, to work to achieve the shared goal of building ASEAN into a strong community, while at the same time wanting to preserve its important role in wider-regional cooperative mechanisms in the Asia-Pacific. Change in perception whereby Vietnam takes seriously the implementation of its membership obligations toward achieving shared goals in ASEAN has been a demonstration of the convergence of national interests with those of the regional institution on the one hand. On the other hand, it is a reflection of what constructivist scholars describe as change in the purposive content of identity that Vietnam is contributing to the construction of a collective identity of ASEAN. ${ }^{567}$

In short, some important changes can be identified concerning Vietnam's cooperation in the security and defence areas: (i) Vietnam's security interests have been redefined whereby they are now very closely aligned with those of the wider region; (ii) a new preference has been created as reflected in the sovereignty disputes in the East Sea that Vietnam now looks for both bilateral and multilateral solutions to the disputes; and (iii) Vietnam has become more identified with international institutions in general and political and security institutions in particular. These signs of change in identity, interests and behaviour appear to support constructivist arguments for change as a result of interactions within institutional environments.

For these reasons, socialization will be a relevant theoretical framework for investigating Vietnam's security and defence cooperation in the immediate future. It could be asked: has socialization led to changes in Vietnam's interests and behaviour in security and defence cooperation? If so, what new security norms and practices might Vietnam be expected to adopt and engage? Investigations along these lines should target defence and military officials because they are still

${ }^{567}$ Rawi Abdelal, Yoshiko M. Herrera, Alistair Iain Johnston, and Rose McDermott, "Identity as a Variable," Perspectives on Politics 4 (2006): 695-711. 
the most conservative group in foreign policy making circles and their involvement in international institutions are limited. Sites for testing socialization effects could begin with existing multilateral security and defence institutions in the region such as the ASEAN Political and Security Community (APSC); ASEAN Defence Ministers Meetings (ADMM) which came into being in 2006 and ADMM Plus which convened the first meeting in 2010; and the ASEAN Regional Forum. The reason is that Vietnam's new orientation in security and defence cooperation is in line with the development trajectory of these institutions that is toward more practical cooperation. ${ }^{568}$ This new orientation is articulated in the most recent Politburo Resolution on integration:

Proactively participating in multilateral institutions on security and national defence cooperation that Vietnam belongs to, first and foremost in the framework of ASEAN-led institutions; carrying out plans to join other multilateral institutions; taking part in cooperative activities in a more substantial manner such as participating in UN peacekeeping operations, WMD control activities, joint-military exercises and other activities, with a view to meeting the demands of the task of defending the homeland and making a contribution to deepening, stabilizing and consolidating of relationships with partners. ${ }^{569}$

Therefore, it seems likely that Vietnam will go beyond the adoption of norms and mere participation in security and defence dialogues to engage in more substantive practices and cooperative schemes. Given the salience of security challenges brought on by the territorial disputes in the East Sea, it will be particularly important to explore what specific security norms and practices and cooperative measures Vietnam might adopt and engage in to prevent and resolve conflicts in this hotspot.

\footnotetext{
568 “ASEAN Defence Ministers’ Meeting Three-Year Work Program 2011-2013,” ASEAN, accessed January 15, 2013, http://www.asean.org/archive/documents/18471-i.pdf.

569 “The Politburo Resolution no. 22-NQ/TW on International Integration,”, p. 4
} 
Conducting new research on Vietnam's security and defence cooperation within the framework of multilateral security institutions would therefore be of great relevance in a context in which Vietnam is pushing ahead with its international integration. Furthermore, if the internalization of norms investigated in this thesis characterizes the first phase of the country's integration process, so a new research project on Vietnam's cooperation in security and national defence along socialization lines would help shed light on how Vietnam might go beyond verbal support for norms to implement commitments in practice. This is of great significance because as stated in the new Politburo Resolution on international integration, "serious implementation of international commitments that Vietnam has made" ${ }^{570}$ is one among the guiding principles of the country's next phase of integration.

${ }^{570}$ Ibid., p.3. 


\section{BIBLIOGRAPHY}

\section{BOOKS AND MONOGRAPHS}

Acharya, Amitav. Constructing a Security Community in Southeast Asia: ASEAN and the Problem of Regional Order. $2^{\text {nd }}$ edition. London: Routledge, 2009.

—."Theoretical Perspectives on International Relations in Asia." In International Relations of Asia, edited by David Shambaugh and Michael Yahuda, 57-82. Maryland: Rowman \& Littlefield Publishers, 2008.

Acharya, Amitav, and Alastair Iain Johnston. Crafting Cooperation: Regional International Institutions in Comparative Perspective. Cambridge: Cambridge University Press, 2007.

Adler, Emanuel. "Constructivism and International Relations." In Handbook of International Relations, edited by Walter Carlsnaes, Thomas Risse and Beth A. Simmons, 95-118. London: SAGE, 2002.

Ba, Alice D. (Re)Negotiating East and Southeast Asia: Region, Regionalism, and the Association of Southeast Asian Nations. Stanford, Calif: Stanford University Press, 2009.

Bailey, Sydney D., and Sam Daws. The Procedure of the UN Security Council. Oxford: Oxford University Press, 1998.

Bennett, Andrew. "Process Tracing: A Bayesian Perspective." In The Oxford Handbook of Political Methodology, edited by Janet M. BoxSteffensmeier, Henry E. Brady and David Collier, 702-21. Oxford; New York: Oxford University Press, 2008.

Bolton, Kent. "Domestic Sources of Vietnam's Foreign Policy." In Vietnamese Foreign Policy in Transition, edited by Carlyle A. Thayer and Ramses Amer, 170-201. Singapore: Seng Lee Press Pte Ltd, 1999.

Burchill, Scott et al., Theories of International Relations. Basingstoke, Hampshire [U.K.]; New York Palgrave Macmillan, 2008. 
Bwa, Aung. "The Jewel in My Crown." In The Making of the ASEAN Charter, edited by Tommy Koh, Rosario G. Manalo and Walter Woon, 27-36. Singapore; Hackensack, NJ: World Scientific Pub. Co., 2009.

Anthony, Caballero M. Regional Security in Southeast Asia: Beyond the ASEAN Way. Singapore: Institute of Southeast Asian Studies, 2005.

Capie, David, and Paul Evans. The Asia-Pacific Security Lexicon. Singapore Institute of Southeast Asian Studies, 2007.

Christie, Kenneth, and Denny Roy. The Politics of Human Rights in East Asia. London; Sterling, Va.: Pluto Press, 2001.

Djani, Dian Triansyah. "A Long Journey." In The Making of the ASEAN Charter, edited by Tommy Koh, Rosario G. Manalo and Walter Woon, 137-50. Singapore; Hackensack, NJ: World Scientific Pub. Co., 2009.

Dosch, Jorn. The Changing Dynamics of Southeast Asian Politics. Boulder, Colo.: Lynne Rienner Publishers, 2007.

Eldridge, Philip J. The Politics of Human Rights in Southeast Asia. London; New York: Routledge, 2002.

Elliott, David W.P. Changing Worlds: Vietnam's Transition from Cold War to Globalization. New York: Oxford University Press, 2012.

Fearon, James, and Alexander Wendt. "Rationalism v. Constructivism: A Sceptical View." In Handbook of International Relations, edited by Walter Carlsnaes, Thomas Risse and Beth A. Simmons, 52-72. London: SAGE, 2002.

Finnemore, Martha. National Interests in International Society. Ithaca, N.Y.: Cornell University Press, 1996.

Foong, Khong Yuen, and Helen E.S. Nesadurai. "Hanging Together, Institutional Design, and Cooperation in Southeast Asia: AFTA and the ARF." In Crafting Cooperation: Regional International Institutions in Comparative Perspective, edited by Amitav Acharya and Alastair Iain Johnston, 32-82: Cambridge; New York: Cambridge University Press, 2007.

George, Alexander L., and Andrew Bennett. Case Studies and Theory Development in the Social Sciences. Cambridge, Mass.: MIT Press, 2004. 
Glosserman, Brad. "The United States and the ASEAN Regional Forum: A Delicate Balancing Act." In Cooperative Security in the Asia-Pacific: The ASEAN Regional Forum, edited by Jürgen Haacke and Noel M. Morada, 36-53. London; New York: Routledge, 2010.

Green, Michael J., and Bates Gill. Asia's New Multilateralism: Cooperation, Competition, and the Search for Community. New York: Columbia University Press, 2009.

Gschwend, Thomas, and Frank Schimmelfennig, eds. Research Design in Political Science: How to Practice What They Preach. Basingstoke [England]; New York: Palgrave Macmillan, 2007.

Guzzini, Stefano, and Anna Leander, eds. Constructivism and International Relations: Alexander Wendt and His Critics. New York, NY: Routledge, 2006.

Hashimoto, Hidetoshi. The Prospects for a Regional Human Rights Mechanism in East Asia. New York: Routledge, 2003.

Herrmann, Richard K. "Linking Theory to Evidence in International Relations." In Handbook of International Relations, edited by Walter Carlsnaes, Thomas Risse and Beth A. Simmons, 119-36. London: SAGE, 2002.

Hiro, Katsumata. ASEAN's Cooperative Security Enterprise: Norms and Interests in the ASEAN Regional Forum. Basingstoke [England]; New York: Palgrave Macmillan, 2009.

Hourn, Kao Kim. "A Personal Reflection." In The Making of the ASEAN Charter, edited by Tommy Koh, Rosario G. Manalo and Walter Woon, 151-58. Singapore; Hackensack, NJ: World Scientific Pub. Co., 2009.

Hughes, Christopher R. "China Membership of the ARF and the Emergence of an East Asian Diplomatic and Security Culture." In Cooperative Security in the Asia-Pacific: The ASEAN Regional Forum, edited by Jürgen Haacke and Noel M. Morada, 54-71. London; New York: Routledge, 2010.

Hulton, Susan C. "Council Working Methods and Procedure." In The UN Security Council: From the Cold War to the 21st Century, edited by David M. Malone, 237-51. Boulder, Colo. : Lynne Rienner, 2004.

Hurd, Ian. "Constructivism." In Oxford Handbook of International Relations, edited by Christian Reus-Smit and Duncan Snidal, 298-316. USA: Oxford University Press, 2010. 
Jervis, Robert. "Security Regimes." In International Regimes, edited by Stephen D. Krasner, 173-94. Ithaca: Cornell University Press, 1983.

Johnston, Alastair Iain. Social States: China in International Institutions 19802000. Princeton, N.J.: Princeton University Press, 2008.

Johnstone, Ian. "The Security Council as Legislature." In The UN Security Council and the Politics of International Authority, edited by Bruce Cronin and Ian Hurd, 80-104. London; New York: Routledge, 2008.

Keohane, Robert O. After Hegemony: Cooperation and Discord in the World Political Economy. Princeton, N.J.: Princeton University Press, 1984.

. International Institutions and State Power: Essays in International Relations Theory. Boulder: Westview Press, 1989.

Khong, Thi Binh, "China-Vietnam-Japan: A Strategic Triangle?" In Southeast Asia between China and Japan, edited by Lam Peng Er and Victor Teo, 123-142. Cambridge Scholars Publishing, 2012.

King, Gary, Robert O. Keohane, and Sidney Verba. Designing Social Inquiry: Scientific Inference in Qualitative Research. Princeton, N.J.: Princeton University Press, 1994.

Koh, Tommy. "The Negotiating Process." In The Making of the ASEAN Charter, edited by Tommy Koh, Rosario G. Manalo and Walter Woon, 47-68. Singapore; Hackensack, NJ: World Scientific Pub. Co., 2009.

Mahbubani, Kishore. "The Permanent and Elected Council Members." In The UN Security Council: From the Cold War to the 21st Century, edited by David M. Malone, 253-80. Boulder, Colo.: Lynne Rienner, 2004.

Martin, Lisa L., and Beth A. Simmons. "International Organization and Institutions." In Handbook of International Relations, edited by Walter Carlsnaes, Thomas Risse and Beth A. Simmons, 326-51. London: SAGE, 2013.

Morgenthau, Hans J. Politics among Nations: The Struggle for Power and Peace. New York: Knopf, 1973.

Nguyễn, Mạnh Cầm. "Quán triệt và Triển khai thực hiện Nghị quyết của Bộ Chính trị về Hội nhập Kinh tế Quốc tế [Understanding and implementation of the Politburo Resolution on international economic integration]." In 
Chính sách Đối ngoại Việt Nam: 1975-2006 [Vietnamese foreign policy, 1975-2006], edited by Nguyễn Vũ Tùng, 241-63. Hanoi: Học viện Quan hệ Quốc tế, 2007.

. "Trên đường triển khai Chính sách Đối ngoại theo định hướng mới [On the implementation of the new foreign policy]." In Chính sách Đối ngoại Việt Nam: 1975-2006 [Vietnamese foreign policy, 1975-2006], edited by Nguyễn Vũ Tùng, 205-19. Hanoi: Học viện Quan hệ Quốc tế, 2007.

Nguyen, Trung Thanh. "The Making of the ASEAN Charter in My Fresh Memories." In The Making of the ASEAN Charter, edited by Tommy Koh, Rosario G. Manalo and Walter Woon, 95-106. Singapore; Hackensack, NJ: World Scientific Pub. Co., 2009.

Nguyen, Vu Tung. "Testing the Institutionalist Approach: Cooperation between Vietnam and ASEAN." In Vietnam's New Order: International Perspective on the States and Reform in Vietnam, edited by Stephanie Balme and Mark Sidel, 51-70. New York: Palgrave Macmillan, 2007.

Palmujoki, Eero. "Vietnam's Integration into the World: National and Global Interfaces." In Vietnam's New Order: International Perspectives on the State and Reform in Vietnam, edited by Stephanie Balme and Mark Sidel, 119-33. New York: Palgrave Macmilan, 2007.

Patra, Pengiran Dato Paduka Osman. "Heart Labour." In The Making of the ASEAN Charter, edited by Tommy Koh, Rosario G. Manalo and Walter Woon, 1-17. Singapore; Hackensack, NJ: World Scientific Pub. Co., 2009.

Pattison, James. Humanitarian Intervention and the Responsibility to Protect: Who Should Intervene? Oxford: Oxford University Press, 2010.

Phạm, Gia Khiêm. "Thực hiện chiến lược ngoại giao toàn diện hướng tới thực hiện thành công định hướng đối ngoại của Đại hội XI" [Carrying out the Strategy of Comprehensive Diplomacy toward the Successful Implementation of Foreign Policy Orientation of the XI Congress of the CPV]. In Định huớng Chính sách Đối ngoại Việt Nam trong giai đoạn mói [Vietnam's foreign policy orientation in the new period], edited by Phạm Bình Minh, 7-59. Hanoi: Nhà Xuất bản Chính trị Quốc gia, 2011.

"Việt Nam tự tin bước trên con đường hội nhập" [Vietnam is confident on the road of integration]. In Chính sách Đối ngoại Việt Nam: 1975-2006 [Vietnamese foreign policy, 1975-2006], edited by Nguyễn Vũ Tùng, 22034. Hanoi: Học viện Quan hệ Quốc tế, 2007. 
Pibulsonggram, Pradap. "The Thai Perspective." In The Making of the ASEAN Charter, edited by Tommy Koh, Rosario G. Manalo and Walter Woon, 79-94. Singapore; Hackensack, NJ: World Scientific Pub. Co., 2009.

Razak, Tan Sri Ahmad Fuzi bin Abdul. "Facing Unfair Criticisms." In The Making of the ASEAN Charter, edited by Tommy Koh, Rosario G. Manalo and Walter Woon, 17-26. Singapore; Hackensack, NJ: World Scientific Pub. Co, 2009.

Risse, Thomas. "Constructivism and International Institutions: Toward Conversation Across Paradigms." In Political Science: State of the Discipline, edited by Ira Katznelson and Helen V. Milner, 597-623. New York: W. W. Norton \& Company, 2002.

Sansomak, Bounkeut. "A New Turning Point in the Relations among the Southeast Asian States." In The Making of the ASEAN Charter, edited by Tommy Koh, Rosario G. Manalo and Walter Woon, 159-66. Singapore; Hackensack, NJ: World Scientific Pub. Co., 2009.

Schimmelfening, Frank. "Strategic Calculation and International Socialization: Membership Incentives, Party Constellations, and Sustained Compliance in Central and Eastern Countries." In International Institutions and Socialization in Europe, edited by Jeffrey T. Checkel, 31-62. New York: Cambridge University Press, 2007.

Severino, Rodolfo C. The ASEAN Regional Forum. Singapore: Institute of Southeast Asian Studies, 2009.

Southeast Asia in Search of an ASEAN Community: Insights from the Former ASEAN Secretary-General. Singapore: Institute of Southeast Asian Studies, 2006.

Stein, Arthur A. "Neoliberal Institutionalism." In Oxford Handbook of International Relations, edited by Christian Reus-Smit and Duncan Snidal, 201-21. USA: Oxford University Press, 2010.

Sukma, Rizal. "The Accidental Driver: ASEAN in the ASEAN Regional Forum." In Cooperative Security in the Asia-Pacific: The ASEAN Regional Forum, edited by Jurgen Haacke and Noel M. Morada, 111-23. London; New York: Routledge, 2010.

Thayer, Carlyle A. "Vietnam's Regional Integration: Domestic and External Challenges to State Sovereignty." In Vietnam's New Order: International 
Perspectives on the State and Reform in Vietnam, edited by Stephanie Balme and Mark Sidel, 31-50. New York: Palgrave Macmilan, 2007.

."Vietnamese Foreign Policy: Multilateralism and the Threat of Peaceful Evolution." In Vietnamese Foreign Policy in Transition, edited by Carlyle A. Thayer and Ramses Amer, 1-43. Singapore: Seng Lee Press Pte Ltd, 1999.

Vennesson, Pascal. "Case Studies and Process Tracing: Theories and Practices." In Approaches and Methodologies in the Social Sciences: A Pluralist Perspective, edited by Donatella Della and Michael Keating Porta, 223-39: Cambridge: Cambridge University Press, 2008.

Vũ, Khoan. "Hội nhập và Phát triển" [Integration and Development]. In Chính sách Đối ngoại Việt Nam: 1975-2006 [Vietnamese foreign policy, 19752006], edited by Nguyễn Vũ Tùng, 235-40. Hanoi: Học viện Quan hệ Quốc tế, 2007.

. "Thành tựu trong lĩnh vực Đối ngoại qua 20 năm Đổi mới" [Achievements in external relations over 20 years of renovation]. In Chính sách Đối ngoại Việt Nam: 1975-2006 [Vietnamese foreign policy, 19752006], edited by Nguyễn Vũ Tùng, 425-44. Hanoi: Học viện Quan hệ Quốc tế, 2007.

Waltz, Kenneth N. Theory of International Politics. Reading, Mass.: AddisonWesley Pub. Co., 1979.

Weiss, Thomas G. Humanitarian Intervention: Ideas in Action. Cambridge; Malden, Mass.: Polity Press, 2007.

Weiss, Thomas G, and Ramesh Thakur. Global Governance and the UN: An Unfinished Journey. Bloomington: Indiana University Press, 2010.

Wendt, Alexander. Social Theory of International Politics. Cambridge: Cambridge University Press, 1999.

Wesley, Michael. "Membership Expansion and Change." In The Regional Organizations of the Asia Pacific: Exploring Institutional Change, edited by Michael Wesley, 97-116: Houndmills, Basingstoke, Hampshire; New York Palgrave Macmillan, 2003.

Yazuwa, Takeshi. Japan's Security Policy and the ASEAN Regional Forum: The Search for Multilateral Security in the Asia-Pacific. London; New York: Routledge, 2007. 
Yong, Ong Keng. "At Close Quarters with the Drafting of the ASEAN Charter." In The Making of the ASEAN Charter, edited by Tommy Koh, Rosario G. Manalo and Walter Woon, 107-16. Singapore; Hackensack, NJ: World Scientific Pub. Co., 2009.

\section{JOURNAL ARTICLES}

Abbott, Kenneth W., and Duncan Snidal. "Why States Act through Formal International Organizations." The Journal of Conflict Resolution 42, no. 1 (1998): 3-32.

Abdelal, Rawi, Yoshiko M. Herrera, Alastair Iain Johnston, and Rose McDermott. "Identity as a Variable." Perspectives on Politics 4, no. 4 (2006): 695-711.

Acharya, Amitav. "Ideas, Identity, and Institution-Building: From the 'ASEAN Way' to the 'Asia-Pacific Way'?" The Pacific Review 10, no. 3 (1997): 319-46.

Alexandra, Lina. "Indonesia and the Responsibility to Protect." The Pacific Review 25, no. 1 (2012): 51-74.

Amer, Ralf. "The Indochinese Enlargement of ASEAN: Security Expectation and Outcomes." Australian Journal of International Affairs 59, no. 1 (2005): 71-88.

Amer, Ramses. "Vietnam in 2009: Facing the Global Recession." Asian Survey 50, no. 1 (2010): 211-17.

—. "Vietnam in 2010." Asian Survey 51, no. 1 (2011): 196-201.

Anthony, Caballero. M. "The ASEAN Charter: An Opportunity Missed or One That Cannot Be Missed?" Southeast Asian Affairs (2008): 71-85.

Ba, Alice D. "Who's Socializing Whom? Complex Engagement in Sino-ASEAN Relations." The Pacific Review 19, no. 2 (2006): 157-79.

Barnett, Michael, and Raymond Duvall. "Power in International Politics." International Organization 59, no. 1 (2005): 39-75. 
Bellamy, Alex J. "Libya and the Responsibility to Protect: The Exception and the Norm." Ethics \& International Affairs 25, no. 3 (2011): 263-69.

"The Responsibility to Protect: Five Years On." Ethics and International Affairs 24, no. 2 (2010): 143-69.

"Wither the Responsibility to Protect? Humanitarian Intervention and the 2005 World Summit." Ethics and International Affairs 20, no. 2 (2006): 143-71.

Bellamy, Alex J., and Catherine Drummon. "The Responsibility to Protect in Southeast Asia: Between Non-Interference and Sovereignty as Responsibility." The Pacific Review 24, no. 2 (2011): 197-200.

Capie, David. "The Responsibility to Protect Norm in Southeast Asia: Framing, Resistance and the Localization Myth." The Pacific Review 25, no. 1 (2012): 75-93.

Checkel, Jeffrey T. "The Constructivist Turn in International Relations Theory." World Politics 50, no. 2 (1998): 324-48.

—. "International Institutions and Socialization in Europe: Introduction and Framework." International Organization 59, no. 4 (2005): 801-26.

—. "Why Comply? Social Learning and European Identity Change." International Organization 55, no. 3 (2001): 553-88.

Đặng, Đình Quý. "Bàn thêm về khái niệm và nội hàm hội nhập quốc tế của Việt Nam trong giai đoạn mới" [On the concepts and contents of Vietnam's international integration in the new period]." Nghiên cứu Quốc tế 91 (2012): 19-32.

."Nhìn lại năm năm sau gia nhập WTO: Một số tác động về đối ngoại và bài học đối với Việt Nam" [Vietnam's participation in the World Trade Organization after five years: Implications and lessons for the country's external relations], Nghiên cứu Quốc tế 88 (2012): 5-14.

Davies, Mathew. "ASEAN and Human Rights Norms: Constructivism, Rational Choice, and the Action-Identity Gap." International Relations of the AsiaPacific 13, no. 2 (2013): 207-31.

Dosch, Jorn. "ASEAN's Reluctant Liberal Turn and the Thorny Road to Democracy Promotion." The Pacific Review 21, no. 4 (2008): 527-45. 
—_."Vietnam's ASEAN Membership Revisited: Golden Opportunity or Golden Cage?" Contemporary Southeast Asia 28, no. 2 (2006): 234-58.

Duffield, John. "What Are International Institutions?" International Studies Review 9, no. 1 (2007): 1-22.

Dunne, Tim, and Jess Gifkins. "Libya and the State of Intervention." Australian Journal of International Affairs 65, no. 5 (2011): 515-29.

Eaton, Sarah, and Richard Stubbs. "Is ASEAN Powerful? Neo-Realist Versus Constructivist Approaches to Power in Southeast Asia." The Pacific Review 19, no. 2 (2006): 135-55.

Emmers, Ralf, and See Seng Tan. "The ASEAN Regional Forum and Preventive Diplomacy: Built to Fail?" Asian Security 7, no. 1 (2011): 44-60.

Emmerson, Donald K. "ASEAN's 'Black Swans'." Journal of Democracy 19, no. 3 (2008): 70-84.

Finnemore, Martha. "Norms, Culture and World Politics: Insights from Sociology's Institutionalism." International Organization 50, no. 2 (1996): 325-47.

Goh, Evelyn. "Institutions and the Great Power Bargain in East Asia: ASEAN's Limited 'Brokerage' Role." International Relations of the Asia-Pacific 11 (2011): 373-401.

Goldmann, Kjell. "Appropriateness and Consequences: The Logic of NeoInstitutionalism." Governance 18, no. 1 (2005): 35-52.

Grieco, Joseph M. "Anarchy and the Limits of Cooperation: A Realist Critique of the Newest Liberal Institutionalism." International Organization 42, no. 3 (1988): 485-507.

Haack, Jurgen. "The Concept of Flexible Engagement and the Practice of Enhanced Interaction." The Pacific Review 12, no. 4 (1999): 581-611.

Haas, Peter M., and Ernst B. Haas. "Pragmatic Constructivism and the Study of International Institutions." Journal of International Studies 31, no. 3 (2002): 573-601.

Hall, Peter A. "Policy Paradigms, Social Learning and the State: The Case of Economic Policy Making in Britain." Comparative Politics 25, no. 3 (1993): 275-96. 
Hao, Duy Phan. "The Evolution Towards an ASEAN Human Rights Body." AsiaPacific Journal on Human Rights \& the Law 9, no. 1 (2008): 1-12.

Hawkins, Darren. "Explaining Costly International Institutions: Persuasion and Enforceable Human Rights Norms." International Studies Quarterly 48, no. 4 (2004): 779-804.

Hopf, Ted. "The Promise of Constructivism in International Relations Theory." International Security 23, no. 1 (1998): 171-200.

Jervis, Robert. "Realism, Neoliberalism, and Cooperation: Understanding the Debate." International Security 24, no. 1 (1999): 42-63.

Johnston, Alastair Iain. "Conclusion and Extensions: Toward Mid-Range Theorizing and Beyond Europe." International Organization 59, no. 4 (2005): 1013-44.

."Treating International Institutions as Social Environments." International Studies Quarterly 45, no. 4 (2001): 487-515.

—. Learning Versus Adaptation: Explaining Change in Chinese Arms Control Policy in the 1980s and 1990s." The China Journal, no. 53 (1996): 27-61.

Jones, David Martin, and Michael L. R. Smith. "Making Process, Not Progress: ASEAN and the Evolving East Asian Regional Order." International Security 32, no. 1 (2007): 148-84.

Jones, Lee. "ASEAN's Unchanged Melody? The Theory and Practice of 'NonInterference' in Southeast Asia." The Pacific Review 23, no. 4 (2010): 479502 .

Kelley, Judith. "International Actors on the Domestic Scene: Membership Conditionality and Socialization by International Institutions." International Organization 58, no. 3 (2004): 425-57.

Keohane, Robert, and Lisa L. Martin. "The Promise of Institutionalist Theory." International Security 20, no. 1 (1995): 39-51.

Keohane, Robert O. "International Institutions: Can Interdependence Work?" Foreign Policy, no. 110 (1998): 82-94. 
Koremenos, Barbara, Charles Lipson, and Duncan Snidal. "The Rational Design of International Institutions." International Organization 55, no. 4 (2001): 761-99.

Kraisoraphong, Keokam. "Thailand and the Responsibility to Protect." The Pacific Review 25, no. 1 (2012): 1-25.

Manea, Maria-Gabriela. "Human Rights and the Interregional Dialogue between Asia and Europe: ASEAN-EU Relations and ASEM." The Pacific Review 21, no. 3 (2008): 369-96.

Martin, Lisa L. "Interests, Power, and Multilateralism." International Organization 46, no. 4 (1992): 765-92.

Martin, Lisa L., and Beth A. Simmons. "Theories and Empirical Studies of International Institutions." International Organization 52, no. 4 (1998): 729-57.

Mearsheimer, John J. "The False Promise of International Institutions." International Security 19, no. 3 (1994-1995): 5-49.

Moeller, Joergen Oerstromem. "ASEAN's Relations with the European Union: Obstacles and Opportunities." Contemporary Southeast Asia 29, no. 3 (2007): 465-82.

Mohamad, Maznah. "Toward a Human Rights Regime in Southeast Asia: Charting the Course of State Commitment." Contemporary Southeast Asia 24, no. 2 (2002): 230-51.

Munro, James. "Why States Create International Human Rights Mechanism: The ASEAN Intergovernmental Commission on Human Rights and Democratic Lock-in Theory." Asia - Pacific Journal on Human Rights \& the Law 10, no. 1 (2009): 1-26.

Narine, Shaun. "ASEAN in the Twenty-First Century: A Sceptical Review." Cambridge Review of International Affairs 22, no. 3 (2009): 369-86.

Nguyen, Manh Hung. "Vietnam in 1999: The Party Choice." Asian Survey 40, no. 1 (2000): 98-111.

"Vietnam: Facing the Challenge of Integration." Southeast Asian Affairs (2004): 297-311. 
Nguyen, Vu Tung. "Vietnam-ASEAN Co-operation after the Cold War and the Continued Search for a Theoretical Framework." Contemporary Southeast Asia 24, no. 1 (2002): 106-20.

_. "Vietnam's Membership of ASEAN: A Constructivist Interpretation." Contemporary Southeast Asia 29, no. 3 (2007): 483-505.

Palan, Ronen. "A World of Their Making: An Evaluation of the Constructivist Critique in International Relations." Review of International Studies 26, no. 4 (2000): 575-98.

Phạm, Bình Minh. "Chủ động và tích cực hội nhập quốc tế theo tinh thần nghị quyết Đại hội Đảng toàn quốc lần thứ XI" [Proactive international integration in line with the Resolution of the XIth National Congress of the Communist Party of Vietnam], Nghiên cưu Quốc tế 91 (2012): 5-18.

——. "Đường lối, chính sách đối ngoại của Việt Nam trong giai đoạn mới [Foreign affairs guidelines and policies of Vietnam in the new stage of development]." Tạp chí Cộng sản 823 (2011): 35-39.

Phạm, Gia Khiêm. "Đối ngoại Việt Nam năm 2007: Góp phần thiết thực cho sự nghiệp xây dựng và bảo vệ Tổ quốc xã hội chủ nghĩa" [Vietnam's external relations in 2007: Contribution to the cause of national construction and defence], Tạp chí Cộng sản 784 (2008): 17-23.

_ _ "Ngoại giao Việt Nam năm 2008 và định hướng năm 2009" [Foreign affairs of Vietnam in 2008 and orientation in 2009], Tap chí Cọng sản 796 (2009): 14-19.

. "Ngoại giao Việt Nam năm 2010: Vững bước trên con đường hội nhập và phát triển" [Foreign affairs of Vietnam in 2010: Steady advance on the path of integration and development], Tạp chí Cộng sản 819 (2011): 1420 .

"Việt Nam và nhiệm kỳ chủ tịch ASEAN 2010: Thành tựu của ASEAN và dấu ấn Việt Nam" [Vietnam as Chairman of ASEAN in 2010: Achievements of ASEAN and the Vietnamese imprint], Tạp chí Cộng sản 818 (2010): 8-15.

Phan, Doãn Nam. "Ngoại giao Việt Nam trong 25 năm Đổi mới: 1986-2010" [Vietnam's diplomacy 25 years since Doimoi: 1986-2010], Tạp chí Cộng sản 814 (2010): 42-46. 
Risse, Thomas. ""Let's Argue!": Communicative Action in World Politics." International Organization 54, no. 1 (2000): 1-39.

Rüland, Jürgen. "Southeast Asian Regionalism and Global Governance: 'Multilateral Utility' or 'Hedging Utility?" Contemporary Southeast Asia 33, no. 1 (2011): 83-112.

Selth, Andrew. "Even Paranoids Have Enemies: Cyclone Nargis and Myanmar's Fears of Invasion." Contemporary Southeast Asia 30, no. 3 (2008): 397402.

Severino, Rodolfo C. "ASEAN Beyond Forty: Towards Political and Economic Integration." Contemporary Southeast Asia 29, no. 3 (2007): 406-23.

Sidel, Mark. "Vietnam in 1998: Reform Confront the Regional Crisis." Asian Survey 39, no. 1 (1999): 89-98.

Snidal, Duncan. "Coordination Versus Prisoners' Dilemma: Implications for International Cooperation and Regimes." The American Political Science Review 79, no. 4 (1985): 923-42.

Stein, Arthur A. "Coordination and Collaboration: Regimes in an Anarchic World." International Organization 36, no. 2 (1982): 299-324.

Sterling-Folker, Jennifer. "Competing Paradigms or Birds of a Feather? Constructivism and Neoliberal Institutionalism Compared." International Studies Quarterly 44, no. 1 (2000): 97-119.

Tan, See Seng. "Herding Cats: The Role of Persuasion in Political Change and Continuity in the Association of Southeast Asian Nations (ASEAN)." International Relations of the Asia-Pacific 13, no. 2 (2013): 233-65.

Than, Tin Maung Maung. "Myanmar in 2008: Weathering the Storm." Southeast Asian Affairs (2009): 195-222.

Tiewa, Liu. "China and Responsibility to Protect: Maintenance and Change of Its Policy for Intervention." The Pacific Review 25, no. 1 (2012): 153-73.

Trương Đình Tuyển, “Tác động của việc gia nhập Tổ chức Thương mại Thế giới và hội nhập kinh tế quốc tế đến phát triển kinh tế-xã hội của Việt Nam: Một năm nhìn lại" [Review of the first year of WTO membership and international economic integration: Impacts on Vietnam's socio-economic development], Tạp chí Cộng sản 783 (2008): 52-56. 
Vuving, Alexander L. "Strategy and Evolution of Vietnam's China Policy: A Changing Mixture of Pathways." Asian Survey 46, no. 6 (2006): 805-24.

"Vietnam: Arriving in the World - and at a Crossroads." Southeast Asian Affairs (2008): 375-93.

Wah, Chin Kin. "Introduction: ASEAN Facing the Fifth Decade." Contemporary Southeast Asia 29, no. 3 (2007): 395-405.

Walker, R. B. J. "Realism, Change, and International Political Theory." International Studies Quarterly 31, no. 1 (1987): 65-86.

Waltz, Kenneth N. "Structural Realism after the Cold War." International Security 25, no. 1 (2000): 5-41.

Welsh, Jenifer. "Civilian Protection in Libya: Putting Coercion and Controversy Back into RtoP." Ethics \& International Affairs 25, no. 3 (2011): 255-62.

Wohlforth, William C. "Realism and the End of the Cold War." International Security 19, no. 3 (1994-1995): 91-129.

Yuzawa, Takeshi. "The Evolution of Preventive Diplomacy in the ASEAN Regional Forum: Problems and Prospects." Asian Survey 46, no. 5 (2006): 785-804.

Zachary, Abuza. "Institutions and Actions in Vietnamese Foreign Policymaking: A Research Note." Contemporary Southeast Asia 19 (1997): 309-33.

Zurn, Michael, and Jeffrey T. Checkel. "Getting Socialized to Build Bridges: Constructivism and Rationalism, Europe and the Nation-State." International Organizations 59, no. 4 (2005): 1045-79.

\section{OFFICIAL DOCUMENTS}

MOFA ASEAN Department. "Background Documents 'Aide Memoire on Three Papers prepared by Singapore, Japan and Republic of Korea by Australia High Commission Singapore dated January 29, 2001' prepared for the 2nd ISG-CBM, Kuala Lumpur, Malaysia, April15-20, 2001." 2001. -."PD Paper Circulated at Singapore ISG-CBM, April 5-7." 2001. 
. "Background Documents 'Canada's Written Comments on Singapore's Paper dated January 30, 2001' prepared for the 2nd ISG-CBM, Kuala Lumpur, Malaysia, April15-20, 2001." 2001.

"Background Documents 'China's Written Comments on Singapore's Paper dated January 9, 2001' prepared for the 2nd ISG-CBM, Kuala Lumpur, Malaysia, April15-20, 2001."." 2001.

"Background Documents 'US Comments on Singapore's Paper and Japan's Paper' prepared for the 2nd ISG-CBM, Kuala Lumpur, Malaysia, April15-20, 2001." 2001.

_. "Background Documents on the ARF." 2000.

—. "Background Documents on the ARF prepared for the 7th ARF." 2000.

—. "Cable Massage on the ISG-CBM, Soul, Korea, November 1-3, 2000." 2000.

- "Diplomatic Note by Singapore Ministry of Foreign Affairs dated February 24, 2001 sent to the Republic of Korea and Malaysia." 2001.

—. "Documents prepared for the 27th Diplomatic Conference." 2011.

_. "Memo on Preparation for the 2nd ISG-CBM." 2001.

- "Memo on Vietnam's Views on Singapore Discussion Paper (Paper Circulated at Singapore ISG-CBM April 5-7)." 2000.

- "Memo prepared for the First Meeting of the HLTF on Drafting ASEAN Charter." 3, 2007.

—. "On Chairing the 8th ARF." 5, 2001.

—. "On Chairing the AMM Retreat, Rangoon, Myanmar, April 30, 2001." 1, 2001.

—. "On One Year Vietnam Works as Co-Chair of the ARF ISG-CBM." 1, 2001.

—. "On Our Participation in the 33rd ASEAN Ministerial Meeting." 1-2, 2000. 
. "On Participation in the 2nd ISG-CBM in Malaysia, April 15-20, 2001." 3, 2001.

—

_. "On the Co-Chairmanship of the First ISG-CBM, New Delhi, December 19-21, 2001." 3, 2001.

—. "On the Contents of the 43rd AMM and Related Meetings." 2, 2010.

. "On the Results of the 35th AMM/the 9th ARF/PMC, Brunei from July 28 to August 1, 2002." 2002.

—. "On the Results of the Seventh Meeting of the High Level Task Force on the Drafting of the ASEAN Charter." 3, 2007.

—. "On Vietnam's Ten Year Participation in ASEAN." 11, 2005.

—. "Recommendations on Our Positions in Dealing with the Issue of the Establishment of ASEAN Human Rights Body in the ASEAN Charter in the Preparation for the Ninth HTLF Meeting on the Drafting of the ASEAN Charter." 4, 2007.

. "Report submitted to the Foreign Minister on Some Issues Relating to the ARF SOM in May 2001 in Hanoi." 2001.

—. "Research Project on the First Five Years of Vietnam's Participation in ASEAN: Achievements, Challenges and Prospects." 112, 2001.

"Research Project on the Prospects of ASEAN in the First Two Decades of the 21st Century: Implications and Vietnam's Strategy." 80, 2008.

_ "Talking Points and Documents prepared for the 7th and the 8th ARF." 2000.

—. "Talking Points for the 7th ARF on Measures of Overlap between CBMs and PD." 2, 2000.

. "Talking Points for the 7th RAF on Paper on the Concept and Principles of PD of Singapore." 2000.

. "Talking Points on Democracy and Human Rights prepared for the 33rd AMM." 2000. 
_. "Vietnam's Views on Japan’s Discussion Paper (Revised)." 2001.

MOFA Foreign Policy Department. "On the Draft of the Report on Updates on Situations in Libya and Other Countries in Middle East and North Africa." 2011.

- "Overview Report on the Ministry-Level Research Project on International Integration toward the Implementation of the Foreign Policy Orientation adopted at the XIth National Congress of the CPV." 25, 2012.

- "Research Project on Exploring Foundations of the Vietnamese Diplomacy in the Early Decades of the 21st Century." 2011.

MOFA West Asia and African Department. "On Political Upheavals in the Middle East and North Africa: Situations, Causes and Implications." 2011.

MOFA Department of International Organizations. "Cable Message No. 545/HT dated December 27, 2009." 2009.

. "On Our Second Presidency of the UN Security Council in October 2009." 2009.

- "On the Council's Procedural Voting on the Format of the Meeting on Zimbabwe." 2, 2008.

__. "On the Exchange of Views with Chinese Second Secretary." 2008.

—_. "On the UNSC's Activities and Vietnam's Participation in April 2008." 2008.

-. "On the UNSC's Activities and Vietnam's Participation in May 2008." 5 , 2008.

. "Our Position on the Security Council's Draft Resolution on Zimbabwe." 2008.

—. "Presentation at the 26th Diplomatic Conference 'Some Initial Thoughts on the Increased Participation in the Process of International Cooperation toward the Implementation of Vietnamese Foreign Policy set out since the Xth National Congress of the CPV and One Year as Non-Permanent Member of the UNSC'." 4, 2008.

. "Proposal on the Bid for a Non-Permanent Membership at the UNSC." 1997. 
—. "Research Project on the Issue of Democracy and Human Rights in International Relations and in Vietnam's External Relations." 67, 2003.

—. "Research Project on Vietnam and Its First Non-Permanent Membership at the UNSC (2008-09): Experiences and Lessons." 58, 2012.

_. "Vietnam Assumes the 2nd UN Security Council Presidency in October 2009." 2, 2009.

-."Our Position on the Security Council's Draft Resolution on Zimbabwe." 4, 2008.

Participation." 98, 2005.

The ASEAN Secretariat. "ASEAN Secretary-General's Summary on Decisions of ASEAN Foreign Ministers on the First Draft of ASEAN Charter." 2007.

"Decisions of the ASEAN Foreign Ministers on the Third Progress Report of the High Level Task Force (HLTF) on the Drafting of the ASEAN Charter." 2007.

- "Record of the 2nd Meeting of the High Level Task Force on the Drafting of the ASEAN Charter." 2007.

the ASEAN Charter." 26, 2007.

- "Record of the 12th Meeting of the High Level Task Force on the Drafting of the ASEAN Charter." 2007.

—. "Record of the Eighth Meeting of the High Level Task Force on the Drafting of the ASEAN Charter." 2007.

—. "Record of the Seventh Meeting of the High Level Task Force on the Drafting of the ASEAN Charter." 2007.

- "Record of the Third Meeting of the High Level Task Force on the Drafting of the ASEAN Charter." 2007.

—. "Secretary-General Summary from the AMM Retreat." 2007. 
The Diplomatic Academy of Vietnam. "On the Establishment of the ASEAN Human Rights Body and Vietnam's Policy." 80, 2008.

\section{ONLINE SOURCES}

Acharya, Amitav. "Asian Regional Institutions and the Possibilities for Socializing the Behaviour of States." ADB Working Paper, Asian Development Bank, 2011. http://www.adb.org/publications/asian-regionalinstitutions-and-possibilities-socializing-behavior-states

Ministry of Foreign Affairs. "White Book on Vietnam's Achievements in the Protection and Promotion of Human Rights." 2005. http://www.mofa.gov.vn/en/ctc_quocte/ptklk/nr040819162124/ns0702061 02551.

."Interview with Ambassador Le Luong Minh by a Vietnam News Agency Correspondent on Vietnam's Activities during Its Presidency." Accessed October 12, 2012.

http://www.mofahcm.gov.vn/vi/mofa/cs_doingoai/nr070523093001/ns080 801135812 .

ASEAN. "ASEAN Political-Security Community Blueprint." June 2009. http://www.asean.org/archive/5187-18.pdf.

. "The ASEAN Regional Forum: A Concept Paper." August 1, 1995, http://aseanregionalforum.asean.org/files/library/

"ASEAN-UN International Pledging Conference on Cyclone Nargis." May 25, 2008. http://www.aseansec.org/21569.htm.

—. "Chairman's Statement of the 11th ASEAN Summit." December 12, 2005. http://www.aseansec.org/18039.htm.

—_. "Declaration of ASEAN Concord II." October 7, 2003. http://www.aseansec.org/15669.htm.

"Hanoi Plan of Action." December 15-16, 1998, http://www.asean.org/8754.htm

- "Joint Communiqué of the Twenty-Sixth ASEAN Ministerial Meeting." July 23-24, 1993. http://www.asean.org/communities/asean-political- 
security-community/item/joint-communique-of-the-twenty-sixth-aseanministerial-meeting-singapore-23-24-july-1993

"Master Plan of ASEAN Connectivity." December 2010. http://www.asean.org/archive/documents/MPAC.pdf.

. "Report of the Eminent Persons Group on the ASEAN Charter." Accessed September 10, 2012. http://www.aseansec.org/19247.pdf

_ . "Vientiane Action Programme." November 29, 2004. http://www.aseansec.org/ADS-2004.pdf.

Ministry of National Defence. "Sách trắng Quốc phòng Việt Nam năm 2009 [National Defence White Paper 2009]." Accessed January 8, 2013, http://www.mod.gov.vn/wps/wcm/connect/e1c352c1-0fb5-4107-8642ae500e70dd7b/2009vie.pdf?MOD=AJPERES\&CACHEID=e1c352c10fb5-4107-8642-ae500e70dd7b.

Asia Pacific Forum. "Cambodia Set out Path to the National Human Rights Institution." Accessed May 23, 2012, http://www.asiapacificforum.net/news/cambodia-sets-out-path-toestablish-nhri.html

ASEAN Regional Forum. "Chairman's Statement of the Eighth Meeting of the ASEAN Regional Forum." July 25, 2001.

http://aseanregionalforum.asean.org/library/arf-chairmans-statements-andreports.html.

. "Co-Chairmen's Summary Report of the Meeting of the ARF InterSessional Support Group (ISG) on Confidence Building Measures." November 1-3, 2000 \& April 18-20, 2001, http://aseanregionalforum.asean.org/library/arf-chairmans-statements-andreports/162.html.

"Co-Chairmen's Summary Report of the Meetings of the ARF InterSessional Support Group on Confidence Building Measures." November 4-6, 1997 \& March 4-6, 1998. http://www.asean.org/archive/arf/5ARF/ISG-CBM-BSBSydney/Report.pdf.

. "Co-Chairmen's Summary Report of the Meetings of the ARF InterSessional Support Group on Confidence Building Measures." November 4-6, 1997 \& March 4-6, 1998. 
http://aseanregionalforum.asean.org/library/arf-chairmans-statements-andreports/156.html.

"Co-Chairmen's Summary Report of the Meetings of the AFR InterSessional Support Group on Confidence Building Measures." December 19-21, 2001 \& April 22-24, 2002.

http://aseanregionalforum.asean.org/library/arf-chairmans-statements-andreports/165.html.

. "Hanoi Plan of Action to Implement the ASEAN Regional Forum Vision Statement." May 20, 2010. http://aseanregionalforum.asean.org/library/arfchairmans-statements-and-reports.html.

—. "Singapore Declaration on the 15th ARF." July 24, 2008.

http://aseanregionalforum.asean.org/library/arf-chairmans-statements-andreports.html

Minh Khôi. "Việt Nam ứng cử Hội đồng Nhân quyền Liên Hợp Quốc: Vì một thế giới Hòa bình, Thịnh vượng và Công bằng [Vietnam Bids for Membership at the UN Human Rights Council: Striving for a World of Peace, Prosperity and Equality]." Thế giới và Việt Nam. March 9, 2011. http://www.baomoi.com/Home/DoiNoiDoiNgoai/www.tgvn.com.vn/Viet-Nam-ung-cu-Hoi-dong-Nhan-quyenLHQ-Vi-mot-the-gioi-hoa-binh-thinh-vuong-cong-bang/5838581.epi

Lê, Minh. "Về cái gọi là can thiệp nhân đạo" [On the so-called humanitarian intervention]. Tạp chí Cộng sản Online. August 28, 2008, http://www.tapchicongsan.org.vn/Home/PrintStory.aspx?distribution=266 $5 \&$ print $=$ true

Minh Thức. "Việt Nam sẵn sàng tham gia Lực lượng gìn giữ hòa bình Liên Hợp Quốc" [Vietnam Prepared to Join UN Peace Keeping Forces]. Thanh Niên Online. November 17, 2012.

http://www.thanhnien.com.vn/pages/20121116/viet-nam-chuan-bi-thamgia-luc-luong-gin-giu-hoa-binh-lhq.aspx.

"Phát biểu của Thủ Tướng Nguyễn Tấn Dũng nhân Ngày ASEAN." Thế giới và Việt Nam. August 7, 2012.

http://tgvn.com.vn/Item/VN/ChinhTri/2012/8/9A8441E6138B7A5E/.

"Việt-Trung ký thỏa thuận nguyên tắc giải quyết vấn đề Biển Đông” [Agreement on the Guiding Principles on the Resolution of Maritime Issues between Vietnam and China]. VietnamNet. October 11, 2011. 
http://vietnamnet.vn/vn/chinh-tri/43226/viet-trung-ky-thoa-thuan-nguyentac-giai-quyet-van-de-bien-dong.html.

Permanent Mission of the Socialist Republic of Vietnam to the United Nations.

"Address by H.E. Pham Gia Khiem, Deputy Prime Minister and Minister of Foreign Affairs at the Open Debate of the UN Security Council on 'Women and Peace and Security'." October 5, 2009. http://www.vietnamun.org/en/vnun.php?id=158\&cid=1.

"Statement by H.E Mr. Pham Gia Khiem, Deputy Prime Minister and Minister of Foreign Affairs at the United Nations Security Council Open Debate on 'Children and Armed Conflict'." October 5, 2009.

http://www.vietnam-un.org/en/vnun.php?id=80\&cid=1.

. "Statement by H.E. Ambassador Bui The Giang, Deputy Permanent Representative of Viet Nam at the Security Council Open Debate on Children and Armed Conflict." April 29, 2009. http://www.vietnamun.org/en/vnun.php?id=134\&cid=1.

. "Statement by H.E. Ambassador Bui The Giang, Deputy Permanent Representative of Viet Nam, at the General Assembly Plenary Meeting on Responsibility to Protect (R2P)." July 24, 2009. http://www.vietnamun.org/en/vnun.php?id=151\&cid=23.

. "Statement by H.E. Ambassador Bui The Giang, Deputy Permanent Representative of Viet Nam, at the Security Council Open Debate on Protection of Civilians in Armed Conflict." June 26, 2009.

http://www.vietnam-un.org/en/vnun.php?id=145\&cid=1 .

. "Statement by H.E. Ambassador Mr. Bui The Giang, Deputy Permanent Representative at Open Debate on Protection of Civilians in Armed Conflict." May 27, 2008. http://www.vietnamun.org/en/vnun.php?id=67\&cid=1.

The United Nations. "The 90th Plenary Meeting of the General Assembly." April 8, 2005. http://daccess-ddsny.un.org/doc/UNDOC/GEN/N05/301/15/PDF/N0530115.pdf?OpenElem ent.

"Draft Resolution on Zimbabwe." July 11, 2008. http://www.securitycouncilreport.org/atf/cf/\%7B65BFCF9B-6D27-4E9C8CD3-CF6E4FF96FF9\%7D/POC\%20S2008447.pdf 
. "In Large Freedom: Towards Development, Security and Human Rights for All." March 21, 2005, http://www.un.org/largerfreedom/.

. "Letter Dated 30 December 2008 from the Permanent Representative of South Africa to the United Nations Addressed to the President of the Security Council." December 31, 2008.

http://www.refworld.org/docid/48abd5980.html

"Report of the High-Level Panel on Threats, Challenges and Change." 2004. http://www.un.org/secureworld/.

. "Report of the Secretary-General on Implementing the Responsibility to Protect." January 12, 2009.

http://www.un.org/en/ga/search/view_doc.asp?symbol=A/63/677.

. "Reports of the Secretary-General on the Sudan." 20 March 2009. http://www.securitycouncilreport.org/atf/cf/\%7B65BFCF9B-6D27-4E9C8CD3-CF6E4FF96FF9\%7D/Sudan\%20S\%20PV\%206096.pdf.

"Security Council Meeting on Peace and Security in Africa." June 23, 2008. http://www.un.org/en/ga/search/view_doc.asp?symbol=S/PV.5921

—_. "Security Council Meeting on Peace and Security in Africa." July 8, 2008. http://www.un.org/en/ga/search/view_doc.asp?symbol=S/PV.5929

. "Security Council Meeting on Protection of Civilians in Armed Conflict." May 27, 2008.

http://www.un.org/en/ga/search/view_doc.asp?symbol=S/PV.5781(Resum ption1)

- "Security Council Meeting on Protection of Civilians in Armed Conflict." November 20, 2007.

http://www.un.org/en/ga/search/view_doc.asp?symbol=S/PV.5781(Resum ption1)

. "Security Council Meeting on the Situation in Sierra Leone." July 16, 2009. http://www.un.org/en/ga/search/view_doc.asp?symbol=S/PV.6136.

. "Security Council Resolution 1889" October 5, 2009.

http://www.un.org/ga/search/view_doc.asp?symbol=S/RES/1889.

_. "Security Council's Meeting on Peace and Security in Africa." July 11, 2008. http://www.un.org/en/ga/search/view_doc.asp?symbol=S/PV.5933 
. "Statement by H.E Mr. Nguyen Dy Nien, Minister of Foreign Affairs of the Socialist Republic of Vietnam to the 60th Session of the United Nations General Assembly." September 21, 2005.

http://www.un.org/webcast/ga/60/statements/viet050921eng.pdf.

_. "Statement by the President of the Security Council." July 17, 2008. http://www.un.org/ga/search/view_doc.asp?symbol=S/PRST/2008/28.

. "Statement by the President of the Security Council." June 23, 2008. http://www.un.org/en/ga/search/view_doc.asp?symbol=S/PRST/2008/23

. "World Summit Outcome Document." 2005.

http://www.un.org/summit2005/documents.html.

Nguyễn, Nhâm. "Lạm dụng trách nhiệm bảo vệ: Lợi bất cập hại" [Abuse of the Responsibility to Protect and Its Implications]. Báo Điện tử Đảng Cộng sản Việt Nam. June 22, 2011, http://dangcongsan.vn/cpv/Modules/News_English/News_Detail_E.aspx? CN_ID=465218\&CO_ID=30671

Nguyễn, Thị Thanh Hà. "Sự khác nhau giữa trách nhiệm bảo vệ và can thiệp nhân đạo" [the Differences between the Responsibility to Protect and Humanitarian Intervention]. Thế giới và Việt Nam. September 12, 2009. http://www.tgvn.com.vn/printContent.aspx?ID=7476

The International Coalition for the Responsibility to Protect. "Report on the General Assembly Plenary Debate on the Responsibility to Protect." September 25, 2012, http://www.responsibilitytoprotect.org/ICRtoP\%20ReportGeneral_Assembly_Debate_on_the_Responsibility_to_Protect\%20FINAL \%209_22_09.pdf.

."Crisis in Zimbabwe." Accessed October 12, 2012. http://www.responsibilitytoprotect.org.

. "Statement by H.E. Ambassador Maged A. Abdelaziz Permanent Representative of Egypt on Behalf of the Non-Aligned Movement on Report of the Secretary-General." July 23, 2009. http://responsibilitytoprotect.org/NAM_Egypt_ENG(1).pdf.

The International Commission on Intervention and State Sovereignty. "The Responsibility to Protect." December 2001. http://responsibilitytoprotect.org/ICISS\%20Report.pdf. 
Communist Party of Vietnam. "Documents of the Eleventh National Congress of the Communist Party of Vietnam." 2011. http://chinhphu.vn.

. "Documents of the Ninth National Congress of the Communist Party of Vietnam." 2001. hhtp://chinhphu.vn.

. "Documents of the Tenth National Congress of the Communist Party of Vietnam." 2006. http://chinhphu.vn.

The Vietnamese Government. "Vietnam - Japan Relations." Accessed April 12, 2014.

http://chinhphu.vn/portal/page/portal/chinhphu/NuocCHXHCNVietNam/C hiTietVeQuocGia?diplomacyNationId=267\&diplomacyZoneId=85\&vietn $\mathrm{am}=0$.

US Department of State. "Remarks by Secretary Clinton." July 23, 2010.

http://www.state.gov/secretary/rm/2010/07/145095.htm.

Embassy of the United States. "Chronology of key Events in U.S. - Vietnam Relations." Accessed April 12, 2014 http://www.usvtc.org/usvietnam/Chronology/Chronology\%20of\%20US-

VN\%20Relations\%2022May08.pdf.

Asia Economic Institute. "Japan Resumes ODA to Vietnam." Accessed April 12, 2014, http://www.asiaecon.org/special_articles/read_sp/12808. 
